UNIVERSIDADE DE SÃO PAULO

Programa de Pós Graduação em Ciência Ambiental

PARADIGMAS DO DESENVOLVIMENTO RURAL EM QUESTÃO DO AGRÁRIO AO TERRITORIAL

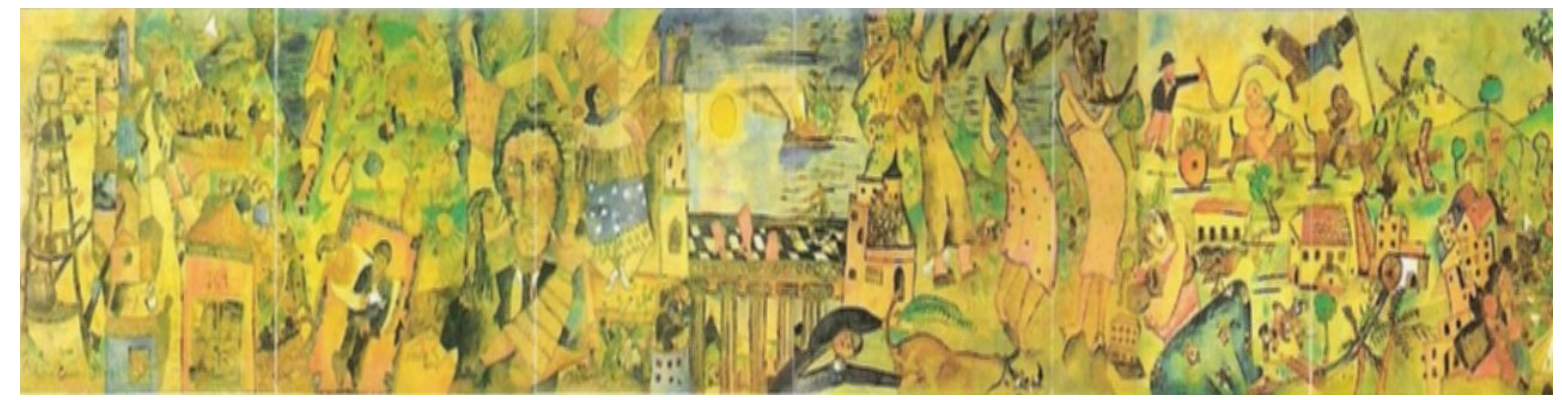

Arilson da Silva Favareto

SÃO PAULO

2006 
Programa de Pós Graduação em Ciência Ambiental

\section{PARADIGMAS DO DESENVOLVIMENTO RURAL EM QUESTÃO - DO AGRÁRIO AO TERRITORIAL}

\section{Arilson da Silva Favareto}

Tese apresentada ao Programa de PósGraduação em Ciência Ambiental da Universidade de São Paulo como exigência parcial para a obtenção do título de Doutor em Ciência Ambiental.

Orientação: Prof. Dr. José Eli da Veiga (Procam e Departamento de Economia da FEA/USP)

\section{SÃO PAULO}

2006 
Este trabalho é dedicado, com muito carinho,

à Dona Rose e ao Seo Ariovaldo, meus pais, e à memória daquela figura tão especial que foi a Dona Aurora 


\section{Agradecimentos}

Uma tese de doutorado é considerada um trabalho de co-autoria entre o aluno e o orientador. Por isso, mas principalmente por sua importância de fato nesta empreitada, devo agradecer inicialmente ao Prof. José Eli da Veiga. Desde as idéias iniciais que viriam a dar origem ao projeto de pesquisa pude contar com sua animadora acolhida. E durante os quatro anos que desde então decorreram pude desfrutar de um intenso e verdadeiro aprendizado. Sou-lhe extremamente grato pela presença constante em todas as etapas e por sua generosa e tão precisa dedicação à orientação.

Durante este período tive também o privilégio de conviver com o Prof. Ricardo Abramovay, interlocutor e encorajador desta pesquisa desde os primeiros esboços. Suas observações no exame de qualificação e em inúmeras oportunidades onde pudemos discutir temas direta ou indiretamente relacionados à tese me foram de extrema valia.

Com o Prof. Afrânio Garcia tive o prazer de partilhar minha estadia na França, na École des Hautes Études em Sciences Sociales. Sou muito grato a ele tanto por ter viabilizado as condições que permitiram meu vínculo com aquela instituição como pelas várias horas que pude desfrutar de agradáveis conversas e, sobretudo, de profícuas críticas e sugestões à minha pesquisa. Também nesta ocasião tive ainda a felicidade de discutir os contornos desta tese com o Prof. Ignacy Sachs, da mesma EHESS, e com Marie France Garcia-Parpet, no Institut National de la Recherche Agronomique.

O Prof. Eduardo Kugelmas, membro da banca no exame de qualificação, ajudou-me bastante com suas observações e com valiosas indicações bibliográficas. Luis Carlos Beduschi, da FAO, e Estela Neves, do CPDA e Colegio de Mexico, foram extremamente gentis e prontamente atenderam meu pedido de envio de materiais relativos ao Chile e ao México. Sou grato ainda à Vera Schattan, por nossa ainda recente mas instigante interlocução sobre os temas relativos à participação e desenvolvimento, no Cebrap. 
Institucionalmente devo agradecer à Capes pelo apoio à realização da pesquisa. Ao Procam, em cujos colegas, professores e funcionários encontrei sempre uma convivência amigável e um ambiente propício às trocas científicas. E aos coordenadores e colegas dos grupos de trabalho de encontros científicos - Anpocs, Anppas, Sober, SBS - onde apresentei partes dos textos que conformam esta tese e que certamente foram enriquecidos com suas contribuições.

Aos colegas do Procam e da Plural, Reynaldo Romagnoli, Lílian Rahal, Paulo Brancher, Maria Célia Souza, Gerson Bittencourt, Eduardo Ehlers, Karin Vecchiatti, Rogério Jorge e Cristina Azevedo meu muito obrigado pela convivência pessoal e profissional nestes anos. Reginaldo Magalhães, Diogo Demarco, Eduardo Britto e Ariane Favareto, além da amizade e companheirismo, me presentearam ainda com atenciosas leituras e críticas aos originais desta tese.

Por fim, como brincou um colega certa vez, entre outros fatores pelo tempo e pela intensidade da dedicação, uma tese poderia ser considerada uma espécie de fato social total. Nos vários domínios que isto comporta sou grato à Graziela Perosa, por nossas trocas afetivas e intelectuais tão especiais. Luca e Isabel, que praticamente nasceram e cresceram com esta tese, não só encararam numa boa o inverno europeu como ajudaram a tornar o período de redação mais saudável com seus constantes pedidos para brincar e contar histórias. Aos dois, um grande beijo ! 


\title{
Resumo
}

O objetivo desta pesquisa é estabelecer a diferença conceitual trazida com a abordagem territorial do desenvolvimento rural em relação às abordagens tradicionais de apreensão deste mesmo objeto nas ciências sociais, a partir de uma análise histórica e teórica do problema. $\mathrm{Na}$ base da emergência do que se convencionou chamar por "nova ruralidade" há um deslizamento no conteúdo social e na qualidade da articulação das suas três dimensões definidoras fundamentais: as relações rural-urbano, a proximidade com a natureza, e os laços interpessoais. A tese que se pretende demonstrar é que os significados maiores desta mudança são, de um lado, a erosão do paradigma agrário que sustentou as visões predominantes sobre o rural ao longo de todo o último século, e, de outro, a intensificação de um longo e heterogêneo processo de racionalização da vida rural. Um processo através do qual o rural, em vez de desaparecer, se integra por completo à dinâmica mais ampla dos processos de desenvolvimento, por meio tanto da unificação dos diferentes mercados (de trabalho, de produtos e serviços, e de bens simbólicos) como também por meio da criação de instituições que regulam as formas de uso social destes espaços, agora amalgamando interesses que têm por portadores sociais segmentos originários também de outras esferas.

\begin{abstract}
The purpose of this research is to establish the conceptual difference embedded in the territorial approach to rural development in relation to traditional approaches to apprehending the same object in social science, founded on a historical and theoretical analysis of the problem. At the basis of the emergence of what convention termed as "new rurality", there is a shift in the social content of and in the quality of the interrelation between its three fundamental defining dimensions: rural-urban relations, proximity to nature, and interpersonal ties. The thesis we intend to demonstrate is that the broader implications of this change are, for one, the erosion of the agrarian paradigm that supported the prevailing visions about the rural throughout the last century and, for another, the intensification of a long and heterogeneous process of rationalization of rural life. A process in which the rural, rather than disappearing, is completely integrated to the broader dynamic of development processes both by means of the unification of the different markets (labor, products and services, and symbolic goods) and the creation of institutions that regulate the forms of social use of these spaces, now amalgamating interests borne by social segments also originating in other spheres.
\end{abstract}




\section{Lista de figuras, quadros e tabelas}

Figura da capa - "Eu vi o mundo... ele começa no Recife", Reprodução do painel de Cícero Dias

Quadro 1 - Práticas agrícolas e surgimento das cidades: comparação temporal e espacial Quadro 2 - Consenso básico sobre a ruralidade avançada

Tabela 1 - População rural nos países da OCDE

Tabela 2 - Distribuição do emprego por setores econômicos nos países da OCDE

Desenho 1 - Representação esquemática do sistema de oposições da ruralidade pretérita

Desenho 2 - Representação esquemática do sistema de oposições da nova ruralidade 


\section{Sumário}

INTRODUÇÃO

\section{PARTE I - DESENVOLVIMENTO}

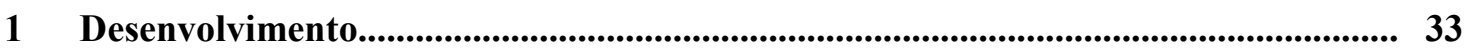

1.1 - A longa trajetória das idéias sobre desenvolvimento......................................... 35

1.1.1 - Da gênese ao evolucionismo................................................................... 35

1.1.2 - Da evolução ao crescimento........................................................ 41

1.1.3 - Crise, polissemia, banalização...ciência...................................................... 46

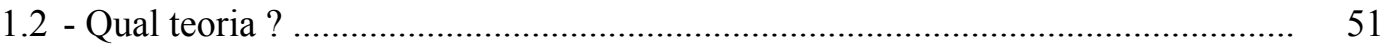

1.2.1 - Desenvolvimento e crescimento econômico............................................. 51

1.2.2 - Desenvolvimento e a questão social....................................................... 61

1.2.3 - Desenvolvimento e meio-ambiente.......................................................... 67

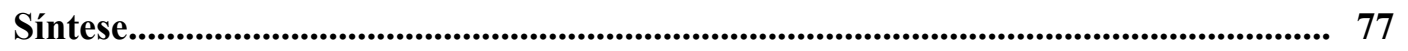

\section{PARTE II - RURALIDADE}

2 Ruralidade.

2.1 - Pequena história da relação rural-urbano........................................................... 80

2.1.1 - Dos primórdios da divisão espacial do trabalho à modernidade.................. 83

2.1.2 - Da industrialização aos tempos atuais.................................................... 87

2.1.3 - A peculiaridade latinoamericana................................................................ 91

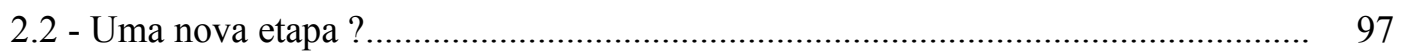

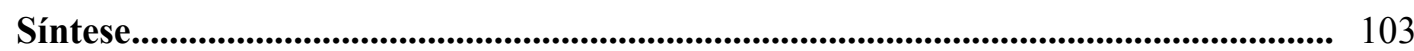

3 Ruralidade nos países do capitalismo avançado................................................................ 104

3.1 - As definições sobre o que é o rural..................................................................... 105

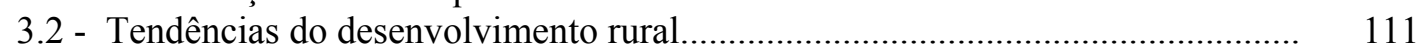

3.2 - As Razões do desenvolvimento......................................................................... 115

3.2.1 - Lições dos programas de pesquisa.......................................................... 115

3.2.2 - Lições dos programas de apoio e promoção do desenvolvimento rural.... 121

3.3 - A emergência da abordagem territorial e seus significados................................ 123

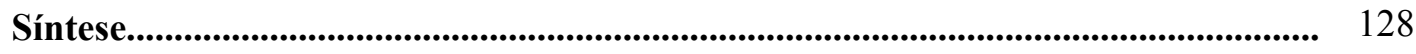


PARTE III - DESENVOLVIMENTO RURAL E MUDANÇA INSTITUCIONAL

4 Os caminhos da disseminação da abordagem territorial.............................................. 130

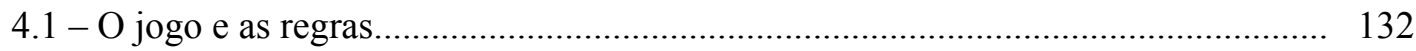

4.1 1- A "nova visão" do desenvolvimento rural............................................ 133

4.1.2 - Da "visão" à ação...................................................................................... 140

4.2 - Um novo compromisso institucional ?............................................................. 155

Síntese

PARTE IV - A RACIONALIZAÇÃO DA VIDA RURAL

$5 \quad$ A racionalização da vida rural............................................................................................. 159

5.1 - Crítica à visão agrária dos territórios rurais....................................................... 162

5.2 - Racionalização da vida rural ............................................................................ $\quad 170$

5.2.1 - O desencantamento dos campos

(ou racionalização e vida cotidiana)......................................................... 174

5.2.2 - Da regulação total, à regulação setorial, e desta à regulação territorial (ou racionalização e instituições).............................................................. 178

5.2.3 - Quem são os agentes da nova ruralidade?

(ou racionalização e estruturas sociais)........................................................ 180

Síntese

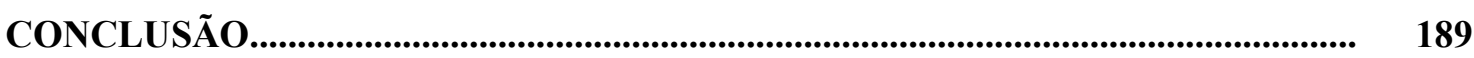

BIBLIOGRAFIA 


\section{Introdução}

"É preciso, antes de tudo,

fazer o catálogo mais amplo possivel de categorias.

É preciso partir de todas aquelas das quais

se pode saber que os homens se serviram.

Ver-se-á então que ainda há muitas luas mortas, ou pálidas, ou obscuras, no firmamento da razão"

Marcel Mauss

As palavras de Marcel Mauss que servem de epígrafe a esta Introdução, e que segundo LéviStrauss deveriam constar no frontispício de toda instituição dedicada à pesquisa social, caminham para um século desde que foram proferidas ${ }^{1}$. De lá até os tempos atuais, a ciência em geral e seus vários ramos em particular alcançaram estágios muito mais avançados, tanto em sua institucionalização, como na elaboração de mais e melhores instrumentos de análise categorias e conceitos, corpos teóricos, métodos e técnicas. Mas, uma das condições para a eficiência das idéias científicas é que estas formas de compreensão e explicação do real estejam sendo permanentemente aperfeiçoadas, justamente para poder acompanhar sua constante evolução. Desde que se assuma que o tempo é uma variável chave na determinação de qualquer fenômeno, seja na natureza ou na sociedade, não há como deixar de lado uma espécie de eterna vigilância quanto à possível obsolescência ou inadequação de noções, perguntas, ou formas de classificação utilizadas pelas várias disciplinas. Basta lembrar que as principais revoluções científicas de nossos tempos (Kuhn, 1962/1987) - por exemplo, o que a teoria de Darwin representou para a biologia, a de Marx para a filosofia e as ciências sociais, a de Freud para a psicologia, a de Einstein para a física - têm, todas, em torno de cento e cinqüenta anos ou menos. E, em todos os casos, seus desdobramentos posteriores - as tentativas de comprovação, melhoria ou refutação de tais teses e enunciados - têm sido igualmente fecundos e, com isso, mudado o patamar de validação e renovação teórica. Talvez seja este caráter vivo, porque determinado pela dinâmica empreendida pela constante evolução do real e das tentativas de sua apreensão, o que Thomas Kuhn melhor destaca em sua conhecida polêmica com Karl Popper. A validade das idéias científicas não resulta

\footnotetext{
${ }^{1}$ Cf. Lévi-Strauss (1950/2003).
} 
somente do movimento cumulativo derivado de seu teste e aperfeiçoamento lógico e prático, mas também, e talvez sobretudo, das visões que presidem o olhar dos pesquisadores e dos processos sociais, internos e externos aos domínios do campo científico. Visões que condicionam os lugares estabelecidos das idéias e também de seus portadores, ou a totalidade na qual elas se inserem, para usar os termos de Adorno $^{2}$. Pôr em marcha o exame de categorias específicas do pensamento científico não deveria ser, portanto, somente uma tarefa epistemológica, mas também histórica e sociológica.

Este é o pressuposto que está na base de toda a tradição da sociologia da ciência, desde Merton. Uma análise da idéia de desenvolvimento rural - objeto desta tese - deveria, assim, se inspirar não somente em sua evolução como conceito, mas também, e principalmente, na busca da compreensão de suas articulações com outros domínios do mundo social, que lhe envolvem e condicionam em alguma medida. Em Merton (1996), estes conteúdos repousam em caracteres internos à comunidade dos cientistas, marcadamente na lógica e nas relações que perfazem o processo de institucionalização de uma disciplina ou idéia científica e a especialização que lhe é correspondente. Embora haja este componente sociológico por detrás da evolução das idéias - a estruturação das comunidades científicas -, nesta linha de estudos os condicionantes estão ainda dentro dos muros do campo científico. É justamente a extrema permeabilidade deste muro e, pois, a altíssima suscetibilidade das idéias científicas ao mundo exterior o que se destaca nos estudos da chamada sociologia das ciências e das técnicas, lideradas por sociólogos franceses como Bruno Latour e Michel Callon. Um dos principais méritos dos estudiosos filiados a esta segunda onda dos estudos de sociologia da ciência é justamente mostrar que, mesmo na mais elaborada e racionalizada das formas de pensamento, há um componente de crença $^{3}$. E, como em toda crença, sua sustentação é fundada em elementos de persuasão que remetem a estratégias de convencimento e disputa encerradas pelos seus diversos agentes, numa dinâmica que muitas vezes conta mais para a evolução científica do que propriamente a cumulatividade dos seus progressos lógicos e técnicos, como destacado pelos epistemólogos clássicos.

\footnotetext{
${ }^{2}$ Os termos desta polêmica estão nos conhecidos textos de Popper (1959/1993; 1978; 1965/1987) e Kuhn (1962/1987; 1965/1979; 1970) e, também em Adorno (1974/1999).

${ }^{3} \mathrm{Na}$ literatura sobre desenvolvimento há vários autores em que a idéia de crença tem algum poder explicativo. $\mathrm{Na}$ maioria deles no sentido negativo ou vulgar do termo, quase associado à ilusão. Um tratamento positivo, que procura explorar as relações cognitivas entre mitos e crenças e processos de desenvolvimento está presente de maneira muito instigante na obra de Celso Furtado. Estes aspectos serão retomados mais detidamente no Capítulo 1. Sobre a sociologia das ciências e das técnicas, ver, entre outros, Latour (1999).
} 
O estudo apresentado nas páginas a seguir tem a pretensão de se inspirar neste tipo de enfoque ao tomar para análise o paradigma que orienta as leituras sobre desenvolvimento rural. A abordagem que será aqui adotada situa-se entre dois extremos - entre a cientificização absoluta da idéia de desenvolvimento e sua redução a mera crença das sociedades ocidentais. Pretende-se mostrar aqui - e essa parece ser a perspectiva ausente tanto dos estudos mertonianos como da sociologia das ciências e das técnicas - que, embora a evolução das idéias científicas não seja somente resultado da dinâmica interna do campo científico, não é possível igualar seu estatuto a uma forma qualquer de crença ${ }^{4}$. A evolução de uma idéia científica é resultado de uma dupla determinação: de um lado incide sobre sua trajetória a posição propriamente social de tais idéias, o lugar que elas ocupam na legitimação de discursos, na polarização de conflitos sociais, na sua aceitação e uso por distintos grupos de agentes internos e externos ao campo científico; de outro, pesa a dinâmica interna deste campo, onde a evolução das idéias se determina tanto pelo movimento dos acúmulos (e dos saltos) teóricos e empíricos construídos segundo os cânones da comunidade científica, como pelas injunções promovidas pelos cientistas entre si, suas disputas e alianças, suas estratégias de afirmação individual ou como grupos de pesquisa ou como correntes teóricas; ou ainda, na conformação e consolidação dos sub-campos disciplinares (Bourdieu, 2000). Em uma palavra, há uma busca por esta dupla natureza e articulação das idéias científicas: elas são a um só tempo produto de uma crença, mas também produtoras de uma crença diferenciada das demais formas de acreditar, à medida que se apoia em critérios de validação mais aceitos socialmente.

Antes de mais nada, para evitar confusões, é preciso deixar bem claro o sentido em que o termo paradigma estará sendo doravante utilizado. E isto é importante não só porque há um corrente abuso derivado da enorme vulgarização desta noção, mas porque seu próprio formulador reconheceu ter usado a palavra em nada menos que vinte e dois sentidos diferentes em seu tão citado livro (Kuhn, 1970: 181). Apesar disso, diz o autor, após uma criteriosa revisão eles poderiam ser reduzidos a apenas dois. O primeiro é chamado por ele de "matriz disciplinar": um corpo coeso formado por "paradigmas, partes de paradigma e paradigmatics". Não será este o sentido aqui adotado. A razão é o caráter fugidio de tal

\footnotetext{
${ }^{4}$ É bem possível que partidários do pensamento de Latour e Callon não concordem com tal afirmativa. A crítica aqui implícita não é que seu esquema teórico leva a alguma forma de relativismo, mas sim que ele não fornece elementos que permitam traduzir em termos teóricos as diferenças que contam para a especificidade do campo científico.
} 
definição. Ela torna-se pouco operacional quando se trata de lidar com idéias científicas que muitas vezes envolvem ora uma composição, ora rupturas parciais, com determinadas explicações dominantes. Como no exemplo dado por Veiga (2000) para o caso da economia: como distinguir se Marx e Schumpetter, por exemplo, podem ser situados dentro de um mesmo paradigma ou se criaram diferentes paradigmas ? No caso da idéia de desenvolvimento rural, os que consideram que há uma crescente integração de mercados estão num paradigma diferente daqueles que sublinham as permanências da tradição, do conflito agrário ou de suas heranças ? O segundo sentido dado por Kuhn é chamado de "exemplos compartilhados": são os entendimentos que permitem o estabelecimento de uma linguagem e uma abordagem comuns para problemas similares. Esta definição é particularmente útil, por chamar a atenção para as idéias científicas como uma espécie de cristalização de posições a um só tempo sociais e cognitivas; isto é, como algo que se apresenta como uma visão partilhada e validada segundo os códigos cientificamente - e poder-se-ia acrescentar também, socialmente - reconhecidos como legítimos para definição e tratamento de um determinado objeto.

Neste caso, a visão partilhada que se tem sobre o que são os espaços rurais e sobre as leis de seu desenvolvimento igualmente funcionam como um organizador de práticas. Ela determina um campo de estudos, o qual circunscreve por adequação ou inadequação uma série de perguntas e práticas pertinentes: Quem são os agentes envolvidos nos processos abordados por estudos rurais ? Os agricultores, as populações das pequenas cidades, com que recorte ? Ela legitima ainda o reconhecimento social sobre a extensão de um determinado espaço e seu lugar social: Fazer parte de regiões metropolitanas não é critério para receber certos tipos de investimentos, em geral políticas de modernização, investimentos em conservação ambiental, integração de infra-estrutura e de serviços públicos, geração de empregos ? Fazer parte de regiões rurais não tem o mesmo papel para outros tipos de investimentos, em geral políticas sociais, incentivos à exploração agrícola, infra-estrutura básica ? E, por último, mas igualmente importante, um paradigma tende a consolidar posições em torno dele. Há uma tendência para que um paradigma se sustente à medida que ele suporta especialidades e seus mecanismos - ramos disciplinares, revistas e publicações, encontros científicos, consultorias técnicas, o monopólio da legitimidade para poder falar sobre certa unidade do mundo social ou natural. 
Por tudo isso, para uma introdução ao que virá, talvez nada seja melhor do que situar o campo de interesses desta pesquisa na evolução dos estudos recentes sobre 0 desenvolvimento rural brasileiro. Cabe tentar minimamente entender também este estudo como mais um resultado da mesma evolução da qual ele tenta dar conta.

\section{Os estudos sobre o rural brasileiro nos anos noventa e o campo de interesses desta pesquisa}

Não é mero acaso ou pura falta de criatividade o paralelo entre o título desta tese e o do livro de Ricardo Abramovay - Paradigmas do capitalismo agrário em questão -, lançado em 1992. Aquele trabalho, juntamente com o publicado no ano anterior, por José Eli da Veiga O desenvolvimento agrícola: uma visão histórica -, e com os dois volumes da comparação internacional organizada por Hugues Lamarche - A agricultura familiar, da qual participaram quatro equipes de pesquisa, uma delas composta pelos pesquisadores brasileiros Nazareth Wanderley, Fernando Lourenço, Anita Brumer, Ghislaine Duque - , estes já nos anos seguintes, formaram juntos uma espécie de trinca incontornável de estudos rurais e serviram para afirmar a relevância da noção "agricultura familiar" para o vocabulário acadêmico brasileiro $^{5}$. Através dos livros de Abramovay e Veiga via-se como a configuração da moderna agricultura capitalista se apoiou numa forma social de trabalho e empresa específica que é a empresa familiar, contrariando assim duas tradições científicas e políticas muito fortes: a que sempre preconizou que o desenvolvimento generalizaria as unidades produtivas baseadas no uso exclusivo ou predominante de mão-de-obra assalariada, e também a que, inversamente, via a agricultura camponesa como modelo. Os livros de Lamarche, por sua vez, mostraram as variantes desta direção. Isto é, tomaram por foco uma série de realidades distintas, em diferentes países, com o intuito de mostrar como, sob a lógica familiar de produção, podem se organizar situações que variam num esquema que tipifica desde aquelas unidades mais próximas da situação de autonomia camponesa até aquelas plenamente inseridas em mercados, mas sempre tendo a lógica familiar como elemento organizador. Enquanto Veiga demonstrou a articulação entre estas formas familiares e o desenvolvimento do capitalismo avançado, Abramovay tomou a realidade destes mesmos países para proceder à distinção conceitual entre o significado desta agricultura de base familiar e da agricultura camponesa. E Lamarche, por sua vez, deixou claro que a diversidade não esconde o fato de que o elemento

${ }^{5}$ Cf. Veiga (1991), Abramovay (1992), Lamarche (1993; 1998). Para uma análise das razões da ascensão da idéia de agricultura familiar no debate público brasileiro dos anos noventa ver Schneider et al. (2004), Favareto (2005-b). Os anais da Apipsa trazem um farto material sobre o tratamento do tema na década anterior. 
unificador de uma variedade de situações é o caráter familiar da gestão e da posse da terra, reforçando o argumento de que não faria sentido resumir a diversidade da agricultura familiar às condições que mais se aproximam da idéia clássica de campesinato.

Estas obras procediam, assim, a uma espécie de atualização dos quadros cognitivos face à evolução experimentada pela dinâmica do desenvolvimento agrícola desde o Pós-guerra até a consolidação da chamada "modernização conservadora"'. As novas idéias por elas trazidas tiveram reflexos profundos e imediatos não só sobre o campo propriamente acadêmico, como também sobre o discurso de movimentos sociais e da burocracia governamental ligada à agricultura, e foram acompanhadas por movimentos correspondentes de igualmente significativa repercussão. Um conhecido artigo de Kageyama \& Bergamasco (1990) já havia alcançado amplo destaque ao fornecer uma aproximação sobre o tamanho do universo de estabelecimentos familiares no Brasil. Pouco depois foi publicado o instigante e controverso relatório FAO/Incra (1994), que também ofereceu uma tipologia das formas sociais de produção no meio rural brasileiro, a qual viria a ser adotada, dois anos depois, como uma das bases do Pronaf - o Programa Nacional de Fortalecimento da Agricultura Familiar ${ }^{7}$. Neste mesmo momento, os sindicatos de trabalhadores e suas estruturas nacionais estavam simplesmente substituindo suas bandeiras de luta empunhadas há nada menos do que trinta anos - reforma agrária e direitos trabalhistas - pela reivindicação por um "projeto alternativo de desenvolvimento rural baseado na agricultura familiar"».

Entre 1996 e 1998, uma pesquisa cobrindo todo o território nacional, realizada a pedido das organizações sindicais de representação da agricultura familiar e patrocinada com recursos de instituições européias de cooperação tentou mapear as dinâmicas àquele momento qualificadas como meso-regionais de desenvolvimento existentes no Brasil. O intuito inicial era identificar a dispersão geográfica das formas familiares e patronais, a maior ou menor

\footnotetext{
${ }^{6}$ Um traço extremamente importante nesta passagem, mas que não pode ser explorado nos limites desta Introdução, diz respeito à maneira como estes estudos combinaram as influências da tradição brasileira de interpretação do conflito agrário e a literatura norte-americana e européia. Evidentemente a introdução da noção agricultura familiar para o repertório acadêmico brasileiro não ocorreu sem críticas, como por exemplo, aquela feita em Garcia Jr \& Gryzpan (2002). Igualmente esclarecedoras são a crítica e a réplica de Germer (1996) e Abramovay (1996). Sobre o mesmo debate, é preciso ainda citar o importante artigo de Wanderley (1998).

${ }^{7}$ Para uma crítica desta tipologia e de seu uso no planejamento de políticas públicas ver Carneiro (1998). Sobre o significado institucional da criação do Pronaf, ver Abramovay \& Veiga (1998).

${ }^{8}$ Para um panorama mais detalhado das interdependências entre os campos acadêmico, sindical e as políticas de desenvolvimento do Brasil rural, ver entre outros Medeiros (1997), Schneider, Mattei \& Cazzella (2004) e Favareto (2004-a, 2005-b).
} 
incidência de certos produtos agropecuários e, com isso, subsidiar minimamente a atuação destes organismos sindicais (Projeto CUT/Contag, 1998). Coordenada por José Eli da Veiga, esta pesquisa não só atingiu este intento inicial como avançou uma hipótese bastante inovadora à época ${ }^{9}$ : as melhores configurações territoriais encontradas eram aquelas que combinavam uma agricultura de base familiar forte com um entorno sócio-econômico diversificado e dotado de infra-estrutura; um desenho que permitia aos espaços urbanos e rurais destas regiões, de um lado, abrigar o trabalho excedente que deixa a atividade agrícola e, de outro, inversamente, absorver nas unidades familiares o trabalho que é descartado nas cidades em decorrência do avanço tecnológico e do correspondente desemprego característico dos anos 90. Esta pesquisa mostrou um campo novo de preocupações que viria a se delinear melhor, no Brasil, na virada para a década atual: a necessidade de se entender as articulações entre formas de produção, características morfológicas dos tecidos sociais locais e dinâmicas territoriais de desenvolvimento; ou, na mesma direção, as articulações entre os espaços considerados rurais e urbanos. Mais do que nas injunções setoriais, o que se sugeria é que nas dinâmicas territoriais - ainda sem usar esta denominação - é que se poderia encontrar as respostas para as causas do dinamismo e da incidência de bons indicadores de desenvolvimento.

Pouco depois de terminada a pesquisa CUT/Contag, inicia-se um outro programa com grande repercussão: o Projeto Rurbano. Coordenado por José Graziano da Silva, este programa focalizou a formação das rendas entre as famílias não urbanas para constatar um movimento relativamente generalizado de substituição dos ingressos provenientes das atividades primárias por rendas não-agrícolas. $\mathrm{Na}$ base desta constatação estavam não somente a tendência de queda dos preços de produtos primários, já conhecida, mas principalmente a crescente interpenetração entre os mercados de trabalho tradicionalmente qualificados como urbanos e rurais (Graziano da Silva, 1999). Entre o primeiro o terceiro dos seminários anuais realizados pelo Projeto Rurbano houve, contudo, um certo deslizamento, da surpresa com os resultados alcançados na análise dos dados que mostraram a magnitude das rendas não agrícolas, à fragmentação de opiniões sobre seu real alcance e sobre seus significados para a

\footnotetext{
${ }^{9}$ A rigor esta pesquisa era composta de dois estudos simultâneos e em diálogo. Este primeiro, coordenado por José Eli da Veiga, abordando desenvolvimento rural. E um segundo, coordenado por Regina Novaes e Leonilde Medeiros, sobre sindicalismo rural. Fazia parte da equipe ainda um grupo de pesquisadores das mais destacadas organizações não governamentais brasileiras com atuação sobre o tema.
} 
estrutura e dinâmica do rural brasileiro ${ }^{10}$. Mesmo em meio a estas incertezas, não há dúvida de que o projeto foi uma forte demonstração de que, mesmo num país com as características do Brasil, o rural não pode ser reduzido ao agrícola ${ }^{11}$.

Claro que estes autores e obras não esgotam o rico painel de pesquisas produzidas no país no período. O que ocorre é que, nestes programas, a definição de agricultura familiar e, posteriormente, as conexões entre desenvolvimento rural e dinâmicas territoriais estiveram no centro das preocupações. Outros importantes centros de pesquisa tiveram iguais impactos em distintas ramificações temáticas dos estudos rurais. Para ficar apenas em alguns exemplos, este é o caso dos estudos sobre campesinato e questão agrária no Museu Nacional, dos estudos sobre assentamentos no CPDA/UFRRJ, das pesquisas sobre agricultura familiar e meio-ambiente na UFPR, dos estudos sobre agricultura familiar e democracia e também sobre pluriatividade na UFRGS, ou de toda a produção sobre o semi-árido na Universidade Federal de Campina Grande ${ }^{12}$.

Mesmo com tudo isso, é forçoso constatar que os anos noventa terminam com o debate público e acadêmico sobre agricultura familiar e desenvolvimento rural fortemente marcado pelos impactos de dois destes programas de pesquisa. De um lado, a ênfase na importância e no poder explicativo da agricultura familiar e a identificação das dinâmicas territoriais como unidade de análise relevante para a compreensão dos fenômenos relacionados ao desenvolvimento. De outro, a ênfase no dinamismo dos espaços urbanos e seus desdobramentos na formação das rendas das famílias de agricultores.

Mas, esta nova forma de compreender o rural, explorando suas articulações territoriais e interdependências com o urbano teria como um de seus desdobramentos o esvaziamento de seu conteúdo explicativo? Se sob o ângulo empírico o rural apresenta cada vez mais injunções com o urbano, do ponto-de-vista teórico qual seria então sua validade ?

\footnotetext{
${ }^{10}$ Cf. Projeto Rurbano (2002). Para algumas posições divergentes sobre estes temas no seio da própria equipe de pesquisadores, consultar Schneider (2002) e Carneiro (1998), de um lado, e Graziano da Silva (2001) de outro. No site do projeto há vários textos disponíveis: http://www.eco.unicamp.br/nea/rurbano/rurbanw.html ${ }^{11}$ E não algumas inferências, formuladas a partir desta constatação, apontando um suposto fim das formas familiares de produção e uma identificação das causas explicativas para os fenômenos que denotam alguma vitalidade do mundo rural na força irresistível do dinamismo emanado de economias urbanas, do que se depreenderia não só a irrelevância teórica da agricultura familiar como mesmo de ruralidade (Graziano da Silva, 2001).

${ }^{12}$ Para um painel mais pormenorizado da produção das ciências sociais brasileiras sobre o rural, consultar Garcia Jr \& Gryzpan (2002).
} 
Parece ter sido exatamente esta preocupação que norteou a elaboração de um conhecido artigo de Nazareth Wanderley (2000). Sob o singelo objetivo anunciado de dar visibilidade a uma bibliografia pouco veiculada no Brasil sobre as mudanças dos espaços rurais europeus, a autora introduzia, na verdade, todo o debate sociológico que se fazia naquele momento sobre os significados destas novas dinâmicas econômicas e espaciais. Os autores por ela citados enfatizavam, sob distintas perspectivas teóricas, três tipos principais de processos sociais com implicação para novas significações do rural: o novo lugar da agricultura e do rural nas sociedades dos países do capitalismo avançado, as relações entre o rural e o urbano num contexto de maior mobilidade física dos indivíduos e de aproximação entre as condições de vida nos dois espaços, e as dimensões distintas e conflitivas reveladoras da heterogeneidade do rural contemporâneo. O artigo refletia em termos propriamente teóricos essa cada vez mais perceptível mudança de significado da relação entre o rural e o urbano que aparecia de maneira expressa ou latente nos textos por ela citados. Ao final, o artigo trazia uma constatação e uma pergunta. A constatação: o estreitamento das distâncias e a diluição de muitas das diferenças não apagou a necessidade de distinção positiva entre o que é rural e o que é urbano. A dúvida: diante destas novas significações e de seu caráter marcadamente desigual entre regiões e países, quem são os atores, ou o ator, da "nova ruralidade" ?

Em nova pesquisa coletiva, apoiando-se destacadamente nos recém divulgados dados do Censo de 2000, Veiga et al. (2001) recalculam as dimensões do Brasil rural introduzindo critérios similares àqueles utilizados nos países do capitalismo avançado e chegam a, pelo menos, duas conclusões importantes: não só o Brasil rural é muito maior do que se calcula, como boa parte deste significativo espaço vinha apresentando indícios de dinamismo demográfico que nada deixam a desejar às áreas urbanas mais prósperas. Por se tratar de uma pesquisa realizada em um pequeno intervalo de tempo, não foi possível, apesar de algumas incursões a campo, chegar a uma conclusão sobre os fatores de atração populacional ou de dinamização econômica das regiões estudadas ${ }^{13}$. Mas a repercussão foi suficientemente grande, e juntamente com os textos de Abramovay, em particular aqueles que deram visibilidade à utilização da noção de "capital social"14, contribuiu para que o debate

\footnotetext{
${ }^{13}$ A esse respeito ver Favareto, Magalhães e Bittencourt (2002), onde são relatados os resultados obtidos com as idas a campo em áreas do litoral, do agreste e do sertão do Nordeste brasileiro. Ver também Veiga (2002) onde estão vários artigos do autor apoiados nestes estudos.

${ }^{14}$ Entre os mais citados em estudos e publicações posteriores está Abramovay (1998). Consultar também Abramovay (2003).
} 
envolvendo territorialidade e desenvolvimento rural inaugurasse uma nova onda de trabalhos dedicados ao tema. Em paralelo, desde meados dos anos noventa o Programa Leader vinha instituindo um novo modelo de organização das políticas para o rural europeu, baseado justamente no seu enfoque territorial, em contraponto com o fortíssimo viés setorial da Política Agrícola Comum ${ }^{15}$. Na esteira deste novo momento intelectual, e à luz da experiência européia recente, a idéia de territorialidade alcança o desenho das políticas públicas no Brasil: entre 2001 e 2002 na forma de uma série de debates preparatórios a uma conferência nacional (que, no entanto, não chegou a acontecer); e, posteriormente, em 2003, com a criação de uma Secretaria de Desenvolvimento Territorial no âmbito do Ministério do Desenvolvimento Agrário.

Esta rápida divulgação da idéia de desenvolvimento territorial, contudo, não veio acompanhada de uma proporcional multiplicação de bons estudos, projetos e análises dedicados ao tema. Bem ao contrário, em parte significativa dos casos as idéias de desenvolvimento rural, de capital social e de território aparecem como termos incorporados ao vocabulário de planejadores de políticas e, em alguns casos também de intelectuais, mas sem os devidos cuidados e sem a devida consistência teórica.

Em uma palavra, pode-se dizer, portanto, que a década de noventa iniciou-se sob a marca da entrada da agricultura familiar no vocabulário acadêmico, enquanto a presente década iniciase com uma reavaliação do significado do desenvolvimento rural, que aparece sob a forma do debate sobre as relações entre o rural e o urbano e da introdução da abordagem das dinâmicas territoriais nos processos de desenvolvimento ${ }^{16}$. Se para a novidade dos anos noventa - a introdução da agricultura familiar no debate público e acadêmico - os trabalhos já citados no início desta introdução trouxeram elucidação teórica e histórica, o mesmo ainda não foi feito para as questões em debate na presente década. Por isso, estabelecer a diferença conceitual trazida com a abordagem territorial do desenvolvimento nas áreas rurais em relação às abordagens tradicionais de apreensão deste mesmo universo forjadas nas ciências sociais

\footnotetext{
${ }^{15}$ Uma boa síntese das articulações entre mudanças dos espaços rurais e políticas de desenvolvimento, na Europa e na América Latina pode ser encontrada na publicação originada no Taller Políticas, instrumentos y experiencias de desarrollo rural em America Latina y Europa, coordenado por Edelmira Correa e Jose Maria Sumpsi (Correa \& Sumpsi, 2001).

${ }^{16} \mathrm{O}$ termo utilizado aqui é "retomada" porque tal debate está longe de ser recente. Ver, por exemplo, o Colóquio Villes et Campagnes, realizado na França nos anos 50. Ou, no caso brasileiro, o artigo de Maria Isaura Pereira de Queiroz (1979) e que trata justamente disso. A novidade, como se verá, diz respeito ao estatuto e à qualidade da relação entre estes dois espaços.
} 
tornou-se a principal lacuna a que esta tese se propõe preencher. Daí, portanto, a inspiração do título no livro já clássico de Abramovay.

\section{O problema e as hipóteses}

A emergência da abordagem territorial do desenvolvimento rural trouxe uma dificuldade prática e teórica. A conjugação do adjetivo "territorial" ao substantivo "desenvolvimento" pretende, a um só tempo, envolver e substituir com maior precisão outros qualificativos relacionados à dimensão espacial dos processos de desenvolvimento, como rural, urbano, regional, local. Um movimento que traz implicações relativas tanto aos contornos dos diversos domínios do campo científico e também da divisão técnico-administrativa de estruturas de governo e órgãos de planejamento, como aos quadros mentais de interpretação de leigos e especialistas. Com isso, uma das principais dificuldades que envolvem a idéia de desenvolvimento territorial, e que tem a ver com os caminhos que passam por sua origem e institucionalização, reside no caráter eminentemente normativo que tem marcado a maioria das proposições disponíveis. Como bem destaca Meyer-Stamer (2004), a literatura disponível sobre este tema trata, sobretudo, de policy, de ferramentas aplicadas, e não de politics, de processos políticos reais ou de aparatos teóricos que permitam apreender em bases científicas os fenômenos em questão.

Uma tomada de posição possível diante desta constatação é a simples desqualificação do conteúdo científico da idéia de desenvolvimento rural, devido a sua, por assim dizer, contaminação por determinações exógenas aos limites da epistemologia. A dificuldade que se impõe com esta postura é que, a partir daí, o debate propriamente científico fica interditado. Ele só pode se dar em outro terreno, através da retórica, ou da política. Outra atitude consiste em admitir as interdependências entre o normativo e o analítico e tentar trazer esta mútua determinação para o corpo do estudo. Isto implica mostrar a via de mão dupla que há entre os condicionantes sociais do conhecimento científico e a legitimidade científica emprestada a processos sociais.

O problema ao qual se dedica este estudo pode ser, portanto, traduzido em duas perguntas. A primeira é saber se é possível distinguir o que há de teórico, de científico e o que há de arbitrário na idéia de desenvolvimento territorial. Isto equivale a abordar os sentidos e as 
razões do desenvolvimento, em geral, e do desenvolvimento rural em particular, até chegar à emergência da abordagem territorial no mundo contemporâneo e seus significados. A segunda, consiste em elucidar quais as implicações teóricas desta nova situação. Mais especificamente, importa aprofundar um dos seus vários significados relevantes, aquele que diz respeito à validade e alcance dos paradigmas que sustentaram toda a tradição das ciências sociais aplicadas ao estudo dos fenômenos rurais. Estas duas grandes questões podem ser desmembradas em perguntas mais específicas, através das quais se descortina o caminho investigativo a ser empreendido.

Se a abordagem territorial envolve uma escala ou dimensão específica dos processos de desenvolvimento, é preciso iniciar decantando o que há de científico e de arbitrário sobre as idéias de desenvolvimento e de desenvolvimento rura ${ }^{17}$. Embora seja habitual atribuir a ocorrência de bons indicadores sociais e econômicos de regiões rurais a um fator explicativo, como a localização ou outras vantagens comparativas, a experiência dos países do capitalismo avançado mostra que há, na verdade, uma multiplicidade de fatores concorrenciais, com maior ou menor incidência dependendo do caso em questão. Em geral três são os fatores principais que contribuem para a ocorrência de bons indicadores: o aproveitamento do dinamismo gerado a partir da vitalidade de espaços urbanos próximos, este o mais presente na literatura dedicada ao tema e também compatível com análises mais tradicionais; a incidência de fortes políticas sociais, com destaque para aquelas que implicam a transferência de fundos públicos; e um dinamismo próprio de determinados espaços rurais. Cada um destes três fatores é mais enfatizado por correntes teóricas específicas, sobretudo na economia. Mas nos três casos, contudo, a ocorrência destes fenômenos não poderia ser explicada sem que se recorra à análise dos caracteres próprios dos territórios, sobretudo se a pergunta for algo do tipo "por que isso acontece aqui, e não em outro lugar com condições similares ?". Segundo uma quarta explicação, o que permitiria a determinados espaços captar efeitos de proximidade, transformar em trunfos ao desenvolvimento os investimentos em políticas sociais, ou até mesmo o estabelecimento de uma dinamização endógena de sua base econômica - em resumo, as três explicações correntes - é a existência de instituições locais

\footnotetext{
${ }^{17} \mathrm{O}$ uso do termo "arbitrário", aqui, deve-se a uma insatisfação quanto ao uso da oposição científico-normativo, já que as definições que se enquadram neste segundo pólo muitas vezes se baseiam e se legitimam em proposições originadas do primeiro. Não se trata de negar as diferenças ente o científico e o normativo, mas repita-se, enfatizar as interdependências.
} 
que favoreçam a coesão territorial e o aproveitamento dos recursos locais aproximando taxas privadas e sociais de retorno.

Mas há nesta explicação uma dificuldade e uma insuficiência. A insuficiência está no fato de que ninguém discorda de que é impossível falar em processos de desenvolvimento sem pensar que a dinamização econômica é parte fundamental disso, mas há evidências suficientes para afirmar igualmente que tais processos não se resumem a haver ou não crescimento econômico, que em última análise é do que trata a maior parte das teorias disponíveis. A dificuldade, por sua vez, reside na crítica de que, embora poucos discordem da afirmação de que as instituições importam, e muito, pouco se sabe sobre o que faz com que sejam geradas as instituições capazes de levar a uma convergência dos ganhos individuais e coletivos e sobre como isso acontece ${ }^{18}$.

Por isso esta tese não poderia começar sem uma reflexão sistemática sobre a longa trajetória das idéias sobre desenvolvimento, com o objetivo de destacar os usos políticos, normativos e científicos desta idéia. Ainda nesta mesma parte, é apresentado um reexame das teorias disponíveis e, a partir dele, a composição de um quadro de análise para um estudo sobre a evolução e dinâmica dos espaços rurais. $\mathrm{Na}$ ausência de uma teoria que dê conta das dimensões econômica, social e ambiental, são retomados os principais achados de estudos recentes sobre cada uma delas. O argumento central desta parte do trabalho é que o corpo teórico fornecido pela nova economia institucional pede que a ele sejam agregados aspectos presentes em outras abordagens, sobretudo aqueles relativos ao meio-ambiente e às estruturas sociais dos espaços em análise, particularmente importantes para explicar as razões que respondem pelo surgimento das instituições que governam as ações dos diferentes agrupamentos humanos.

Uma vez decantadas as bases empíricas dos caracteres propriamente científicos presentes na idéia de desenvolvimento, pode-se enfrentar a segunda tarefa, que consiste em aplicar este quadro de análise à realidade específica do universo em questão: os espaços rurais. Como já ensinava Florestan Fernandes há décadas, é preciso, para isso, trilhar um caminho que combina elementos obtidos através da análise sincrônica - o que permite revelar a natureza e a variedade das funções e mecanismos que respondem pela dinâmica dos espaços rurais num

${ }^{18}$ Cf. a crítica, entre outros, de Przeworsky (2003) e Fligstein (2001). 
determinado horizonte de tempo, neste caso nos países do chamado capitalismo avançado no mundo contemporâneo -, e uma análise diacrônica - que leva à percepção das influências mais profundas e persistentes que atuam na preservação ou na alteração do padrão configuracional destes espaços ${ }^{19}$. Os objetivos aqui consistem em, igualmente ao que se terá feito na parte anterior do estudo, identificar o que há de arbitrário e de científico na idéia de desenvolvimento rural. E agora, além disso, interrogar as razões do surgimento da chamada abordagem territorial e seus significados para a tradição explicativa anterior, que está na base das ciências sociais aplicadas aos estudos rurais.

Nesta parte, pretende-se mostrar que a chamada abordagem territorial emerge num contexto sócio-histórico muito específico, revelando-se tanto uma categoria empírica, em cuja base estão as transformações recentes muitas vezes batizadas sob a definição ampla e vaga de "novas ruralidades"20, como uma categoria cognitiva, formulada visando dar conta da dinâmica emanada desta nova situação. A conjunção deste duplo significado contido na idéia de desenvolvimento territorial traz consigo nada menos do que um solapamento das bases históricas e teóricas sobre as quais se construiu toda a tradição dos ramos disciplinares devotados aos estudos rurais ao longo do século passado. Adicionalmente, pretende-se demonstrar também que, menos do que uma nova teoria, a emergência da abordagem territorial implica, sobretudo, no dimensionamento de uma escala específica dos processos de desenvolvimento onde, em vez de uma análise dicotômica do urbano e do rural, torna-se necessário um enfoque relacional, que envolva os dois pólos a partir do entendimento de suas relações de oposição e de complementaridade. Uma escala que necessariamente remete ao conceito de região e que obriga a um seu reexame. Uma escala que sugere a necessidade de reabertura de um diálogo entre as ciências sociais e a ecologia, afastadas em demasia tanto por conta das inegáveis especializações que cada uma comporta, como, talvez principalmente, pela necessidade decorrente do processo de institucionalização disciplinar em sublinhar mais as diferenças do que as complementaridades, algo simplesmente fundamental no caso de objetos onde a presença da natureza é tão marcante como no caso dos estudos rurais. A chamada abordagem territorial do desenvolvimento rural revela, enfim, um conjunto

\footnotetext{
${ }^{19}$ Cf. Fernandes (1959). O "método regressivo-progressivo" de Henri Lefebvre baseia-se em um encadeamento de procedimentos muito similares e é muito bem apresentado por um de seus maiores conhecedores, José de Souza Martins, num livro dedicado ao seu pensamento (Martins, 1996).

${ }^{20}$ Entre as louváveis exceções a este tratamento amorfo ou polissêmico da "nova ruralidade" nas ciências sociais cabe citar, a título de exemplo, os trabalhos de Carneiro (1998), Wanderley (2000), Veiga (2000, 2004, 2005), Abramovay (2003) e Brandenburg (2005)
} 
de instâncias empíricas fundamentais e incontornáveis, uma escala específica dos processos sociais a ela subjacentes e, igualmente importante, a necessidade de se recorrer a teorias sociais e ecológicas que dêem o devido suporte à sua análise.

Todo este conjunto de questões empíricas e conceituais ainda é relativamente recente. Embora o marco de emergência da abordagem territorial, o já conhecido estudo de Arnaldo Bagnasco (1977) - Tre italie: la problematica territoriale dello svillupo italiano ${ }^{21}$-, esteja prestes a completar trinta anos, a repercussão do campo de estudos com ele estabelecido vem atravessando uma lenta e gradual evolução, tendo encontrado nas agências multilaterais e nos órgãos de cooperação internacional um fértil terreno de disseminação. Longe de se tratar de um movimento linear, tal concepção vem sendo reelaborada e retraduzida de acordo com necessidades teóricas ou com experiências históricas e políticas específicas, através das quais suas partes constitutivas vão sendo ora aprimoradas, ora distorcidas, mas sem dúvida alguma modificadas. Esta dinâmica é o objeto da terceira parte do estudo, cujo intuito é analisar um aspecto empírico específico que envolve a idéia de desenvolvimento territorial: a compreensão dos fenômenos de mudança institucional que abarcam, de um lado, a compreensão dos processos sociais que estão em sua base e, de outro, o jogo de interesses que baliza a introdução de tal debate em países da periferia do capitalismo. O que se pretende demonstrar é que os caminhos de disseminação desta abordagem têm propiciado uma espécie de "inovação por adição" no vocabulário, no discurso e nas políticas, tanto de instituições governamentais como de organizações de apoio e movimentos sociais. Através da análise da experiência de alguns países latinoamericanos, pretende-se evidenciar como este movimento revela, na verdade, um fenômeno qualificado por teóricos da economia e da ciência política como "dependência de percurso" (path dependence) ${ }^{22}$. Isto é, a existência de toda uma estrutura de bases cognitivas e interesses traduzidos em incentivos e constrangimentos estabelecidos em consonância com os aspectos mais marcantes da velha visão.

A quarta e última parte do estudo retoma o ponto-de-partida, requalificando-o. À luz dos principais achados das três partes anteriores - do sentido e das bases teóricas de compreensão dos processos de desenvolvimento, da identificação das tendências e significados da

\footnotetext{
${ }^{21}$ O livro de Bagnasco pode não ter sido exatamente o primeiro neste tema, mas certamente foi o que alcançou mais ampla repercussão. Sobre variações do mesmo tema e enfoque, vale citar o trabalho de outros italianos como G. Beccatini, G. Garofoli, S. Brusco, e C. Triglia.

${ }^{22}$ Cf, principalmente North $(1992,2005)$ e Pierson (2004).
} 
ruralidade na experiência histórica e no mundo contemporâneo, e da análise dos interesses e contradições que têm perpassado a percepção e a normatização do discurso acadêmico e político sobre a abordagem territorial - o estudo pretende avançar uma afirmação que serve de corolário à síntese anunciada para cada uma das partes que o compõem e que diz respeito ao significado mais profundo da idéia de desenvolvimento rural.

A tese que será apresentada nas próximas páginas é que a ascensão da abordagem territorial, em cuja base está o desaparecimento do caráter positivo que até recentemente forneceu o argumento para a dicotomia entre o urbano e o rural, representa, na verdade, a intensificação da longa evolução de um processo de racionalização do mundo rural que, nos tempos atuais, o integra por completo à dinâmica mais ampla dos processos de desenvolvimento por meio tanto da unificação de diferentes mercados - o mercado de trabalho e os mercados de produtos e serviços, geralmente enfatizados, mas também o mercado de bens simbólicos antes típicos de universos sociais mais claramente autônomos, o "mundo rural" e o "mundo urbano", como também por meio da criação de instituições que regulam as formas de uso social destes espaços, agora amalgamando interesses que têm por portadores sociais segmentos originários também de outras esferas - como os ambientalistas, ou o que parte da literatura chama por neo-rurais.

Esta mudança, porém, longe de significar o total desaparecimento do rural perante o caráter irresistivelmente atrativo do urbano, traduz-se na emergência de uma nova situação, onde a diferença entre ambos se afirma de uma maneira relacional. A chamada "nova ruralidade", indissociável dos fenômenos privilegiados pela abordagem territorial, se assenta assim sobre uma dupla contradição. Em primeiro lugar, a afirmação definitiva da persistência do rural como categoria pertinente de compreensão de determinados espaços sociais se faz justamente no momento histórico em que ocorre, para utilizar as palavras de Veiga (2005), o mais completo triunfo da urbanidade. Em segundo lugar, esta afirmação do rural como universo específico, situado na fronteira entre sociedade e natureza, passível de ser compreendido positivamente, tem como uma de suas marcas justamente o fato de revelar-se uma esfera de intersecção de outros domínios, com destaque para as esferas ambiental, econômica e política. É esta dupla condição o que dificulta o alcance de boa parte das análises sobre o rural contemporâneo, que ora enfatizam a desagregação de um sistema de oposições que respondia pela estruturação das relações sociais características da ruralidade pretérita, ora 
destacam a persistência de traços desta ruralidade tradicional em meio às vicissitudes de sua exposição às forças da urbanização crescente e dominante. A "nova ruralidade", passível de compreensão e explicação por uma abordagem territorial dos processos de desenvolvimento nestes espaços, tem por marca justamente uma integração entre o rural e o urbano num grau sem antecedentes e com uma nova qualidade. Com isso, as características de isolamento e de oposição, que em muito influenciaram as bases cognitivas do período anterior, perdem sentido. Onde só se enxergava o lugar de realização das atividades primárias, uma lógica econômica intersetorial. Contra as concepções mágicas cercando a relação com a terra e o mundo, a racionalização, expressa tanto em formas de condução ético-cotidiana e de organização da vida por parte das populações rurais, como na criação de instituições que mais e mais interpenetram esta esfera específica do mundo social condicionando o espaço de possíveis em que seu futuro se inscreve.

Assim como o estudo de Abramovay (1992), mostrou mais de uma década atrás a falência dos paradigmas clássicos de interpretação do capitalismo agrário, expressa no título original de sua tese de doutorado - de camponeses a agricultores -, o presente estudo pretende demonstrar movimento análogo, agora tendo por objeto não as formas sociais de produção na agricultura, mas a natureza mesmo destes espaços e de suas tendências contemporâneas, o que poderia ser apresentado, em termos empíricos, com o movimento indicado nas palavras de Pierre Coulomb - do compromisso setorial ao compromisso territorial -; ou, em termos teóricos, com o movimento indicado no sub-título desta tese - do agrário ao territorial. Enquanto na obra de Abramovay os alvos são o marxismo clássico e a vertente chayanoviana de estudos sobre campesinato, criticadas pela impossibilidade lógica de compreensão das formas familiares, no caso do primeiro, e pela diluição histórica da base autônoma destas mesmas formas, no caso do segundo, nesta pesquisa as oposições se dão contra as vertentes nas quais o lugar dos espaços rurais sempre foi o de responder pela produção de bens primários, e de uma maneira onde sua dinâmica restaria meramente subsidiária dos processos sociais e econômicos emanados do mundo urbano, reificado por sua equivocada identificação como locus exclusivo da industrialização, da complexidade e da multiplicação das possibilidades de interação. 


\section{Dois esclarecimentos de ordem teórica e metodológica}

A vastidão da abordagem aqui sugerida certamente representou o mais sério problema para a realização deste estudo, não há dúvida. O conjunto de unidades empíricas a serem manipuladas, a base teórica fundamentada em corpos distintos e provenientes de tradições disciplinares diferentes, o caráter polêmico da tese apresentada, são fatores que tornam a empreitada anunciada uma iniciativa que envolve uma alta dose de risco. No entanto, a manutenção desta proposta foi um desafio consciente e, em certa medida incontornável, se a pretensão é, de fato, a resposta à questão anunciada, cuja importância e pertinência parece ser inegável. Uma possibilidade alternativa de alcançar uma aproximação ao problema colocado seria proceder a um balanço das conceituações disponíveis sobre desenvolvimento territorial e, a partir delas, inferir os significados implícitos à sua elaboração. Este caminho foi descartado por duas razões: o fato de que boa parte desta literatura se assenta sobre bases eminentemente normativas, como já foi destacado anteriormente, e a restrição de um tal enfoque somente ao aspecto cognitivo presente no debate sobre desenvolvimento territorial. A leitura de Norbert Elias (1970/1991) e seu alerta quanto à importância das abordagens de longo prazo, ultimamente pouco valorizadas no campo acadêmico, ao lado dos recentes artigos de José Eli da Veiga (2005), baseados naquilo que ele chama de hipótese macrohistórica, forneceram o impulso que faltava para que o projeto ambicioso (pretensioso até, talvez), fosse aceito. Isto, contudo, não foi feito sem ressalvas ou cuidados. Sem isso a abertura da abordagem fatalmente se converteria em força centrífuga, fazendo com que os resultados e respostas escapassem ao núcleo da investigação.

O primeiro cuidado adotado foi a coerência das partes que compõem o estudo: procurou-se abranger temas complementares num sistema único capaz de oferecer uma resposta consistente ao problema levantado, mobilizando para isso elementos conceituais e empíricos, históricos e contemporâneos, completando assim diferentes ângulos de ataque às questões orientadoras da pesquisa. O segundo foi a extensão das fontes utilizadas: houve uma preocupação em cobrir parte expressiva da produção recente veiculada nas principais revistas científicas internacionais dedicadas aos estudos rurais, em se reportar tanto à realidade dos países do capitalismo avançado quanto de países da América Latina, ou ainda em analisar o tratamento dado ao tema pelos principais organismos multilaterais e de cooperação internacional, o que pode ser mensurado pelas quinze páginas de bibliografia sobre o tema 
relacionada ao final do texto. O terceiro zelo, diz respeito à criteriosa escolha dos quadros teóricos de referência. Embora a consistência dos principais autores aqui evocados seja inconteste, é preciso dedicar também algumas linhas para explicar a opção por colocar em diálogo tradições até então dissociadas.

Seja pela amplitude do tema, seja pela tentativa em não restringir o instrumental teórico a autores somente da sociologia ou da economia, e sim em operar com o campo mais amplo da ciência ambiental, o fato é que as fontes de inspiração teórica foram múltiplas. Mas para garantir uma unidade de análise, que certamente se perde quando são muitos os esquemas explicativos mobilizados, dois grupos de autores acabaram por se impor como âncoras. No primeiro, estão autores que permitem compreender os fenômenos sociais relativos aos processos de desenvolvimento. No segundo, estão aqueles que permitem o diálogo entre instituições e estruturas sociais, enfatizadas nos anteriores, e o meio-ambiente. Todos eles têm em comum o fato de lidar com dinâmicas de longo prazo.

A referência inicial é a teoria institucionalista, de Douglass North, aplicada à análise da performance econômica de longo prazo. Destacadamente, para o tipo de problema aqui colocado, é extremamente útil a maneira como ele opera com a múltipla determinação do real, identificando instâncias empíricas fundamentais e combinando ferramentas teóricas derivadas de campos distintos nas idéias de instituições e mudança institucional como elementos explicativos da performance econômica. A importância deste pilar teórico é enorme, pois ele oferece uma análise consistente para a evolução de uma das dimensões centrais dos processos de desenvolvimento: a dinâmica econômica. E mais que isso, isto é feito de maneira a marcar um distanciamento em relação à explicação neoclássica.

Mas havia dois problemas em aplicar o modelo teórico de North ao objeto em questão. O primeiro está no fato de que suas análises são aplicadas à performance econômica, enquanto desenvolvimento é uma idéia mais ampla, fundada em outras dimensões. Além disso, sua ruptura com a economia neoclássica é apenas parcial, e uma das afirmações que dão corpo à hipótese aqui adotada extrapola justamente os limites desta abordagem, fundada no individualismo metodológico, e avança pelo domínio das estruturas sociais. Daí vêm os dois nomes que completam uma tríade de autores fundamentais neste texto. Para equacionar a necessidade de uma explicação que tenha em conta o papel das estruturas sociais na evolução 
de longo prazo a obra de Max Weber permite um diálogo bastante profícuo, pois assim como North, ele pôs no centro de suas análises o papel das idéias no estabelecimento das dinâmicas de longa duração. Mas em Weber idéias vão aparecer associadas com interesses, e interesses localizados em agentes posicionados em diferentes espaços do mundo social. Em seu pensamento, a dinâmica destas esferas é dada pelo crescente processo de racionalização em torno do qual se estrutura o sentido da ação social para os diversos agentes que o compõem. E para equacionar o problema relativo à conceituação da idéia de desenvolvimento e à relação entre suas diferentes dimensões, a obra de Amartya Sen é incontornável, por serem exatamente estas algumas de suas preocupações centrais. Sen oferece não só uma nova definição, que coloca em outro patamar os debates sobre desenvolvimento, agora impossível de ser tratado somente no âmbito do crescimento econômico, como, principalmente, consegue trazer para dentro da teoria econômica um diálogo aberto com as estruturas sociais, ou, em outros termos, sobre como hierarquia e desigualdade influenciam as possibilidades e os contornos de grupos sociais, regiões ou nações.

Mesmo com uma trinca de autores deste porte, no entanto, um aspecto fundamental do objeto e do problema colocados continuava sem iluminação teórica: o lugar da natureza nos processos de desenvolvimento. Sobre isto, a influência decisiva veio de dois autores que procuraram justamente incorporar esta dimensão às análises de evolução em longo prazo: Jared Diamond e Jane Jacobs. Do primeiro procurou-se reter a maneira de pensar o meioambiente como um dos constrangimentos que pesam sobre as escolhas humanas e sobre as instituições a que elas dão origem. De Jacobs, é particularmente eficaz a maneira como ela introduz a idéia de co-evolução - o que ajudará a pensar a relação entre a evolução dos espaços urbanos e rurais e entre a natureza e o mundo social -, e a abordagem do desenvolvimento como um processo onde novos conteúdos emergem de generalidades já existentes, o que permite operar com uma historicidade e uma espacialidade em sua determinação, aspectos importantes para aquilo que se pretende demonstrar ao longo das próximas páginas.

Evidentemente alguém poderia objetar que os referenciais trazidos com diferentes grupos de autores são conflitantes, o que em parte é verdade. Ou, noutra direção, que a dimensão ambiental só pode ser tratada à parte, por ser um domínio específico em relação à sociedade. Como resposta, uma excelente prova de que é possível incorporar a contento a dimensão 
ambiental ao lado de aspectos relativos às estruturas sociais está em Histoire des Agricultures du Monde - du néolithique au monde contemporain, de Mazoyer \& Roudart (1997/2002). Ali tecnologia, meio-ambiente e conflitos sociais são as instâncias explicativas fundamentais. A questão não está, pois, nos elementos mobilizados por cada teoria, e sim na coerência do arranjo que se faz a partir deles, cuja única medida é a capacidade em instrumentalizar a compreensão das múltiplas determinações da realidade; no presente caso, as múltiplas determinações do desenvolvimento nos espaços rurais. 


\section{PARTE I}

\section{DESENVOLVIMENTO}




\section{Capítulo 1 - Desenvolvimento}

Uma interrogação fundamental a ser enfrentada por qualquer trabalho que se pretenda elucidativo e que envolva a idéia de desenvolvimento é saber se é possível decantar o que há de científico e o que há de normativo, de ideológico, de meramente discursivo por detrás dela. Responder a esta pergunta é o intuito maior deste capítulo ${ }^{23}$. Mas embora a questão pareça simples, é preciso reconhecer de partida que poucas idéias têm sido objeto de tamanhas controvérsias como a idéia de desenvolvimento. De um lado, há os que reclamam a ela status científico, legitimidade política, conteúdo técnico. De outro, os que a vêem como instrumento de manipulação ideológica, crença esvaziada de virtude. Atualmente, várias visões distintas coexistem e disputam os significados da idéia de desenvolvimento. A primeira é a mais usual, e pode ser encontrada em qualquer bom manual de economia: nela desenvolvimento é tomado como sinônimo de crescimento ou, numa pequena variação, o desenvolvimento é resultado do crescimento (Rostow, 1960; Jones, 2000). A segunda, mais sofisticada, toma o desenvolvimento como mito. Mas não necessariamente em sua acepção enganosa, e sim em algo mais próximo do que se poderia chamar por poder mobilizador e organizador do mito (Furtado, 1974). Uma terceira vertente, por sua vez, não vê qualquer validade teórica ou prática na idéia de desenvolvimento, apenas ilusão ou argumento ideológico falseador das reais intenções das políticas cunhadas a este título (Rist, 2001; Rivero, 2003). Isto sem falar nas inúmeras adjetivações que surgiram à luz da crítica aos rumos do desenvolvimento no capitalismo contemporâneo e que deram origem a teorias inovadoras, como a do "desenvolvimento como liberdade" (Sen, 2000), ou a utopias de grande valor ético e social, como a retórica do "desenvolvimento sustentável" (Comissão Brundtland, 1985).

Por tudo isso, e pelas características específicas da idéia que se pretende tomar por objeto, é preciso ir além da mera confrontação entre diferentes definições do desenvolvimento. É preciso enfrentar aquilo que Pierre Bourdieu (2001-a) chamava de amnésie de la génése, isto é, o descolamento entre o contexto de origem de uma idéia e a evolução posterior que lhe é

\footnotetext{
${ }^{23}$ Partes deste capítulo foram originalmente apresentadas na forma de artigo, no Encontro Anual da Associação Nacional de Pós-Graduação e Pesquisa em Ambiente e Sociedade (Anppas), em 2004, e no Encontro Anual da Associação Nacional de Pós-Graduação em Ciências Sociais (Anpocs), de 2005. Cf. Favareto (2004-b, 2005-b).
} 
correspondente. Tal procedimento permite colocar em suspenso as categorias de apreensão do objeto evitando assim seu uso ingênuo. O risco implícito nisto, contudo, é incorrer numa espécie de cardápio de teorias, em um maçante patchwork de conceitos justapostos. Como o objetivo maior deste trabalho é a compreensão das categorias explicativas dos fenômenos relativos ao desenvolvimento de regiões rurais, e não a idéia de desenvolvimento per se, o percurso que envolve esta gênese e desdobramentos posteriores será aqui apenas aproximado, e não exaustivo. Mostrar por que mecanismos isso acontece, quem são os agentes de tal processo e como suas práticas constroem tal resultado deveria ser o expediente desejável de uma sociologia fina de uma idéia científica. Mas, dada a longa duração da história da idéia de desenvolvimento, seria extremamente difícil reter as instâncias empíricas fundamentais necessárias a uma sociologia fina de seu surgimento e evolução ${ }^{24}$. $\mathrm{O}$ intuito aqui é apenas, como destacado pouco acima, evitar o uso ingênuo da idéia e, junto disso, delinear um quadro teórico adequado a uma análise do desenvolvimento dos espaços rurais.

A fim de destacar as continuidades e rupturas, os portadores e as bases teóricas e sociais dos discursos sobre desenvolvimento, as próximas duas seções procuram abordar o mesmo tema, sob ênfases distintas. No primeiro deles, retoma-se a evolução da idéia de desenvolvimento, de sua trajetória histórica. No segundo, é feita uma discussão mais aprofundada sobre suas bases teóricas. $\mathrm{O}$ argumento central que se pretende demonstrar neste capítulo pode ser resumido na afirmação de que, à idéia de desenvolvimento e à explicação dos processos sociais que a ela correspondem, vêm sendo elaborados importantes aparatos científicos que permitem não só identificar suas dimensões fundamentais como compreender a relação entre elas. Nestes termos, mesmo sendo também uma idéia-força, quase um valor social, a idéia de desenvolvimento e os processos econômicos e sociais correspondentes podem ser teoricamente elaborados e cientificamente analisados. Claro que isto demanda reconstruir um campo de abordagem que refaça elos partidos, sobretudo no decorrer do último século, num movimento inerente ao natural processo de crescente especialização e autonomização dos ramos científicos. Em diversas disciplinas do campo das ciências sociais, com destaque para a sociologia, a economia e a geografia, tem havido um importante movimento de reaproximação, de cujo aprofundamento podem surgir as bases para programas e projetos de pesquisa que sejam, ao mesmo tempo, menos ingênuos do que aqueles que tradicionalmente

\footnotetext{
${ }^{24}$ Aqui e ao longo de todo o texto, quando se fala em desenvolvimento a referência é seu sentido mais amplo que aquele contido na principal vertente recente - o desenvolvimento econômico - , esta beirando apenas meio século de existência (Arndt, 1998).
} 
se erigiriam no período em que a explicação do desenvolvimento esteve reduzida à sua dimensão econômica - ou mais precisamente, à sua diluição no crescimento econômico -, e também mais promissores do que os que reduzem esta idéia e os anseios nela contidos a mera operação de manipulação ideológica.

\section{1 - a longa trajetória das idéias sobre desenvolvimento}

O desenvolvimento da humanidade é, claro, bem anterior às tentativas de sua definição. A evolução biológica do homem é resultado de um processo de longuíssima duração. E o primeiro grande salto realizado no intuito de tentar submeter sob seu domínio os desígnios de sua condição sobre a Terra é algo que data de dez a doze mil anos atrás: é nesta época que surge a agricultura, numa revolução de importância similar ou superior à Revolução Industrial, à medida que permitiu a organização dos crescentemente numerosos assentamentos humanos, a realização de inúmeros progressos técnicos, desde a complexificação da ferramentaria e de técnicas de produção até, posteriormente, o surgimento da escrita e das chamadas grandes civilizações ${ }^{\mathbf{2 5}}$. Faz bem menos tempo, "apenas" uns dois mil e quinhentos anos, que a humanidade tenta, a par das explicações mágicas, formular concepções sistemáticas para o sentido de sua existência e para a evolução do real. Elas aparecem sempre através de definições expressas em um conjunto de palavras correlatas como natureza, evolução, desenvolvimento, todas elas com uma mesma raiz etimológica. Ao largo dessa sua longa trajetória de vinte e cinco séculos, a idéia de desenvolvimento passou por quatro grandes etapas, obviamente com continuidades e rupturas em cada uma delas. Como se verá a seguir, o que marca a virada de um a outro período é, além de uma mudança substantiva nos alicerces empírico-cognitivos e na sistematização da idéia, uma mudança igualmente substantiva no tipo de portador dos discursos e explicações que a envolvem.

\subsection{1 - da gênese ao evolucionismo}

Desenvolvimento, progresso, evolução. A estas palavras poderia se juntar algumas outras como modernização, ocidentalização. Todas têm em comum o fato de serem usadas para tentar expressar o movimento histórico da humanidade e seu sentido. O livro de Gilbert Rist

\footnotetext{
${ }^{25}$ Ver a respeito Mazoyer \& Roudart (1997/2002). .
} 
(2001), Le développement: histoire d'une croyance occidentale , embora apresente uma hipótese fraca - o desenvolvimento seria apenas uma espécie de "invenção" do mundo ocidental - traz uma contribuição interessante ao tentar discutir por que, dentre aqueles termos, foi justamente a idéia de desenvolvimento que teve o maior apelo. É exatamente no nascimento das interpretações racionais do mundo, entre os gregos, que uma certa idéia de evolução e desenvolvimento foi sendo formada. Em Aristóteles, esta gênese está ligada à própria especulação sobre a natureza do mundo. Em grego, natureza - physis - deriva etimologicamente do verbo phuo, que significa crescer, se desenvolver. Natureza é, portanto, segundo o filósofo grego, "a geração de coisas que se desenvolvem", é "a essência das coisas que têm, elas mesmas, um princípio de movimento". A ciência, em tais condições, poderia ser definida como a teoria da "natureza" das coisas e, pois, de seu desenvolvimento. E entender as coisas de maneira racional significaria considerá-las segundo sua natureza, vale dizer, relativamente a seu desenvolvimento. Lucrécio retomou a idéia de geração e evolução, em sua De natura rerum. Ali, a natureza é concebida como aquilo que está no princípio do crescimento, à medida que a palavra em latim natura, deriva etimologicamente do verbo nascor - nascer. E no latim, tanto desenvolvimento como evolução derivam etimologicamente do verbo volvere, cuja tradução para o inglês se aproxima do verbo to roll, como mostra Hodgson (1993). O mesmo autor observa que os verbos auxiliares evolvere e revolvere são mais explícitos, denotando respectivamente um movimento progressivo e um movimento regressivo. Assim, o termo evolução e seu par - desenvolvimento - surgem, também no latim, presos à idéia de algo direcional, de algo relativo a uma atividade em certa medida com um sentido pré-destinado. Se o mundo, como disse Lucrécio, ainda estava em sua juventude, nada o impediria de encontrar sua maturidade e, um dia, seu declínio. Porém, como a metáfora diz respeito à natureza das coisas, há ali uma idéia cíclica, fiel à natureza cíclica da natureza: tudo o que nasce, cresce, atinge maturidade, declina e morre, se fundindo à matéria original, num perpétuo recomeço (Rist, 2001).

Começava ali, com os filósofos da Antigüidade, uma tradição que, no que diz respeito à idéia de desenvolvimento e evolução, perdurou até os fins do século XX. A tarefa de sistematização das grandes concepções do mundo e seu sentido sempre foi uma tarefa dos grupos intelectuais nas diferentes sociedades através dos tempos, seja pelos intelectuais leigos, seja pelos intelectuais religiosos, mas sempre pelas camadas altamente intelectualizadas. O que vai mudar de uma etapa a outra da história é justamente a posição 
social destes intelectuais. Como lembra Weber (1988), à medida que a racionalização do mundo avança, ganha peso o papel das grandes sistematizações do mundo e, com isso, crescem em peso e diversificação os constrangimentos sociais que recaem sobre seus portadores. Claro que já entre os gregos, por exemplo, estava bem presente tal tipo de condicionante - o fim de Sócrates, um de seus mais brilhantes expoentes bem o demonstra. Mas com o passar do tempo, o tipo de constrangimento muda, e isto importa decisivamente na definição do conteúdo das idéias. A ascensão do cristianismo como principal instituição do mundo ocidental criou, exatamente por isso, uma nova situação. Na passagem da Idade Antiga à Idade Média, na virada do século IV para o século V, Santo Agostinho tentou conciliar uma filosofia da história com a herança da tradição intelectual anterior à teologia cristã, o que significava reequacionar três problemas derivados da teoria aristotélica e mantidos nos filósofos que o seguiram. Primeiro, o problema da intervenção divina, pois, enquanto em Aristóteles importava a força silenciosa que está no princípio da natureza e de seu desenvolvimento, no cristianismo é através dos acidentes da história que a força de Deus se mostra presente. Segundo, o problema da espontaneidade dos fenômenos naturais, pois para o cristianismo há algo supranatural que se junta à natureza e lhe justifica e dá sentido. Terceiro, o problema da mudança e do retorno, já que para o cristianismo é preciso que haja um começo, um meio e um fim, onde o celestial representa o ápice e o objetivo. A solução agostiniana consistiu em preservar os elementos constitutivos dos ciclos, aplicando-lhes à totalidade da história universal como manifestação dos desígnios de Deus. Saem os ciclos sucessivos de ascensão, apogeu e declínio, de Aristóteles, e entra em cena a idéia de um único ciclo. Tomava forma aqui a concepção, ainda tão cara aos dias atuais, da história como um movimento linear. Mas esta não seria a única implicação da filosofia de Santo Agostinho para a história e a idéia de desenvolvimento. Outros três aspectos derivam destas adequações: a história passa a ser vista como algo que envolve o conjunto do gênero humano; os eventos históricos não têm importância senão no que diz respeito ao todo mais amplo em que se situam, neste caso, o plano de Deus. Apesar das aparências sinuosas a história obedece a uma necessidade, novamente relativa ao plano divino (Rist, 2001).

Dependendo do autor, situa-se no século XI ou no século XV o período que enseja o desgaste mais acentuado das concepções de mundo compatíveis com a época medieval. Mas é somente a partir dos meados do século XVII que vão se materializar as maiores rupturas com esta ordem de pensamento, marcadamente com a ascensão do racionalismo. E é, finalmente, no 
século seguinte que ocorrem os grandes eventos que vão solapar de vez os quadros de referência do mundo medieval e impulsionar de maneira irreversível o deslizamento das explicações sobre a evolução do real: o desejo e a possibilidade da mudança social, que tem por marco definitivo a Revolução Francesa; a crescente importância dos mecanismos de mercado repousando sobre o jogo de uma relativa livre concorrência, alavancada pela queda progressiva das monarquias européias até a formação dos grandes impérios modernos; o progresso científico, com todo o rol de descobertas, inovações técnicas e especialização de saberes característicos do período inaugurado com o Iluminismo. Nesta transição de mais ou menos cinco séculos, tornou-se possível aos homens se permitir interrogar em domínios crescentes da vida social a ordem imanente à mudança (Elias, 1970/1991). Os homens começaram a compreender mais e mais mudanças na natureza e na sociedade que não podiam ser explicadas por causas imutáveis. A principal ruptura introduzida à esta época está em que a explicação da evolução do real passa a ser acessível por meio da análise e observação de fenômenos empíricos e não por derivação de sentidos extramundanos, tal qual na filosofia agostiniana.

Mas também houve continuidades nas grandes tentativas de sistematização da evolução e mudança do mundo social que se cristalizam, sobretudo, no século XIX. A principal talvez seja o caráter teleológico pronunciado de algumas teorias: de maneira compatível à filosofia agostiniana, a sociedade enfrentaria um processo de evolução social mais ou menos "automático", em direção a uma ordem social superior. Ao contrário do que acabou por se firmar no senso comum, nestas vertentes superior deve ser entendido como mais alto grau de algum caractere empírico fundamental, o qual varia segundo o sentido da evolução formulado em cada autor ou teoria - a formação superior é a mais complexa em Spencer, é a que apresenta mais alto grau de progresso nas suas forças produtivas em Marx, assim como será superior, posteriormente, em Weber, a formação mais racionalizada ${ }^{26}$. Simultaneamente, no campo da biologia a idéia de evolução também se firmava à mesma época. Aplicada sistematicamente por Albrecht von Haller no meio do século XVIII ela só seria popularizada no século XIX (Hodgson, 1993).

\footnotetext{
${ }^{26}$ Com a ressalva de que, em Weber, superior não significa necessariamente melhor. Não há dúvida de que ele considera as sociedades mais racionalizadas formas superiores se comparadas às suas predecessoras, à medida que se desprendem de concepções mágicas do mundo. No entanto, a famosa metáfora do futuro como "gaiola de ferro" dá a exata medida da contradição e do desconforto que tal tipo de evolução engendra para a condição humana.
} 
É bom destacar, no entanto, que entre o evolucionismo social e o evolucionismo em biologia há muito mais distância do que proximidade. Inicialmente a noção de evolução fora difundida principalmente por Spencer, e não por Darwin. Em Spencer, como indicado acima, evolução podia ser entendida como um movimento cujo sentido estava ligado ao movimento que vai do mais simples ao mais complexo, como mostra sua classificação das sociedades. $\mathrm{Na}$ obra do biólogo inglês, diferentemente, evolução diz respeito ao processo de diversificação, expressa em sua obra na análise da origem e da seleção natural das espécies ${ }^{27}$. Talvez por isso o próprio Darwin, que acabaria sendo seu principal divulgador, tenha relutado tanto em adotar a idéia de evolução em seus escritos - ela só aparece na sexta edição da Origem das espécies (Hodgson, 1993).

Como foi assinalado anteriormente, no latim tanto desenvolvimento como evolução derivam etimologicamente do verbo volvere, e os verbos evolvere e revolvere apontam respectivamente um movimento progressivo e um movimento regressivo. Com isso, o termo evolução e seu par - desenvolvimento - se firmaram presos à idéia de algo direcional, de algo relativo a uma atividade em boa medida pré-destinada. Quando o racionalismo e o empirismo se tornam as formas de pensamento sistemático predominantes, ocorre um deslizamento semântico com correspondências nos sistemas mentais de interpretação do real, no qual as idéias de evolução e desenvolvimento vão ser assimiladas à idéia de progresso, como bem destaca o clássico estudo de Nisbet (1985): correspondia ao ideário inaugurado no Iluminismo, e aprofundado com a Revolução Industrial, que a evolução se converteria naturalmente em progresso, alcançado pelo conhecimento e domínio das forças da natureza. A ascensão da idéia de progresso marca uma transição: não se teve uma teoria do progresso, mas a passagem da idéia de evolução para a de progresso foi uma espécie de ante-sala do rapto da idéia de desenvolvimento pela economia, com a redução da evolução ao progresso e deste ao crescimento. Não é gratuito, também, que a idéia de progresso apareça na história no momento de constituição do campo científico, enquanto a idéia de crescimento, como se verá, corresponde ao seu auge, não por acaso com uma ascensão crescente da economia no rol das modernas disciplinas científicas.

\footnotetext{
${ }^{27}$ Uma expressão clara da confusão que se faz entre estas duas maneiras de conceber a evolução é facilmente encontrável em muitos livros didáticos ou mesmo científicos. Em geral, junto de textos sobre evolução é comum haver a clássica ilustração que mostra uma série de desenhos, dos primatas ao homo sapiens, como se houvesse uma linearidade nesta linhagem. Diferente disso, a ilustração feita por Darwin para exemplificar sua teoria é bem parecida com o desenho de uma raiz de árvore, onde, a partir de um ancestral comum, estabelecem-se diferentes linhagens e direções da evolução.
} 
É claro que houve ao longo de todo este período exceções e nuanças nada desprezíveis. A começar por Maquiavel e seu realismo político em pleno Renascimento. Posteriormente, $O$ Discurso sobre a igualdade entre os homens, de Rousseau, foi escrito a partir de um edital da Academia de Dijon, que indagava se o progresso das artes e da ciência beneficiava a humanidade: sua resposta, além de brilhante e engenhosa a ponto de se constituir num dos mais belos e lidos textos filosóficos, foi, no mínimo, bem crítica. E mesmo no empirismo britânico a apologia do progresso é atenuada pela constatação de Adam Smith de que o mercado não funciona de maneira tão equânime quanto se poderia imaginar (nas negociações entre patrões e empregados, por exemplo). Esta visão crítica do progresso está presente nos primeiros esboços das teorias socialistas e é uma das bases do pensamento do próprio Marx, embora ali, como assinalado pouco acima, ela se funde dialeticamente a seu objeto apresentando como síntese a superação pela suposta ordem socialista. O coro dos dissonantes não poderia estar completo sem uma menção àquele que levou este tipo de crítica e desconfiança às raias do extremo em termos filosóficos e que, não por acaso, influenciaria nomes do porte de Weber e Freud: Friedrich Nietzsche.

A virada para o século XX marcou o fim desta longa trajetória em que a idéia de desenvolvimento esteve predominantemente associada à idéia de evolução. Para Norbert Elias (1970/1991), a reação contra as teorias sociais da evolução talhadas no século XIX foi extraordinariamente violenta durante o século XX porque os conhecimentos relativos à evolução das sociedades sobre os quais aqueles pensadores puderam se apoiar eram excessivamente limitados se comparados àqueles disponíveis no período de consolidação dos campos disciplinares específicos das ciências sociais. E seria justamente por isso que aos primeiros fora possível divisar grandes linhas de evolução das sociedades. A massa de detalhes que era preciso manipular para a elaboração de modelos globais ainda não excedia sua capacidade de apreensão: como diz Elias (1970/1991: 184), “eles viam melhor a floresta porque não distinguiam as árvores; quanto a nós, as árvores nos escondem a floresta". É exatamente este paradoxo que explica a nova ruptura que teve lugar no século XX. De um lado, a mistura de ideal social e realidade contida nos modelos de evolução social elaborados no século XIX teria sido responsável por boa parte do desinteresse dos sociólogos do século XX a estas teorias. De outro, ainda segundo Elias, parece ser justamente a rendição inconsciente de muitos cientistas sociais contemporâneos aos seus ideais sociais o que 
confere às sociedades atuais uma superioridade em relação a suas antecessoras, levando assim a um abandono dos problemas relativos às dinâmicas de longo prazo em benefício de problemas específicos e tidos como de maior urgência e atualidade.

\subsection{2 - da evolução ao crescimento}

Apesar das rupturas destacadas, não seria correto dizer que ao longo de todo o século $\mathrm{XX}$ a idéia de evolução esteve completamente dissociada da idéia de desenvolvimento. A virada do século XIX para o século XX é palco de uma crescente institucionalização do campo científico e de muitas de suas disciplinas $\mathrm{Na}$ sociologia, institucionalizava-se o pensamento marxista, desde seu início premido entre a cientificização e a política: surge nesse período $O$ desenvolvimento do capitalismo na Rússia, de Lênin. Ao mesmo tempo, estabeleciam-se perspectivas concorrentes de explicação, marcadamente a sociologia funcionalista de Durkheim e a sociologia compreensiva de Weber. Numa certa vertente marxista, a idéia de desenvolvimento associada à evolução permaneceu presente, sobretudo naqueles que efetivamente lançaram mão da concepção de história em Marx ao se empenhar em analisar o movimento do real como resultante da evolução de conflitos estruturados em torno da luta de classes e seus correspondentes. Na vertente weberiana o componente evolucionário é ainda mais forte, mas é esta mesma corrente a que menos influência exerceu sobre a expansão da sociologia até o último quarto do século quando há uma clara inflexão. $\mathrm{Na}$ economia o embate se estruturou opondo aqueles que deram corpo ao que ficou conhecido como paradigma neoclássico em economia, expresso nos nomes de Jevons, Menger e Walras, e aqueles que destacaram o peso das instituições na determinação da dinâmica econômica, como Veblen. Este último, aliás, foi justamente aquele que nas ciências sociais chegou mais perto da analogia com a evolução por seleção natural tal como explicada na biologia. Em Veblen, o que é imanente à estrutura e à mudança nas economias são as instituições, e explicá-las significa entender porque umas se adaptam através do tempo e outras sucumbem. Como se sabe, o pensamento neoclássico obteve uma fragorosa vitória ante os primeiros institucionalistas, algo que só começou a ser abalado também no último quarto do século, com a Nova Economia Institucional. De resto, cumpre assinalar ainda que em outros autores uma certa idéia de evolução continuou presente - para citar apenas alguns, em Schumpetter e Hayek, como mostra a taxonomia de Hodgson (1993) -, mas aí este componente de evolução 
já aparece subordinado a outros elementos dos quadros conceituais de cada um destes autores.

Tanto na sociologia como na economia, prevaleceram durante boa parte do século $\mathrm{XX}$ as teorias que se sustentavam em alguma forma de equilíbrio, ou que permitiam algum grau de previsibilidade. Na sociologia, como se sabe, houve uma polarização entre marxistas e funcionalistas: nos primeiros, apesar de haver uma determinação da história pelo conflito e a luta de classes, há um momento de equilíbrio em que os antagonismos se diluem; e no segundo grupo, a idéia de equilíbrio é simplesmente central, como bem o demonstram certas categorias centrais deste pensamento como função e anomalia. No caso da economia, por sua vez, a supremacia dos neoclássicos sobre os velhos institucionalistas significou a vitória de uma concepção em que a história perde poder explicativo e cede terreno para uma modelização teórica fundada numa abstração das interações sociais dos processos de troca, cujas bases são o individualismo e a presunção do comportamento maximizador do homem e seus desdobramentos para a constituição da chamada racionalidade econômica. Tanto em sociologia como em economia, portanto, no decorrer do último século a história, mesmo quando se manteve presente, cedeu lugar a modelos que de uma ou outra forma se apoiaram em metáforas de mecânica social, negando as metáforas biológicas. E, não obstante, quase sem exceção, os grandes autores das ciências sociais do século XX - mesmo os classificados como evolucionistas, como Schumpetter, cuja obra $O$ desenvolvimento econômico também data do início do século -, sempre que puderam fizeram questão de demarcar os perigos da metáfora biológica (Hodgson, 1993) ${ }^{\mathbf{2 8}}$.

Este movimento nos quadros teóricos e as correspondências que se pode notar em disciplinas como a sociologia e a economia não podem ser atribuídas somente a desenvolvimentos conceituais. Se o distanciamento da biologia precisa ser entendido como parte das estratégias de afirmação de competências específicas de cada sub-campo disciplinar, é preciso agregar a

\footnotetext{
${ }^{28}$ Isto talvez se explique pelo fato de que tais autores reconheciam que há um primado ontológico nas ciências humanas que as diferencia das ciências da natureza. Algo que pode ser claramente percebido na maneira como ocorre a mudança evolutiva: enquanto no mundo natural ela só acontece muito lentamente, através da seleção das espécies, no mundo social elas podem ocorrer no intervalo de uma única geração, pela faculdade do aprendizado e da razão. Na biologia, ao contrário, a idéia de evolução reinou com primazia durante todo o século XX, com o recém falecido Ernst Mayr como grande expoente e com as principais disputas se dando entre os evolucionistas, e não entre esta corrente e outras. Uma exceção no uso da metáfora biológica em ciências sociais é Émile Durkheim, mas também em seu pensamento há todo um cuidado em delimitar a fronteira que distingue este domínio dos fatos sociais. No sociólogo francês, como foi dito, a história não tem peso explicativo, diferente da lógica funcionalista, expressa principalmente em termos de mecânica e organicidade.
} 
isso a compreensão de que o tipo de constrangimento externo que passou a pesar sobre estes sub-campos disciplinares também muda no período em questão. O campo científico e o campo econômico, junto com o campo político, adquirem prevalência crescente sobre as demais esferas: o enorme progresso econômico desencadeado com os processos associados à Revolução Industrial e a expansão que ela gerou criaram as condições para que se legitimasse a retórica que faz repousar nesta dimensão do real, a economia, o mais alto grau de determinação sobre as demais. Se o que determina é o econômico, e o que explica o econômico é o científico, então a explicação científica dos fenômenos econômicos só poderia adquirir prevalência. Cria-se com isso uma homologia estrutural, no sentido dado por Bourdieu, entre a disciplina economia e o lugar da economia na sociedade. Desde então as interdependências entre estes dois campos - a economia e as ciências econômicas -, e entre estes dois campos e a política vão se tornar mais e mais estreitas ${ }^{29}$. Assim é que Lord Keynes além de ser associado à intelectualidade e à classe artística inglesa de sua época circulava também entre a nobreza e fora por ela chamado a colaborar na construção do sistema financeiro mundial pós-guerra. Da mesma forma, foi sob o patrocínio da coroa inglesa que se formou o think thank que reuniu nomes que viriam a se tornar influentes pensadores em ciências econômicas e que deu origem à economia do desenvolvimento em suas diferentes vertentes. Boa parte destes mesmos pensadores viria a colaborar com as políticas e orientações de órgãos internacionais. Sem falar no crescente fluxo de quadros intelectuais das escolas de economia à burocracia estatal e em seu posterior retorno, sempre realimentando as interdependências entre os três campos. Olhando sob este ângulo fica mais fácil entender por que tipo de constrangimento social as idéias baseadas nas dinâmicas de longo prazo cedem espaço para outras, onde impera um mais alto grau de aplicabilidade interventiva de seus resultados analíticos, de seu poder normativo, enfim.

Nos países da periferia do capitalismo o mesmo movimento social e científico ocorreu. Seja pela influência dos organismos internacionais - basta lembrar o papel de absoluto relevo da Comissão Econômica para a América Latina (Cepal) -, seja pela grande circulação das elites desta periferia, favorecendo sempre uma absorção e um certo alinhamento rápido às teorias em voga, o fato é que também no chamado "Terceiro Mundo" as interdependências entre os campos político, econômico e científico foram bastante estreitas. É evidente que uma vertente

\footnotetext{
${ }^{29}$ Uma relação muito bem retratada e analisada por Frédéric Lebaron (2000) para o caso francês, e por Loureiro (1995) e Paulani (2005), para o caso brasileiro.
} 
que tem expoentes como Oswaldo Sunkel, Raul Prebisch, Fernando Henrique Cardoso, Ruy Mauro Marini, para ficar restrito a alguns nomes, representa um capítulo à parte. Ainda mais quando se relembra que alguns destes autores falavam de maneira nítida sobre o papel das instituições e da história. Mas mesmo entre este grupo, o fato é que as perspectivas do desenvolvimento sempre se fizeram presentes como sinônimo de crescimento econômico ${ }^{30}$ : tanto entre os chamados "dependentistas", em suas diferentes linhagens, como na obra de autores como Celso Furtado. No primeiro caso, em que pese a existência de explicações dissonantes, um ponto central está na idéia de que a posição da periferia não seria uma mera questão de estágio a ser superado, mas de um tipo específico de inserção: em vez da história como determinante, uma certa mecânica das trocas conflituosas. No segundo caso não se pode dizer que a história está ausente; ao contrário, trata-se justamente de uma análise de história econômica onde o crescimento pode assumir diferentes estilos a depender do tipo de equacionamento das variáveis político-sociais, mas ainda aí, e este é o destaque que se pretende realçar neste momento, o vetor é o crescimento econômico ${ }^{31}$.

Esta prevalência do crescimento como sinônimo de desenvolvimento, contudo, durou relativamente pouco quando tomada na perspectiva aqui adotada, de uma pequena história da longa duração do conceito. Ao dizê-lo, não se está nem de longe afirmando que a assimilação entre crescimento e desenvolvimento tenha acabado: uma simples olhada pelos jornais nos dias atuais revela que esta associação é a corrente no senso comum. E mesmo nos meios científicos não é preciso muito esforço para encontrar confirmações. Dois dos mais importantes manuais de economia dispensam ao tema tratamento similar. Mankiw (2001) simplesmente retirou de seu manual a expressão desenvolvimento, por considerar que, como se trata exatamente da mesma coisa que crescimento, é melhor adotar este "termo" para ir direto ao núcleo da idéia: em resumo, desenvolvimento é crescimento. Em Jones (2000), crescimento é considerado não só o principal meio, mas a principal indicação de desenvolvimento, pois é onde há dinamismo econômico prolongado que se encontram também os melhores indicadores sociais e de qualidade de vida: em resumo, desenvolvimento é tratado como crescimento.

\footnotetext{
${ }^{30} \mathrm{O}$ fato de se destacar aqui o viés econômico não significa, contudo, o monopólio exclusivo da economia sobre a questão. Cardoso (1995) elenca uma série de expoentes do debate para concluir que se tratava, predominantemente de sociólogos.

${ }^{31}$ No mesmo texto citado na nota anterior, Cardoso considera que nos anos 70 a concepção de Furtado se desloca de uma abordagem em que o desenvolvimento é um processo objetivo, explicável por leis econômicas e históricas, para uma concepção em que desenvolvimento é um mito, um valor, uma idéia-força, residindo nisso mesmo sua força: reunir e orientar as energias humanas e seus recursos em uma determinada direção. Ver também Cardoso (1980).
} 
Porém, mesmo nestes meios mais afeitos às lides com a idéia de desenvolvimento, como a academia, esta assimilação já deixou de ser natural e intocável. Se durante a "Era de Ouro" do capitalismo mundial não era possível fazer uma distinção entre desenvolvimento e crescimento, aos poucos foi ficando cada vez mais claro que o crescimento econômico pode não só não contribuir para que o conjunto da sociedade alcance uma situação de bem-estar, como pode igualmente contribuir para que aumente a desigualdade entre ricos e pobres, gerando sérios problemas de coesão social. Este tipo de fissura no poder de persuasão da idéia de crescimento como sinônimo de desenvolvimento pode ser sentido também em várias situações: nos resultados pouco alentadores dos investimentos realizados em países periféricos, em sensações de desconforto de diferentes tipos vividas por parcelas significativas de pessoas dos países desenvolvidos, na consciência de que diferentes estilos de vida podem comportar diferentes padrões de satisfação de necessidades materiais, ou ainda na descoberta científica mesmo de que em determinadas situações o crescimento econômico pode não ser o impulsionador, mas sim o resultado de determinado tipo de intervenção social. Esta erosão da coesão entre crescimento e desenvolvimento é uma das expressões da perda do poder de persuasão de outra das idéias correlatas e que lhe serviu de corolário: a idéia de progresso $^{32}$.

O fim da idéia de progresso (Nisbet, 1985) é o crepúsculo desta associação entre melhoria da condição humana mediante um movimento natural de expansão de suas possibilidades materiais e, por decorrência, físicas e culturais. Já a idéia de desenvolvimento parece estar tendo outro destino: ela passa a sofrer uma tentativa de disputa social pelas suas significações possíveis, em vez de simplesmente morrer ou perder por completo seu apelo científico, político ou utópico.

Uma das expressões organizadas dessa insatisfação crescente com os rumos do debate sobre desenvolvimento pode ser encontrada no movimento ambientalista internacional que toma corpo nesse período, na virada dos anos 60 para os anos 70, e vem se tornando cada vez mais robusto desde então. Outra pode ser encontrada em teorias científicas destoantes do chamado

\footnotetext{
${ }^{32}$ Em Veiga (2005) há uma comparação sobre o desempenho dos países do capitalismo avançado no Índice de Desenvolvimento Humano e no Índice de Sustentabilidade Ambiental produzido pelas Universidades Columbia e Yale. Ali fica muito claro como, em muitos casos, riqueza e bons indicadores sociais andam bem distantes de preocupações com a natureza e esforços em conservação ambiental.
} 
mainstream. Em ambas a nova retórica de que as duas vertentes são portadoras se constitui a partir da crítica social, a partir de uma certa crise do poder explicativo da idéia tradicional de desenvolvimento. Uma crise que vai desembocar em diferentes desaguadouros: numa explosão de adjetivações (desenvolvimento includente, desenvolvimento social, desenvolvimento local, para ficar apenas em alguns poucos exemplos), numa conseqüente banalização dos significados da idéia e, como não poderia deixar de ser, numa tentativa de reconceituação científica dos processos de desenvolvimento.

\subsection{3 - crise, polissemia, banalização... ciência}

Embora o marco inegável de contestação dos rumos do progresso do Ocidente se localize nos meados dos anos 60, tendo talvez como ápice o Maio de 68 francês, desde bem antes se pode encontrar obras importantes de questionamento. Nos EUA, por exemplo, nos anos 30 a obra de Upton Sinclair - The Jungle - já fazia uma profunda crítica das condições de trabalho e saúde dos alimentos. Seus impactos guardam relação com a criação da FDA (Food and Drug Administration), anos mais tarde. Da mesma forma o livro de Rachel Carson - Primavera silenciosa -, de 1964, teve um enorme impacto e contribuiu decisivamente para a criação da EPA (Environmental Protection Agency). Nestas e em tantas outras obras, estava em questão não só o sentido assumido pelo progresso ocidental, mas a ideologia mesmo do progresso e, pois, do desenvolvimento. Nesta passagem dos anos 60 para os anos 70 foram inúmeros os movimentos de crítica social que se materializaram em eventos, organização de grupos militantes, em todo um caldo de cultura, enfim, onde o mito do progresso estava em causa.

Junto com esta crescente contestação social, e fortemente tributária dos elementos de crítica de obras como as acima citadas, um esboço de resposta sistemática aparece na Conferência de Estocolmo sobre meio-ambiente, em 1972. A noção de ecodesenvolvimento (Sachs, 1985) que dali emergiu sinalizava diretamente a necessidade de se instituir um outro padrão de relação entre a sociedade e a natureza, onde a degradação crescente desse lugar a práticas fundadas num melhor aproveitamento dos recursos naturais. Uma década e meia mais tarde a noção de ecodesenvolvimento viria a ser praticamente substituída pela idéia mais genérica, e em parte por isso mesmo mais aceita, do desenvolvimento sustentável, que ficou consagrada pela Comissão Brundtland (1987), segundo a qual o desenvolvimento que se pretendia era aquele capaz de preservar os recursos necessários às gerações vindouras. 
A gradativa substituição da definição "ecodesenvolvimento" por "desenvolvimento sustentável" nos documentos oficiais de organismos multilaterais e em parte do movimento ambientalista pode ser vista não somente como a troca de uma expressão por outra, mas como uma adequação de sentido ao paradigma dominante de organização das idéias sobre desenvolvimento. Isto é, tanta importância quanto a Conferência de Estocolmo para as idéias sobre desenvolvimento e meio-ambiente teve o relatório do Clube de Roma, da mesma época, que apontava a escassez eminente de uma série de bens naturais. Ao optar pela definição “desenvolvimento sustentável”, tal como expressa no Relatório Brundtland, escolhia-se uma conceituação que, em primeiro lugar, não sinalizava a necessidade de se instituir um outro padrão, um outro estilo; em segundo lugar, esta opção era totalmente compatível com a tentativa de resposta ao alerta levantado pela crítica ambiental apoiada no paradigma da escassez. Na Conferência do Rio de Janeiro, em 1992, este movimento teve seu ápice, mas desde então tem patinado nas tentativas de implementação de acordos e na sua materialização na tentativa de levar adiante uma agenda de proposições para o século XXI capaz de cobrir a atuação de orgãos internacionais e de governos nacionais ${ }^{33}$.

Um segundo desdobramento surgiu também sob os impactos de toda a crítica social aos rumos do desenvolvimento, tendo agora por foco a formulação de novas medidas e novas orientações capazes de fazer frente à desigualdade e à pobreza. O principal resultado deste esforço em ampliar o foco do debate sobre desenvolvimento, para além do crescimento econômico, foi a adoção, pelas Nações Unidas, da noção de desenvolvimento humano, que ganhou expressão mundial através do IDH - Índice de Desenvolvimento Humano. Embora seja comum associar o IDH ao nome do economista indiano Amartya Sen, seu principal formulador foi o paquistanês Mahbub Ul Haq. Em texto publicado no Relatório de Desenvolvimento Humano de 1999, Sen faz uma homenagem ao colega paquistanês pelo seu êxito em lograr construir um indicador sintético que cobre múltiplas dimensões da vida econômica e social de uma população e que conseguiu se impor como uma alternativa ao PIB como elemento mensurador do desenvolvimento, esta a principal ambição de Ul Haq. Mas pontua no mesmo texto seu ceticismo quanto à possibilidade de que um índice sintético possa de fato expressar substantivamente o desenvolvimento de uma dada sociedade, justamente

\footnotetext{
${ }^{33}$ Um caso que tem sido saudado como exceção, o Protocolo de Kyoto, ainda apresenta contornos e resultados previstos muito polêmicos para uma sentença mais segura ou definitiva. Para uma discussão mais aprofundada do estado atual do tema, consultar Veiga (2005).
} 
pela intrincada relação entre suas diferentes dimensões e pelo peso distinto que cada uma delas guarda em diferentes culturas.

Assim como no caso do movimento que envolveu a formulação da expressão "desenvolvimento sustentável", também na vertente do "desenvolvimento humano" o aspecto de crítica aos rumos do progresso teve mais alcance do que as iniciativas voltadas para a formulação de agendas positivas abrangentes. Mais que isso, muito pouco há de diálogo entre as duas vertentes, tanto em termos institucionais - o que se expressa nas estratégias diferenciadas de organismos internacionais como o Programa das Nações Unidas para o Desenvolvimento e o Programa das Nações Unidas para o Meio-Ambiente -, quanto em termos científicos - nada há nos documentos da Comissão Brundtland sobre as questões sociais, assim como nada há em Amartya Sen sobre a dimensão ambiental ${ }^{34}$. Ainda assim, em boa medida graças ao campo aberto por estas duas formulações, houve um deslocamento do campo gravitacional no leque de preocupações que perpassa a definição de políticas e instrumentos de desenvolvimento, de forma que, se não há consenso sobre as estratégias de conservação ambiental ou de diminuição da desigualdade e da pobreza, tampouco é possível engendrar qualquer iniciativa sem ter estes elementos em conta.

Por certo as idéias de "desenvolvimento sustentável" e "desenvolvimento humano" não esgotam as elaborações que se seguiram à associação entre crescimento, desenvolvimento, progresso. Entre as demais teorias e discursos um último campo de posições, ao mesmo tempo políticas e científicas, precisa ser lembrado: o dos chamados pós-desenvolvimentistas. Para este grupo o desenvolvimento não passa de uma invenção do mundo ocidental para dirigir as expectativas e os rumos das sociedades mais pobres. É nesse sentido que um de seus maiores expoentes, Gilbert Rist (2001) o define como uma "crença ocidental", e que Rahnema (1997) fala em "ilusão do mundo moderno"35.

Mas é importante distinguir a crença de Rist do mito de Furtado (1974), ou a ilusão de Rahnema do uso da mesma palavra em Giovanni Arrighi (1997). Enquanto para Rist a crença é algo desprovido de positividade, mero engano dirigido por um discurso emitido de uma posição dominante, em Furtado o mito é tratado como algo bem mais sofisticado, compatível

\footnotetext{
${ }^{34}$ É verdade que Amartya Sen publicou em 2002 um artigo devotado à questão ambiental e o futuro da humanidade. Mas não se pode, nem de longe, vislumbrar qualquer incorporação desta dimensão ou variável a seu esquema teórico.

${ }^{35}$ Outro nome importante entre os pós-desenvolvimentistas é Wolfgang Sachs (2000).
} 
com a tradição das ciências sociais de buscar nele o conteúdo sistematizador de uma concepção de mundo, de um todo coeso de valores que orientam o comportamento e a ação. Enquanto em Rahnema a ilusão é igualmente desvio do real, em Arrighi ela é a promessa que só pode ser alcançada por uns poucos, os que conseguem cruzar o fosso que separa o centro da periferia: não é realidade sem lugar, é lugar e realidade para poucos ${ }^{36}$.

O principal limite do discurso pós-desenvolvimentista está no fato de que ele pode até funcionar como um razoável elemento de crítica social ao papel das nações do núcleo central do capitalismo na disseminação de uma certa visão de como alcançar a melhoria das condições econômicas e sociais, mas nada diz sobre processos de desenvolvimento como resultado da evolução histórica de longo prazo. Como decorrência, esta perspectiva simplesmente não se aplica aos períodos anteriores ao domínio dos grandes países capitalistas do mundo moderno.

O que se tem, portanto, é uma multiplicidade de formulações teóricas, umas mais, outras menos consistentes, tentando ora evidenciar aspectos secundarizados nos processos e nas teorias do desenvolvimento, ora enaltecer determinados níveis de análise antes desprezados. Diferente daquilo que ocorreu no Pós-guerra, o final do século XX assistiu a uma explosão de significações sobre a idéia de desenvolvimento, onde à crise e à crítica social que se fizeram em torno dela, se seguiram tanto uma enorme polissemia, quanto tentativas de reconceituação. O que marca esse novo momento são dois aspectos: a idéia de desenvolvimento perde a adesão total e natural à idéia de crescimento, e mudam os portadores sociais das idéias sobre o desenvolvimento. Ela deixa de ser um monopólio da ciência e vai passar a freqüentar os discursos de militantes de movimentos sociais, de organizações não governamentais, de grupamentos políticos diversos.

Embora coexistam nos tempos atuais a crítica social, a polissemia, a explicação científica, não há dúvida de que são as perspectivas da crítica social e da ciência que travam o maior combate pois se polarizam, enquanto os polissêmicos bóiam ao sabor das críticas e das evidências alcançadas pelos outros dois pólos: para uns, o estágio atual da humanidade demonstra que evolução, progresso e desenvolvimento são várias definições do mesmo mito

\footnotetext{
${ }^{36}$ A obra de Arrighi, lançada no Brasil como $A$ ilusão do desenvolvimento, tem um título bem diferente no original inglês: Workers of the world at century's end.
} 
e apontam seus efeitos deletérios para as populações do "Terceiro Mundo"; para outros, tratase de encontrar as determinações capazes de explicar como as sociedades se desenvolvem e, ao entendê-lo, pensar os caminhos para que elas o façam de maneira a equacionar os elementos levantados pela crítica social.

Quais são as principais conclusões que esta breve gênese da idéia de desenvolvimento permite formular? De uma maneira tópica, pode-se sistematizar em algumas afirmações as principais implicações lógicas e teóricas. Primeiro, deve ter ficado claro que apesar dos problemas relacionados aos rumos tomados pela idéia de desenvolvimento, sobretudo no período áureo do capitalismo no meio do século passado, não é possível prescindir da necessidade de se pensar a evolução das sociedades humanas. A dissociação entre desenvolvimento e evolução é, como foi visto, algo que corresponde a um hiato na longa trajetória da idéia. Nesse sentido, abrem-se duas constatações importantes: desenvolvimento precisa ser compreendido não só como estágios ou etapas alcançados ou alcançáveis pelas sociedades humanas, mas como o processo mesmo pelo qual essa evolução se faz; além disso, essa evolução é algo que remete sempre a uma trajetória de longa duração. Como disse Elias (1970/1991: 184), o abandono dos problemas relativos às dinâmicas de longo prazo em benefício de problemas específicos e tidos como mais atuais foi resultado de constrangimentos bem específicos e típicos do século $\mathrm{XX}$, como resultado "on rejeta le bon grain avec l'ivraie". Talvez a principal constatação seja, pois, a necessidade de restabelecer os elos com esta tradição, rompidos desde os clássicos. Segundo, deve ter ficado claro também que nesta evolução contam diferentes dimensões: a dimensão do crescimento econômico, a dimensão das questões sociais, a dimensão ambiental, para ficar apenas nas três mais evidentes e mais enfatizadas. Estudos recentes têm procurado mapear a evolução de indicadores relativos a cada uma delas, e neste trabalho mesmo serão discutidas pesquisas e estudos onde este tipo de realidade é o objeto em questão. Mas o que explica sua ocorrência ? Para compreender a evolução e desenvolvimento das sociedades humanas é preciso compreender seus mecanismos de estabilidade e mudança e como estas diferentes dimensões interagem. É por isso que, uma vez elucidados alguns aspectos fundamentais relativos à trajetória da idéia de desenvolvimento e, principalmente, uma vez evidenciadas as instâncias empíricas fundamentais que precisam ser equacionadas por teorias que se pretendam elucidativas sobre estes processos, pode-se agora analisar especificamente as principais vertentes teóricas dedicadas a tais questões. 


\section{2-Qual teoria ?}

Se as bases científicas do desenvolvimento precisam dar conta da explicação dos fenômenos relativos à evolução de longo prazo das sociedades humanas, da estrutura e da mudança nestas sociedades, e se esta evolução comporta uma multiplicidade de dimensões, então obviamente o balanço das teorias disponíveis precisa se apoiar justamente sobre a capacidade das teorias em dar conta destes caracteres fundamentais. Como se sabe, todavia, a especialização dos campos disciplinares fez com que, para cada uma das dimensões destacadas - a dimensão do crescimento econômico, a dimensão social, a dimensão ambiental -, se formassem corpos teóricos específicos, com pouco ou nenhum diálogo entre si. Em face desta dupla constatação - as dimensões fundamentais a serem equacionadas e a ausência de teorias que tentem abrangê-las em seu conjunto - o percurso a ser seguido nas próximas páginas consiste em tomar separadamente teorias dedicadas a cada uma delas. Serão apresentadas e analisadas algumas obras exemplares em cada uma. Interessa aqui, particularmente, destacar o problema da mudança nas dinâmicas de longo prazo e o potencial de diálogo e complementaridade entre as teorias específicas de cada uma das três dimensões.

\subsection{1 - Desenvolvimento e crescimento econômico}

Um bom ponto-de-partida para o debate teórico sobre desenvolvimento e crescimento econômico é o apanhado das teorias consagradas à explicação da mudança de longo prazo em economia, formulada por Anderson (1991). Estão ali condensadas seis vertentes explicativas do crescimento econômico. Curiosamente o autor adverte logo na introdução que dentre estas seis correntes estão excluídas a teoria marxista e a weberiana, segundo ele por já terem sido suficientemente exploradas em outros trabalhos. A ausência de um debate mais sistemático, principalmente com a segunda destas vertentes, se mostrará, aliás, uma importante lacuna a ser preenchida.

A primeira das perspectivas tomadas por Anderson é aquela que identifica nos mercados o elemento-chave no estabelecimento das dinâmicas de longo-prazo, como nos estudos de Smith e Hicks. Mesmo reconhecendo seu vigor, o autor destaca com mais ênfase seus limites, marcadamente o fato de ser uma teoria capaz de iluminar apenas um momento histórico 
específico, aquele em que a livre-troca passa a ser predominante, sendo incapaz, portanto, de explicar o fenômeno do crescimento pré-moderno, igualmente importante. Isto é, o modelo só cabe para a análise de mercados perfeitos, os fatores históricos simplesmente não pesam na análise. A segunda vertente explicativa reúne os estudos em que a população é a variável chave, e que têm como principais expoentes, em correntes distintas, Malthus e Ester Boserup. Em ambos o ponto forte da explicação está no tratamento da variável populacional, a qual permite explicar tanto dinâmicas recentes como o passado remoto. Em Malthus, especificamente, sua teoria é construída totalmente em cima da pressão populacional sobre recursos limitados. Além do problema do pessimismo in extremis embutido na sua teoria, outra restrição que afeta seu alcance explicativo é a ausência de evidências que confirmem suas previsões. $\mathrm{O}$ argumento central de Boserup é simplesmente o inverso: quando há pressão demográfica há uma igual pressão pela introdução de inovações, fazendo crescer assim a produção de alimentos e permitindo a expansão da população. Em Boserup o problema é justamente a ausência de uma explicação para as razões que permitam explicar o crescimento populacional que está na origem da mudança tecnológica capaz de sustentar sua expansão, recaindo em uma explicação tautológica. Uma terceira vertente explorada por Anderson é aquela que destaca a tecnologia como variável fundamental, e que tem como um de seus grandes expoentes o nome de Schumpetter. O ponto forte das explicações apoiadas em tecnologia reside em que, nelas, se reconhece que a capacidade de criar e operar artefatos tecnológicos é o que diferencia o homem dos outros animais. Mas tecnologia só faz sentido quando acoplada a outra variável que permita substantivar suas causações ou seus efeitos para grupos humanos determinados. A quarta vertente reúne os estudos baseados na variável ambiental. Aqui a vantagem está na abertura que é propiciada para se lidar com um universo empírico mais abrangente que as trocas entre agentes, incorporando a natureza no rol de elementos passíveis de análise. Porém, os componentes ambientais aparecem mais como possibilidades para o estabelecimento de dinâmicas econômicas do que propriamente como determinantes. A quinta vertente se apóia na exploração como variável chave, tendo os estudos de Wallerstein como grande expoente. Nesse caso, um aspecto importante é a tomada do conflito - de um tipo específico de conflito, a exploração - como estruturante nas dinâmicas econômicas e, com isso, a quebra da visão linear de evolução das sociedades humanas. Para Anderson, contudo, a abertura que esta teoria traz para a explicação de realidades singulares restringe seu poder explicativo empurrando-a para uma retórica descritiva. Talvez isso valha para os estudos apoiados na idéia de exploração, mas não para 
aqueles estruturados em torno da idéia de conflito. A sexta e última vertente é aquela que aparece no balanço de Anderson como a mais completa para a análise da mudança econômica de longo prazo: a explicação institucional. Neste caso a questão relevante não é saber por que uma sociedade ou nação se desenvolve e outra não, mas sim porque algumas continuam crescendo enquanto outras não. A resposta institucional é que ali se criaram as instituições (regras do jogo) que motivaram a continuidade do progresso diminuindo os efeitos da ação dos rent-seekings. A explicação institucional parece ser a mais completa porque ela permite um diálogo que absorve, sem negar, os elementos explicativos de outras teorias: conflitos geram instituições, que formam sistemas de incentivos que dão origem a inovações, que por sua vez ensejam novos conflitos e assim sucessivamente. .

Partindo do balanço de Anderson, convém então uma análise mais detida da explicação institucional. E para isso, nada melhor do que focalizar os aspectos principais da obra de seu maior expoente: Douglass North.

\section{O pensamento de Douglass North}

A trajetória do pensamento de Douglass North pode ser sintetizada no movimento que envolve suas quatro principais obras. Na primeira, The rise of the western world, de 1973, North procura compreender a ascensão do mundo ocidental valendo-se para isto das ferramentas do mainstream econômico. Na segunda, de 1981, Structure and change in economic history, percebe-se já desde a introdução uma crítica à economia neoclássica e uma identificação de seus limites. Na terceira obra, Institutions, institutional change and economic performance, de 1990, North vai ainda mais longe e tenta formular a sua teoria, buscando, pois, ultrapassar os limites apontados no livro anterior. Na quarta e mais recente obra, Understanding the process of economic change, há novamente uma crítica aos limites da economia neoclássica e o anúncio de uma tentativa de completar o movimento feito nas obras anteriores, demonstrando como as diferentes sociedades constroem as infra-estruturas institucionais necessárias à boa performance. A pretensão de North, anunciada numa das passagens em que formula os desafios a serem enfrentados, é, portanto, construir uma ferramenta analítica capaz de teorizar a estrutura das economias e dar conta tanto da estabilidade como da mudança nestas estruturas ${ }^{37}$.

${ }^{37}$ Cf. North \& Thomas (1973); North (1981, 1990, 2005). 
Contudo, é bom advertir, o sucesso nesse intento do autor não é consensual. Ao menos duas leituras de North são possíveis. Uma primeira, como em Abramovay (2001), ressalta os elementos de ruptura, ou no mínimo de tensão, com a economia neoclássica: aqui são destacadas a introdução da história como parte fundamental do método, a incorporação dos atritos e conflitos sociais como dimensões explicativas da performance econômica, a indução como procedimento de análise. Uma segunda, como em Romeiro (2000), dá mais ênfase às permanências: apesar da tentativa de trazer história e conflitos para dentro do modelo, ainda seriam os preços relativos o que determina a mudança. O próprio North contribui para a confusão, à medida que em certos momentos enfatiza a ruptura, enquanto em outros aponta para o potencial desestruturador que a negação do homo oeconomicus representaria para a ciência econômica ${ }^{38}$.

Como tal ambigüidade é encaminhada na obra de North ? O objeto de suas reflexões é a história econômica, destacadamente dois momentos singulares: a primeira revolução econômica da humanidade, representada pelo surgimento da agricultura, aproximadamente dez mil anos atrás; e a segunda revolução econômica, representada pela associação entre ciência e processo produtivo nos fins do século XIX. Por revolução econômica North entende não só a mudança no potencial produtivo, tornada possível como conseqüência da mudança no estoque de conhecimento, como as condições de realização deste potencial produtivo. Para levar adiante sua empreitada, North considera ser necessário combinar elementos fornecidos pelas teorias da demografia, do estoque de conhecimento (tecnologia), e das instituições. Após um rápido balanço dos acúmulos e insuficiências nestes três terrenos, impossível de ser reproduzido aqui, o autor firma seus alicerces numa teoria dos direitos de propriedade, numa teoria do Estado, e numa teoria da ideologia. Na construção deste quadro analítico, as influências de North se fazem presentes através de elementos da escola neoclássica, do marxismo, e do cognitivismo ${ }^{39}$.

Iniciando então pela Revolução do Neolítico, a explanação em North começa com o fator demográfico. Mas diferente das teorias demográficas consagradas, que vão ora acentuar o caráter negativo da pressão populacional sobre recursos (como em Malthus), ora o caráter

\footnotetext{
${ }^{38}$ Velasco e Cruz (2002) traz vários trechos de obras e de entrevistas de North onde está ambigüidade está presente.

${ }^{39}$ Cf. especificamente North (1981).
} 
positivo (como em Boserup), na economia institucional a pressão populacional vai ser tomada como variável dependente da dimensão institucional. Isto é, enquanto em alguns lugares a pressão populacional levou a um esgotamento da utilização dos recursos disponíveis, com impactos negativos para os grupos humanos em questão, em outras situações a mesma pressão levou a encaminhamentos diferentes. Num desses encaminhamentos, o estabelecimento de direitos de propriedade sobre um dado território levou a um aumento da taxa de retorno pela aquisição de conhecimentos, traduzindo-se num incentivo à contínua exploração e ao crescente domínio sobre tais recursos. No modelo, direitos de propriedade mostram-se fundamentais não só para excluir outras populações e grupos humanos da posse e uso destes determinados recursos, mas para divisar regras que impeçam ou limitem a intensidade de sua exploração ${ }^{40}$. Sempre pensando em termos de ondas longas da evolução humana, gradativamente estas condições formaram a base para uma crescente especialização e divisão do trabalho. Com isso, além do enorme salto no potencial produtivo, teve origem também uma escalada igualmente crescente dos custos de transação, com um correspondente reforço dos direitos de propriedade e do Estado. A atuação do Estado em seus primórdios, diga-se de passagem, era dada pela fisiologia dos recursos em associação com a tecnologia militar disponível, influenciando assim a performance econômica não só através da redução dos custos de transação, mas também da expansão de mercados. Em North, portanto, não importa onde começou a agricultura, mas como e por que meios ela se tornou uma atividade fundamental, com impactos definitivos para o desenvolvimento da humanidade $^{41}$. E nisso, a idéia central está, repita-se, de um lado, no estabelecimento de direitos de propriedade, e de outro, em toda a dinâmica da crescente especialização e divisão social do trabalho que ele gera, em conflito com o aumento de custos de transação correspondente.

Os milênios que se seguem e que separam esta primeira revolução econômica da segunda, mais próxima de nossos dias, são palco de exemplos conhecidos de ascensão e declínio de grandes civilizações. Neste período, este é um dos destaques de North, houve, sim, crescimento econômico, mas na época antiga, sempre como decorrência da pressão

\footnotetext{
${ }^{40}$ Vale lembrar que a idéia de direitos de propriedade, em North, é bem mais ampla do que sua concepção usual moderna. Trata-se, antes, de uma definição que privilegia quaisquer formas que garantam a um determinado indivíduo ou agrupamento humano a exploração por sobre determinados bens, independente do estatuto pelo qual isso aconteça - jurídico, pela força, ou baseado em tradições e valores culturais.

${ }^{41}$ Para uma excelente análise do surgimento da agricultura e de seus posteriores desenvolvimentos até os dias atuais, consultar Mazoyer \& Roudart (1997/2002). Sobre a relação entre agricultura, crescimento e meio-ambiente, também segundo uma perspectiva de longo prazo, consultar Veiga (1997).
} 
demográfica. A inovação em sua análise está no fato de que ele explica este movimento destacando que a organização econômica eficiente é aquela que consegue criar os arranjos institucionais capazes de garantir: a) direitos de propriedade como incentivos aos ganhos de especialização; b) a redução dos custos de transação; c) uma convergência das taxas privadas e sociais de retorno ${ }^{42}$. Quando estas bases são abaladas tem início um movimento de desestruturação que torna estas sociedades mais e mais frágeis, até que encontrem o colapso e sua superação, não raro pela via da submissão a outra civilização ascendente. Assim foi com os fenícios, os egípcios, os romanos. E é assim que North mostra como muitas vezes a opulência e a riqueza de uma dada sociedade vem acompanhada de maior estratificação, a qual, com a passagem do tempo, pode dar margem a um esgarçamento do tecido social, a ponto de fazer pender a balança das taxas privadas e sociais de retorno, até sua derrocada. A alternância de civilizações é, assim, um longo movimento que acompanha a crescente especialização e divisão do trabalho, com o correspondente aumento tendencial nos custos de transação, que por sua vez leva à necessidade de adaptação das organizações econômicas. A explanação que começara com mudança populacional passa, assim, a se desenvolver sobre o intercâmbio entre oportunidades de mudanças econômicas e requisitos fiscais do Estado.

Uma nova mudança qualitativa no potencial produtivo e nas condições de sua realização vai acontecer com a associação entre ciência e processo produtivo já na época moderna. Como ela ocorre e por que tem início ali, na Inglaterra ? Porque ali, sempre segundo North, a ameaça de crise malthusiana que atingiu as demais nações naquele determinado momento histórico, somada ao acirramento das disputas comerciais intensas no período, encontraram uma determinada estrutura de direitos de propriedade, criada anteriormente, a qual fez reduzir custos de transação e, igualmente, fez crescer as taxas privadas de retorno em invenção e inovação, favorecendo assim a mudança tecnológica associada à revolução industrial e instituindo uma mudança qualitativa referente tanto ao potencial produtivo como às condições de sua realização.

Esta nova condição, por sua vez, não eliminou, mas sim acentuou ainda mais o movimento sempre crescente de especialização e custos de transação. Neste longo movimento histórico

\footnotetext{
${ }^{42}$ Também o conceito de instituições em North nada tem em comum com uma concepção formal, mais próxima de organizações. A definição simples de instituições como "regras do jogo" mostra como elas podem se instituir e operar seja em termos formais (como leis e dispositivos jurídico-políticos), seja em termos informais (como valores e tradições).
} 
de mudança incremental, que atinge um ponto máximo na segunda revolução econômica, as instâncias empíricas fundamentais com as quais North opera são população, tecnologia e ideologia, cuja dinâmica se materializa sempre em instituições políticas e econômicas. Para completar o quadro, é importante lembrar que o tratamento de "ideologia" aparece sempre no registro das "estruturas mentais partilhadas", em diálogo com o cognitivismo e como reflexo das estruturas de incentivos e constrangimentos sociais, nos quais o Estado desempenha um papel importante ${ }^{43}$.

Enquanto este desenvolvimento de longo prazo é a tônica do livro Structure and change in economic history, é em Institutions, institutional change and economic performance que North formaliza mais seu entendimento de mudança ${ }^{44}$. Ali ele lança mão do seu conceito de "path dependence" para explicar como a fonte da mudança incremental é a aprendizagem. A idéia central é que a dependência de caminho vem de mecanismos de retornos crescentes que reforçam a direção uma vez adotada, daí as resistências à mudança institucional. As "alterations in the path", por sua vez, vêm da não antecipação de escolhas, efeitos externos, e mesmo de forças exógenas ao quadro analítico. Esta é a dinâmica que molda a matriz institucional de cada sociedade. Matriz institucional entendida como a rede de constrangimentos informais e regras formais interconectadas que se traduzem em sistemas políticos, econômicos e jurídicos, os quais conformam e estabelecem a estrutura de incentivos que, por sua vez, em North, são o fator determinante a sublinhar na performance econômica.

Em Learning, institutions and economic performance, artigo que sintetiza algumas das principais idéias de seu mais recente livro, North volta a tomar a crítica à inadequação da economia neoclássica como ponto-de-partida ${ }^{45}$ : o pressuposto da escolha racional não teria fundamento empírico nem explicativo. Neste trabalho North aborda o aprendizado enquanto condição para compreender a mudança: como o aprendizado individual se transforma em aprendizado coletivo e como isto se relaciona com a emergência das instituições.

Nota-se, pois, o quão complexa, vigorosa e polêmica é a explicação de North. Basta sublinhar aqui apenas alguns dos aspectos ns quais ela inova a explicação da performance econômica: a) embora enfatize os direitos de propriedade, North desenvolve uma argumentação oposta ao

\footnotetext{
${ }^{43}$ Cf. North (1981).

${ }^{44}$ Cf. North (1990).

${ }^{45}$ Cf. Mantzavinos, North, Shariq (2003).
} 
laissez-faire, quando destaca o papel fundamental da regulamentação e do Estado na organização dos mercados, e não o contrário; b) em vez de imaginar a história da humanidade como sendo um esplendor de crescimento e riqueza somente nos últimos dois séculos, North mostra como houve períodos de crescimento intensivo mesmo nos primórdios da Antigüidade, e, mais que isso, que a mudança trazida com a associação entre ciência e processo produtivo é resultado incremental desta longa evolução; c) dadas as características desta segunda revolução econômica, nada leva a crer que a humanidade estaria vivendo um final dos tempos inaugurados por ela, e sim o contrário: em termos de mudança de longo prazo, os dias atuais - melhor dizendo, os séculos atuais - seriam apenas uma espécie de primeiros tempos de um novo e longo período; d) especificamente sobre mudança, sua fonte pode ser exógena como, por exemplo, pela via política, mas, para se sustentar, ela terá sempre que tocar na estrutura de incentivos e constrangimentos diminuindo custos de transação e favorecendo o crescimento e a convergência das taxas privadas e sociais de retorno.

Do lado das críticas, a principal já foi adiantada parágrafos atrás, e reside na identificação de uma ruptura apenas parcial de seu pensamento em relação à economia neoclássica, na qual ele tem origem ${ }^{46}$. Mas há, ainda, duas outras críticas que lhe poderiam ser endereçadas. A primeira delas está no fato de que, no limite, a explicação que sua teoria fornece também é tautológica: embora ela descreva com consistência como ocorreram as mudanças nas duas revoluções econômicas, o argumento para o porquê delas terem ocorrido quando e onde aconteceram é frágil: elas teriam ocorrido ali, porque ali estavam reunidas aquelas determinadas condições. Sobre isto, em defesa de North se poderia argumentar que o problema, na verdade, é inerente à inovação que seu pensamento propõe: em vez de um modelo dedutivo aplicável a qualquer realidade, é preciso recorrer aos mecanismos da indução para poder compreender a singularidade dos fenômenos em questão e estruturar esta compreensão na identificação de instâncias empíricas fundamentais e numa equação coerente para seu entendimento. A outra crítica diz respeito ao lugar da ideologia em sua teoria. População, tecnologia e ideologia e sua tradução em instituições políticas e econômicas são instâncias fundamentais do modelo proposto. Contudo, sempre que a ideologia (e os conflitos que ela envolve) aparece na explicação de North, tem-se a impressão de um tratamento menos incorporado à equação do que as outras duas instâncias. Isto é, a ideologia serve para

\footnotetext{
${ }^{46}$ Cf. Romeiro (2000). Ver também a crítica de Macedo (2001) à concepção de história em Douglass North. Sobre o uso da noção de path dependence segundo uma outra tradição, da ciência política, ver Pierson (2004).
} 
explicar aquilo que aparece como quase imponderável nas suas análises ${ }^{47}$. Um dos problemas que talvez explique este impasse está na concepção de homem que North preserva da economia neoclássica, compatível com o individualismo metodológico. Ideologia e conflitos aparecerão sempre no registro dos incentivos e constrangimentos à maximização dos ganhos individuais. Aqui, o diálogo do autor não se dá com as teorias sociológicas do conflito e das ideologias, mas com as teorias psicológicas. Algo compreensível quando se lembra da tradição das ciências econômicas americanas, mais próximas do cognitivismo e distantes das ciências dedicadas às estruturas sociais.

Este último aspecto não é mero detalhe, porque a concepção de homem da ciência econômica a aproxima da psicologia comportamental ao mesmo tempo e proporção que a distancia da sociologia. Isto faz com que se crie uma dificuldade em incorporar efetivamente as estruturas sociais no modelo e, também, um problema para ampliar a explicação econômica para além da esfera das trocas, incorporando o universo dos bens naturais. No modelo de North, a questão ambiental é tratada no âmbito do problema demográfico, portanto, dentro do que se poderia chamar de paradigma da escassez: ambiente é tratado como sinônimo de recursos naturais e sua importância explicativa está na direta relação com a pressão demográfica por sua utilização. É assim quando ele explica os colapsos das civilizações antigas, como esgotamento. É assim quando ele explica a pressão pela modificação dos direitos de propriedade sobre o uso da terra, no surgimento do capitalismo.

Uma das decorrências lógicas destes limites acima esboçados é a necessidade de se reportar às estruturas sociais sob uma maneira engenhosa, similar a Weber, onde a explicação não está nas estruturas, mas onde, ao mesmo tempo, é preciso incorporar as estruturas para entender o sentido das ações dos indivíduos e os conflitos a isso inerentes. Isto é, a ação pode se sobrepor à estrutura, mas não se desvencilhar dela. Porque para Weber as idéias não existem isoladas de sua articulação com interesses. Uma famosa passagem sua destaca que "não as idéias, mas os interesses (materiais e ideais) é que dominam diretamente a ação dos humanos. O mais das vezes, as 'imagens do mundo' criadas pelas 'idéias' determinaram, feito manobristas de linha de trem, os trilhos nos quais a ação se vê empurrada pela

\footnotetext{
47 Uma crítica que atinge também este aspecto, mas elaborada em uma direção um pouco diferente pode ser encontrada em Velasco Cruz (2002). Para Abramovay (2005), a relação entre ideologias e estrutura social vai ser feita por intermédio da psicologia, como estruturas mentais partilhadas, para usar a expressão de North.
} 
dinâmica dos interesses" ${ }^{\prime 4}$. E interesses têm portadores, assim como as idéias. Aqui entram dois conceitos não formalizados do pensamento de Weber que ajudam a entender estes nexos: portadores e afinidades eletivas ${ }^{49}$. Através destas duas expressões, presentes várias vezes em sua obra, Weber destaca como as idéias se estabelecem em consonância com determinados grupos ou estruturas sociais: como a ética das religiões orientais guarda estreita correspondência com as características da estratificação social; como as cidades, e não o campo, foram o terreno propício de expansão da religião sobre a magia; e como, finalmente, o cristianismo e, depois, o protestantismo nascem inicialmente nas camadas inferiores e médias da estrutura social de seu tempo. Fenômenos que, enfim, não poderiam ter ocorrido em outra formação social que não comportasse tais elementos, com os quais eles estavam em direta afinidade. É fácil notar, pois, a grande complementaridade que existe entre a obra de Weber e de North. E é curioso perceber como, não obstante este diálogo potencial, as menções ao sociólogo alemão na obra de North são tão esparsas e insípidas, aspecto que será retomado no balanço final desta seção ${ }^{50}$.

\subsection{2 - Desenvolvimento e a questão social}

Embora boa parte da crítica social à idéia de desenvolvimento esteja focalizada em sua redução ao crescimento econômico, não são muitas as teorias consistentes que procuraram compensar esta deficiência trazendo a questão social para o centro dos modelos explicativos. $\mathrm{Na}$ maior parte das vezes os discursos científicos deram origem a defesas de um igualitarismo entre os indivíduos sem, no entanto, lograr a edificação de uma verdadeira teoria onde esse desejo fosse ao mesmo tempo um pressuposto ético e um elemento operativo na explicação da evolução do real. Embora não seja exatamente um igualitarista, uma exceção honrosa é John Rawls e sua Teoria da Justiça, através da qual ele sustenta a necessidade de se estabelecer mínimos de igualdade de renda que deveriam ser garantidos a todos os indivíduos como condição para que estes, por si próprios, pudessem construir sua igualdade perante os

\footnotetext{
${ }^{48}$ Cf. Weber (1974).

${ }^{49}$ Esta idéia, de "afinidades eletivas" e de "portadores" como conceitos não sistematizados no pensamento weberiano é tomada emprestada de Antônio Flávio Pierucci, que a cogitou durante seu curso de Teoria Social na USP. Sobre o primeiro destes conceitos o autor tece alguns comentários no seu livro O desencantamento do mundo (Pierucci, 2003)

${ }^{50}$ Por exemplo, North critica Weber e tenta mostrar como algumas das idéias que ele associa à ética protestante teriam uma origem mais antiga, relacionada ao judaísmo e ao cristianismo. A leitura do conjunto da obra de Weber, no entanto, permite ver como ele estava atento a isso, já que a associação entre ética protestante e espírito do capitalismo é uma espécie de corolário de um longuíssimo processo de desencantamento e racionalização do mundo. O que prova como as convergências são, no mínimo, tão expressivas quanto as diferenças. Ver a respeito North (2005), Weber (1998).
} 
outros nos demais domínios da vida social - uma igualdade de patamares mínimos de renda como garantia de uma igualdade de oportunidades sociais.

Outro nome que se dedicou a formular teorias e análises onde a dimensão social, por assim dizer, está no centro das preocupações foi Amartya Sen. Como se sabe, Sen se consagrou por seus estudos sobre a fome em países como Índia, China, Bangladesh, mas também no Japão e na Irlanda, e mais recentemente em alguns países africanos. Mas ele se tornou mundialmente conhecido por sua assessoria a órgãos das Nações Unidas, num trabalho que culminou na formulação do hoje tão difundido Índice de Desenvolvimento Humano, e pela conquista do Prêmio Nobel de economia, em 1998.

Mais do que incorporar a questão social aos esquemas teóricos, o principal mérito de Sen é ter encontrado uma equação consistente para dois dos três dilemas fundamentais que envolvem desenvolvimento. Primeiro, se desenvolvimento não se reduz a crescimento, então quais são suas dimensões empíricas fundamentais ? Segundo, se são várias as dimensões, como elas se compõem ou conflitam, quais delas são um fim dos processos de desenvolvimento, quais são meios para atingi-lo ? Sobre o terceiro dilema é difícil responder cabalmente se houve um êxito tão grande como nos anteriores: a explicação da mudança em desenvolvimento. Sen, aliás, elege como interlocutores justamente os dois pólos apresentados até aqui: de um lado, ele irá se colocar em debate com aqueles que tomam desenvolvimento por crescimento econômico apenas; e de outro, com alguns dos críticos igualitaristas e com o próprio John Rawls. Por todas estas razões uma aproximação junto às principais bases de seu pensamento é simplesmente crucial.

\section{O pensamento de Amartya Sen}

O significado maior da obra de Sen, juntamente com a construção de uma outra maneira de se pensar o desenvolvimento, é a profunda contestação que ele produz acerca da mais cara tese do mainstream da economia, segundo a qual os indivíduos agem sempre motivados pelo auto-interesse. Para ele, não há evidências de que é o auto-interesse o que, exclusivamente, rege o comportamento. E, mais que isso, há fortes evidências de que "as deliberações éticas não podem ser totalmente irrelevantes para o comportamento humano real". Sentimentos como a solidariedade não podem ser desprezados em análises econômicas, sob pena de 
incompreensão do conjunto e da complexidade dos estímulos que regem o comportamento humano.

Assim, sua obra Sobre ética e economia (Sen, 1992) trata da ruptura epistemológica entre os dois domínios expressos no título - ética e economia -, para isso remontando a uma releitura dos clássicos, desde Aristóteles, para quem "a riqueza não é o bem que buscamos, sendo ela apenas útil e no interesse de outra coisa", até Smith e suas explicações sobre motivações e mercados. Desta retomada, Sen avança para o questionamento do conceito de eficiência, conhecido por "ótimo de Pareto": um estado ótimo no qual não se pode melhorar a vida de ninguém sem que se piore a vida de outro. Sen (1992) retruca afirmando que "identificar vantagem com utilidade nada tem de óbvio (...). Não é verdade que qualquer movimento que se desvie de um estado ótimo de Pareto para outro não-ótimo deva reduzir a utilidade agregada". Ou seja, seria possível que um indivíduo motivado por razões éticas abrisse mão de uma vantagem pessoal para que outro progredisse sem, com isso, ameaçar a eficiência econômica. E ele faria isso ao perceber que seria melhor para o conjunto da sociedade. O corolário é que, se a sociedade ganha, ele ganha também.

É, porém, em Inequality reexamined que o programa de Sen está melhor formulado. Ali ele retoma sistematicamente reflexões de outras obras anteriores suas, como o ensaio Desigualdade econômica, de 1973, e desenvolve quatro afirmações que o distanciam tanto dos que reduzem desenvolvimento ao crescimento quanto dos que enfatizam a diminuição da pobreza como o objetivo das políticas de desenvolvimento: desenvolvimento não se reduz a crescimento; uma das questões fundamentais é desigualdade; desigualdade de quê, se são várias então as dimensões que contam ?; e para concluir, a desigualdade de renda, de longe a dimensão privilegiada nas principais correntes, pode não ser a mais importante dentre as diferentes formas de desigualdade.

Logo no início do livro Sen define a tese. Pela precisão, vale a pena recorrer às suas próprias palavras: "A questão-chave para analisar e medir a desigualdade é: igualdade de quê ? Esta é a tese que eu pretendo desenvolver aqui. Eu mostrarei também que as éticas da organização social que resistiram à prova dos tempos têm, quase todas em comum, querer a igualdade de alguma coisa - este alguma coisa joga um papel fundamental a depender de cada quadro teórico respectivo. Não somente existe 'igualitaristas de renda' que querem as 
mesmas entradas de dinheiro para todos e os 'igualitaristas do bem-estar', mas os utilitaristas clássicos preconizando, eles também, que se acorde uma importância igual às 'utilidades' de todos, e os libertários puros que preconizam a todos uma classe inteira de direitos e de liberdades. Todos são igualitaristas sobre um ponto crucial: eles propõem resolutamente a igualdade de alguma coisa que todo o mundo deveria ter, e que é absolutamente vital em sua abordagem particular. (...) a questão 'igualdade de quê ' deve sua importância prática à diversidade de seres humanos: é por causa dela que a exigência de igualdade sobre uma variável tende a entrar em colisão - nos fatos e não somente em teoria - com a vontade de igualdade sobre outra. Pesam características internas (idade, sexo, atitudes gerais, competências particulares) e circunstâncias externas (propriedade de certos bens, origem social)". E mais adiante completa: “diversidade humana é fato, e a razão fundamental de nosso interesse pela igualdade (...). A idéia de igualdade se reporta a duas diversidades distintas: a heterogeneidade fundamental dos seres humanos, e a multiplicidade de variáveis em função das quais pode-se avaliar a igualdade. Por isso: igualdade de quê ?" (Sen, 1992/2000: 9-12).

Diante desta questão, como Sen constrói seu quadro de análise ? A idéia central é que a expansão das liberdades humanas é a um só tempo o fim e o meio dos processos de desenvolvimento. Essa é a grande definição de desenvolvimento cunhada por Sen e que lhe permite sair do unidimensionalismo e da armadilha representada pela oposição entre meios e fins. Para instrumentalizar analiticamente esta idéia, Sen vai se apoiar numa tríade de conceitos interligados - capacidades, funcionamentos e realizações (capabilities, functionings e achievements) - afirmando: "a abordagem em que eu me apoio se concentra sobre nossa capacidade (conjunto de modos de funcionamento humano que são potencialmente acessíveis a uma pessoa, quer ela os exerça ou não) de realizar os funcionamentos valorizados dos quais é feita a nossa existência e, mais amplamente, sobre nossa liberdade de promover os objetivos que nós temos razão para valorizar (...). A potência retórica da 'igualdade entre os homens' tem seguidamente tendência a desviar nossa atenção das diferenças. Se suas fórmulas (todos os homens nascem iguais, por exemplo) passam correntemente pelos pilares do igualitarismo, ignorar as distinções entre os individuos pode em realidade se revelar muito desigual". A estimação e a medida da desigualdade depende, assim, pesadamente, da escolha da variável - as rendas, a sorte, felicidade, etc -, e do que Sen chama de variável focal. A variável focal escolhida pode 
apresentar uma pluralidade interna. É possível, por exemplo, que ela reúna liberdades de ordens diferentes: elas constituirão juntas o centro do interesse privilegiado. Ou ainda, a variável retida pode associar as liberdades e as realizações - o que uma pessoa realiza, o conjunto dos modos de funcionamento que ela exerce verdadeiramente.

Concluindo, com a capacidade que qualquer um dispõe para realizar os funcionamentos que ele tem razões para valorizar, estabelece-se um ponto-de-partida bem geral para abordar o estudo dos modos de organização da sociedade, e esta démarche aporta uma maneira particular de conceber a avaliação da igualdade e da desigualdade (Sen, 1992/2000: 22). Os funcionamentos de que trata Sen podem ser os mais elementares - ser bem alimentado, escapar da morbidade evitável e da mortalidade prematura - até certas realizações muito complexas e sutis - ser digno a seus próprios olhos, estar em condições de tomar parte da vida da comunidade. A seleção e estimativa de diferentes funcionamentos permitem a avaliação da capacidade de realizar diversos conjuntos de funcionamentos, entre os quais é preciso escolher. A concentração sobre a liberdade de realizar e não somente o nível de realização visa a estabelecer a relação entre a estimativa das diversas realizações possíveis e o valor da liberdade de realizar. O corolário do pensamento de Sen vem com a afirmação de que o verdadeiro conflito se situa entre diferentes tipos de liberdade, e não entre liberdade e privação. (Sen, 1992/2000).

Em resumo, são duas as grandes aquisições propiciadas pela construção teórica de Amartya Sen. Primeiro, ao operar uma distinção entre capacidades e utilidades, com a focalização na capacidade de realizar os funcionamentos escolhidos pelos próprios indivíduos em sua diversidade, sua abordagem difere muito sensivelmente das abordagens mais tradicionais da igualdade, que se concentram sobre variáveis específicas, como a renda principalmente. Segundo, em sua teoria o desenvolvimento pode ser "aproximativamente mensurado", já que algumas das capacidades fundamentais dos seres humanos podem ser medidas e comparadas.

Um ponto nebuloso da teoria de Sen, contudo, diz respeito à mudança no desenvolvimento. Ao colocar a ênfase na expansão das liberdades ele reconhece que há um conflito na organização destas liberdades, em sua desigual distribuição, mas surge novamente aqui uma certa tautologia na cadeia explicativa. A expansão das liberdades é ao mesmo tempo um fim e um meio. Sendo assim, certas sociedades são pouco desenvolvidas porque nelas as liberdades 
são restritas e, inversamente, onde ocorre uma expansão das liberdades tem-se o desenvolvimento. Um exemplo pode ajudar a compreender melhor como isto acontece na teoria de Sen. Apoiado em Smith, ele mostra como o mercado - não raramente exorcizado e entendido somente como reforçador de desigualdades - pode ser algo progressista, por exemplo, nas situações em que o simples acesso de determinadas parcelas da população à possibilidade da livre concorrência contraria segmentos poderosos que se beneficiam das relações de tutela e clientelismo. Mas em Poverty and famines, onde introduz o conceito de entitlement (habilitação), Sen demonstra com clareza que o problema da fome epidêmica que ocorre em vastas áreas do mundo, num outro exemplo, não encontra solução simples no aumento da oferta, ou em simples mecanismos de mercado. Isso porque, para participar da distribuição da renda, é necessário estar habilitado por título de propriedade ou por inserção qualificada no sistema produtivo. Ora, há sociedades em que esse processo de habilitação está bloqueado: é o que se passa com as populações rurais sem acesso à terra, com populações a quem é negado o acesso a escolarização, ou com populações que com um mesmo grau de escolarização experimentam tipos distintos de experiência escolar. Logo, há um componente de conflito que não se esvai por simples e quase automática expansão de liberdades e que remete mesmo à necessidade de uma explicação para como se dá a mudança.

É verdade que Sen reconhece textualmente haver conflito em torno das privações e liberdades dos indivíduos, mas é verdade também que seu modelo não fornece elementos para explicar porque em certos lugares o processo de expansão das liberdades ocorre, e porque em outros ele permanece bloqueado. Não é que em sua teoria o conflito não está presente. Ele aparece na distribuição desigual das capacidades e nos atritos entre diferentes liberdades. E a distribuição desigual destas prerrogativas é a um só tempo condicionante e condicionado da expansão das liberdades. A mudança em Sen, portanto, ou é puramente incremental, ou se dá por variáveis exógenas ao modelo.

Um diálogo entre Sen e North mostra uma compatibilidade em pelo menos dois aspectos. Primeiro, quando ambos falam, um em expansão das liberdades, e outro em convergência das taxas privadas e sociais de retorno. A criação e, principalmente, a sustentação de um crescimento duradouro, em North, ou da expansão das liberdades individuais, em Sen, é um processo que dependeria desta não dissociação entre os ganhos individuais e os benefícios sociais advindos desta expansão. Nos dois há, contudo, uma lacuna, e este é o segundo 
aspecto similar: como se explica a mudança. Em North ela também é incremental ou exógena ao modelo. Em Sen o conflito aparece na distribuição das capacidades e nas diferentes liberdades. Não haveria incompatibilidade lógica em dizer que a expansão ou não das liberdades depende das instituições que operam em cada realidade específica, mas volta aqui o problema da determinação das instituições, como destacado no tópico anterior. No limite, novamente a explicação é tautológica. Daí a necessidade de uma ponte com as estruturas sociais do desenvolvimento.

O grande mérito destas duas abordagens está em que elas abandonam a idéia de tomar o desenvolvimento como um estado alcançável pelas sociedades e recolocam no centro do debate o processo pelo qual o desenvolvimento se faz: isto marca uma diferença tanto com os que reduzem desenvolvimento a crescimento quanto com os pós-desenvolvimentistas. No caso de Sen, como foi dito, isto se faz através da ênfase conferida a outras dimensões que não a riqueza, como também em sua inovadora maneira de pensar o desenvolvimento como fim $e$ como meio. No caso de North, a principal contribuição é mostrar como o processo de desenvolvimento é resultado de determinadas formas de coordenação, as quais sempre estão equacionando elementos estruturais como a relação entre demografia e o ambiente, a tecnologias, as ideologias e instituições políticas e econômicas, com destaque para o Estado. Em uma palavra, trata-se de duas abordagens que elaboram de maneira nova e apoiada em procedimentos inegavelmente científicos o problema do desenvolvimento. Nelas, todas as formas de reducionismo dão lugar a teorias complexas e multidimensionais nas quais a história ocupa um lugar central. Ao menos neste aspecto, elas representam uma desejável reconciliação com as concepções evolucionistas do século XIX.

\subsection{3 - Desenvolvimento e meio-ambiente}

As relações entre desenvolvimento e meio-ambiente têm sido crescentemente teorizadas nas diferentes disciplinas das ciências sociais.

No campo econômico, especificamente, pode-se dizer que o debate se polariza, embora não se esgote, entre duas abordagens: a da chamada "curva de Kuznets ambiental" (Grossman \& Kruegger, 1995), e a do "estado estacionário" (Daly, 1996). 
A idéia da "curva de Kuznets ambiental" é relativamente simples e consiste numa adaptação à questão ambiental da formulação que aquele autor elaborou para explicar a relação entre crescimento e distribuição de renda. Segundo esta teoria, produzida nos anos 50, a relação entre crescimento do PIB e a distribuição de renda piorava no momento de alavancagem de uma economia, mas tenderia a melhorar quando fosse atingido um determinado patamar per capita, dando origem a uma representação gráfica parecida com um "U" invertido, a curva de Kuznets. Apoiados em estatísticas disponíveis para problemas como poluição atmosférica urbana, oxigenação de bacias hidrográficas, e dois tipos de contaminação de águas, Grossman \& Krueger (1995) concluíram que a partir de um determinado patamar per capita, situado em torno de oito mil dólares, estes problemas começam a ser revertidos.

Apesar da pobreza da relação de causalidade expressa na hipótese da curva de Kuznets ambiental, é inegável que determinados conflitos podem encontrar maiores condições de solução em sociedades que gozam de maior poder financeiro. Um problema é a expansão de uma relação de causalidade direta para um conjunto de situações baseadas em estilos de crescimento e uso social de recursos naturais tão diversas. Um segundo problema consiste em esperar sabe-se lá quanto tempo para que a humanidade toda tenha um patamar de renda de oito mil dólares para que se possa, então, testar a validade da hipótese para os problemas ambientais globais.

Já a idéia do "estado estacionário" não é tão simples de ser explicada. Ela tem origem na física, mais especificamente na Lei da Entropia contida no Segundo Princípio da Termodinâmica. A idéia de um estado estacionário, na realidade, já estava posta desde os clássicos da economia, mas é com Georgescu-Roegen (1973) que ela ganha força, com a associação que ele promove entre a Lei da Entropia e a análise da questão ambiental. Duas idéias aqui são fundamentais. A primeira é que as atividades econômicas gradualmente transformam energia e, nesse processo, sempre há dispersão de energia; algo que se perde, que não se materializa em produto e nem é passível de reutilização. A segunda, é que este mesmo processo de produção gera rejeitos, os quais nunca poderão ser integralmente reciclados. No longuíssimo prazo, portanto, não haveria sequer forma de sustentabilidade plena possível. O que é possível, e este é o argumento central contido na idéia de estado estacionário, é atingir um determinado estágio de desenvolvimento, no qual o consumo 
baseado na expansão do produto possa dar lugar ao consumo de bens culturais e não materiais, retardando o colapso.

Aqui, o problema é saber quais as bases para esta transição. Georgescu-Roegen não aborda diretamente este problema, por considerar que o sentido contido na Lei da Entropia não poderia ser contornado. Mas um proeminente seguidor seu, Herman Daly, sim. E, infelizmente, sua resposta não é nada satisfatória. A seu favor, é preciso dizer que Daly admite que boa parte da humanidade ainda está longe de padrões razoáveis de vida. Sua proposta de adoção imediata de um outro estilo de desenvolvimento direciona-se às poucas nações que atingiram esses patamares. Mas, mesmo ali, o que levaria a crer que as pessoas estariam dispostas a abrir mão do consumo e da melhoria de seu conforto material em nome da preservação do meio-ambiente ? Sua resposta é que seria possível engendrar novos valores capazes de pôr fim à sanha consumista e individualista, por exemplo, através da religião (Daly, 1996). Outros não invocam a religião, mas o altruísmo e a educação ambiental para cumprir este papel de construir uma outra racionalidade (Leff, 1998). O problema está, pois, na percepção dos riscos ambientais e nas formas de seu encaminhamento, o que desloca o problema para uma abordagem propriamente sociológica.

No campo sociológico é a chamada sociologia do risco, representada na obra de seu maior expoente, Ulrich Beck, quem desenvolve a mais consistente formulação inserindo a questão ambiental nas condições específicas da modernidade. Em termos gerais, o que é a abordagem do risco ? O centro do argumento de Beck (1996) reside na identificação de uma mudança qualitativa no conflito inerente à condição moderna em seu período mais recente. Enquanto num primeiro momento a modernidade se estruturou em determinadas certezas - como a expansão das condições de vida (e, num interregno, com o pleno emprego), o progresso tecnológico e a confiança no conhecimento científico -, no momento atual elas teriam dado lugar a riscos globais expressos nas ameaças da militarização, nos problemas ambientais, nos direitos humanos. Na passagem de um a outro período estilhaçam-se os conflitos antes estruturados predominantemente em torno da oposição capital-trabalho, típicos da sociedade industrial, e passam ao primeiro plano estes conflitos globais que atingem diferentes classes sociais. Passa-se do progresso ao risco, das certezas à insegurança. A busca do "porto seguro" não estaria mais nas velhas instituições - como a ciência - mas sim num movimento de autoanálise da sociedade, num outro tipo de modernização, que o autor chama de modernização 
reflexiva $^{51}$. Nela, não há soluções ou caminhos cumulativos, mas a abertura para pôr sob suspeição toda forma de certeza e para a busca de alternativas minimizadoras destes riscos. Qualquer analogia com a o papel da psicanálise ante os conflitos dos indivíduos não é mera coincidência.

A questão ambiental aparece, em Beck, como um destes riscos globais, como um dos conflitos estruturadores da modernidade reflexiva. A separação entre natureza e sociedade é negada, à medida que há tempos a natureza foi socializada e à medida que a natureza do social foi internalizada na crise do padrão civilizatório. Tal como os demais conflitos, não caberia esperar sua resolução pelo domínio da técnica e da ciência, mas ao contrário, pelo domínio da sociedade ante os conteúdos da técnica e da ciência que incidem e operam com a natureza (Beck, 1996).

Aqui já é possível entrever alcances e limites da abordagem do risco ${ }^{52}$. Entre os aspectos positivos da abordagem está o fato de conferir ao problema ambiental um estatuto de maior importância, cujo tratamento certamente terá um peso crescente nos processos de tomada de decisão de agentes públicos e individuais. Junto disso, é positiva também a indicação de que se trata de um conflito que não obedece à lógica de oposições clássicas como capitaltrabalho. Mas é precisamente nesse ponto que surge a primeira insuficiência: o fato de não haver uma determinação de classe neste tipo de conflito não significa que não haja conflitos de interesses e que as posições relativas dos agentes na estrutura seja de menor importância. Como diz Lash (1997), uma suposição básica da modernização reflexiva é esta libertação progressiva da ação em relação à estrutura. Some-se a esta insuficiência uma contradição: a idéia do risco aposta na falência do estatuto fundante de instituições típicas da chamada sociedade industrial, como a ciência moderna e a razão, mas propugna uma resolução dos conflitos pela via do maior conhecimento e apreensão do real, fortemente tributária do Iluminismo e do racionalismo. Volta aqui não só o problema das instituições, mas também das estruturas sociais que influenciam sua formação.

Já no campo da geografia têm sido elaboradas interessantes análises onde os fatores ambientais entram como condicionantes das evoluções relativas a cada formação social. Isto

\footnotetext{
${ }^{51}$ Ver Giddens; Beck, Lash (1997).

${ }^{52}$ Para uma apresentação mais cuidadosa e uma análise da evolução das abordagens do risco, consultar Guivant (1998).
} 
já estava presente desde os primórdios da constituição deste ramo científico, no século XIX. Mas é nas obras recentes do biogeógrafo evolucionista Jared Diamond, a seguir tomada um pouco mais de perto, que se encontra a mais ampla aplicação da associação entre meioambiente e desenvolvimento numa perspectiva de longa duração.

\section{O pensamento de Jared Diamond}

Nos últimos anos dois livros de invejável densidade teórica e histórica foram publicados por Diamond. No mais recente - Colapso: como as sociedades escolhem o fracasso ou o sucesso -, o intuito é mostrar, como o próprio subtítulo indica, os caminhos que levaram ao longo dos tempos as várias sociedades a sucumbir por problemas derivados de crises ambientais ou, inversamente, como elas alcançaram soluções e alternativas que lhes permitiram corrigir rumos evitando tais desastres. O livro anterior, por sua vez, busca explicar a diferenciação espacial do desenvolvimento das sociedades humanas: nada mais, nada menos do que isso é a pretensão sintetizada nas quase quinhentas páginas do livro Armas, germes e aço - os destinos das sociedades humanas. Valendo-se de recursos da geografia, da biologia, e até da lingüística, entre outras especialidades, mas sem incorrer em grandes digressões teóricas, este autor transita por dez milênios de história e fornece uma explicação bastante coerente e consistente para sua questão, e que tem tudo a ver com as ponderações aqui levantadas. Para apresentá-la, nada melhor do que indicar, ao menos nas suas linhas gerais, o caminho percorrido pelo próprio autor ${ }^{53}$.

Na primeira parte do livro já citado, Diamond coloca uma pergunta que já fascinou muitos antropólogos: na conquista da América, o que fez com que um pequeno punhado de espanhóis derrotasse as forças incas, à ocasião muito mais numerosas ("168 esfarrapados espanhóis contra perto de 80.000 homens do exército inca", segundo seu relato) ? Por trás desta pergunta aparentemente simples, Diamond interroga na verdade as razões do domínio europeu ocidental sobre o restante do mundo. É certo que num primeiro momento, como já apontaram outras análises, houve um misto de temor e veneração diante da imagem desconhecida trazida com os invasores: suas armaduras, naus, cavalos. Mas não seria somente esta a razão do massacre. Afinal, logo após o espanto inicial, o embate se deslocou do terreno simbólico para outro bem mais palpável, com a captura do imperador e o violento

\footnotetext{
${ }^{53}$ Cf. Diamond $(2002,2005)$.
} 
embate físico entre os dois grupos. Aqui a explicação poderia se deslocar para uma resposta simples: a superioridade do armamento espanhol, o aço. Mas o autor não se contenta com a resposta fácil e, em meio a uma descrição complexa das múltiplas dimensões envolvidas naquela conquista - como, entre outras coisas, o efeito desagregador que a captura do imperador teve ante uma estrutura fortemente centralizada em seu personagem a um só tempo político e religioso -, Diamond recoloca a questão, remetendo para uma resposta que exige uma ainda maior profundidade histórica: por que, então, eram os espanhóis quem detinham a tecnologia do aço e seus usos, quando eram certas populações do Novo Mundo tão mais sofisticadas em uma série nada desprezível de aspectos ?

A segunda parte do livro explora justamente esta incógnita. Antes de passar a ela, é importante frisar que, ainda na primeira parte, Diamond começa por uma apresentação do estado do mundo desde que o homem se separa de seus ancestrais na árvore genealógica até um ponto situado mais ou menos treze mil anos atrás, com o intuito não só didático, mas metodológico mesmo, de mostrar como a espécie humana havia se espalhado pelo mundo e como, naquele instante, seu desenvolvimento se encontrava em estágios diferenciados nestas várias partes do mundo. Também nesta primeira parte do livro, o autor analisa como a geografia molda as sociedades humanas tendo por base um quase experimento de história natural: a formação das ilhas polinésias. Ali, um povo com a mesma origem biológica e partilhando de um mesmo rol de conhecimentos e valores, num dado momento de sua trajetória foi instado a povoar aquele conjunto diverso de ilhas. O que Diamond mostra é como, apesar destas condições iniciais similares, foi o ambiente diversificado que lhes moldou diferenciadamente o processo evolutivo, condicionando seus costumes, sua tecnologia, suas instituições políticas e econômicas. O cerne do seu argumento está na idéia de que condições ambientais mais restritivas para a condição humana em certas ilhas, por exemplo com menor disponibilidade natural de alimentos, teriam levado aquelas sociedades locais a um maior esforço no sentido de desenvolver tecnologias e criar instituições mais adequadas à tarefa de moldar esse meio às suas necessidades. O que Diamond tenta fazer na segunda parte do livro é exatamente extrapolar estas evidências apontadas pela experiência polinésia para a experiência da humanidade como um todo. Isto é, trata-se de mostrar como os condicionantes ambientais moldaram as trajetórias das sociedades humanas, engendrando elos e interdependências entre fatores como os germes - que certamente mataram mais 
populações nativas do que o aço -, a domesticação de grandes mamíferos, a cultura, a organização política, a tecnologia.

Assim, a segunda parte desenvolve este enfoque anunciado na primeira, tentando partir das causas imediatas, que possibilitaram o domínio europeu sobre os demais povos, em direção às suas causas históricas. E entre as causas históricas, diz Diamond, a produção de alimentos - mais que isso, as diferentes formas e tempos através dos quais as sociedades humanas se habilitaram à produção de alimentos - ocupa um lugar fundamental na cadeia explicativa. Enquanto alguns povos aprenderam sozinhos a cultivar, outros só o fizeram no contato com os que já detinham esta técnica. Enquanto algumas áreas apresentavam mais espécies e condições propícias para cultivo, outras eram mais restritivas. Com isso, ao mesmo tempo em que algumas áreas tornaram-se auto-suficientes, outras continuaram dependentes. Há, portanto, uma base biológica e ambiental que condicionou a evolução das sociedades humanas. Mas isto não é tudo. Por que esse condicionamento evoluiu numa certa direção em determinados lugares e em outra direção em outros quando se ampliaram as condições históricas para a disseminação das inovações alcançadas por determinadas sociedades ? A resposta é, novamente, ecológica e geográfica. O eixo leste-oeste da Eurásia favoreceu não só a propagação de culturas agrícolas e a criação de animais, face à relativamente baixa variabilidade de clima e latitude, mas também a propagação de inovações tecnológicas, devido ao caráter relativamente modesto das barreiras naturais. Já o eixo norte-sul nas Américas, mostrou-se um dificultador em ambos os aspectos e pelas características opostas.

A terceira parte do livro estabelece mais um elo na cadeia causal, mostrando como o estabelecimento de populações densas na Eurásia, possibilitada pelas condições já assinaladas, levaram à formação dos germes, a cuja exposição prolongada os povos do Velho Continente foram submetidos, com a criação dos correspondentes anticorpos, coisa que não ocorreu com as populações do Novo Mundo. Também nesta parte, Diamond retoma outro aspecto importante, este já mais conhecido das ciências sociais: a relação que a produção de alimentos teve para com o surgimento da escrita, das artes, das especializações e os desdobramentos que lhe são correspondentes, sobretudo em termos tecnológicos. A idéia básica está no simples fato de que a auto-suficiência em comida liberava estas populações da tarefa de caça e coleta, permitindo uma dedicação de tempo para especialidades outras, e, 
claro, para o sustento de elites políticas e militares que surgiam acompanhando este movimento de complexificação e hierarquização de sociedades e grupamentos humanos.

A quarta parte de seu livro emerge deste corte vertical na história para analisar as diferenças horizontais do mundo tal como o conhecemos. Mais uma vez amalgamando os conhecimentos de um leque variado de disciplinas através dos recursos da teoria evolutiva, Diamond irá responder a perguntas como: por que a África tornou-se negra ou por que a China tornou-se chinesa, passando por uma história da Austrália e por uma história comparada da América e da Eurásia.

Em síntese, são quatro os fatores apontados por Diamond como explicativos do destino das sociedades humanas: diferenças continentais entre as espécies selvagens de plantas e animais constituíram-se como as condições iniciais que moldaram os respectivos caminhos evolutivos; barreiras ecológicas influenciaram decisivamente no ritmo e no sentido de difusão e migração dentro dos continentes; barreiras ecológicas foram fatores que influenciaram igualmente na difusão entre os continentes; e a relação entre área e tamanho de população total, por fim, é fundamental para explicar não só a dinâmica populaçãorecursos naturais, mas para explicar as possibilidades de surgimento e expansão das inovações.

Um ponto inegavelmente importante está no fato de que ele consegue evidenciar as determinações ambientais para o desenvolvimento das sociedades humanas sem, no entanto, cair nos riscos do biologismo. É com esta perspectiva, aliás, que ele se põe em debate. O que Diamond tenta demonstrar é que não há nada de superior na constituição biológica de qualquer grupo de indivíduos humanos em relação aos demais. Que povos com a mesma constituição erigiram sociedades completamente diferentes. E que as razões são determinadas historicamente e ambientalmente.

A principal crítica que se pode fazer ao pensamento de Diamond está no fato de que ele concebe as sociedades humanas como agrupamentos que evoluem em resposta a estímulos e constrangimentos do meio-ambiente, não cabendo qualquer mediação com os processos mais propriamente sociais (sociológicos) que envolvem esta história. O autor reconhece esta crítica e argumenta como, em muitos casos, a estrutura social agiu como facilitador ou impedimento 
da disseminação de inovações importantes para o destino destas sociedades, como na China ou na Índia. Mas, ressalta ele, também aí, em última instância, a determinação será ambiental. E recoloca a questão: por que a China manteve por tanto tempo sua unidade enquanto a Europa se constituiu num mosaico de povos e culturas ? A resposta, como sempre, está nos fatores ambientais e geográficos: porque as características internas do território chinês facilitavam este domínio, numa oposição ao desenho cheio de penínsulas e ao litoral recortado europeu; e também porque a localização da China não lhe trouxe muitas vantagens de intercâmbio.

A segunda crítica diz respeito às possibilidades da mudança numa escala de tempo menor e, em particular, à idéia de que o peso das determinações do mundo natural teria diminuído em importância nos tempos modernos. Sobre isto a resposta de Diamond é enviesada. Ele reconhece a questão, mas vai assinalar o aspecto condicionante que os fatores ambientais tiveram no longo prazo e que hoje colocam povos e nações em condições desiguais. Algo que lembra a path dependence de North e seus desdobramentos para a explicação da desigualdade entre nações, mas pelo viés do condicionante ambiental. Fica portanto, em aberto, neste grande livro de Diamond, um diálogo mais direto sobre a possibilidade de mudança na condição específica da modernidade ${ }^{54}$.

No livro de 2005 - Colapso - Diamond dedica certas passagens da introdução a um diálogo com parte de seus críticos. Tendo sido bastante acusado de apelar para um determinismo ambiental, nesta nova obra o autor reitera várias vezes que as sociedades escolhem, e podem evitar as catástrofes ambientais. Enquanto em Armas, germes e aço a questão principal consistia em explicar as razões da supremacia européia nos tempos modernos, nesta nova obra Diamond se propõe mostrar porque, ao longo do último milênio, determinadas sociedades desapareceram, enquanto outras permaneceram. Ele elenca cinco fatores que podem contribuir para que ocorram ou não colapsos ambientais: dano ambiental, mudança climática, vizinhança hostil, parceiros comerciais amistosos, e respostas da sociedade aos problemas ambientais. É curioso notar que são dedicadas aproximadamente quatro páginas para os primeiros fatores, de ordem ambiental. Já para a explicação do quinto fator, após a indicação de alguns exemplos onde se adotaram soluções que levaram ao fracasso ou ao

\footnotetext{
${ }^{54}$ Embora não trate especificamente da obra de Diamond, uma crítica às abordagens da mudança de longo prazo centradas na dimensão ambiental pode ser encontrada em Anderson (1991).
} 
sucesso, como representado respectivamente pelo caso da Groenlândia e do Japão, Diamond pergunta: como compreender resultados tão diferentes ? A resposta, segundo ele, é que tudo depende das instituições políticas, econômicas, sociais e dos valores culturais de cada sociedade. E passa adiante. O exame dos casos descritos ao longo do livro não permite enxergar uma estrutura explicativa específica para como surgem estas instituições. Nem por isso a contribuição de Diamond é menos importante. Mas revela uma lacuna que precisa ser preenchida.

Quem não recua diante de tão complexo desafio é Jane Jacobs, urbanista e autora de livros consagrados como Vida e Mortes das grandes cidades e, mais recentemente, de uma obra cujo título diz muito sobre seu viés de abordagem: A natureza das economias. Para ela, desenvolvimento é uma versão, uma forma do desenvolvimento natural. A essência de seu argumento talvez possa ser resumida na afirmação de que as sociedades, e as economias mais especificamente, se tornam dinâmicas e se desenvolvem quando são capazes de promover variadas e intricadas interações, e assim criar vigorosamente diferenciações a partir daquelas já existentes. Por isso diversificação é uma palavra-chave: ela amplia a possibilidade de interações entre as partes do sistema, seja ele um sistema natural, um sistema de cidades, uma economia local. Possibilidades de interação e inteligência criativa fazem estas combinações se tornarem novas generalidades, da qual irão se tornar possíveis novas combinações, novos co-desenvolvimentos, e assim sucessivamente, numa dinâmica de constante criação, diversificação e evolução (Jacobs, 2001). O desenvolvimento teria, assim, um movimento geral, um sentido, e uma lógica que é a mesma que vale para os fenômenos naturais e sociais. Esta tese de Jacobs é, portanto, útil para pensar o desenvolvimento, em geral, e será particularmente importante quando se for analisar desenvolvimento rural, em particular, já que uma das mais importantes obras da autora trata justamente das relações entre cidades e os campos na produção da riqueza (Jacobs, 1984).

Esta idéia de diversificação merece ser retida. Os problemas na teoria de Jacobs começam justamente quando ela atribui à dinâmica econômica, evolutiva, um naturalismo. Se fosse possível enxergar alguma uniformidade nos processos de desenvolvimento sua explicação seria suficiente. O problema é que seu modelo teórico simplesmente não permite analisar a diferença, a desigualdade. Tudo se passa como se, naturalmente, diferenciações emergissem de generalidades, das quais surgiriam novas diferenciações. Mas por que determinadas 
generalidades dão origem a certos tipos de diferenciações ? Isto não pode ser explicado somente pelos condutos de energias, nem por qualquer determinação prévia inscrita na configuração anterior. As configurações explicitam campos de constrangimentos e de possibilidades, mas não o sentido em que se estabelecerá sua dinâmica.

Assim como na crítica feita a Sen, seria preciso aqui introduzir um elemento explicativo que desnaturalize a explicação, e que confira às estruturas sociais algum papel. É claro que Jacobs reconhece que as diferentes possibilidades de realização da criatividade das pessoas não são plenamente liberadas, não são livres de condicionantes. O problema está em que, o que explica a evolução do real é justamente por que mecanismos a criatividade inata aos seres humanos não se realiza plenamente, e não o potencial nela contido. $\mathrm{Ou}$, em outros termos, o que é explicativo não é o inato, mas o que impede o potencial, o inato, de se realizar, ou o que o canaliza em diferentes direções. É justamente isso que fazem Mazoyer \& Roudart (1997/2002) em sua história das agriculturas do mundo: ali o meio-ambiente é uma instância tão determinante quanto o são os conflitos ou a tecnologia. Neste livro que também aborda a longa evolução de sociedades humanas, a natureza entra como elemento explicativo, sem apagar os determinantes sociais do apogeu e declínio das grandes civilizações, mas também sem subordinar-se completamente a estes determinantes. 


\section{Síntese do Capítulo 1}

Embora não exista dúvida de que a maior parte das definições disponíveis sobre desenvolvimento tenha como traço comum seu viés eminentemente normativo, a retomada da longa trajetória desta idéia mostra que nem sempre foi assim. Numa outra vertente, cuja validade científica não pode ser questionada, o desenvolvimento de uma sociedade pode ser compreendido como evolução de uma configuração histórica determinada. Evolução que nada tem de linear, e que pode se dar em diferentes direções, aproximando-se ou distanciando-se do ideal contido no projeto normativo do desenvolvimento como melhoria dos indicadores econômicos, sociais e ambientais de um dado país, região ou grupo social.

Compreender nestes termos os processos de desenvolvimento leva necessariamente à constatação da insuficiência dos aparatos teóricos a eles dedicados. As teorias de maior apelo pecam ou por desconsiderar a importância do estoque de bens e recursos de que uma sociedade dispõe para estabelecer fluxos dinâmicos - recursos que linhagens bem distintas do pensamento social e econômico vêm chamando por capitais, social, humano, cultural, e até natural -, ou por não explicar de onde vêm as instituições que lhes permita compô-los de uma maneira a alcançar mais bem-estar e coesão social. Daí a necessidade de observar as articulações entre meio-ambiente, estruturas sociais e instituições, aspectos geralmente enfatizados de maneira isolada por tradições disciplinares concorrentes como a geografia, a sociologia ou a economia. 
PARTE II

RURALIDADE 


\section{Capítulo 2 - Ruralidade}

A idéia de desenvolvimento rural é algo que envolve a manifestação de um processo de características mais gerais, o desenvolvimento, em um domínio específico, neste caso o rural. Compreendê-lo sob uma perspectiva não normativa é algo que exige a adoção de dois procedimentos. O primeiro é o que se depreende da Parte I, anterior: é preciso entender o desenvolvimento não como desejo ou utopia, pelos conteúdos expressos num "dever ser", mas como evolução de configurações sociais determinadas, analisando as interdependências entre meio-ambiente, instituições e estruturas sociais a partir de um enfoque

de sua trajetória em longo prazo. O segundo procedimento é justamente o que enseja esta Parte II: definir em que consiste a particularidade deste tipo de espaço que é o rural. Nos tempos recentes tornou-se quase um hábito acrescentar o adjetivo "novo" para tratar da qualidade do rural no mundo contemporâneo. Fala-se em "novo rural", em "novas ruralidades", muitas vezes sem um maior esforço analítico em elucidar o que neles é recente e o que é propriamente permanente. Importa, sobretudo, saber qual a implicação desta nova situação, insinuada pela adjetivação crescentemente vista na bibliografia sobre estudos rurais, em termos de instâncias empíricas fundamentais e de articulações conceituais para entendêlas. Uma opção que, além disso, se impõe também pelo teor da tese que se pretende demonstrar: a afirmação de que os rumos atuais dos processos de desenvolvimento em áreas rurais e os esforços cognitivos para compreendê-los, sobretudo aqueles presentes no âmbito da chamada abordagem territorial, representam um dépassement do paradigma agrário, dominante nas ciências sociais aplicadas aos estudos rurais.

Os dois capítulos que compõem esta Parte do estudo tomam a oposição campo-cidade, ruralurbano, como ponto-de-partida, para superá-la em vez de negá-la. Para isso, este Capítulo 2 traça uma pequena história desta relação. Através das contribuições de grandes historiadores como Fernand Braudel, Georges Duby, Paul Bairoch e de Max Weber, pretende-se ressaltar como a evolução destes dois espaços não pode ser compreendida senão em termos de suas interdependências. Nesta trajetória, são abordadas as especificidades que marcam tanto a heterogeneidade espacial da urbanização em termos históricos e geográficos gerais, como especificamente a América Latina e suas peculiaridades. O ponto-de-chegada é a interrogação em torno das mudanças atuais e o que elas significam perante a trajetória de urbanização 
crescente. Enquanto neste capítulo pretende-se reter o que há de profundo e de persistente na evolução da configuração destes espaços, no Capítulo 3 seguinte, que completa esta parte do estudo, o intuito será pôr em relevo a natureza e a variedade das funções e mecanismos que respondem pela dinâmica atual dos espaços rurais. Como se trata de analisar os efeitos da intensa urbanização das últimas décadas para a relação entre o rural e o urbano, o objeto privilegiado será então a realidade dos Estados Unidos e da Europa, justamente por ser ali que tal fenômeno foi às suas últimas conseqüências conhecidas.

As duas próximas seções são, portanto, guiadas por uma pergunta: aquilo que vem sendo chamado por "novo rural" ou "nova ruralidade" representa, de fato, um novo momento na trajetória evolutiva dos espaços rurais ? Estas páginas têm a pretensão de mostrar que a resposta a esta questão é afirmativa, e trazem também uma tentativa de delinear os contornos fundamentais deste novo momento e algumas de suas implicações teóricas.

\section{1 - Pequena história da relação campo-cidade}

A idéia de rural, ou de ruralidade, é similar a tantas outras que só existem em relação direta com seu par oposto, tal como acontece com o masculino e o feminino, ou com o sagrado e o profano. Para pensar os termos da relação entre os dois pólos a primeira dificuldade que se impõe é justamente sua própria delimitação.

$\mathrm{Na}$ economia rural, a tradição sempre foi pensar seu objeto como algo relacionado à agricultura, no mais das vezes incorporando aspectos que vão além daqueles diretamente relacionados à produção primária, mas tendo por universo as famílias ou empresas ligadas a esta atividade. É evidente que isto teve durante determinado período uma base histórica, uma correspondência no real que lhe sustentava, mesmo que como visão distorcida ou parcial: o peso determinante do setor agrícola na vida rural.

$\mathrm{Na}$ sociologia, a própria criação do ramo dedicado ao rural veio apoiada na oposição comunidade-sociedade, restringindo seu objeto ao estudo das várias dimensões da vida social dos pequenos lugarejos, também com forte presença da agricultura na determinação dos rumos dos indivíduos ou das economias locais, e sempre pensando esta esfera com uma relativa autonomia e em aberto contraste com a sociedade envolvente. A clássica definição de 
Sorokin elenca os seguintes traços marcantes: as diferenças ocupacionais entre os dois espaços, com maior peso das atividades primárias no caso dos espaços rurais; as diferenças ambientais, com maior dependência da natureza no rural; o tamanho da população; a densidade demográfica; o grau de diferenciação social e de complexidade; as características de mobilidade social; e as diferenças de sentido da migração ${ }^{55}$. São traços que claramente falam mais da condição rural nos anos 30 do século XX, quando tal definição foi formulada, do que exatamente de caracteres fundamentais da ruralidade ${ }^{\mathbf{5 6}}$.

O estudo da história urbana, da história das cidades, por sua vez, rendeu periodizações e tipologias interessantes, que partem de alguma definição do que pode ser considerado, em perspectiva de evolução temporal, uma cidade. Paul Bairoch, num livro clássico sobre o tema - De Jerico a México: villes et économie dans l'histoire (Bairoch, apud Bairoch, 1992) elenca cinco critérios mais comuns para se considerar um assentamento humano determinado como uma cidade: existência de um artesanato em tempo integral, indício de especialização de tarefas; existência de fortificações por oposição a aldeia, que permanece aberta; tamanho e sobretudo densidade populacional; a estrutura urbana de habitação (casas, ruas, etc); e a durabilidade da aglomeração em oposição ao acampamento.

Bairoch adverte que dependendo da região em questão alguns destes critérios podem perder o sentido estruturante. De todos, a presença do artesanato é o mais importante, por sua relação com a especialização e o que ela implica para a divisão do trabalho e a necessidade e possibilidade da troca. Esta conceituação sustenta uma cronologia de longa duração da relação entre campos e cidades. Nesta sua história econômica o autor estabelece uma periodização estruturada em quatro etapas: os primórdios da urbanização (5000 a.C.); as sociedades tradicionais (de 2700 a C. à Revolução Industrial); a Revolução Industrial (da Revolução Industrial ao Pós-guerra); e finalmente o período marcado por aquilo que ele chama de "inflação urbana no Terceiro Mundo".

Já Max Weber, em A dominação não legítima (Tipologia das cidades), havia adotado critérios de definição e classificação das cidades que aliam aos critérios por ele mesmo definidos como "estritamente econômicos" e "político-administrativos", outros de ordem

\footnotetext{
${ }^{55}$ Cf. Sorokin, Zimmerman e Galpin (1986).

${ }^{56}$ A respeito da constituição deste ramo disciplinar e das injunções sociais a que ele estava exposto neste momento, ver Martins (1986).
} 
“associativa" (Weber, 1998: 408-409). De acordo com esta idéia, sob o aspecto estritamente econômico, a existência de uma cidade implicava: ter uma sede senhorial-territorial com centro, para o qual deveriam convergir as demais atividades; a troca regular de bens como componente essencial das atividades aquisitivas; ser um lugar que comporte um mercado, onde a população local satisfaz uma parte essencial de suas necessidades cotidianas. Sob o aspecto político-administrativo, a cidade constituiu-se historicamente como uma unidade entre mercado, como decorre das funções descritas, e fortaleza, guarnição, sede administrativa de uma determinada abrangência ou domínio. Nestas condições, as cidades se caracterizaram fisicamente por serem assentamentos fechados, em oposição a ocorrência de moradias isoladas, e por serem grandes assentamentos humanos e não pequenos, onde predominam os laços de conhecimento pessoal. A estes dois aspectos Weber agrega o elemento associativo, o que em sua teoria significa mais do que a espontânea ou induzida combinação entre indivíduos numa mesma empreitada ou organização, significa mesmo o próprio processo de "as-sociação", de viver em sociedade ${ }^{57}$. E nisso Weber destaca a necessidade de existência de uma "comunidade urbana", da qualificação de cidadão com as liberdades e direitos que isto comporta, mas, também, com os constrangimentos nisto implicados, tal qual existiu originalmente somente no Ocidente.

No pensamento do grande sociólogo alemão, e de maneira coerente com seu método dos tipos ideais, em vez de uma cronologia tem-se uma tipologia, onde a ênfase no tipo de agentes por detrás dos processos sociais predominantes dá origem às típico-ideais cidades de consumidores, cidades de produtores, cidades mercantis e cidades de agricultores, com vários destes tipos coexistindo em períodos históricos determinados ${ }^{58}$.

Um diálogo entre estas definições sugere que uma abordagem da história das relações entre campo e cidade deveria combinar a composição de critérios estruturais e funcionais com critérios relacionais, através de um tratamento da longa duração da contradição entre os dois pólos. É isso o que faz Georges Duby (1973) analisando a situação européia e francesa em particular, até chegar a uma tipologia da interação destes espaços. Ou Fernand Braudel

\footnotetext{
${ }^{57}$ Ver a respeito a elucidativa explicação de Gabriel Cohn na sua introdução à edição brasileira de Economia e Sociedade (Weber, 1998).

${ }^{58}$ Os tipos ideais são um recurso elaborado por Weber para contornar os limites do pensamento indutivo em ciências sociais. Eles nunca existem enquanto tal no mundo real. São construções teóricas, obtidas a partir da acentuação de um ou mais dos caracteres fundamentais das realidades em questão, e servem como uma medida aproximativa, a partir da qual pode-se avaliar o quão próximo ou distante determinada situação está do tipo ideal e, em seguida, interrogar as razões para tanto. Para um tratamento mais pormenorizado ver Ringer (2004).
} 
(1979/1995, 1985) que em sua obra clássica confere às cidades - sempre tomadas em relação com os campos - o mesmo estatuto dado à moeda na evolução histórica da Civilização material e capitalismo: ambos são fundamentais para a ampliação das trocas. E, como diz Braudel, "sans échange, pas de société".

Nesta longa evolução, cabe perguntar, portanto, o que são os traços distintivos em uma e outra época e, principalmente, o que tal trajetória ensina a respeito das características fundamentais e das possibilidades de desenvolvimento rural no mundo contemporâneo.

\subsection{1 - Dos primórdios da divisão espacial do trabalho à modernidade}

A relação com o que muito mais tarde a humanidade viria a chamar como campos e cidades começa pela própria essência do nascimento do fenômeno urbano: a formação dos primeiros assentamentos de caráter mais permanente a partir da Revolução do Neolítico, com a passagem da colheita, caça e pesca para agricultura e a criação. Não se trata de entrar aqui na polêmica que já consumiu rios de tinta entre os especialistas no assunto sobre quem determinou o quê na relação entre a sedentarização e a criação das práticas agrícolas, mas de destacar que o aumento da produção por superfície de terra teve conseqüências maiores para a história posterior da humanidade na formação de excedentes intercambiáveis e no adensamento populacional associado ao fim do nomadismo ${ }^{59}$.

Para se ter uma idéia do alto grau de interdependência entre estas duas variáveis, basta lembrar que, para a situação da Europa no Pré-Neolítico, seria necessária uma área equivalente a "cinco Suiças ou uma Grã-bretanha" para suportar uma cidade de mil habitantes, o que tornaria impossível se estabelecer fluxos de troca (Bairoch, 1992). Por isso não é de se espantar que raras foram as regiões onde, havendo agricultura, não se formaram cidades no curso dos dois mil anos seguintes. Quanto mais volumosos os excedentes agrícolas, quanto melhores as terras, mais precoce foi o surgimento de assentamentos humanos importantes, como mostra o quadro a seguir.

\footnotetext{
${ }^{59}$ Há uma literatura relativamente extensa a respeito. Consultar, entre outros, Boserup (1987), Mazoyer \& Roudart (1997/2002), North (1981).
} 


\section{Quadro 1 \\ Indicações de prática agrícola e surgimento das cidades - comparação temporal e espacial}

\begin{tabular}{|l|l|l|}
\hline \multicolumn{1}{|c|}{ Região do mundo } & $\begin{array}{c}\text { Primeiras indicações de prática da } \\
\text { agricultura }\end{array}$ & \multicolumn{1}{c|}{$\begin{array}{c}\text { Primeiras indicações de cidades proto- } \\
\text { urbanas }\end{array}$} \\
\hline Oriente-médio & $8500-8000$ a.C. & 7800 a.C. (Jericó) \\
\hline Ásia & $6000-5000$ a.C. & $\begin{array}{l}2000 \text { a.C. (India) } \\
1500 \text { a.C. (China) }\end{array}$ \\
\hline América & $7000-6500$ a.C. & $1500-800$ a.C. \\
\hline Europa & $6500-6000$ a.C. & 2500 a.C. \\
\hline África & 5000 a.C. & $1000-500$ a.C. \\
\hline
\end{tabular}

Fonte: Bairoch (1992)

Esta dependência direta foi chamada por Bairoch de "dupla tirania, da distância e da agricultura". As possibilidades de desenvolvimento eram totalmente presas à possibilidade de produção de bens de subsistência através da atividade primária. E as eventuais trocas estavam igualmente vinculadas ao êxito em se alcançar um excedente. Seu intercâmbio, por sua vez, estava igualmente atado à extensão da distância entre os locais de origem dos dois pólos envolvidos, já que não existiam condições de transporte e conservação mínimas.

É evidente que a dinâmica que envolve estes números e esta relação entre agricultura e formação das cidades é algo que implica em intervalos temporais bastante dilatados, como fica claro no quadro apresentado. E não é por acaso o uso da expressão "assentamentos humanos" e não cidades. Bairoch qualificou as primeiras formações de "cidades protourbanas", pois elas já se distinguiam claramente das aldeias do Neolítico. Enquanto estas eram formadas por assentamentos envolvendo de quinze a trinta casas, num total de duzentas a quatrocentas pessoas, as primeiras cidades do Oriente Médio, por volta do ano 2700 a.C., reuniam entre sete a vinte mil habitantes. Ali já havia uma especialização mais intensa e tem início uma verdadeira Revolução Urbana, tornando possível desde então falar verdadeiramente em cidades, com as características que lhes são típicas. Estima-se que a população mundial neste período já era de algo entre quarenta a noventa milhões de 
habitantes, dos quais apenas um a dois milhões habitando nas cidades. No período entre 1730 e 1690 a.C., a Babilônia, um dos mais importantes centros da Antigüidade, comportou entre duzentos e trezentos mil habitantes. E no auge do Império Romano, sua capital chegou à impressionante casa do um milhão de habitantes, momento em que o mundo inteiro comportava pouco mais de cento e cinqüenta milhões de pessoas. Após o declínio romano, deslocou-se para a China e o mundo muçulmano a concentração das cidades com mais de cem mil pessoas. Passou-se quase um milênio para que a população mundial dobrasse de tamanho, alcançando a casa dos duzentos e cinqüenta milhões de pessoas por volta do ano 1000. Depois, em apenas cinco séculos este número dobrou novamente, e chegou a quinhentos milhões em 1500. Em 1700 a população mundial já havia saltado para algo em torno dos setecentos milhões de pessoas, dos quais sessenta milhões habitando as cidades. Neste momento da história, a Ásia tinha trinta e três cidades com mais de cem mil, enquanto a Europa tinha apenas doze. Mas nesta última, embora o número de citadinos tenha se multiplicado por cinco, o número de cidades de cinqüenta mil habitantes havia se multiplicado por quinze (Bairoch, 1992), denotando um padrão bem diferente daquele experimentado no Oriente e revelador da especificade européia, traço tão destacado por Max Weber.

Segundo ele, foi justamente na Europa que a intensidade das ações das cidades sobre os campos foi mais positiva para o conjunto da economia, porque foi ali, naquele continente ou em uma parte específica dele, que as cidades se constituíram em espaços de associação menos vinculados às qualificações estamentais que pesavam sobremaneira nos campos. Weber dedicou uma extensa pesquisa materializada em vários de seus textos para explicar as articulações entre idéias, economia e sociedade ${ }^{60}$. Sua abordagem é compreensiva justamente por não conferir uma determinação única do material para as instituições ou vice-versa, e sim por ver o real como resultado de composições históricas singulares. Enquanto no Oriente as cidades se firmaram como extensão dos domínios de castas e estamentos religiosos, no Ocidente elas tomaram a forma de espaços de troca mais dinâmicos.

\footnotetext{
${ }^{60}$ Para o debate aqui proposto são de extrema importância os seguintes textos de Weber: o capítulo intitulado Sociologia das religiões e a seção Tipologia das cidades, ambos em Economia e Sociedade; e a Parte III: Religião, dos Ensaios de Sociologia, além d'A ética protestante e o espírito do capitalismo. Cf. respectivamente Weber (1998; 1904/2004). Uma excelente apresentação dos textos sobre religião, discutida a partir de sua importância para o processo de desencantamento e racionalização do mundo pode ser encontrada em Pierucci (2003).
} 
Esmiuçando o pensamento weberiano sobre esta especificidade, Domingues (2000: 222) explica que "a cidade configurara-se como espaço da liberdade e da autonomia precisamente porque floresceu em um momento extremamente peculiar no desenvolvimento histórico do Ocidente. Ela inserira-se em um contexto feudal, já em si contratual, estabelecendo-se um contrato de liberdade entre seus cidadãos - que formavam uma comunidade em todos os planos, inclusive em termos de significação cultural e sentido da ação: a defesa da liberdade compartilhada entre iguais. Ela escapara, com isso, paralelamente à sua inserção na tessitura contratual do mundo feudal, da lógica da dominação que o estrutura. Ela constituiu-se em momento absolutamente singular da história universal: estabelecera uma autonomia ante os estamentos dominantes no contexto societal global do feudalismo, tornando a dominação tradicional 'não legítima'. Ao mesmo tempo, desabrochara em um momento anterior ao desenvolvimento do Estado patrimonial, o qual levou à sua subordinação, à dominação racional-legal e, afinal, à perda daquela oportunidade histórica única de realização da liberdade. O credo coletivo da urbe, por seu turno, tecera uma comunhão entre os cidadãos sem que, por outro lado, se rompesse a efetiva esfera de autonomia de cada indivíduo, malgrado a profundidade já significativa da racionalização da conduta no que tange às questões econômicas. Mais ainda, a ação social não perdera seu sentido coletivo". Este era o "ar das cidades que torna as pessoas livres", ditado medieval lembrado por Weber e assim explicado em termos sociológicos.

Isto não é, contudo, um processo que se estabelece de maneira homogênea mesmo no interior daquele continente. O nascimento e expansão das cidades no norte da Europa não se deu tão cedo quanto no sul. Influenciaram nisto basicamente dois fatores: o modelo de urbanização já que em alguns lugares o campesinato representava um quarto, em outros metade do total de habitantes -, e os sistemas de produção - nos Países Baixos, por exemplo, a importação de cereais e a conseqüente diminuição da demanda por mão-de-obra no campo favoreceu uma mais alta taxa de urbanização (Bairoch, 1992). Esta condição repercutiu também no padrão de organização espacial e econômica em ambas as regiões. No Mediterrâneo se firmaram cidades comerciais, cuja abertura para o mar propiciava uma integração prioritária com outras regiões comerciais, num sistema complexo de trocas materiais e culturais. Já no norte, as cidades se firmaram a partir da relação com seu entorno, seja na estruturação de uma malha de aldeias e pequenas cidades, seja nas interfaces mais estreitas entre a produção agrícola e o 
artesanato (Braudel, 1979/1995) ${ }^{61}$. Neste segundo plano, segundo Duby (1973), a relação cidade-campo teria se estabelecido por meio da disseminação de "lugares mediadores", cuja posição, situada entre a vida citadina e a do village, pela atividade de seus notáveis e de seus homens de lei, de seus pequenos empresários, de seus comerciantes, viria a ser de importância capital até a consolidação da Revolução Industrial. No outro plano, típico, sobretudo, das regiões mediterrâneas, processos históricos impuseram ao campo formas diferentes de sociabilidade com influência urbana: os modos de produção, as relações políticas tinham ares citadinos, mas tratava-se, segundo suas palavras, de um muito antigo urbanismo. Nele, a posição privilegiada das cidades litorâneas contribuiu para a moldagem de uma relação com os campos através das instituições, da economia e das estruturas sociais de uma maneira mais hierarquizada e presidida pela possibilidade dos intercâmbios externos através do comércio.

\subsection{2 - O rural na "era industrial"}

Duby e Bairoch, ao menos, concordam que até o período da Revolução Industrial, apesar da antiga e crescente importância das cidades, durante séculos o motor da história esteve no meio rural e as cidades se desenvolveram como "parasitas tutelares" (Duby, 1973), expressão que, como sublinha Wanderley (2000), indica a dependência urbana em relação ao dinamismo econômico vindo do campo, e ao mesmo tempo um exercício pela cidade de funções de dominação sobre o meio rural. Com o tempo, o acúmulo de poderes acabou por se inverter e as cidades se tornaram donas de tudo e o campo verdadeiro servo e subordinado. A cidade passa a reunir os fatores favoráveis à inovação: demanda efetiva, possibilidade de contatos sociais que favorecem a circulação de informações, existência de pessoas e coisas dedicadas ao trabalho não agrícola.

Esta idéia é exatamente oposta ao argumento de Jane Jacobs (1984), para quem, desde as primeiras ocorrências do fenômeno urbano teria ficado claro que a evolução dos espaços rurais dependia das cidades, e não o contrário: as economias rurais seriam sempre tributárias das cidades porque o desenvolvimento é um processo de mudança intrínseca dentro de um contexto capaz de suportá-lo, no qual a diversificação e a possibilidade da produção e

\footnotetext{
${ }^{61}$ Para um excelente panorama sobre o lugar das cidades na evolução da história ocidental segundo uma perspectiva braudeliana, consultar o instigante texto de Maurice Aymard (1992).
} 
disseminação das inovações - ambos vistos como atributos específicos das cidades - são determinantes ${ }^{62}$.

Os argumentos de Jacobs são em parte muito pertinentes, mas as evidências históricas fazem a balança pender mais para o lado de Bairoch e Duby. Ela acerta na sua ênfase na diversificação, mas erra ao ver somente nas cidades o lugar possível para tanto. Mais interessante do que procurar em qual dos pólos se encontra a virtude imanente é compreender as múltiplas articulações possíveis entre eles e os resultados que estas interações geram. É possível identificar situações anteriores ao período de mais intensa urbanização em que o fluxo cidade-campo se estabeleceu de maneira a gerar impactos negativos para o segundo pólo - como é o caso emblemático da distribuição gratuita de cereais na Roma Antiga. E inversamente, é possível da mesma maneira divisar situações em que as condições de maior dinamismo das cidades repercutiram positivamente sobre os campos, por exemplo, através da metalurgia e de melhoramentos na ferramentaria agrícola, no aumento da produtividade, no comércio e introdução de novas variedades. Da mesma forma, Mazoyer \& Roudart (1997/2000) mostram claramente como a longa evolução desde a Revolução do Neolítico até a Revolução Industrial é pontuada por uma série nada desprezível de inovações. Os autores não chegam a afirmar que boa parte delas teve origem fora das cidades. Mas, considerando a frágil urbanização do mundo neste longo período, de um lado, e a riqueza e variedade destas inovações através da história, de outro, isto é facilmente presumível.

O que ninguém certamente nega é que, na longa passagem do período feudal para o capitalismo a cidade torna-se gradativamente o pólo dominante, e o faz rompendo pouco a pouco as limitações de que falava Bairoch. Com a Revolução Industrial e a urbanização, como foi dito, são solapadas as duas marcas de todo o período anterior, de resto abaladas já desde o século XI e mais intensamente desde o século XV: a "tirania da distância e da agricultura". Paradoxalmente, no entanto, as cidades não desempenharam um papel determinante no déclenchement da Revolução Industrial na Inglaterra, nem nos primeiros passos de sua transmissão espacial para o resto da Europa. Embora as cidades não estivessem ausentes do processo de criação de inovações técnicas importantes, um exame da localização das empresas dos setores motores das primeiras técnicas importantes mostra uma forte predominância, senão do meio puramente rural, ao menos das regiões de cidades muito

\footnotetext{
${ }^{62}$ Uma análise pormenorizada do tema na obra de Jane Jacobs foi muito bem feita por Karin Vecchiatti (2003).
} 
pequenas, no limite do rural. Isto se devia ao tipo de energia disponível - já que a primeira força motriz eram moinhos d'água e a segunda o carvão -, e a algumas características essenciais da economia - níveis salariais mais baixos no rural, custo mais baixo de terrenos e construções nestes espaços e a ausência de regulamentação (Bairoch, 1992). As fábricas surgem inicialmente no meio dos campos, reunindo a justaposição de trabalhadores individuais, e só depois vão para a cidade onde se introduz uma mais sofisticada divisão do trabalho.

Com o passar do tempo a variável técnica assume maior peso e, com isso, a situação inicial se inverte quase que por completo. As cidades vão gradativamente se tornar o lugar da monetarização das relações, da mobilidade social, da adequação entre oferta e demanda de mão-de-obra qualificada, da concentração da renda. Tanto é que, como mostra o Quadro 2, no século XVIII as cidades vão aparecer no imaginário da época associadas à riqueza e ao luxo. No século XIX à mobilidade e à formação das massas. E, mais tarde, no século XX, ainda à mobilidade, ao futuro, mas agora em situações de estranhamento típicas dos grandes e massificados ambientes urbanos. O rural, por outro lado, vai sendo mais e mais associado ao passado, ao rústico e ao idílico, à tradição, quando não ao irracional.

Analisando as transformações demográficas posteriores à Revolução Industrial, Bairoch nota que "algo acontece" no século XIX. No século XVIII a taxa de urbanização européia ficou estacionária, e os efeitos da industrialização, restritos ao Reino Unido. Até então se vivia mais no campo que na cidade, esta última crescendo principalmente graças à emigração de jovens. No século XIX, com a disseminação da Revolução Industrial pela Europa, a taxa de urbanização salta de $16 \%$ a 40\% no início do século XX. Este crescimento é interrompido nos anos 30 e no período da Segunda Grande Guerra para voltar a acelerar em seguida. Mas, agora, não mais no mesmo ritmo do século anterior. Se até a Revolução Industrial apenas uma ou duas cidades passavam da casa do um milhão de habitantes, na Primeira Grande Guerra oito cidades passavam dos dois milhões, e no Pós-guerra Nova York sozinha passa a casa dos dez milhões, mais que toda a população urbana da Europa e América do Norte há menos de quinhentos anos atrás, mais precisamente por volta de 1600. Não há dúvida, portanto, do quão intensa foi a urbanização do mundo ocidental ao longo dos últimos dois séculos, a ponto de importantes teóricos passarem a falar em Revolução Urbana ou em Civilização Urbana (Lefebvre, 1970/2002). 


\section{Quadro 2 \\ Literatura e vida rural}

Raymond Williams, analisando a evolução etimológica de denominação destes pólos na literatura, sublinha como, dos séculos XIII a XVI, vai se deslocar o sentido original de country, derivado de contra (against the observer), para o sentido moderno de espaço, firmando-se desde o século XVI como contraste de cidade. É nesse momento histórico que city, derivado de civitas, por sua vez originário em civis, passa a denominar uma grande cidade. Em Inglês antigo, isto era intercambiável com burh, por sua vez mais usado que urbs. A partir de então os contrastes são mais e mais invocados: countryman, countrypeople, mais tarde countryfield e countryside. Enquanto urbane guarda durante todo o período um significado marcado pela descrição difusa, rural e rustic, já presentes em descrições físicas desde o XV, vão adquirir implicações sociais também a partir de meados do século XVI. Mais tarde surgiria o termo metropolis, utilizado entre os séculos XVI e XVIII para denominar uma chief-town. Nos séculos XIX, e sobretudo no XX, o caráter social das distinções entre a cidade e o campo vão se acentuar mais e mais reforçando polaridades hoje tão presentes como a associação a uma e outra como lugares privilegiados da modernidade ou da tradição. Isto está presente em inúmeros romances que tratam da ascensão da burguesia e da urbanização, ou da mudança em padrões de comportamento, até o radicalismo que se apresenta como oposição entre racionalidade (da modernidade) e irracionalidade (do rural profundo), como no recente Desonra, do sul-africano J.M.Coetzee.

Na literatura brasileira, Os Sertões aparecem como essência da nação em oposição ao litoral já no clássico de Euclides da Cunha, na virada do XIX para o XX. Meio século depois (meio século atrás), mesmo no ápice da prosa de Guimarães Rosa, o Grande Sertão só é acessível pelas veredas que o separam do mundo urbano em franca expansão, envolvendo e desencantando o rural. Desde então, no Brasil em particular e na América Latina em geral, a ficção urbana vai ser mais e mais predominante, e o lugar do rústico, do rural, vai ser reservado às terras e histórias perdidas do Romance d'A Pedra do Reino de Ariano Suassuna. Ou ao passadismo de Juan Rulfo em Chão em Chamas e Pedro Páramo, onde mal é possível divisar os personagens vivos dos mortos em ambientes quase surreais. Um dos últimos exemplos de grandes romances que se passam no sertão mostra como o passado se confronta ou se dilui no presente, na forma das heranças agrárias, coloniais, escravistas. Em Sargento Getúlio, de João Ubaldo Ribeiro, o personagem como que a representar todo um universo, uma forma histórica da qual é agente típico, recebe ordens para "desaparecer do mapa", e retruca: "quem pode sumir é os outros, como é que eu posso sumir se eu sou eu ?". O mesmo personagem chega ao fim do livro olhando a capital do Estado do outro lado do rio, após sua longa peregrinação: a cidade, lugar associado à mudança e à liberdade, estava ali, tão perto e tão inacessível.

Elaboração do autor com base nas obras citadas. 
Ao mesmo tempo, não há, contudo, indícios que apontem para uma intensificação ainda maior ou sequer no mesmo ritmo nos tempos atuais. Isto é, não se trata de questionar a dominação urbana do mundo contemporâneo, mas sim de qualificá-la, para então avaliar seu significado em relação aos momentos anteriores e, particularmente, para a permanência ou não do estatuto empírico e teórico do pólo dominado, o rural. A conformação das tendências futuras exige uma maior decantação das tendências demográficas recentes, cujos sentidos atuais são bastante multifacetados, comportando distintos padrões de urbanização e de relação entre as cidades e o espaço rural que lhes envolve. Por isso, antes de passar ao exame do novo estatuto da ruralidade no mundo contemporâneo, cabe dedicar algumas linhas à especificidade latinoamericana.

\subsection{3 - A peculiaridade latinoamericana}

No caso específico do chamado "Terceiro Mundo", seria um erro analisá-lo como mera extensão ou cópia imperfeita do que ocorre nos países do capitalismo avançado. Na América Latina, particularmente, há livros clássicos que tratam diretamente da peculiaridade latinoamericana: José Luis Romero (1976/2004) e, antes dele, Sérgio Buarque de Holanda (1936/1995), já haviam mostrado como as cidades se constituíram como porta de entrada e aliada da Colonização.

Numa conhecida passagem de Raizes do Brasil, há uma tipologia das cidades latinoamericanas contrapondo o racionalismo das cidades hispânicas, fundadas sobre um conjunto de prescrições que aparecem no desenho planejado, no traçado reto de suas ruas e vias, e o barroquismo das cidades luso-brasileiras. Romero, sob direta influência da metodologia weberiana dos tipos ideais, classifica cinco tipos de cidades latino-americanas, tipos que se sucedem e cuja diferenciação é dada pela classe ou grupo social dominante. A sequência histórica tem início com o ciclo das fundações que trouxe a constituição das cidades com suas funções pré-estabelecidas pela Coroa, com seus grupos urbanos originários e sua mentalidade fundadora, a mentalidade expansionista européia. Nas belas palavras de Romero (1979/2004: 96-97), “...posicionados em frente ao lugar escolhido, com a mão apertada na empunhadura da espada, o olhar fixo na cruz e os pensamentos direcionados para as riquezas que a aventura lhes proporcionaria, os homens do grupo fundador da cidade que já tinha nome, mas da qual nada existia sobre o solo, deveriam experimentar a sensação de quem espera o 
prodígio da criação surgida do nada. Eram europeus em um continente desconhecido, e a criação estava prefigurada em suas mentes. Porque esta façanha não era, na verdade, senão um passo a mais nessa ambiciosa aventura européia de expandir-se, iniciada quatro séculos antes. A terra que agora ocupavam - uma terra real com rios e planícies, lagos e vulcões deveria ser uma extensão da terra que deixaram no dia em que embarcaram em seus navios. (...) A mentalidade fundadora foi a da expansão européia conduzida por essa certeza absoluta e inquestionável da posse da verdade. A verdade cristã não significava somente uma fé religiosa: era, a rigor, a expressão radical de um mundo cultural. E quando o conquistador trabalhava em nome dessa cultura, não só afirmava o sistema de interesses que ela representava como também o conjunto de meios instrumentais e de técnicas que a cultura burguesa havia acrescentado à velha tradição feudo-cristã. (...) Os grupos fundadores expressavam essa interpenetração feudo-burguesa que na península ia ajustando as relações entre as classes e também entre os fins e os meios. (...) Graças àquela certeza, a mentalidade expansionista européia havia concebido o projeto de instrumentalizar o mundo não cristão de acordo com seus próprios interesses, e afirmou-se nessa convicção cada vez mais, à medida que os meios iam aumentando suas possibilidades: à maior superioridade técnica correspondeu maior certeza da validade de seus fins".

Esta passagem traz, não uma, mas várias significações importantes. Entre muitas, ela fala da forma de apropriação do espaço e dos recursos naturais, do tipo de relação entre colonizadores e colonizados, da extensão que o Novo Mundo representava em relação ao imaginário europeu da época. Fala, em suma, do sentido da Colonização. Da Colonização como instituição, do que ela representava para as formas de interpretação da relação com o novo espaço, seus homens e suas coisas. Combinavam-se assim atitudes senhoriais e atitudes burguesas, por razões que remontam às necessidades de colaboração entre estes dois segmentos da sociedade européia do período da Colonização.

Os cinco tipos que se sucedem desde então são, sempre segundo a tipologia de Romero, as cidades fidalgas, as cidades "criollas", as cidades patrícias, as cidades burguesas e as cidades massificadas, finalmente, no século XX. Nelas, a cidade que se desenvolve em razão do comércio vai gradativamente gerando as elites governantes da época dos processos de independência e, posteriormente, os grupos integrados e dependentes do capital internacional do período de mais intensa industrialização. 
No Brasil as cidades de início não alcançaram a mesma importância que nos demais países latino-americanos. É somente nos meados do século XVIII que há um maior fortalecimento dos grupos urbanos e das funções intermediárias das cidades. Até então a sociedade agrária havia imposto sua imagem de realidade. Novamente nas palavras de Romero (1979/2004), “...foram os senhores da terra que esboçaram o primeiro perfil do Brasil colonial, ao passo que as populações urbanas - artesãos e pequenos funcionários, clérigos e pequenos comerciantes - foram suplantadas. Até o século XIX, só algumas cidades - Salvador da Bahia e, sobretudo, a Recife holandesa - insinuaram a sua capacidade de influir na poderosa aristocracia fundiária, que amava a vida rural e residia em meio a suas propriedades".

Isto significava um sentido totalmente diferente para a relação entre as cidades e seu entorno. Enquanto a Espanha havia imaginado seu império colonial como uma rede de cidades, o domínio português se limitava à exploração econômica. Na raiz desta diferença, segundo Romero, estava a experiência de choque com os muçulmanos, que levou durante bom tempo à ocupação de parte da Península Ibérica, o que culturalmente se traduzia num medo terrível da possibilidade da mestiçagem e da aculturação. Assim, a cidade "racional" da América hispânica era militarizada e disciplinada para evitar tais riscos, enquanto na América lusobrasileira as cidades se fundaram por princípios mais pragmáticos. Esta prevalência do rural como centro ideológico do mundo luso-brasileiro permaneceu até o momento em que as mudanças acentuadas do capitalismo industrial instituem, sobretudo a partir dos fins do século XIX, uma sociedade crescentemente urbanizada. É assim que a "rede de latifúndios" vai sendo substituída por uma "rede de cidades", de maneira similar ao que acontecera na América hispânica.

O fundamental a destacar é que, tanto em Romero como em Buarque de Holanda, as cidades e o processo de urbanização, suas relações com o mundo rural, são muito mais que realidades físicas, são materializações de formas de vida e de mentalidade. Nos dois autores este processo de integração leva a uma espécie de triunfo do mundo urbano, mas numa síntese muito peculiar. Em Buarque de Holanda, a urbanização tragaria pouco a pouco o "homem cordial", criação do mundo rural, agregado, isolado, dependente, incorporando-o como uma 
espécie de portador do passado agrário. Em Romero, embora haja a constante presença dos pólos rural e urbano, é neste último que reside o foco dinâmico da história.

Mas apesar de tudo isto, também nos dois autores há uma constante interpenetração entre os dois pólos: na forma das heranças ibéricas que irão se traduzir no viés patrimonial e patriarcalista das instituições, segundo o autor brasileiro, na forma de ideologias contrapostas e que interagem dialeticamente, embora sempre presididas pelo pólo urbano, segundo o autor $\operatorname{argentino~}^{63}$. Já para outro autor brasileiro clássico, Gilberto Freyre, o peso das polaridades seria simplesmente inverso: as raízes escravistas originárias da oposição entre Casa Grande e Senzala, teriam se estendido para o mundo urbano e se materializado na antítese dos Sobrados e Mocambos, segundo livro de sua trilogia, e tenderiam mesmo a se perpetuar, em Jazigos e Covas Rasas, título planejado para o terceiro livro, que nunca foi publicado ${ }^{64}$. Não é de outra coisa que fala Raymundo Faoro em Os Donos do Poder ou, no caso das estruturas econômicas, as principais obras de Celso Furtado e de Caio Prado Jr. ${ }^{65}$.

Esta diluição e persistência do rural no urbano é uma primeira característica marcante da América Latina e do Brasil em particular. Por certo também na Europa e EUA, mas ali as rupturas introduzidas em passagens históricas fundadoras da modernidade nestas nações em alguma medida "resolveu" esta herança, seja através do protagonismo direto que as populações camponesas tiveram em tais eventos, do qual a Revolução Francesa talvez seja o maior exemplo, seja ainda pela diminuição da hierarquia social que pesa sobre os habitantes dos dois espaços, o urbano e o rural, ao longo de toda a história recente daqueles países. Trata-se, na América Latina, de uma continuidade com viés marcadamente negativo nas formas de representação social, como herança agrária, patriarcal, escravista, ou como lugar por excelência da dominação tradicional, da pobreza e da subordinação.

\footnotetext{
${ }^{63}$ Um analista da obra de Romero, Gorelik, citado na apresentação de seu livro, chega a qualificar a postura do autor argentino como uma espécie de 'otimismo urbano': “...o campo seria, assim, para o Romero que lê Sarmiento, a barbárie da necessidade e da liberdade, que como possibilidade só pode se aninhar na cidade".

${ }^{64}$ Em seu lugar, e numa substituição sintomática, Freyre publicou Ordem e progresso. Ao que parece Freyre não abandonou a intenção de publicar Jazigos e covas rasas, mas este projeto foi interrompido com sua morte.

${ }^{65}$ Num Colóquio sobre "Villes et Campagnes" realizado nos anos cinqüenta na França, Fernand Braudel chamava a atenção dos historiadores e geógrafos franceses sobre a então recente produção brasileira e sua habilidade em mostrar as permanências do mundo agrário na urbanização crescente. Não é mero acaso o fato de ser este um traço fundamental nas três obras que Antonio Candido considerou serem as leituras indispensáveis sobre a formação do Brasil: Casa Grande e Senzala, Raizes do Brasil, e Formação do Brasil Contemporâneo.
} 
Outra característica é a velocidade e o formato em que se deu o fenômeno da urbanização. A partir das décadas de 20 e 30 do Século XX, acontece uma progressão sem precedentes na história. No chamado "Terceiro Mundo", em 1930, cento e cinqüenta milhões de pessoas já viviam nas cidades. Mas pouco mais de meio século depois este número havia sido multiplicado por dez, e chegado próximo de um e meio bilhão de pessoas em áreas urbanas ${ }^{66}$. Salvo exceções, este aumento da população - impulsionado pela introdução de técnicas médicas e sanitárias ocidentais, pelo descarte da mão-de-obra nos campos, pela extensão rápida da educação no meio rural criando um fosso entre duas gerações, e por um intenso êxodo rural motivado pela busca por salários mais altos nas cidades, (Bairoch, 1992) - se fez com frágil desenvolvimento econômico, com uma débil industrialização e, mais grave, sem proporcional aumento da produtividade agrícola, levando a uma hipertrofia urbana, a uma superurbanização.

A terceira característica marcante da urbanização do "Terceiro Mundo", por fim, é a concentração nas cidades muito grandes. Em 1930, quase um terço da população já estava em cidades de quinhentos mil habitantes, enquanto na Europa, continente de urbanização muito mais antiga, este percentual era de $20 \%$. Neste mesmo momento seis cidades já tinham mais de um milhão de habitantes, número que salta para vinte em 1950 e para cento e trinta em 1980. E em 1990, oito cidades já estavam com sete a dez milhões de habitantes. Por tudo isso não é exagero chamar este processo de "inflação urbana do Terceiro Mundo". E como tal, suas conseqüências principais não são das mais virtuosas: criou-se uma situação de déficit alimentar, quando às vésperas da Segunda Grande Guerra havia excedente, criou-se um déficit de empregos urbanos, e ocorreu uma hipertrofia do setor terciário (Bairoch, 1992).

Não é de estranhar, portanto, a diferença entre o rural e o urbano nos países do capitalismo avançado e nos países da América Latina, Ásia e África. O fenômeno urbano aqui se constituiu sobre estruturas sociais e instituições outras porque os agentes e os processos históricos se compuseram de maneira diferente. A herança colonial e escravista, associada à hipertrofia urbana e à vertigem resultante da velocidade com que ela se deu é, a um só tempo, resultado e causa de um estilo de urbanização que se fez sem a criação de classes e lugares mediadores, a exemplo daquilo que os villages e seus respectivos atores representaram na

\footnotetext{
${ }^{66}$ Para se ter uma idéia da proporção e magnitude destes números, entre 1945 e 1970 o crescimento foi de 4,5 $\%$ a / a , enquanto na Europa entre 1880/1905 este percentual foi de 2\% a/a . Detalhe: com a China puxando a média para baixo (Bairoch, 1992).
} 
Europa Ocidental. Por aqui, as técnicas agrícolas, que tiveram nas cidades uma importante fonte de irradiação, foram importadas dos países do capitalismo avançado. O padrão de urbanização, apoiado em cidades muito grandes, exigiu grandes volumes de importações, com impactos para o balanço econômico. A monetarização da vida social signifícou endividamento e não liberação dos laços servis. E a complexidade das técnicas e a integração econômica mundial tornaram as trocas entre países e regiões mais importantes que as trocas entre cidade e campo. Em síntese, na América Latina e no restante do chamado Terceiro Mundo, diferente da Europa, a urbanização tal como se deu foi mais um fator de subdesenvolvimento, e não propriamente um trunfo ao desenvolvimento (Bairoch, 1992). Além disso, constituiu-se uma verdadeira ideologia urbana que, em última análise, traduz-se como um "não lugar' do rural na modernidade, interditando assim a possibilidade de que seja legítimo preconizar que estes amplos espaços possam ser objeto de investimentos e de expectativas futuras.

As tipologias de Romero e Buarque de Holanda são excelentes para análises de longo prazo, como a aqui empreendida, pois sinalizam o sentido mais geral da evolução, os caracteres mais fortes que permanecem após sucessivas etapas. Mas trazem consigo uma dificuldade, que é não permitir uma leitura da heterogeneidade interna destas grandes unidades como países ou continentes num dado momento histórico. Na Europa já há uma tradição estabelecida em explorar os contrastes espaciais das relações entre cidades e campos, como foi possível observar através das obras de Braudel, Duby, Bairoch. E nos anos mais recentes vários estudos acadêmicos ou patrocinados pela União Européia ou órgãos de governo têm elaborado interessantes tipologias e estudos comparativos, alguns dos quais serão abordados no próximo capítulo. Na América Latina, ou ao menos no Brasil, simplesmente não há trabalhos consagrados que explorem as relações entre o rural e o urbano tendo por objeto o mapeamento e classificação de um número razoável de realidades. Só muito recentemente, nos últimos dez anos, têm surgido programas de pesquisa explorando este tema sob diferentes enfoques ${ }^{67}$.

Tanto os achados destes programas de pesquisa como a ascensão mesmo dos interesses pelas relações entre o rural e o urbano são resultado de um momento particular da história destes

\footnotetext{
${ }^{67}$ Cf. Projeto CUT-Contag (1998), IBGE/IPEA/Nesur-Unicamp (1999), Abramovay (2002).
} 
espaços, cujo significado pode ser o fim ou no mínimo um arrefecimento da urbanização intensa experimentada até então.

\section{2 - Uma nova etapa?}

Nos anos 70 do século XX, pela primeira vez desde a Revolução Industrial a taxa de urbanização dos países do capitalismo avançado fica estagnada. Passa-se a falar até em urbanização dos campos, o que poderia significar tanto uma contradição em termos como o sinal de dissolução de uma oposição. Os processos sociais que levam a esta diminuição da distância entre os dois espaços estão na raiz de uma interrogação formulada por Paul Bairoch: trata-se de uma nova etapa ? Isto é, fenômenos antes concernentes à urbanização atingem um outro universo sem, no entanto, fagocitá-lo ? Ou este processo sinaliza uma homogeneização entre os dois pólos forte o suficiente para apagar suas distinções substantivas ?

Estas foram questões que permearam os debates que se estabeleceram, a rigor já desde os anos 50, mas mais aprofundadamente desde os 70, na Europa. Uma boa síntese pode ser encontrada num emblemático número da revista Études Rurales, organizado por Georges Duby, e que trazia por título L'urbanisation des campagnes. Reunindo textos de alguns dos mais influentes pesquisadores franceses da época, a publicação trazia vários artigos que atestavam e analisavam as características e implicações deste fenômeno de diluição das assimetrias entre o urbano e o rural na Europa, e na França em particular. O texto de Julliard (1973), por exemplo, já apresentava uma tipologia mais complexa, com uma abertura para diferentes composições entre cidades e campos: cidades rentistas do solo, amparadas em uma relação de parasitagem com o meio rural; cidades que cresceram sem laços orgânicos com o meio rural, envolvendo-o, mas esterelizando-o em vez de fecundá-lo; cidades que associaram sem ruptura o campo a seu próprio desenvolvimento. O que é quase consensual desde então é que as transformações econômicas, o processo de modernização da produção e a crescente integração dos mercados levaram ao fim de um tipo específico de ruralidade, aquela que já foi chamada por Mendras de "sociedades camponesas".

Três características importantes desempenharam papel-chave nesta nova situação. Primeiro, o compromisso institucional que se criou, historicamente, em torno da garantia da paridade econômica e social entre os agricultores e os demais setores e que é muito bem retratada em 
Jollivet \& Gervais (1976). Isto criou condições para que se aproximassem as condições de vida em ambos os espaços, contribuindo tanto para a vitalidade econômica do meio rural como para regular o impulso ao êxodo, que até então era tão forte. Segundo, e em parte motivado pelo elemento anterior, o padrão de crescimento demográfico que passa a vigorar não aponta mais para o esvaziamento dos campos, mas até para a situação inversa, para a atração populacional destes espaços, inicialmente através do dinamismo gerado pela equalização das rendas, num segundo momento, com o avanço da infra-estrutura e das possibilidades de comunicação, com novos habitantes, sobretudo profissionais liberais e idosos em busca de amenidades e lazer. Terceiro, a descentralização econômica e política que propiciou tanto o surgimento de novas oportunidades de trabalho como também a viabilização de equipamentos sociais adequados a uma população com exigência crescente, estes dois últimos aspectos mais destacados por Kayser (1972, 1990).

São evidências empíricas que, sem dúvida, permitiriam responder positivamente à pergunta de Bairoch: os tempos atuais representam, por certo, um novo momento, uma nova etapa. Nesta condição, muda a estrutura e a dinâmica das relações entre os campos e as cidades. A primazia marcante das atividades primárias - agricultura, pecuária, mineração, silvicultura cede espaço a uma maior diversificação, com uma crescente heterogeneização das economias rurais, onde se destaca o crescimento cada vez maior do setor de serviços. Com isso, mudam as vantagens comparativas do rural nas possibilidades de captação das rendas urbanas. A localização, fertilidade, e o preço da terra passam a dividir importância com a acessibilidade, a paisagem. Da mesma forma, a composição do perfil populacional e as tendências demográficas típicas do período anterior são substituídas por um forte arrefecimento, ou mesmo uma inversão nos fluxos demográficos. São outros agentes, novas variáveis introduzidas ou tornadas mais relevantes, novos interesses, uma nova estrutura de oposições e identidades que sustentam a especificidade desta nova configuração da relação rural-urbano. E para completar, muda também o ambiente institucional que orienta a regulação das formas de uso social dos recursos naturais. Se é verdade que desde a Antiguidade já há leis e sanções que dão os parâmetros para as formas de apropriação da natureza, o que ocorre a partir de então é uma mudança também neste domínio do mundo social: o acesso à terra, a gestão de bacias hidrográficas, a conservação de florestas e rios, e a valorização da paisagem e da biodiversidade passam a ser novos aspectos incorporados aos anteriores. O que é novo, além da extensão de domínios regulados cada vez mais por instituições formais, é a forma como 
isso se dá, menos orientada por decisões do tipo comando e controle, e mais por compromissos institucionais. Em outros termos, muda também o estatuto da dominação ${ }^{68}$.

Mas e pelo ângulo teórico, qual o estatuto desta nova situação ? Duas são as perguntas, na verdade. Primeiro, é preciso esclarecer se a inauguração deste novo momento, desta passagem, localizada aproximadamente no último quarto do século $\mathrm{XX}$, trouxe consigo um fim do rural, se com o "fim das sociedades camponesas" de que falava Jollivet (talvez fosse melhor falar em "sociedades agrárias"), acaba também a relevância histórica e explicativa da ruralidade. Segundo, caso a resposta à questão anterior seja negativa e ainda há conteúdo compreensivo na distinção entre o rural e o urbano, cabe interrogar então qual é seu sentido.

Em dois artigos recentes Veiga $(2004,2005)$ vê nas idéias de Henri Lefebvre e de Bernard Kayser as melhores expressões para as duas respostas extremas à primeira destas perguntas. Por isso vale à pena vê-las um pouco mais de perto.

Lefebvre dedicou parte expressiva de sua obra à produção social do espaço, inicialmente com uma ênfase em estudos rurais, que se desloca posteriormente para os fenômenos relativos à urbanização. No seu influente livro A revolução urbana, de 1970, ele a designa como um amplo conjunto de transformações que fariam as sociedades passar do período em que predominaram questões típicas da sociedade industrial - como emprego, crescimento e industrialização - para outras, nas quais a problemática da sociedade urbana ganharia relevo e preeminência. Nesta sociedade urbana, típica do período pós-industrial, a urbanização completa "hoje virtual, amanhã real" envolveria e dominaria o conjunto de esferas do mundo existente e o destino dos espaços rurais seria, portanto, a diluição de seus caracteres substantivos neste movimento envolvente da sociedade urbana ${ }^{69}$.

Apenas quatro anos mais tarde o mesmo autor publicou outro influente livro, The production of space, onde a hipótese da urbanização completa não tem mais o mesmo caráter de eixo argumentativo. Este possível recuo, se não de conteúdo, ao menos de ênfase, pode ser resultado tanto de uma melhor ponderação de Lefebvre - que admitia já no livro de 1970 que tal idéia deveria ser considerada como hipótese, a fim de não se confundir o categórico com o

\footnotetext{
68 Vários trabalhos abordam isolada ou combinadamente estas mudanças. Ver, entre outros, Kayser (1990, 1993), Veiga (1998), Wanderley (2000), Abramovay (2003).

${ }^{69}$ Cf. Lefebvre (1970/2002).
} 
problemático, o especulativo com o empiricamente demonstrável -, ou pode ter sido também resultado da constatação, sublinhada por autores igualmente importantes da época, de sinais de vitalidade ainda emitidos pelo meio rural.

Esta ambigüidade nos desdobramentos da obra de Lefebvre não quer dizer que ela tenha sido totalmente deixada de lado, nem por seu formulador, nem muito menos por seguidores de suas idéias em vários ramos do conhecimento ${ }^{70}$. Mas o fato é que não há, neste autor e nem na linhagem que ele inaugura, uma demonstração do esvaziamento do conteúdo social e explicativo do rural. Tal afirmação vem sempre embasada em uma tautologia: a urbanização generalizada tem como devir a sociedade urbana, à dinâmica da qual nada escapa.

No extremo oposto, Bernard Kayser lançou suas idéias sobre este problema em 1972, mas elas foram melhor sistematizadas no livro La renaissance rurale, de 1990. Embora apoiandose sobretudo em dados demográficos, Kayser, diferente de Lefebvre, reportou-se a situações muito concretas que estariam ocorrendo em diferentes espaços dos EUA e do Velho Continente e que apontavam para uma revitalização de áreas antes condenadas à estagnação e ao esvaziamento. Um renascimento que teria em sua base os efeitos do "enriquecimento do conjunto da sociedade", passível de percepção através de fenômenos como a atração populacional, o crescimento de atividades não-agrícolas, iniciativas de desenvolvimento local e uma mudança no perfil demográfico. Com isso, em vez de desaparecer, os campos pareciam renascer, agora integrados complementarmente às cidades: os campos, como lugar da liberdade e da beleza, as cidades, como centros de lazer e de trabalho (Hervieu \& Viard, 1996/2001).

Ao discutir os argumentos destes dois autores, Veiga $(2004,2005)$ oferece uma terceira hipótese: as mudanças por que vêm passando o rural contemporâneo não dão lugar nem ao fim do rural, como em Lefebvre, nem a um renascimento, como em Kayser, mas diferente de ambos, enseja a emergência de uma nova ruralidade.

Para contestar os argumentos de Lefebvre, Veiga procede inicialmente a um exercício de demonstração da permanência dos traços distintivos da ruralidade no mundo contemporâneo,

\footnotetext{
${ }^{70}$ No Brasil, ver por exemplo os trabalhos de Monte-Mor (2003). Uma apresentação mais circunstanciada e pormenorizada das idéias de Lefebvre pode ser encontrada também em Martins (1996).
} 
concentrando-se, num primeiro instante, no grau de artificialização dos ecossistemas como critério fundamental de distinção do rural e do urbano. Ali, pode-se constatar que $50 \%$ da área do globo terrestre, excetuando a Antártica, permanecem "praticamente inalterados", contra 24\% "parcialmente alterados", e 22\% "fortemente artificializados". Nesta última categoria, que inclui as áreas com agropecuária intensiva e assentamentos humanos nos quais foi removida a vegetação primária e onde há desertificação ou outras formas de degradação permanente, apenas a Europa apresenta um percentual de área mais expressivo, de 65\%. O segundo continente mais artificializado é a Ásia, onde este número cai para $29 \%$. E na América do Sul esta fração é de meros $12 \%$. A partir daí Veiga concentra sua análise no continente Europeu, por considerar que o debate sobre a permanência ou desaparecimento da ruralidade deve ter por objeto situações onde a urbanização foi mais longe. Além disso, seria preciso valer-se de critérios não estritamente ecológicos, como aquele expresso no grau de artificialização dos ecossistemas. Portanto, utilizando então dados da OCDE, produzidos a partir de um tableau de indicadores demográficos, ambientais e sócio-econômicos, Veiga mostra que nada menos do que $28 \%$ da população européia vive em regiões predominantemente rurais, enquanto $40 \%$ habitam as regiões predominantemente urbanas, e $32 \%$ as regiões relativamente rurais. Estes dados seriam suficientes para, no mínimo, mostrar que não se chegou ao grau completo de urbanização de que fala Lefebvre, mas não seriam suficientes para anular sua hipótese. Os partidários de suas idéias poderiam argumentar que tais sociedades caminham para tal padrão, o que já seria possível vislumbrar a partir dos dados de países como Reino Unido, Bélgica ou Holanda, onde as regiões predominantemente rurais praticamente deixaram de existir. No entanto, a análise tendencial dos mesmos dados mostra uma situação diferente. Quem mais atrai população, aumentando assim seu peso relativo, é a categoria intermediária, formada pelos espaços "significativamente rurais". Tanto o "rural profundo" como as regiões metropolitanas ou mais densamente urbanizadas apresentam declínio. Não há, portanto, evidências empíricas que confirmem o movimento apontado por Lefebvre e sinalizem um fim do rural.

Quanto ao argumento de Kayser, o estudo de Veiga apresenta uma concordância inicial no que diz respeito à permanência do rural, mas diverge quando se trata de qualificar seu estatuto nos tempos atuais. Tendo por base um significativo rol de pesquisas sobre o rural europeu, Veiga mostra como tal situação não resulta de um impulso que faz voltar os fundamentos da ruralidade pretérita, ainda que traços dela persistam e coexistam no novo 
momento. Trata-se, sim, de uma nova ruralidade, que se apresenta metamorfoseada. A novidade está no fato de que "nunca houve sociedades tão opulentas quanto as que hoje tanto estão valorizando sua relação com a natureza", e isto não somente no terreno das preocupações com os problemas ambientais, como as ameaças à biodiversidade ou o aquecimento global, mas também no que diz respeito à liberdade conquistada com a maior mobilidade e com o enriquecimento da sociedade e o que isto permite em termos de aproveitamento das amenidades naturais, seja através da constituição de novas residências em áreas rurais, seja através das atividades turísticas. Mesmo as atividades produtivas que não se apóiam diretamente em novas formas uso social dos recursos naturais guardam com eles estreita correspondências: em inúmeros casos é possível constatar uma descentralização da atividade industrial, motivada tanto pela capacidade de certas áreas rurais em atrair potenciais empreendedores devido às características ambientais de residência, como pelo dinamismo empreendedor voltado para mercados emergentes e que explora as vantagens competitivas derivadas das melhores condições de vida e de trabalho destas mesmas áreas (North \& Smallborne apud Veiga 2004).

Os dados da OCDE (1996), utilizados por Veiga, mostram mesmo que, nas regiões predominantemente rurais é raro encontrar algum país onde o percentual de ocupados na agricultura supere a casa dos 30\%, o que ocorre somente na Islândia e na Grécia. Na maioria, é o setor de serviços que responde pela maior fatia, chegando a $88 \%$ na República Tcheca e, na maior parte dos casos, situando-se acima do percentual de 50\%. Em suma, a vitalidade do rural não se resume mais aos campos, como lugar de realização de atividades primárias, mas a uma trama complexa envolvendo os campos e suas cidades, com destaque para uma integração intersetorial da economia, e para uma emergência da variável ambiental como elemento chave. Tudo isso levou Veiga (2005) a afirmar, em consonância com outros estudos como Wanderley (2000) e Abramovay (2003), que trata-se efetivamente de uma nova ruralidade. E que, segundo o autor, se expressa em três vetores: os desdobramentos paisagísticos dos esforços de conservação da biodiversidade, o aproveitamento econômico das decorrentes amenidades naturais através de um leque de atividades que costumam ser tratadas no âmbito do turismo, e a crescente necessidade de utilização de fontes renováveis de energia disponíveis nestes espaços rurais. 


\section{Síntese do Capítulo 2}

A longa evolução da relação entre campo e cidade mostra claramente a permanência do fenômeno rural no mundo contemporâneo, mesmo no momento e nos países em que a urbanização foi mais intensa. A oposição campo-cidade se desloca para a contradição ruralurbano. Enquanto a primeira diz respeito ao contraste entre espaços, sendo os campos o lugar de realização de atividades predominantemente primárias, destacadamente a agricultura, na segunda o estatuto fundante da distinção desloca-se para o grau de artificialização destes espaços e seus impactos para os modos de vida, exigindo assim uma abordagem capaz de combinar critérios ecológicos com outros de caráter social e econômico. O rural mostra-se não mais uma categoria passível de ser apreendida em termos setoriais, e sim territoriais.

Três, portanto, são as dimensões definidoras fundamentais da ruralidade (Abramovay, 2003): a proximidade com a natureza, a ligação com as cidades, e as relações interpessoais derivadas da baixa densidade populacional e do tamanho reduzido de suas populações. Na nova etapa, muda o conteúdo social e a qualidade da articulação entre elas. No que diz respeito à proximidade com a natureza, os recursos naturais, antes voltados para a produção de bens primários, são agora objeto de novas formas de uso social, com destaque para a conservação da biodiversidade, o aproveitamento do potencial paisagístico disto derivado, e a busca de fontes renováveis de energia. Quanto à relação com as cidades, os espaços rurais deixam de ser meros exportadores de bens primários para dar lugar a uma maior diversificação e integração intersetorial de suas economias, com isso arrefecendo, e em alguns casos mesmo invertendo, o sentido demográfico e de transferência de rendas que vigorava no momento anterior. As relações interpessoais, por fim, deixam de apoiar-se numa relativa homogeneidade e isolamento para dar lugar a um processo crescente de individuação e de heterogeneização, compatível com a maior mobilidade física, com o novo perfil populacional e com a crescente integração entre mercados antes mais claramente autônomos no rural e no urbano, mercados de bens e serviços, mas também o mercado de trabalho e o mercado de bens simbólicos. 


\section{Capítulo 3 - Ruralidade nos países do capitalismo avançado}

Constatar que no momento atual a humanidade experimenta a emergência de uma nova ruralidade e qualificá-la, como foi feito no Capítulo 2, é certamente importante, porque marca as diferenças entre caracteres atuais destes espaços e aqueles outros que foram mais importantes nas etapas históricas anteriores. Serve para mostrar a obsolescência de certos traços, a ascensão de outros, e o que isto traz de implicações para grupos ou dimensões específicas dos espaços rurais: que agentes perdem e quais ganham força, que processos econômicos adquirem caráter estruturante e quais se tornam subsidiários, qual a significação em torno das formas de apropriação e uso dos recursos naturais, como tudo isso se relaciona a outras esferas do mundo social, destacadamente com os espaços urbanos. Mas tudo isto diz muito pouco quando se trata de responder porque diferentes territórios se inserem de maneira desigual nestas grandes tendências. Por que certos territórios, mesmo gozando de uma dotação inicial de recursos similar a outros adquirem trajetórias tão díspares, como é o caso de certas ilhas mais remotas do Reino Unido ? Ou, em direção um pouco diferente, por que certas regiões continuam a apresentar carências graves em quase todos os indicadores sociais, ambientais e econômicos mesmo após pesados e duradouros investimentos governamentais, como é o caso típico do Mezzogiorno italiano ?

A melhor maneira de enfrentar interrogações de tamanha amplitude e complexidade talvez seja começar admitindo que não existe uma reposta única para elas. O que há, sim, são lições, aprendidas com um importante rol de pesquisas e estudos levados adiante nos últimos trinta anos. Sistematizar estes achados e delinear as conseqüências que eles trazem para o conhecimento científico sobre o desenvolvimento rural é o principal objetivo deste capítulo ${ }^{71}$. Para fins de exposição, esta pergunta principal é aqui desmembrada em três, às quais correspondem cada uma das seções deste capítulo. A primeira busca brevemente recuperar as principais definições sobre o que é o espaço rural nos países do capitalismo avançado. Isto será útil não somente para delimitar de que unidade empírica se está falando, mas também, e principalmente, para pôr em relevo a base material que dá substância para estas tentativas de conceituação. A segunda seção mapeia algumas das tendências recentes destes espaços com o

\footnotetext{
${ }^{71}$ Partes deste capítulo foram apresentadas originalmente na forma de artigo no Congresso da Sociedade Brasileira de Sociologia e Economia Rural (Sober), do ano de 2004. Cf. Favareto (2004-b).
} 
intuito de mostrar, de um lado, sua consonância com os caracteres relativos à longa evolução do rural, já destacados no capítulo anterior, e, de outro, a heterogeneidade que marca a extensão e profundidade destas tendências e dos conflitos que as cercam. A terceira seção, a mais longa, expõe os achados dos principais programas de pesquisa, dedicados tanto às dinâmicas sócio-econômicas do rural europeu e norte-americano contemporâneos como às iniciativas públicas voltadas à sua dinamização.

\section{1 - As definições sobre o que é o rural}

Importantes trabalhos publicados nos últimos anos já trataram do problema que envolve as definições sobre o que pode ser considerado rural na Europa e EUA (Wanderley, 2000; Abramovay, 2003; Veiga, 2004). Por isso, o intuito aqui não é uma reconstituição exaustiva das formas de classificação disponíveis, mas, apenas, sublinhar os critérios que vêm sendo mais utilizados nos tempos atuais e, junto disso, delinear as dimensões atuais do rural contemporâneo nestes países onde a urbanização foi mais longe.

Na Europa são utilizadas definições diferentes em cada país, muitas vezes combinando vários critérios. O mais comum deles é a demografia, e em dois sentidos: o tamanho da população, e a densidade populacional. Outro bastante presente é a utilização do solo. Na Irlanda, por exemplo, as zonas com densidade populacional inferior a cem habitantes por quilômetro quadrado são consideradas rurais.. Na Grécia, o teto que separa as áreas rurais das urbanas é dado pela densidade populacional de trinta habitantes por quilômetro quadrado. O mesmo vale para o limite de duzentas habitações ou dez mil pessoas, na Dinamarca. Na Holanda e na Inglaterra, o principal definidor são as formas predominantes de utilização do solo. $\mathrm{Na}$ Alemanha é adotada uma tipologia que combina aspectos econômicos, demográfícos e a utilização do solo. E na Itália, por sua vez, o limite de dez mil habitantes é acompanhado de uma lista de treze critérios funcionais ${ }^{72}$.

Muitas destas definições são já bastante antigas e, em vários países, elas têm passado por tentativas de reclassificação, mais condizentes com as dinâmicas sócio-econômicas e ambientais contemporâneas. Uma das principais inovações foi elaborada por instituições de

\footnotetext{
${ }^{72}$ Estas informações foram reunidas pelo CEPFAR (Centre eurpopéen pour la promotion et la formation em milieu agricole et rural), citado por Mathieu (1990: 214), apud Wanderley (2000).
} 
pesquisa francesas. Ali, o critério clássico, de tamanho populacional, neste caso de duas mil pessoas, tem nada menos do que um século e meio de existência. $\mathrm{O}$ aumento da mobilidade e a crescente integração entre estas pequenas aglomerações e centros urbanos maiores ou com localidades vizinhas, tornou necessário aprofundar a combinação entre critérios estruturais e funcionais visando dar conta da nova dinâmica. Foi assim que, ainda nos anos sessenta, o INSEE (Institut National de la Statistique et des Études Économiques) formulou a noção de ZPIU - Zonas de Povoamento Industrial ou Urbano -, que se apóia na proporção de trabalhadores de uma determinada comuna que tem empregos fora de seu lugar de moradia e na parcela de domicílios dependentes da agricultura.

Com base neste critério, as comunas rurais puderam ser divididas entre aquelas situadas dentro das ZPIU e o rural profundo, isto é, aquelas situadas fora destas zonas. A simples classificação de acordo com o critério populacional permitiu identificar o tamanho dos espaços rurais franceses como algo em torno de um quarto da população no início dos anos 90. Mas os contrastes entre diferentes tipos de espaços rurais, como aqueles situados nas adjacências de áreas intensamente urbanizadas e povoadas e os localizados em áreas mais remotas, ficava sem possibilidade de apreensão pelas estatísticas e classificações oficiais. Por isso, em 1996 foi introduzida uma nova definição: o Zoneamento em Áreas Urbanas (ZAU). Com ela, os espaços urbanos passaram a ser categorizados em dois grupos: os "pólos urbanos", onde há uma oferta de pelo menos cinco mil empregos; a "coroa periurbana", formada pelas comunas nas quais ao menos $40 \%$ da população ativa trabalha nos pólos urbanos ou nas comunas sob sua influência. Juntas, estas duas categorias formam o espaço predominantemente urbano, o que no caso francês significava três quartos da população à época. De outro lado, também os espaços rurais tiveram sua delimitação mais refinada, sendo agora dividido em quatro categorias: O "rural sob fraca influência urbana", formada por comunas onde pelo menos $20 \%$ da população ativa trabalha num centro urbano próximo; os "pólos rurais", pequenas localidades que oferecem entre dois e cinco mil empregos e que, portanto, comportam mais postos de trabalho do que habitantes, revelando-se um local de atração; a "periferia dos pólos rurais", com as comunas nas quais pelo menos $20 \%$ da população trabalha nos pólos; e finalmente, o "rural isolado", que no caso francês representa 10\% da população total ou aproximadamente um terço do território (INRA/INSEE, 1998). 
Nos Estados Unidos, por sua vez, coexistem duas classificações oficiais: a do U.S. Census Bureau e a do Office of Management and Budget (OMB). A classificação do U.S. Census Bureau lida com dados decenais e tem um caráter censitário. Nela as áreas urbanas são as mais adensadas, mas não correspondem a divisões político-administrativas e podem ser de dois tipos: áreas urbanizadas ou "clusters urbanos". Numa área urbanizada deve haver mais de cinquenta mil pessoas, mesmo que não haja cidade com esse número de habitantes, e um núcleo com densidade superior a trezentos e oitenta e seis habitantes por quilômetro quadrado, podendo haver uma zona adjacente com um mínimo da metade dessa densidade. Já os “clusters urbanos" são localidades com população entre duas mil e quinhentas, e cinqüenta mil pessoas, mas que atinjam os mesmos níveis de densidade demográfica. A população rural é definida com sendo aquela que está fora tanto das áreas urbanizadas quanto dos "clusters urbanos". Em 2000, 68\% da população americana vivia em quatrocentas e cinqüenta e duas áreas urbanizadas, 11\% em “clusters urbanos”, e 21\% nas áreas rurais (Veiga, 2004).

Já a classificação da OMB baseia-se em dados anuais de população, emprego e renda e tem um caráter político-administrativo. Nela são separados essencialmente condados metropolitanos (metro) e não metropolitanos (nonmetro). Um condado é considerado economicamente ligado a uma aglomeração metropolitana se $25 \%$ dos trabalhadores residentes estiverem ocupados nos condados centrais, ou se $25 \%$ de seus empregados fizerem o "movimento pendular inverso". Além disso, os condados "nonmetro" são subdivididos em duas categorias: as "micropolitan areas" (centradas em núcleos urbanos com mais de dez mil habitantes) e "noncore" para o restante dos condados (Veiga, 2004).

Outra classificação que merece destaque é aquela oferecida pela OCDE. Após analise de estatísticas referentes a cinqüenta mil comunidades das duas mil microrregiões existentes nos países membros, a equipe de seu Serviço de Desenvolvimento Territorial passou a distinguir dois níveis analíticos. No nível local são classificadas como urbanas ou rurais as menores unidades administrativas, ou as menores unidades estatísticas. No nível micro-regional as agregações funcionais são classificadas como mais urbanas, mais rurais, ou intermediárias. Rurais são aquelas localidades cuja densidade populacional é inferior a cento e cinqüenta habitantes por quilômetro quadrado, com a exceção do Japão, onde este número sobe para trezentos e cinqüenta. Assim, as micro-regiões consideradas "predominantemente rurais" são aquelas em que a participação da população residente em localidades rurais excede 50\%; as 
micro-regiões "significativamente rurais", por sua vez, são aquelas em que a participação das localidades rurais fica entre 15 e $50 \%$; e as "predominantemente urbanas", por fim, aquelas onde as localidades rurais representam menos de $15 \%$ da população. Esta tipologia proposta pela OCDE é menos refinada do que outras existentes, mas tem a grande vantagem de cobrir um número expressivo de países e, com isso, oferecer possibilidades de comparação entre eles, como mostra a Tabela 1 a seguir. E é importante notar na Tabela 2, como a esta classificação não corresponde um alinhamento setorial, o que se observa pela distribuição dos empregos nos três grupos. 
Tabela 1

População rural nos países da OCDE, 1990

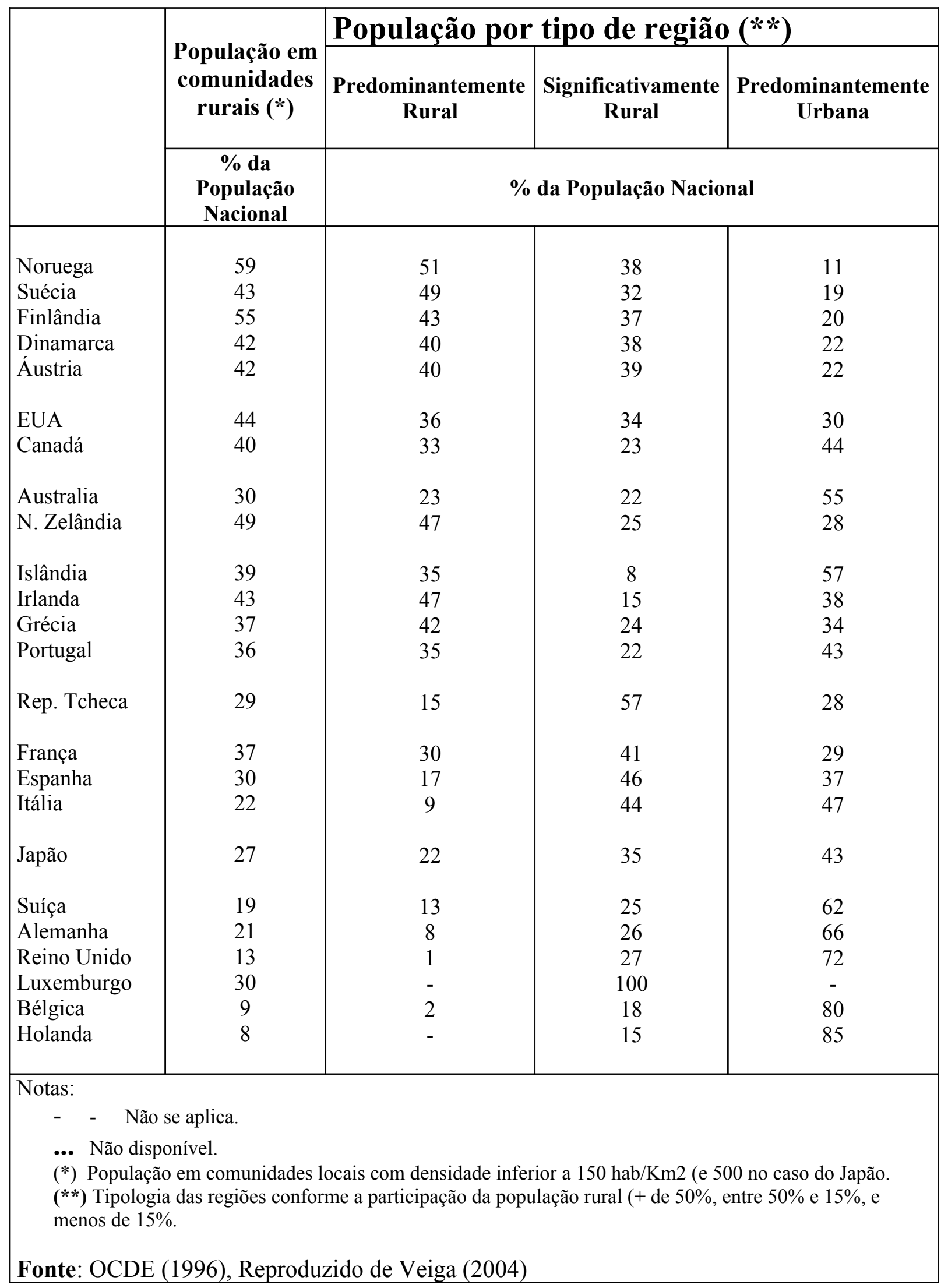


Tabela 2

Distribuição do emprego por setores econômicos nas regiões rurais dos países da OCDE, 1990

\begin{tabular}{|c|c|c|c|}
\hline & \multicolumn{3}{|c|}{ REGIÕES PREDOMINANTEMENTE RURAIS (*) } \\
\hline & Agropecuária & Indústria & Serviços \\
\hline & \multicolumn{3}{|c|}{$\%$ do emprego total } \\
\hline Noruega & 8 & 33 & 59 \\
\hline Suécia & 5 & 32 & 63 \\
\hline Finlândia & 16 & 30 & 54 \\
\hline Dinamarca & 10 & 30 & 61 \\
\hline Áustria & 13 & 37 & 49 \\
\hline EUA & 6 & 26 & 68 \\
\hline Canadá & 11 & 23 & 66 \\
\hline Australia & 15 & 20 & 65 \\
\hline Nova Zelândia & 17 & 24 & 59 \\
\hline Islândia & 37 & 21 & 42 \\
\hline Irlanda & 22 & 29 & 50 \\
\hline Grécia & 37 & 24 & 39 \\
\hline Portugal & 23 & 31 & 47 \\
\hline República Tcheca & 22 & 41 & 88 \\
\hline França & 11 & 32 & 57 \\
\hline Espanha & 25 & 25 & 50 \\
\hline Itália & $\ldots$ & $\cdots$ & $\ldots$ \\
\hline Japão & 14 & 31 & 55 \\
\hline Suíça & 10 & 33 & 57 \\
\hline Alemanha & 2 & 52 & 46 \\
\hline Reino Unido & 10 & 28 & 62 \\
\hline Luxemburgo & 3 & 31 & 66 \\
\hline Bélgica & 11 & 21 & 69 \\
\hline Holanda & 10 & 34 & 56 \\
\hline \multicolumn{4}{|l|}{ Notas: } \\
\hline \multicolumn{4}{|l|}{$\begin{array}{l}\text {... Não disponível. } \\
\text { (*) Tipologia das re }\end{array}$} \\
\hline
\end{tabular}


O primeiro destaque derivado da apresentação desta formas de classificação tem sido bastante sublinhado nos trabalhos que tratam do problema: o tamanho do rural mesmo no auge da urbanidade. Como se pode observar na Tabela 1, no conjunto dos países da OCDE, a população vivendo em comunidades rurais varia de um mínio de $8 \%$ na Holanda, até um máximo de 59\% na Noruega, e na maior parte dos países este percentual fica entre 20 e 45\%. Quando se trata de adotar a classificação por regiões rurais, observa-se que há uma grande heterogeneidade, mas nenhuma situação onde a proporção da população vivendo nas ares predominantemente ou significativamente rural seja desprezível.

O segundo destaque não é tão evidente, e diz respeito ao significado destas formas de classificação. Fundamentalmente, o que há de comum nas novas tentativas empreendidas seja pela OCDE, pelo INSEE ou pela OMB, é a busca em ultrapassar as definições substantivistas do rural, passíveis de serem expressas em um único critério ou dimensão, para formas onde seja possível vislumbrar seu conteúdo relacional ao urbano e às dinâmicas sociais e econômicas que lhe envolvem. Uma tarefa incontornável diante da mobilidade e da integração crescente entre os espaços. Algo que permite, para usar os termos do INSEE (1998), falar dos "campos e suas cidades". E para isso, torna-se necessário utilizar combinações de critérios estruturais e funcionais, e cobrir aspectos relativos às dimensões econômica, social, ambiental e demográfica. O principal significado subjacente a estes movimentos nos quadros cognitivos de apreensão e classificação é o crescente esvaziamento de sentido do rural como sinônimo de agrícola e de agrário e, em seu lugar, a emergência de uma visão territorial, o que implica tanto o reconhecimento de uma lógica econômica cada vez mais intersetorial, como uma escala geográfica de ocorrência de tais processos que remete à idéia de região.

Antes de analisar as implicações teóricas e sociais desta passagem, é importante completar o quadro empírico com um reconhecimento das manifestações heterogêneas das tendências recentes da nova ruralidade e interrogar as razões da diferenciação entre estes territórios.

\section{2 - As tendências recentes}

No capítulo anterior já foi dito que as tendências recentes vividas nas áreas rurais poderiam ser qualificadas como um novo momento na longa evolução destes espaços. Uma nova etapa 
onde as três dimensões definidoras da ruralidade sofrem um deslizamento em seus conteúdos sociais e na qualidade de sua articulação, com destaque para uma maior integração entre o urbano e o rural e para uma nova ancoragem ambiental da ruralidade. Posteriormente, na primeira seção do presente capítulo, foi possível ter uma idéia do tamanho dos espaços rurais nos países do capitalismo avançado e da maneira heterogênea como a população está distribuída nestas áreas e nas áreas urbanas. Trata-se agora de explorar como aquelas tendências gerais se manifestam de maneira desigual nestes territórios particulares.

As mudanças que estavam em curso no último quarto do século $\mathrm{XX}$ nos países do capitalismo avançado foram rapidamente percebidas. O desgaste da política agrícola de viés exclusivamente setorial começa a surgir nos meados dos anos 80 e abre espaço para uma série de reformas e debates sobre "O futuro do mundo rural", não por acaso título do Comunicado da Comissão Européia ao Parlamento, em $1988^{73}$. Um marco inegável foi a criação do Programa Leader - Ligações Entre Ações de Desenvolvimento das Economias Rurais -, em 1991, e ainda hoje a principal referência de programas territoriais de desenvolvimento rural. Mas as melhores sínteses da percepção dos organismos de planejamento sobre tais mudanças foram expressas em dois momentos, no meio da década de 90: a conhecida "Declaração de Cork", que saiu da conferência "A Europa Rural Perspectivas de Futuro" e o workshop Post-Industrial Rural Development: The Role of Natural Resources and the Environment, cujos resultados foram publicados pelo North Central Regional Center for Rural Development, da Universidade de Iowa.

Veiga (2004) resumiu o conteúdo destes dois momentos no quadro a seguir, qualificando-o como uma espécie de consenso básico sobre a ruralidade avançada.

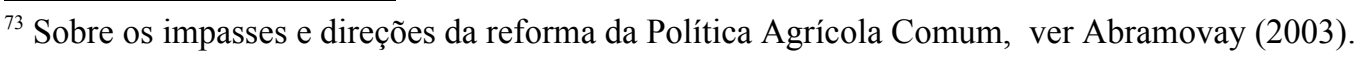




\section{Quadro 3}

\section{Consenso básico, de meados dos anos 1990, sobre a ruralidade avançada}

1. As zonas rurais, que englobam os locais de residência de um quarto da população européia e de mais de um quinto da americana, e mais de $80 \%$ dos dois territórios, caracterizam-se por tecidos culturais, econômicos e sociais singulares, um extraordinário mosaico de atividades e uma grande variedade de paisagens (florestas e terras agrícolas, sítios naturais incólumes, aldeias e pequenas cidades, centros regionais, pequenas indústrias, etc.).

2. As zonas rurais, bem como os seus habitantes, formam uma autêntica riqueza para suas regiões e países e podem ser bem competitivas.

3. As maiores partes dos espaços rurais europeus e norte-americanos são constituídos por terras agrícolas e florestas que influenciam fortemente o caráter das paisagens.

4. Dado que a agricultura certamente permanecerá como importantíssima interface entre sociedade e ambiente, os agricultores deverão cada vez mais desempenhar funções de gestores de muitos dos recursos naturais dos territórios rurais.

5. Mas a agricultura e as florestas deixaram de desempenhar papel predominante nas economias nacionais. Com o declínio de seus pesos econômicos relativos, o desenvolvimento rural mais do que nunca deve envolver todos os setores sócio-econômicos das zonas rurais.

6. Como os cidadãos europeus e norte-americanos dão cada vez mais importância à qualidade de vida em geral, e em particular a questões relativas à saúde, segurança, desenvolvimento pessoal e lazer, as regiões rurais ocuparão posições privilegiadas para satisfazer tais interesses, oferecendo amplas possibilidades de um autêntico desenvolvimento, moderno e de qualidade.

7. As políticas agrícolas deverão de se adaptar às novas realidades e desafios colocados, tanto pelos desejos e preferências dos consumidores, quanto pela evolução do comércio internacional. Principalmente uma adaptação que impulsione a transição de um regime de sustentação de preços para um regime de apoios diretos.

8. Os subsídios estabelecidos pelas respectivas políticas agrícolas serão crescentemente contestados. E já é ampla a aceitação de que apoios financeiros públicos devam ser cada vez mais condicionados a uma adequada gestão dos recursos naturais, e à manutenção e reforço da biodiversidade e das paisagens culturais.

9. As reformas das políticas agrícolas da primeira metade da década de 1990 conservaram inconsistências, duplicações e alta complexidade jurídica, apesar de inegáveis avanços em termos de transparência e eficácia.

10. Torna-se absolutamente necessário promover a capacidade local de desenvolvimento sustentável nas zonas rurais e, nomeadamente, iniciativas privadas e comunitárias bem integradas a mercados globais.

Reproduzido de Veiga (2004)

Como se pode observar, este largo consenso sobre a ruralidade avançada combina elementos relativos tanto à visão agrícola e produtivista como à visão territorial do desenvolvimento rural. Desde então, várias foram as pesquisas que procuraram delinear a manifestação destas tendências e sua ocorrência desigual a partir do estudo de realidades concretas. 
O fator mais enfatizado, condizente com o estatuto da nova ruralidade, tem sido a disponibilidade de amenidades naturais como principal vantagem comparativa. McGranahan (1999) mostra como as amenidades rurais são o principal vetor de mudança. Entre 1970 e 1996 a média do crescimento populacional nos condados não metropolitanos com alta atratividade baseada em amenidades foi de $120 \%$, enquanto naqueles com baixa atratividade este percentual ficou em mísero $1 \%$. Da mesma forma, este autor mostra como mudanças na oferta de empregos tem correspondência com a presença de amenidades. Mais interessados no próprio crescimento econômico de parte das áreas rurais, Aldrich \& Kusmin (1997) concluíram que, onde isso ocorreu, o principal fator foi a capacidade de atrair aposentados, algo também totalmente ligado às amenidades naturais típicas do rural. Junto disso, um segundo fator igualmente enfatizado nestas e em várias pesquisas é a localização. Dados sobre emprego mostram que as áreas adjacentes aos espaços urbanos têm maior crescimento. Exatamente as regiões que a OCDE classificou como significativamente rurais.

Claro que nem tudo é dinamismo e conciliação entre sociedade e natureza nestas tendências. Kayser (1990) chama a atenção para o processo de descampezinização inerente a esta nova ruralidade e o que isso significa em termos de diluição de um mundo estruturado em torno desta forma social tão importante para a história rural européia. Há mesmo toda uma série de interessantes pesquisas destinadas a denunciar e, às vezes, explicar fatores de degradação e pobreza $^{74}$. Mas, mais importante do que revelar os contrastes, é interrogar porque certas coisas acontecem ali, onde não se esperaria que elas ocorressem. Debruçados sobre a situação da Suécia, Ceccato \& Person (2002) concluíram que em todas as áreas do país há inserção dos diferentes ramos econômicos, embora de maneira variada. É certo que as regiões de melhor performance tendem a se incluir nos ramos de atividades privadas tradicionais, enquanto áreas de baixa performance tendem a se apoiar nas atividades públicas, sobretudo no caso de áreas mais esparsamente povoadas. A surpresa por eles trazida é que alguns clusters modernos estão sobrerepresentados em algumas destas áreas de menor densidade. Esta constatação, que encontraria similares em estudos sobre outras realidades na Europa e EUA, revela na verdade que não há associação automática entre grau de urbanização e

\footnotetext{
${ }^{74}$ Como demonstram Cecchi (1999) para a realidade italiana, Shucksmith \& Chapman (1998) e Oughton, Wheelock \& Baines (2003) para o Reino Unido, ou Commins (2004) para a Irlanda. Sinais de deterioração, pobreza e declínio certamente podem ser encontrados também nas áreas rurais americanas, como se pode ver em Mitchell (1998), ou em uma enfática matéria assinada por Timothy Egan no The New York Times, em 2002, e que traz o enfático título Drugs, crimes and poverty plague rural U.S.
} 
ocorrência de bons indicadores. E isto, leva à seguinte pergunta: se é verdade que localização e disponibilidade de amenidades naturais são as principais vantagens comparativas, o que faz com que elas se transformem em vantagens competitivas?

\section{3 - As razões do desenvolvimento}

Para Kayser (1990), a chave deste desenvolvimento das áreas rurais está no fator populacional e nos efeitos de enriquecimento da sociedade em geral. Para Basile \& Cecchi (1997) a questão está na diferenciação produtiva, na mudança da composição setorial da economia das áreas rurais até a emergência das atividades não agrícolas: diferenciação traz novos atores, nova formas de uso dos recursos naturais, novas relações entre atores e entre setores, além de novos modos de integração do rural ao sistema econômico. O que estes estudos, e tantos outros que poderiam aqui ser citados, não respondem é justamente porque estes efeitos não são generalizáveis para o conjunto de áreas rurais. E isto, pelo simples fato de que não era esta a pergunta que está na base de seus esforços.

Mas há, desde os anos 70, diferentes programas de pesquisa tentando encontrar estas respostas: os estudos dedicados à compreensão dos fenômenos de desenvolvimento rural, propriamente ditos, aqueles consagrados à análise dos fenômenos de industrialização difusa, e aqueles destinados a compreender os fatores de êxito e fracasso das tentativas de indução ao desenvolvimento. As linhas a seguir visam apresentar brevemente os resultados destes programas para, ao final, compilar uma síntese das principais lições com eles obtidas.

\subsection{1 - Lições dos programas de pesquisa}

\section{A industrialização difusa}

Uma explicação com decisiva influência sobre o desenho de programas e projetos pode ser encontrada nos estudos sociológicos e econômicos que têm enfatizado o papel dos sistemas produtivos locais na geração de um certo tipo de empreendedorismo. O marco é o estudo do sociólogo italiano Arnaldo Bagnasco, Tre italie. La problematica territoriale dello sviluppo italiano, de 1977. Neste livro já clássico, ele procura explicar porque, naquele momento, as regiões que apresentavam indícios de dinamismo não eram nem o sul do país, cujos problemas históricos se materializam naquilo que Gramsci chamou de "questão meridional", 
nem o norte, fortemente industrializado, mas a região central do país. A principal contribuição dos estudos originários desta terceira vertente está em chamar a atenção para as características morfológicas de determinados territórios e sua importância no estabelecimento da dinâmica econômica local. O centro do argumento está em que, no caso italiano, constatou-se uma forte relação entre a distribuição espacial da chamada "economia difusa", marcadamente um grande número de pequenas e médias empresas, associadas com a existência de uma forte base familiar entre as unidades de produção agrícola, e com um determinado padrão de urbanização que evitava uma fratura cidade-campo. A ele se seguiram vários outros de sociólogos, economistas e geógrafos analisando a formação dos chamados distritos industriais ${ }^{75}$. Brusco (1996), particularmente, enfatiza como estas condições estruturais se transformam num ambiente que associa competição com colaboração, conflito com participação, e conhecimento local e prático com conhecimento científico.

Mas estas mesmas características enaltecidas como trunfos nos estudos acima citados tornaram-se advertência quando os estudos sobre a realidade italiana começaram a servir de inspiração para tentativas de dinamização de regiões estagnadas. Com razão, Garofoli (1996) destacava que as condições existentes no caso da Terceira Itália não se encontravam em qualquer lugar e que são de difícil reprodutibilidade. E, paralelamente, outros programas de pesquisa (Maillat, 1995), estimulados pelo mesmo tipo de questão, mostraram que ambientes inovadores podiam ser encontrados nas mais distintas configurações produtivas. Qual é a chave do sucesso, então?

Infelizmente os estudos de Maillat e outros que o acompanharam (Becattini \& Rullani, 1995; Sforzi, 1996) descrevem bem as mudanças em curso e o tipo de arranjo por detrás delas, mas pouco se sabe sobre o que é capaz de gerar um novo modo de produção e de organização das forças locais $^{76}$. O que é comum a todos estes estudos é a importância conferida ao enraizamento da atividade econômica no conjunto de relações que conformam os territórios em que elas se inserem. Uma associação que encontrou sua melhor expressão na conjugação capital social e territórios (Abramovay, 2000).

\footnotetext{
${ }^{75}$ Uma boa análise da trajetória destes estudos pode ser encontrada em Veiga (1999). Duas importantes coletâneas reúnem boa parte dos mais importantes teóricos que têm produzido sobre o tema dos distritos industriais e dos sistemas produtivos locais nas três vertentes disciplinares apontadas: Benko \& Lipietz (1992; 2000).

${ }^{76}$ Ver a respeito a excelente crítica de Martin \& Sunley (2001) a Porter.
} 
Apesar dos impasses e das nuances, nas diferentes vertentes que estudam este fenômeno, há duas idéias principais. Uma enfatiza os efeitos de proximidade e o que eles trazem em termos de cooperação e aprendizagem, ambas condição para gerar uma base endógena capaz de resultar em inovação e coesão entre agentes. A outra vai acentuar mais a diversificação e a desconcentração do tecido social local e as interdependências existentes entre características das estruturas sociais e o tipo de interações que nelas ocorre.

\section{Rural development in the USA}

Um dos principais livros sobre o desenvolvimento rural no mundo contemporâneo é justamente consagrado à análise da realidade dos EUA - Rural Development in the United States, de Galston \& Baehler (1995). Nele, os autores destacam como, ao longo da história americana, foram mudando as vantagens comparativas das áreas rurais. Numa primeira longa etapa da formação do território americano a grande vantagem comparativa estava situada na disponibilidade de produtos primários: madeira, carvão, minerais, produtos agrícolas. A busca por estes recursos orientou a ocupação do espaço e foi, por bom tempo, a principal fonte de trabalho e riqueza. Obviamente, com o passar do tempo a importância desta produção foi decrescendo, tanto em termos de pessoal ocupado como de riqueza gerada. As inovações tecnológicas e a consolidação de cidades deram lugar a uma diversificação da base produtiva, com o desenvolvimento crescente de atividades de transformação e serviços. Nesta etapa, os espaços rurais passam a ter nos seus terrenos e mão-de-obra mais baratos e em aspectos como menor fiscalização e sindicalização fatores de atração de indústrias e investimentos. A principal vantagem passa a ser a localização, já que o aproveitamento destes fatores menos onerosos nas áreas rurais só eram compensadores em razão de uma certa distância dos centros mais dinâmicos, compensando custos de transporte. Mas da mesma maneira que o avanço tecnológico permite uma diminuição de custos de produção e a introdução de técnicas poupadoras de mão-de-obra na agricultura, na atividade manufatureira acontece o mesmo. Com isso, o dinamismo passa a se concentrar no setor terciário.

Nas duas últimas décadas do século passado, foram os condados que mais oferecem serviços ligados ao aproveitamento de amenidades rurais - paisagens naturais ou cultivadas, ar puro, água limpa, atrativos culturais - aqueles que apresentaram maior crescimento. Evidentemente a agricultura de commodities continua tendo um peso enorme na conformação dos espaços 
rurais e, igualmente, atividades terciárias sempre existiram neste meio. O que destacam Galston \& Baehler é a ênfase crescente neste segundo conjunto, tanto em termos de pessoas ocupadas, como de riqueza gerada, mas, principalmente, pelo que ela traz de novo para as instituições voltadas ao desenvolvimento rural: a importância crescente da natureza e dos valores não diretamente monetarizáveis.

Mas é claro também, e os autores estão atentos para isso, que nem todas as localidades rurais têm as mesmas condições de experimentar um processo de desenvolvimento baseado na exploração de suas amenidades. A baixa densidade populacional, característica básica destes espaços, é um dificultador da diversificação econômica. Da mesma forma, distância de centros urbanos também pode se converter em desvantagem pelo aumento nos custos de informação e transporte. Por isso os autores, a par da ênfase nos atributos específicos destes territórios, chamam igualmente a atenção para a forma de inserção destas localidades no espaço extra-local, ou, como preferem Galston \& Baehler, a relação entre as regiões rurais com as cidades ou com outras partes do mundo.

Aqui há uma forte influência de Jane Jacobs (1984): é a economia da cidade que molda a economia das regiões rurais. E isto acontece pela exportação de produtos primários, pela atração de atividades de transformação, ou pela captação da renda de setores urbanos, como aposentados, profissionais liberais, estes em busca de segunda residência, ou via atividades turísticas. O fato é que, quanto mais estreitas forem estas relações, mais chance de prosperidade elas têm. $\mathrm{O}$ crescimento de empregos nos condados adjacentes às regiões metropolitanas, duas vezes superior aos condados mais distantes, como verificado nos anos oitenta, corrobora esta afirmação.

Sobre as áreas que estão fora desta proximidade, não há fatalismo, ao menos nos autores americanos. Para eles é possível "criar" uma articulação entre regiões rurais e uma rede de cidades, ou a constituição de uma rede de cidades numa região rural: isto pode ser feito através de investimentos em comunicação e transporte, diminuindo distâncias, através de uma espécie de divisão territorial do trabalho entre pequenas localidades, tentando suprir necessidades que teriam que ser satisfeitas em centros urbanos. Ou, ainda, através da geração dos próprios pólos de crescimento, com a formação de cidades que venham a suprir estas necessidades. 
Em qualquer uma destas possibilidades, novamente a palavra-chave é diversificação. É isto que garante o suprimento da população local, que cria as condições para a introdução de inovações e a adaptação destes territórios às pressões e contingências advindas das mudanças econômicas mais gerais ${ }^{77}$.

\section{Dynamics of rural areas - The DORA Project}

Um dos mais interessantes programas de pesquisa sobre desenvolvimento rural reúne os estudos feitos pelo The Arkleton Centre for Rural Development Research, da Universidade de Aberdeen, no Reino Unido, sobre a diferenciação da performance econômica em áreas rurais européias - o DORA Project: Dynamics of rural áreas -, cujos resultados foram sintetizados em Bryden \& Hart (2001). Ali os pesquisadores procuraram considerar a ocorrência dos "soft factors", por eles chamados também de "fatores não tangíveis" em combinação com a ocorrência de "hard factors", ou, segundo a linguagem adotada pelo projeto, "fatores tangíveis".

No rol dos "fatores tangíveis" foram incluídos: recursos naturais (terra), recursos humanos (trabalho), infra-estrutura (tecnologia), investimento (capital), e estruturas econômicas. Entre os "fatores não-tangíveis" estavam: performance de Mercado, performance institucional, redes, comunidade e qualidade de vida (Bryden et al, 2001). Este tableau de fatores foi transformado em uma série de indicadores postos à prova por equipes de pesquisadores em oito regiões de quatro diferentes países europeus - Suécia, Alemanha, Escócia e Grécia.

Três são os principais méritos deste programa. Primeiro, procurou-se superar a dicotomia entre estudos quantitativos e qualitativos, buscando uma análise combinada dos dois métodos. Segundo, a pesquisa apoiou-se num procedimento comparativo envolvendo duas realidades do mesmo país e, junto disso, o contraste analítico com a realidade entre distintos países. Terceiro, foram contemplados no rol de indicadores dimensões até então operadas somente de maneira isolada em estudos específicos, o que permitiu um balanço da efetividade de cada uma delas.

\footnotetext{
${ }^{77}$ E é aqui também que os autores se distanciam de Jacobs (1984), para quem, como já foi dito, estes atributos só podem ser supridos pelas cidades, pois somente elas reuniriam as condições necessárias para isto: concentração, proximidade, usos combinados do espaço .
} 
A principal hipótese do estudo foi confirmada pelas análises de campo: certamente fatores como o distanciamento influenciam, mas as causas da performance diferenciada das economias rurais vão além dos fatores objetivos enfatizados pelas análises clássicas, tanto quanto pelas teorias baseadas no fenômeno de localização. Mesmo regiões pouco privilegiadas em termos de densidade populacional e localização tiveram desempenho acima das previsões em geração de emprego. Isto ocorreu, por exemplo, nas ilhas Orkney, na Escócia, ou na grega Korinthia.

Viu-se, assim, que a incidência das variáveis individuais diz muito pouco sobre o conjunto das situações, sendo necessária a sua análise combinada com outras. Nisto, os componentes ligados à dimensão cultural mostraram forte influência, por exemplo, quando associados a qualidades empreendedoras ou a capacidade de adaptação a mudanças e contingências externas. Além disso, o estudo conseguiu identificar que estes componentes culturais, por sua vez, estão muitas vezes enraizados em um quadro de referências de muito longa formação.

O estudo mostrou ainda que, mais importante do que os aspectos físicos, é a busca de aproveitamento dos fatores não reprodutíveis de um determinado território, como produtos e marcas típicas ou como bens culturais. As redes, fator tão enfatizado em boa parte da literatura, foram tratadas como algo ambíguo no âmbito deste projeto: muitas vezes são elas que bloqueiam o acesso dos agentes locais a outras formas de inserção mais promissoras, contribuindo assim para manter situações de estagnação ou de dependência.

\section{Ruremplo}

Com tantas perspectivas explicativas concorrentes seria bom poder contar com um teste de conjunto das hipóteses apresentadas em cada uma delas. Pois foi justamente isto o que fez o Ruremplo (Terluin, 2003; Terluin \& Post, 2003).

Dez variáveis relativas a sete diferentes corpos teóricos foram testadas em dezoito regiões rurais. O resultado final mostrou uma maior aderência empírica das hipóteses contidas nos trabalhos de Bryden, do DORA Project, na chamada community-led theory, e na abordagem que mescla um enfoque endógeno e exógeno. O núcleo comum das três teorias reside na 
articulação entre determinadas características do tecido social e econômico dos territórios em questão e o tipo e a qualidade das relações estabelecidas com o espaço extra-local. No outro extremo, as teorias mais fortemente ancoradas em fatores como localização, disponibilidade de infra-estrutura, PIB per capita ou nível de investimentos mostraram-se de menor poder explicativo.

Será que as conclusões apontadas por estes programas de pesquisa estariam sendo observadas nas tentativas de indução do desenvolvimento rural através de políticas como o Leader, na União Européia, ou o EZ/CZ, nos Estados Unidos?

\subsection{2 - lições da experiências de indução ao desenvolvimento rural}

\section{O Leader}

O Programa Leader surge em 1991, como Iniciativa Comunitária da União Européia, nos marcos de um amplo processo de discussão sobre as formas de planejamento de políticas naquele continente, crescentemente preocupado com as distorções entre regiões. Seu caráter inovador residiu, primeiro, no fato de tratar-se de algo com viés territorial, em oposição ao caráter marcadamente setorial dos investimentos tradicionalmente destinados às áreas rurais. E, segundo, no tipo de estratégia proposta para estas ações de promoção do desenvolvimento rural, com ações do tipo bottom-up, baseadas no princípio da parceria, e de caráter multisetorial e integradas. Esta estratégia se materializa no conceito de competitividade territorial e envolve: a estruturação dos recursos do território de forma coerente, o envolvimento de diversos atores e instituições, a integração entre setores empresariais em uma dinâmica de inovações, e a cooperação com outras áreas e políticas nos vários níveis de governo. De acordo com os termos do programa, a competitividade territorial se alcança através da elaboração de projetos de desenvolvimento que comportem uma visão de futuro, formas de coordenação dos atores, e a constituição de um grupo de ação local (Beduschi \& Abramovay, 2004).

Em sua primeira fase, de 1991 a 1994, o programa apoiou duzentos e dezessete projetos territoriais, número que saltou para mil projetos na fase seguinte, de 1994 a 1999. Estes projetos são apoiados por seu mérito, e não por pré-seleção, como uma maneira de estimular 
a competição entre territórios e a correspondente mobilização de energias e talentos na busca por estes recursos. Duas características essenciais têm sido, assim, valorizadas pelo Leader: a concepção de que o desenvolvimento rural pode ser alcançado através do planejamento e execução de projetos, e a importância de que isto aconteça segundo um enfoque participativo.

As primeiras lições sobre esta iniciativa mostraram uma tônica claramente positiva. Elas mostraram que a introdução do conceito de projeto territorial torna possível ir além da definição setorial, que o declínio pode ser revertido se a articulação territorial encontrar novos caminhos, e que o enfoque territorial tem estimulado a criatividade e uso dos conhecimentos locais. Mas o sucesso ou insucesso desse intento é atribuído apenas à maneira como são combinadas as expectativas dos atores sociais. Há, portanto, um viés claramente interacionista na estratégia preconizada. É como se bastasse pôr os agentes em contato, criando espaços e formas de apoio à sua articulação. Daí se criariam oportunidades e ligações dinâmicas capazes de melhorar a performance do território. O projeto de desenvolvimento territorial aparece como uma conseqüência do alinhamento de interesses.

Outros estudos mais recentes (Ray, 2001; Schattan et al 2005) têm chamado a atenção para uma espécie de "dark side" destes processos de indução ao desenvolvimento territorial. A lógica de seleção de projetos tende a reforçar as diferenças, à medida que os territórios já dotados de maior capacidade tendem a reunir melhores condições de proposição e assim angariar o apoio oferecido pelo programa. Além disso, a maneira como se dá a elaboração destes projetos de desenvolvimento e a própria articulação dos grupos locais tendem partir da base de recursos disponíveis para tais iniciativas. E um dos problemas para a dinamização de economias rurais, muitas vezes, é justamente a fragilidade dos recursos com os quais se pode contar para tais iniciativas.

Estas críticas revelam na verdade uma lacuna teórica na associação entre participação e desenvolvimento. Se por um lado há fortes evidências de que a participação contribui para a eficiência da aplicação de recursos em políticas sociais, por exemplo, onde há um público alvo e um foco específico, no caso das ações de desenvolvimento esta condição se revela muito mais complexa, pois são muitos os segmentos envolvidos e os interesses em conflito. E nesse caso, os processos participativos podem aumentar o poder de veto, mas não necessariamente de coesão entre agentes locais $^{78}$.

\footnotetext{
${ }^{78}$ Este argumento é desenvolvido em Schattan et al. (2005).
} 


\section{O EZ/CZ}

O EZ/CZ - Empowerment Zones / Entreprise Communities é um programa que guarda similaridades com o Leader e foi criado nos Estados Unidos em agosto de 1993. Uma diferença é que, para participar, as comunidades tem que apresentar altos índices de pobreza. Também aqui é preciso apresentar um projeto baseado nos seguintes princípios: oportunidade econômica, desenvolvimento sustentável, cooperação e parceria nas comunidades, visão estratégica de mudança (Beduschi \& Abramovay, 2004).

Há, sobre este programa, bem menos estudos divulgados do que no caso do Leader, mas, pelo seu desenho, é possível dizer que cabem as mesmas críticas, sobretudo aquelas relatias à ausência de uma sólida fundamentação para como se dão as relações virtuosas tão desejadas entre governança e desenvolvimento.

Apesar das perguntas ainda em aberto, não há dúvida que, os programas de pesquisa e as iniciativas públicas de desenvolvimento rural são, hoje, profundamente marcadas por uma lógica territorial. Os estudos sobre a performance diferenciada de áreas rurais mostraram claramente como as dinâmicas que respondem por sua direção obedecem claramente a fatores desta ordem. E as iniciativas de apoio e indução, como reflexo, têm claramente estimulado a adoção deste enfoque nos projetos por elas apoiados. Cabe, então, perguntar qual o significado desta emergência da abordagem territorial.

\section{3 - A emergência da abordagem territorial e seus significados}

A seção anterior mostrou uma situação paradoxal. Não há dúvida de que para o estudo dos fenômenos relativos ao desenvolvimento rural torna-se imprescindível uma abordagem territorial. Isto pode ser percebido pela definição dos conteúdos relativos à nova etapa do desenvolvimento rural, pelas tendências verificadas na ruralidade do capitalismo avançado, pelas categorias cognitivas que vem sendo criadas pela sociedade tanto para compreender como para induzir a performance destas áreas. O problema é que, apesar da profusão de estudos com este enfoque, não há propriamente falando uma teoria do desenvolvimento territorial: Midmore (1999) constroi uma abordagem que envolve globalização, 
internacionalização, territorialização, Cecchi (2002) enfatiza os sistemas locais como instrumento de análise e de inserção da economia rural no conjunto da economia global, Ray (2002) trabalha com uma abordagem territorial inspirada em componentes da teoria bourdiesiana (formas de capital) e neo-marxista (teoria dos modos de produção).

O que há, portanto, é uma abordagem territorial que se expressa, sobretudo, no tratamento de um determinado nível da realidade e na operacionalização de algumas instâncias empíricas fundamentais. A diferença no tom da introdução e conclusão dos dois volumes de coletâneas organizadas por Benko \& Lipietz $(1992 ; 2000)$ bem demonstram esta dificuldade. Enquanto no primeiro volume, do início dos anos noventa, a marca é um entusiasmo com as possibilidades que se abriam com estudos territoriais que viriam a se tornar referências obrigatórias nos anos seguintes, no segundo volume a tônica já recai sobre a dificuldade em transformar estas evidências em lições capazes de explicar as condições que fizeram com que experiências positivas enaltecidas em determinados estudos pudessem ali ocorrer.

Se a noção que fundamenta a abordagem é, do ponto-de-vista teórico, tão fugidia, surgem duas perguntas. Primeiro, por que tal enfoque se disseminou com tamanha rapidez e em diferentes partes do mundo ? Segundo, por que foi justamente a idéia de território quem ganhou proeminência, e não outras com uma ainda maior tradição, como a idéia de região, que apresenta tantos conteúdos similares e reúne uma maior especialização em torno de si ?

Sobre a primeira pergunta, além do reconhecimento das novas dinâmicas que estão subjacentes à emergência da abordagem territorial, destacas pelos programas de pesquisa apresentados páginas atrás, é preciso reconhecer que isto acontece num contexto histórico também marcado por uma certa crise e realinhamento dos instrumentos tradicionais de promoção do desenvolvimento. A descentralização das políticas e também da atividade industrial, associado à redução e a um certo redirecionamento da intervenção estatal contribuíram para que, particularmente nos meados dos anos 80 e nos anos 90, se instituísse um padrão onde, em lugar dos investimentos diretos e de corte setorial, caberia ao Estado criar condições e um certo ambiente a partir do qual os agentes privados pudessem, eles mesmos, fazer a alocação, supostamentemente mais eficiente, dos recursos humanos e materiais. Aqueles processos sociais e econômicos de corte eminentemente territorial e este 
novo padrão, são, em síntese, as principais razões da emergência e consolidação desta nova abordagem territorial ${ }^{79}$.

Sobre a segunda questão, é interessante contrastar a evolução e os significados de idéias com forte correlação, como região e território. Uma ótima sistematização da evolução e das mudanças no conceito de região pode ser encontrada no livro Região e Geografia, de Sandra Lencioni (2003). Nele, a autora mostra a origem da idéia ainda entre os gregos, como conhecimento corográfico voltado para as descrições das diferenças da superfície terrestre. Uma tradição que se funda com Estrabão, de ciência voltada para o desvendamento do mundo visando a satisfação das necessidades humanas e que seria muito útil ao espírito Iluminista, vários séculos depois. Como ramo institucionalizado, a emergência da geografia regional ocorreu em oposição ao universalismo da filosofia alemã. Esta cisão entre universal e particular, com o ramo disciplinar situando-se no segundo pólo, viria a ser superada posteriormente sob influência do positivismo lógico onde, através da fenomenologia e do marxismo, há uma reconciliação com as leis gerais.

Após o período de institucionalização, o declínio do conceito e do sub-campo disciplinar que se erigiu em torno dele tem por base duas críticas. Para Milton Santos (apud Lencioni, 2003: 192), nas condições atuais da economia universal, a região teria perdido o caráter de realidade viva, dotada de coerência interna. A ausência desta "autonomia regional" seria, assim, uma das razões da falência da geografia regional tal como considerada nos moldes clássicos. A segunda crítica diz respeito às fronteiras epistemológicas. Embora se situe no âmbito da ciência social, a geografia difere da teoria social à medida que considera os aspectos da natureza para a compreensão da realidade (Lencioni: 2003: 203). Enquanto a geografia humana sofreu uma espécie de hipertrofia, a geografia física continuou sua trajetória de valorização, impulsionada pela valorização dos temas ambientais e ecológicos. De outro lado, a geografia regional, ante o entendimento da geografia como ciência social, sem atentar para sua especificidade que consistia em incorporar a natureza, acabou sendo negada. Isto é, a especificidade da geografia precisava ser esquecida para sua afirmação como ciência social. Finalmente, em afinidade com este espírito dos tempos, o descenso do planejamento regional, em muito relacionado à primeira destas críticas, completa o quadro de esvaziamento da legitimidade do uso do conceito de região na geografia.

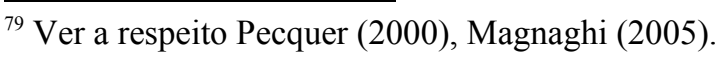


Contra este movimento, Lencioni parece sugerir a volta da geografia regional como uma espécie de ciência de síntese: entre leis gerais e suas manifestações particulares, entre natureza e sociedade. Mas recoloca-se assim o problema de fundo que diz respeito às fronteiras entre mundo natural e mundo social: elas podem ser transpostas nos limites de uma disciplina?

Entende-se, assim, parte das razões que levam a substituir região por território na retórica e nos estudos sobre desenvolvimento: a referência privilegiada da idéia de território se estabelece com a política, que enquanto tal não resvala na difícil questão dos limites e da especialidade disciplinar. Tanto é que a idéia de território apresenta ramificações na biologia, na etologia, na antropologia, na política e na história, além da geografia e da sociologia.

Apesar da importância do enraizamento espacial das sociedades humanas, Hasbaert (2004), na melhor sistematização disponível dos vários usos do conceito, considera que o tema da territorialidade foi praticamente negligenciado até 1976, com o lançamento do livro Territorialidade Humana, de Torsten Malmberg. Numa espécie de síntese destes enfoques, Hasbaert destaca os elementos valorizados em cada uma das tradições existentes. Na política, território é sempre referido às relações espaço-poder em geral ou às questões de ordem jurídico-política. É esta a visão mais difundida, onde prevalece uma visão de território como espaço delimitado e controlado. Na abordagem cultural, muitas vezes culturalista, a ênfase recai sobre o simbólico-cultural que permeia a experiência do território vivido, como apropriação. A dimensão econômica, menos difundida, sublinha a dimensão espacial das trocas; território é visto como fonte de recursos ou incorporado no debate entre classes, como uma expressão da divisão do trabalho. Finalmente, há ainda uma abordagem natural, marcada pelas relações sociedade e natureza, onde se aborda o comportamento natural dos homens em relação ao seu ambiente físico.

Evidentemente, algumas destas linhas ou enfoques podem ser combinados, visando constituir um corpo teórico capaz de iluminar os aspectos para os quais se tem chamado a atenção. $\mathrm{O}$ fato é que, deste ponto-de-vista, seja através da idéia de região, seja através da idéia de território, trata-se, sobretudo, menos de uma teoria e mais de uma escala dos processos sociais e de um conjunto de instâncias empíricas a serem mobilizadas para a explicação. 
Pierre Bordieu (2001:124), lembra que o regionalismo, como uma categoria que remete a processos sociais situados numa escala espacial, é apenas mais um caso de lutas propriamente simbólicas em que agentes, seja envolvidos individualmente e de maneira dispersa, seja coletivamente e de maneira organizada, levam adiante um jogo de conservação ou transformação das relações de força simbólicas e das vantagens correlativas, tanto econômicas como, também, simbólicas. Não se deve esquecer que há uma economia do simbólico irredutível à economia em sentido restrito, e que as lutas simbólicas têm fundamentos e efeitos econômicos, também em sentido restrito, efetivamente reais (Bourdieu, 2001-a: 129). Para complicar ainda mais, como lembra Jacobs (2001), nesta trama espacial é preciso ainda incluir uma certa natureza das economias e uma economia da natureza.

A compreensão a contento dos fenômenos territoriais leva à necessidade de concebê-los como um campo, no sentido mesmo dado por Bourdieu, como um todo estruturado de posições e oposições, cuja configuração é determinada pela distribuição desigual dos diferentes trunfos, entre os agentes e grupos sociais que o compõem. A dinâmica do território, no que diz respeito às lutas sociais, será sempre dada pela busca pela melhor posição de cada agente individual no interior deste território e, deste território em relação aos demais. Complementarmente, mas nem de longe menos importante, suas características naturais contam como condicionante e como um dos trunfos fundamentais a serem mobilizados, o que é particularmente importante no caso dos territórios rurais, e poderia, neste registro sociológico (não no econômico em sentido estrito), ser chamado de capital natural. 
A análise da realidade dos países do capitalismo avançado mostra que a emergência de uma nova ruralidade não é algo que se manifesta de maneira homogênea. A inserção das áreas rurais nas possibilidades abertas com esta nova etapa do desenvolvimento rural dependem, sobretudo, de características que lhe são específicas e que encontram sua melhor expressão na idéia de território, entendido como a trama complexa de aspectos ambientais, culturais, sociais e econômicos, cuja escala remete ao conceito de região e obriga a um seu reexame.

A abordagem territorial revela assim uma escala geográfica dos fenômenos relevantes e um conjunto de instâncias empíricas incontornáveis, cuja interpretação, contudo, demanda o suporte de uma sólida teoria social e ecológica capaz de lhe sustentar. Diferente, portanto, de uma mera construção identitária ou de um realidade cujas possibilidades estão previamente determinadas por sua configuração, os territórios podem ser vistos como um campo, no sentido dado por Pierre Bourdieu, como um todo estruturado de posições, cuja morfologia é dada pela distribuição desigual das diferentes formas de capital no seu interior, e cuja dinâmica obedece às lutas sociais pelas melhores posições no seu interior e, particularmente importante no caso de territórios rurais, aos constrangimentos e possibilidades oferecidos pelo meio natural.

Pouco se sabe sobre as condições que levam um território a encontrar o caminho da dinamização econômica com coesão social e conservação ambiental. Mas os resultados até aqui obtidos por vários programas de pesquisa levam a crer que aquelas configurações baseadas em formas mais diversificadas e desconcentradas de distribuição dos trunfos sociais e ambientais tendem a ensejar mais e melhores possibilidades de interação social em uma tal direção. 


\section{PARTE III}

\section{DESENVOLVIMENTO RURAL E MUDANÇA INSTITUCIONAL}




\section{Capítulo 4 - Os caminhos da disseminação da abordagem territorial}

As duas primeiras partes deste estudo se apoiaram em aspectos históricos e cognitivos para mostrar em que consistem os sentidos do desenvolvimento rural e o conhecimento que se tem de tais processos. A conclusão é que as teorias que procuravam inserir este desenvolvimento em leis gerais pecam sistematicamente por ignorar sua importância e prever seu declínio. E as razões disso são basicamente duas: determinismo excessivo e abstrato, de um lado, e ignorância quanto à importância dos fatores naturais de outro. Esta terceira parte se dedica agora à análise de um aspecto empírico do desenvolvimento rural da maior importância: o problema da mudança institucional ${ }^{80}$.

Não se trata de uma avaliação ou balanço das políticas desenhadas com tal intuito mas, antes, de uma crítica às dificuldades do Estado e das sociedades em operar com a mudança de paradigma contida na nova ruralidade, de maneira a sustentar a definição e a implementação das iniciativas propostas com esse fim.

Embora em diálogo com uma questão normativa, o viés da análise procura proceder a uma abordagem realista de tais processos. Sob o ângulo teórico, este capítulo pretende demonstrar aquilo que se poderia chamar de "embeddedness da dependência de caminho". Se Douglass North acertou ao descrever os mecanismos da permanência através do conceito de path dependence, sua explicação para a mudança revela-se demasiado frágil e limitada às fronteiras do individualismo metodológico. Por isso um segundo objetivo é fornecer uma espécie de crítica ou contra-exemplo ao esquema esboçado em seus trabalhos mais recentes (North, 2005). Ali ele tenta mostrar como a mudança institucional depende dos mecanismos de aprendizagem dos agentes sociais e de como isto se traduz em formas de conduta. Ou, em outros termos, como se formam e como agem as "estruturas mentais partilhadas". Embora North admita que as estruturas sociais funcionam como ambiente a este processo eminentemente cognitivo que é o aprendizado, em seu modelo explicativo as instâncias mobilizadas estão, por assim dizer, dentro dos muros do individualismo metodológico: trata-

\footnotetext{
${ }^{80}$ Algumas idéias e argumentos expostos nesta parte foram apresentados originalmente, na forma de artigo, no Congresso da Sociedade Brasileira de Sociologia, realizado em Belo Horizonte, em 2005. Cf. Favareto (2005b).
} 
se de explicar como estímulos e sanções se transformam em regras, e como regras transformam-se em formas de conduta. As próximas páginas pretendem mostrar o outro lado do muro: propriamente, como as instituições são elas mesmas expressões de conflitos e de compromissos, isto é, resultado das interações propiciadas por estruturas sociais determinadas $^{81}$. E, por último mas não menos importante, como estas estruturas não podem ser entendidas sem considerar o meio-ambiente. Trata-se, portanto, de não só abordar como os sistemas mentais partilhados influenciam a tomada de decisão dos agentes, e sim de como este conjunto de crenças e valores é socialmente formado.

Não há dúvida de que nos últimos dez ou quinze anos se erigiu um novo discurso sobre a ruralidade, em muito apoiado sobre os achados de estudos e pesquisas realizados nos quatro cantos do mundo ${ }^{82}$. Este novo discurso acabou progressivamente tomando a forma de consensos e orientações, não raramente amalgamados por agências internacionais de apoio à cooperação e ao desenvolvimento, fundos de financiamento e organismos multilaterais como a FAO - Organização das Nações Unidas para Agricultura e Alimentção -, o Banco Mundial, a Cepal - Comissão Econômica para a América Latina -, o BID Banco Interamericano de Desenvolvimento, o IICA - Instituto Interamericano de Cooperação Agrícola, a OCDE Organização para a Cooperação e o Desenvolvimento Econômico. Como se sabe, é enorme a influência destes organismos sobre a definição das políticas, sobretudo dos países da periferia e da semi-periferia do capitalismo mundial. O que se deve tanto ao papel de financiador de muitos desses organismos, como, talvez principalmente, pelo fato de funcionarem como uma espécie de pivô, através do qual gira uma articulação muito peculiar de interesses e competências envolvendo os campos acadêmico, político, econômico, em cuja dinâmica ocorre um movimento de legitimação recíproca entre os conhecimentos produzidos cientificamente, a definição de políticas no âmbito de países e governos locais, e a normatização dos procedimentos por estes organismos internacionais.

Por este motivo, a primeira das duas seções que juntas conformam esta parte do estudo é dedicada justamente a reconstruir e analisar a "nova visão" do desenvolvimento rural forjada no âmbito destes organismos. O interesse em tal movimento para os propósitos deste estudo é duplo: trata-se de pôr em evidência um núcleo comum presente nos diferentes discursos que

\footnotetext{
${ }^{81}$ Cf. é sugerido nos enfoques adotados por Pierson (2004) e Amable \& Palombarini (2005).

${ }^{82}$ Ver principalmente Capítulos 3.
} 
remetem a essa "nova visão"; e importa, igualmente, pôr em relevo omissões, impasses, disjunções existentes na passagem dos discursos científicos aos discursos normativos que se abrigam sob a "nova visão". Na seção seguinte a ênfase se desloca para as tentativas de levar à prática os elementos trazidos com a nova abordagem. Nesse momento, a unidade em análise é a experiência recente de países com problemas similares em passar da "nova visão à ação". Em particular, uma dimensão crucial dessa experiência é destacada: a situação que envolve as reformas introduzidas nas políticas e programas de países como o Brasil, a Argentina, o México, o Chile. Com este exercício, pretende-se interrogar as razões que respondem pelo êxito parcial destas inovações e, com isso, iluminar a natureza dos constrangimentos que pesam sobre as opções dos agentes públicos e privados em sua tentativa de promover o desenvolvimento dos territórios rurais.

A afirmação principal que sustenta esta parte do texto é que a "nova visão" do desenvolvimento rural se instituiu com força suficiente para reorientar o discurso e o desenho das políticas e programas formulados com este fim, mas isto não se fez acompanhado da criação de novas instituições capazes de sustentar este novo caminho. Ao contrário, o que parece estar ocorrendo é uma incorporação "por adição" dos novos temas onde, sob nova roupagem, velhos valores e práticas continuam a dar os parâmetros para a atuação dos agentes sociais, coletivos e individuais, estabelecendo aquilo que a literatura em economia institucional chama por dependência de percurso. Tornar esta assertiva palpável e interrogar as razões disto é, pois, o que se pretende com as próximas páginas.

\section{1 - O jogo e as regras}

Como mostra Navarro (2003), a idéia de desenvolvimento rural não é nova, mas houve, ao longo do tempo, um deslizamento no discurso político e acadêmico que é revelador das concepções orientadoras de tais propostas. Garcia (2002) vê, na América Latina, quatro grandes momentos. O primeiro marcado pelos projetos e iniciativas de desenvolvimento comunitário. O segundo, pelos grandes projetos de reforma agrária. $\mathrm{O}$ terceiro, por aquilo que se convencionou chamar de desenvolvimento rural integral. Até, por fim, o momento dos projetos que falam em desenvolvimento territorial e combate à pobreza. Um breve olhar 
sobre cada uma destas etapas ajuda a compreender as permanências e inovações introduzidas de período a período ${ }^{\mathbf{8 3}}$.

\subsection{1 - A “nova visão' do desenvolvimento rural}

Os projetos mais destacados e que poderiam ser qualificados como de apoio ao desenvolvimento comunitário remontam aos anos trinta, nos EUA e Índia. Desde 1945 esta denominação passa a frequentar os documentos oficiais das Nações Unidas e, em 1956, aparece como "a expressão para designar os processos em virtude dos quais os esforços de uma população se juntam aos de seu governo para melhorar as condições econômicas, sociais e culturais das comunidades, integrá-las a vida do país, e permitir-lhes contribuir plenamente ao progresso nacional" (ONU apud Garcia, p. 18). A partir dos anos 50, sob o patrocínio de agências como a Fundação Ford, várias experiências foram implementadas na África e Ásia, como resposta à Revolução Chinesa e à Guerra Fria. A idéia básica é que as comunidades possuem potencialidades que, com apoios pontuais, podem deslanchar. As principais estratégias, por sua vez, eram destinadas a satisfazer as necessidades básicas da população, propiciar maior participação, e apoiar a organização cooperativa. Elementos que, como se vê, ainda são muito presentes no discurso atual sobre desenvolvimento rural.

A partir dos anos 60 esta estratégia experimentou um descenso. As razões para isto são de fácil compreensão. Os projetos que vinham sendo implementados apresentavam uma enorme dependência de recursos externos, humanos e financeiros, tornando difícil sua ampliação e mesmo sua sustentação em longo prazo. Além disso, tais iniciativas revelaram-se frágeis no que diz respeito à necessidade de rápido aumento da renda e da produção nas comunidades atingidas. O caráter pontual e tópico dos investimentos realizados não contribuía para levar à dinamização desejada revelando-se meramente paliativos. Isto quando, pelo seu caráter restrito associado à introdução de elementos estranhos à tradição daqueles agricultores, os projetos apoiados não acabavam gerando atritos e conflitos nas próprias comunidades.

Nesta época, o pêndulo se desloca para a necessidade de mudanças estruturais. Na esteira dos movimentos revolucionários e de contestação que se espalhavam pela América Latina o tema da reforma agrária ganhou proeminência como principal política de desenvolvimento rural.

${ }^{83} \mathrm{O}$ item seguinte é fortemente apoiado em Garcia (2002). 
As origens do debate remontam à Revolução Mexicana de 1910, mas ganharam influência decisiva com a introdução de processos similares ocorridos na Ásia nos anos 40 (Turquia, Coréia, Japão, China, Taiwan). Em 1950 a ONU encomendou à FAO um estudo sobre a relação entre perfil fundiário e pobreza. $\mathrm{O}$ estudo indicava minifúndios com área insuficiente para reprodução social e a presença do latifúndio como marca da estrutura agrária da região. Paralelamente a Cepal apontava um lento crescimento da produção em relação a demanda nacional e internacional e a necessidade de um processo de modernização acompanhado de uma reforma agrária. Diagnóstico similar era produzido pelo Comitê Interamericano de Desenvolvimento Agrícola (CIDA), criado nos marcos da Aliança para o Progresso, de 1961. No início dos anos sessenta, sob o impacto destes estudos e de processos de reforma agrária levados adiante em Bolívia, México e Cuba, este era um tema fundamental em toda a América Latina, salvo na Argentina e Uruguai.

A experiência histórica demonstrou, no entanto, que as reformas eram parte de um projeto político para diminuir o peso dos latifundiários, mas não estava que tipo de propriedade deveria substituir o latifúndio. Esperava-se um impacto para além da produção agrícola, influindo nos níveis de renda e o conseqüente impacto sobre o mundo urbano e, principalmente, liquidar as relações não-capitalistas. A ausência de tecnologias apropriadas aos pequenos produtores, as dificuldades de acesso ao crédito e, enfim, todo o ambiente social e institucional desfavorável foram fatores que limitaram enormemente este intento.

Paralelamente às experiências de reforma agrária - ou de sua frustração como no caso brasileiro - ocorre uma rápida modernização do setor agrícola nestes países, com uma forte expansão da produção, aumento do comércio e uma urbanização rápida e crescente. Mas o efeito da chamada Revolução Verde para os pobres rurais foi nulo ou negativo. Uma das conseqüências foi a profunda heterogeneização destes espaços: alguns alcançam um modelo de integração competitiva enquanto outros aprofundam a situação de marginalização e decadência. Os organismos internacionais deram por fracassadas as políticas de reforma agrária. Como resultado, ocorre um realinhamento da estratégia de desenvolvimento, pondo ênfase em dispor aos pobres rurais todos os elementos que lhes permitiriam melhorar sua qualidade de vida e suas capacidades produtivas, o que incluía uma ampla gama de serviços sociais e serviços técnicos. Surgia a retórica do desenvolvimento rural integral. Entre 1948 e 
1960 o BM havia investido 6\% do financiamento total a programas rurais, cifra que passou a 24\% (Garcia, 2002). Mudanças similares ocorreram no BID. E no mesmo ano se cria o FIDA.

Apesar da ampliação dos recursos, um problema que persistiu nesta etapa foi a carência de recursos humanos para levar adiante tais programas. A solução encontrada foi priorizar pequenos proprietários com posse da terra. Esperava-se que seu efeito se irradiasse e beneficiasse os mais pobres. Mas o problema da posse da terra também era delicado. Em muitas áreas era mesmo uma condição para qualquer esforço de desenvolvimento. E, no entanto, ele nunca havia sido parte do rol de estratégias apoiadas. Nesta etapa, quando houve investimentos nesse sentido, priorizou-se a colonização e a regularização fundiária, e não a partilha de terras a fim de evitar conflitos. Vale lembrar que vários países da América Latina viviam sob regimes de exceção à época e a intocabilidade da propriedade fundiária era um dos pilares destes regimes. Além desta dificuldade operacional havia um problema institucional. $\mathrm{O}$ desafio era passar de projetos produtivistas para projetos integrados, mas isto trazia um problema de articulação, derivado da enorme pulverização de habilidades e competências em um número significativo de estruturas governamentais. Como forma de contornar esta limitação, muitas vezes se criou aparatos específicos, gerando paralelismos com a estrutura estatal. Outro problema estava no descompasso entre as exigências técnicas das agências internacionais e os recursos humanos locais. Formaram-se burocracias e desníveis salariais. Apesar do discurso, a participação dos pobres rurais não acontecia (Garcia, 2002).

O balanço geral até este período revela um quadro de difícil enfrentamento. As mudanças provocadas pela integração crescente de populações tradicionais aos circuitos de mercado trouxeram consigo uma crise das idéias mais tradicionais que orientavam as políticas voltadas para a economia camponesa. Além disso, as políticas já implementadas nas etapas anteriores não vinham apresentando impacto substantivo. A reforma agrária, a mais estrutural das tentativas ensejadas, chegou a alterar algumas estruturas, mas não alcançou a mudança preconizada. A desconexão entre políticas rurais e políticas macroeconômicas e a carência de recursos humanos revelaram-se fatores altamente limitantes para o êxito de qualquer política de desenvolvimento rural. 
A tônica dos anos 60 aos 80 foi justamente a ausência de políticas estruturais para o mundo rural, ficando suas possibilidades de melhoria restritas à adequação às políticas macroeconômicas e de incremento tecnológico ou aos programas pontuais apoiados por organismos internacionais, na maior parte das vezes em resposta a situações de efervescência social. No caso brasileiro, isto pôde ser percebido com a instituição de uma forte modernização tecnológica, uma crescente integração da atividade agrícola aos complexos agroindustriais, e a formação de um padrão corporativista de organização do agro onde cabia ao Estado, a um só tempo, o papel de indutor da economia e de repressor dos conflitos que daí emergiam.

A partir dos 80 vai ficando claro que, embora as economias tenham crescido e a produção de alimentos aumentado significativamente, houve um aumento da pobreza e da desigualdade. $\mathrm{O}$ tema do desenvolvimento rural como política específica volta à arena. Os organismos internacionais influenciam a agenda dos governos recolocando o tema em pauta, e o fazendo pelo registro da associação entre desenvolvimento rural, redução da pobreza e conservação dos recursos naturais. Mas este era também o momento onde a crise da dívida deu lugar a um processo de reestruturação econômica, o "ajuste estrutural", que levou a programas de modernização dos aparatos públicos, ordenamento das economias, busca do crescimento sustentado, abandono de políticas específicas de desenvolvimento.

Um dos eixos adotados foi justamente tomar a agricultura como uma saída produtiva, através do incremento e diversificação das exportações, da diminuição das importações, e da geração de saldo favorável para sanear as contas públicas e honrar compromissos externos. Este vetor obteve um razoável êxito nos seus intuitos fiscais e monetários imediatos, mas o impacto sobre a vida dos agricultores foi pequeno ou simplesmente negativo por uma série de motivos. O principal deles está no fato de que a renda das famílias rurais deixava progressivamente de vir do trabalho agrícola.

Já nos anos 90, outro eixo se constituiu com a adoção do enfoque territorial às políticas. Desde os anos noventa há uma série de programas de pesquisa e iniciativas de políticas como a criação da divisão territorial da OCDE em 1994. E em 1996 o Banco Mundial publica seu relatório "A nova visão do desenvolvimento rural", onde a marca é justamente uma tentativa de dar conta das mudanças porque havia passado o rural nas décadas anteriores e a 
necessidade que elas traziam em se passar de um enfoque setorial a um outro de caráter territorial, e, também, em se erigir um novo modelo institucional em torno destas políticas. Desde então foram vários os documentos nas diferentes agências multilaterais visando precisar o que seria esta "nova visão"

Estes vários documentos e as orientações neles contidas se apoiavam em alguns consensos sobre os problemas dos programas até aqui. Este consenso poderia ser sumarizado em seis pontos: a) falta de coordenação dos programas; b) descentralização da implementação mas com centralização das decisões; c) pouca adequação local em termos de tecnologia e de recursos humanos; d) concentração do crédito e distorções na política de subsídios; e) hipertrofia da presença estatal; f) custos das intervenções alto, reduzindo os efeitos dos investimentos diretos. As lições daí derivadas: a) a necessidade de priorizar um caráter multisetorial; b) a ênfase na forma de estruturar e institucionalizar a ação; c) importância de se reforçar a descentralização, a agilidade e a instituição de mecanismos de incentivos e controles, além de estudos sobre marco inicial dos projetos, a introdução de fase de preparação, e de instrumentos de monitoramento e avaliação; d) separar as ações sociais das setoriais e produtivas visando simplificar o desenho de programas; e) considerar áreas mias homogêneas o possível para implementar as ações; f) considerar os não-pobres, isto é, o território e as articulações que ele implica (Garcia, 2002).

Salvo lições polêmicas e de eficácia no mínimo duvidosa, como a separação entre iniciativas sociais e produtivas, ao que parece as recomendações dos órgãos e agências internacionais se coadunam com as tendências recentes do desenvolvimento rural e com os achados dos programas de pesquisa citados no capítulo anterior. Contudo, um exame mais detido da estrutura e do sentido destes documentos revela claramente dois tipos de impasse, ou dois dilemas: o primeiro é a permanência de uma visão agrária dos espaços rurais; o segundo, derivado do anterior, é o viés de política social subjacente às orientações.

Sobre a permanência da visão agrária, um olhar sobre alguns documentos destes organismos é bastante revelador. O relatório de 2001 do Banco Mundial (The World Bank, 2001-a) Plan de acción para el desarrollo rural em América Latina y el Caribe: um insumo para la

\footnotetext{
${ }^{84}$ Cf. The World Bank (2001-a, 2001-b), Cepal/FAO/Rimisp (2003), BID (2005). Ver também Echeverria (2001), Escobal (2002) Hopkins (2004).
} 
revisión de la visión a la acción - reafirma a estratégia de busca de inserção competitiva dos espaços rurais e destaca como um dos bloqueios a dificuldade de acesso a ativos fundamentais para tanto. Mas junto disso, destaca o peso que a agricultura deve continuar tendo no PIB. No rol de elementos a compor a estratégia aparece: a intensificação da agricultura entre pequenos, o melhoramento do acesso a terra e a serviços, as práticas de manejo sustentável, o fortalecimento do capital social. Elementos enfim que se combinam mais à velha visão do que a um caráter intersetorial do desenvolvimento rural. Este viés é reforçado no relatório de 2004, que tem o expressivo título - Beyond the city (The World Bank, 2005) -, mas no qual a principal ênfase recai sobre o efeito ampliado da agricultura na composição do PIB.

Da mesma forma o mais recente texto do BID - Perfil de politica de desarrollo rural (BID, 2005) - apresenta problemas similares. Deixando de lado a compreensível generalidade que envolve esse tipo de documento, com pretensões amplas resumidas em sete páginas, chama atenção a ausência de uma verdadeira "estratégia" a sustentar o conjunto de considerações e proposições nele contidas. Por certo há uma incorporação das dimensões territorial, institucional e ambiental, mas isso se dá mais "por adição" ao léxico dos formuladores das políticas ou, no limite, como identificação de instâncias a serem, de alguma maneira, envolvidas ou mobilizadas com as orientações enunciadas. O melhor exemplo disso está no fato de que a primeira menção explícita a uma estratégia territorial só aparece na última página, no item "Ejecución y cumplimiento"; e aparece como "enfoque de aplicação", não como "estratégia". Disso resulta uma disjunção importante: na "ejecución" tenta se aplicar um viés territorial, mas nas considerações, nos instrumentos e nas orientações enunciadas o viés é claramente produtivista e setorial. Seria possível citar exemplos em quase todas as partes do texto, sobretudo nos "objetivos". Da mesma forma o "problema institucional" aparece somente de maneira dispersa, com menções meramente pontuais.

Apesar da inovação discursiva, os documentos não expressam, portanto, uma interpretação dos problemas relevantes para a promoção do desenvolvimento dos espaços rurais e parecem não apreender os ensinamentos trazidos com a evolução recente dos estudos que vêm dando relevo à idéia de desenvolvimento territorial. A conseqüência é a proposição de diretrizes com alguma abertura para novas instituições, coerentes com esse novo quadro de referências, 
mas sem uma estratégia coerente a sustentá-la, sem mecanismos que possam favorecer sua criação.

Sobre a associação entre promoção do desenvolvimento rural e pobreza também há uma forte ambigüidade. É inegável que baixos indicadores econômicos e sociais são uma das marcas destes espaços. Dados da Cepal e da FAO apontavam para a existência de 65 milhões de pobres em 1970, 82 milhões no meio da década de 80, e 109 milhões em 2000. Com exceção do Chile, em todos os outros aumentou a pobreza no período. No entanto, este caráter que demanda estratégias específicas de discriminação positiva muitas vezes se traduz na introdução de um viés marcadamente assistencial a estas populações e a suas regiões, que tem o efeito não antecipado de excluí-las de todo um outro rol de programas e políticas. As políticas de dinamização econômica e fomento à inovação ficam reservadas àquelas que apresentam potencialidades competitivas. Às áreas rurais são direcionados os programas com recursos a fundo perdido e as estruturas governamentais com capacidades estabelecidas para o atendimento de populações em situações de precariedade social. Com isso, muitas vezes aprofunda-se a dicotomização que atribui ao rural somente o lugar do atraso e da pobreza.

Há duas razões para isso. A primeira é cognitiva: existe toda uma visão instaurada nos quadros mentais da burocracia governamental, mas também de pesquisadores e mesmo destas populações, onde estes lugares e suas associações já estão pré-estabelecidos. A segunda é política: estas populações não dispõem dos meios e dos recursos para pleitear outro tipo de investimento e de inserção governamental.

Como resultado, os investimentos produtivos são capturados pelos agentes mais tradicionais do agro reforçando sempre a mesma visão baseada na valorização dos recursos primários, mesmo na contramão das tendências em curso não só nos países do capitalismo avançado, mas também na América Latina. No Chile, 40\% das famílias já vive nas cidades e 53\% da renda provém de atividades não agrícolas. A diminuição da solidariedade e o aumento da individualização são traços crescentes nas áreas rurais. Mudanças migratórias têm mudado o perfil populacional de muitas áreas rurais com a chegada de profissionais liberais ou de retornados, agora com maior grau de escolaridade e dotados de novos vínculos extra-locais. 
$\mathrm{Na}$ prática, a associação entre ruralidade e pobreza traz uma contradição: os programas estabelecem um foco, um público prioritário - os pobres rurais, em geral famílias de agricultores - embora a abordagem se proclame territorial e, pois, multisetorial. Além destes impasses na formulação mesmo do discurso, cabe perguntar qual tem sido o resultado da tentativa de passar "da visão à ação".

\subsection{2 - Da visão à ação}

Um quadro geral das principais políticas e programas voltados para a promoção do desenvolvimento rural em países da América Latina no decorrer dos anos 90 deixa bastante claro o viés setorial destas iniciativas. A avaliação geral não é positiva quanto a seus êxitos, salvo no Chile, mas mesmo lá é difícil separar o que compete ao êxito dos projetos ou a própria trajetória de crescimento econômico experimentada ao longo dos últimos anos. Assim como no balanço das décadas anteriores, novamente se misturam aspectos operacionais com o lugar social das iniciativas. De um lado, influenciaram aspectos externos aos programas, como o enxugamento dos serviços públicos motivados pelas reformas estruturais ocorridas nesta década, ou a falta de diálogo entre instâncias econômicas e sociais ou entre diferentes níveis de governo. De outro, o amplo espectro de políticas e programas apresentavam baixa inovação e pouca complementaridade, como demonstra o quadro a seguir. 
QUADRO SÍNTESE DAS PRINCIPAIS

POLÍTICAS PARA O DESENVOLVIMENTO RURAL EM PAÍSES DA AMÉRICA LATINA

\begin{tabular}{|c|c|c|c|c|c|c|}
\hline País & Institucionalidade & Programas & Objetivos & Critérios/público & Principais ações & Obs. gerais \\
\hline Argentina & $\begin{array}{l}\begin{array}{l}\text { Programas e projetos são } \\
\text { subordinados à SAGPyA do } \\
\text { Ministério da Economia }\end{array} \\
\begin{array}{l}\text { Unidades de execução são criadas 'ad } \\
\text { hoc' para cada projeto }\end{array} \\
\text { Até } 1999 \text { prevalecem políticas } \\
\text { agrícolas ou por produto } \\
1^{\circ} \text { programa - PPNEA (Crédito e } \\
\text { apoio técnico para pequenos } \\
\text { produtores agropec. Do noroeste } \\
\text { argentino), de 1992-1997, com } \\
\text { financiamento do BID-FIDA } \\
\text { 1999 - Criação da Comissão de } \\
\text { Desenvolvimento Rural } \\
2001 \text { - 9 programas } \\
2004 \text { - Discussão sobre política de } \\
\text { desenvolvimento rural }\end{array}$ & $\begin{array}{l}\text { 1) Unidad de } \\
\text { minifúndio }\end{array}$ & $\begin{array}{l}\text { Apoio a agricultores } \\
\text { minifundistas } \\
\text { Tecnologia, organização, } \\
\text { capacitação para: a) fortalecer } \\
\text { capacidade de subsistência; b) } \\
\text { produção para mercados; c) } \\
\text { diversificação }\end{array}$ & $\begin{array}{l}\text { Minifundistas em zonas de } \\
\text { concentração fundiária, com } \\
\text { menos de } 2 \text { salários de } \\
\text { assalariado rural de renda, e } \\
\text { em situação de precariedade } \\
\text { social, econômica ou } \\
\text { ambiental }\end{array}$ & $\begin{array}{l}\text { Assistência técnica e } \\
\text { apoio organizacional }\end{array}$ & \\
\hline & & 2) $\begin{array}{l}\text { Programa Social } \\
\text { Agropecuário }\end{array}$ & $\begin{array}{l}\text { Aplicação no setor rural de } \\
\text { programa social do governo } \\
\text { (aplicado em diversas áreas). }\end{array}$ & $\begin{array}{l}\text { Assalariados e pequenos } \\
\text { produtores. No segundo caso, } \\
\text { exige-se a participação direta } \\
\text { no estabelecimento } \\
\text { agropecuário e empregando } \\
\text { mão-de-obra somente } \\
\text { ocasional. A renda do } \\
\text { estabelecimento não pode ser } \\
\text { superior ao salário de um } \\
\text { assalariado rural, nem podem } \\
\text { os ingressos externos serem } \\
\text { superiores a este valor. }\end{array}$ & $\begin{array}{l}\text { Assistência financiera, } \\
\text { técnica e apoio à } \\
\text { comercialização e à } \\
\text { atividades de } \\
\text { capacitação } \\
\text { A devolução dos } \\
\text { créditos integra um } \\
\text { fundo rotativo no } \\
\text { âmbito das províncias. }\end{array}$ & \\
\hline
\end{tabular}




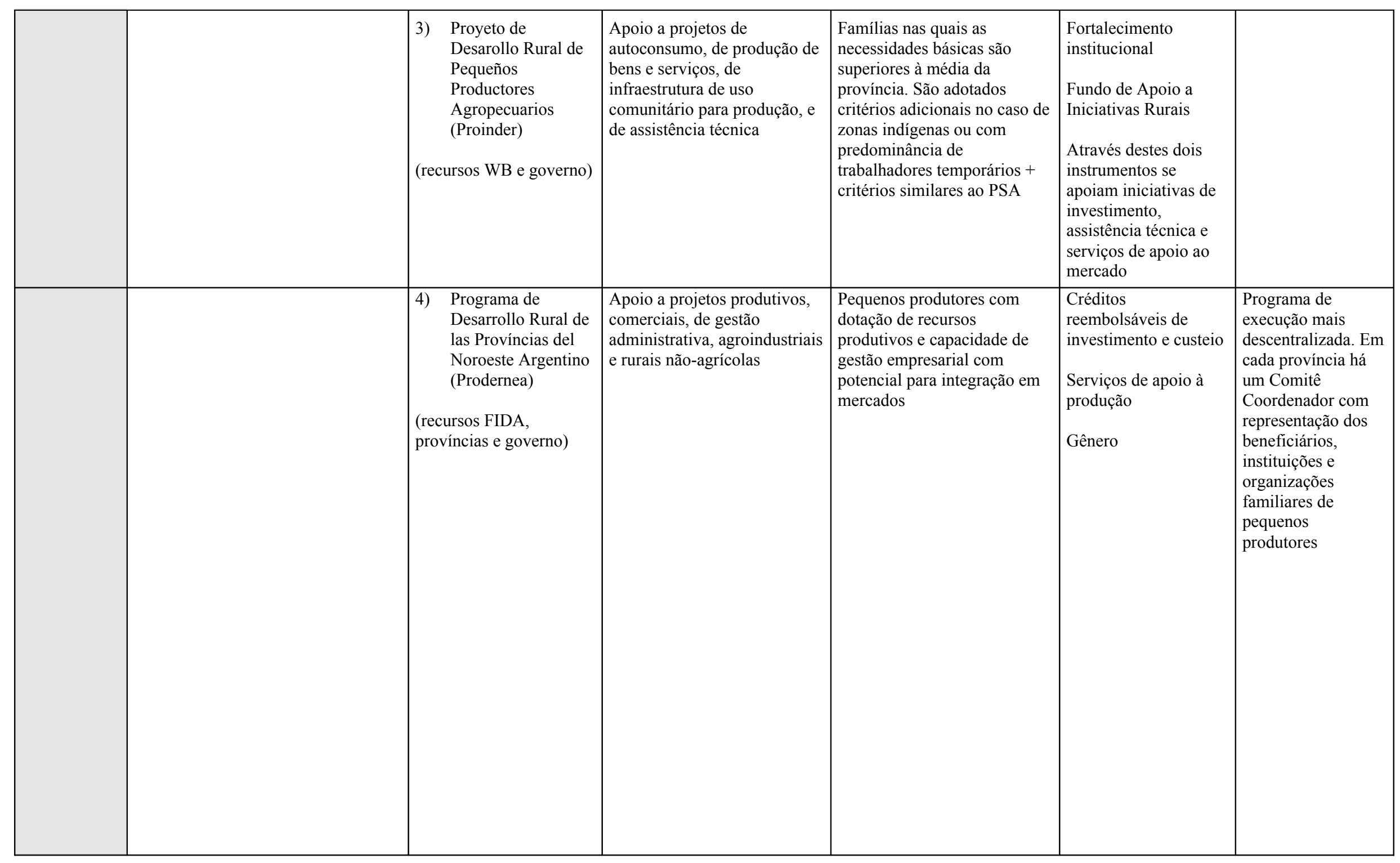




\begin{tabular}{|c|c|c|c|c|c|c|}
\hline Brasil & $\begin{array}{l}\text { Existem duas estruturas nacionais. } \\
\text { Ministério da Agricultura, orientado } \\
\text { ao fortalecimento da capacidade } \\
\text { competitiva da agricultura patronal. } \\
\text { Ministério do Desenvolvimento } \\
\text { Agrário, voltado a temas de } \\
\text { desenvolvimento rural sustentável e } \\
\text { reforma agrária. Outros programas } \\
\text { sociais ficam a cargo de ministérios } \\
\text { de outras áreas. }\end{array}$ & $\begin{array}{l}\text { 1) Programa Nacional de } \\
\text { Fortalecimento da } \\
\text { Agricultura Familiar } \\
\text { (Pronaf) }\end{array}$ & $\begin{array}{l}\text { Apoio técnico e financeiro } \\
\text { para o desenvolvimento rural } \\
\text { com base no fortalecimento da } \\
\text { agricultura familiar }\end{array}$ & $\begin{array}{l}\text { Agricultores familiares, com } \\
\text { prioridade para aqueles } \\
\text { situados nas categorias "em } \\
\text { transição" e "periféricos" (a } \\
\text { terceira categoria seria a dos } \\
\text { agricultores "consolidados"). } \\
\\
\text { São considerados agricultores } \\
\text { familiares aqueles que, sob } \\
\text { qualquer modalidade jurídica } \\
\text { de posse da terra, desde que } \\
\text { não tenham área superior a } \\
\text { quatro módulos fiscais } \\
\text { (unidade de medida), que } \\
\text { obtenham renda } \\
\text { predominantemente da } \\
\text { exploração do estabelecimento } \\
\text { agropecuário, que residam na } \\
\text { propriedade ou em } \\
\text { aglomerado urbano próximo, } \\
\text { contratação de mão-de-obra } \\
\text { eventual }\end{array}$ & \begin{tabular}{|l} 
Crédito de \\
financiamento e \\
custeio subsidiado e \\
reembolsável \\
Apoio à infraestrutura \\
(em convênio com \\
governos dos \\
municípios) através de \\
investimentos a fundo \\
perdido visando \\
melhorar a \\
infraestrutura e os \\
serviços de apoio ao \\
desenvolvimento rural \\
Capacitação para \\
disseminação de \\
conhecimentos e \\
tecnologias através das \\
empresas estatais de \\
assistência técnica e \\
extensão ou em \\
convênio com \\
organizações não \\
estatais
\end{tabular} & $\begin{array}{l}\text { Alto grau de } \\
\text { descentralização, } \\
\text { com base nos } \\
\text { CMDR e na } \\
\text { elaboração de } \\
\text { planos de } \\
\text { desenvolvimento } \\
\text { rural, inicialmente } \\
\text { em âmbito } \\
\text { municipal e, desde } \\
\text { 2002, em âmbito } \\
\text { intermunicipal }\end{array}$ \\
\hline
\end{tabular}




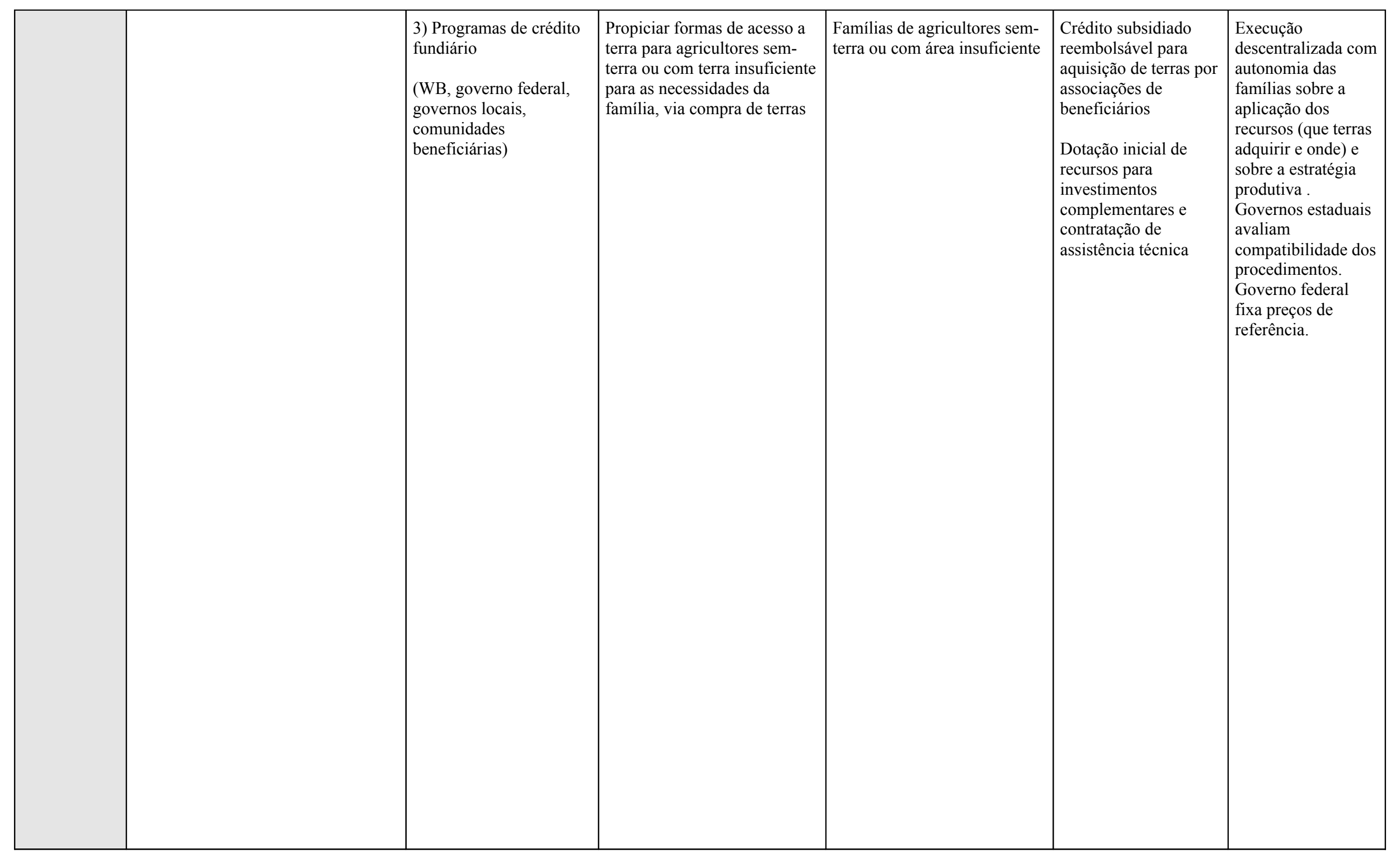




\begin{tabular}{|c|c|c|c|c|c|c|}
\hline \multirow[t]{3}{*}{ Chile } & $\begin{array}{l}\text { Não há uma órgão de Estado } \\
\text { encarregada de políticas de } \\
\text { desenvolvimento rural }\end{array}$ & 1) Prorural & $\begin{array}{l}\text { Melhorar as condições de vida } \\
\text { dos habitantes de zonas rurais } \\
\text { pobres, dinamizando as } \\
\text { economias locais com uma } \\
\text { visão territorial, multisetorial } \\
\text { e participativa }\end{array}$ & & $\begin{array}{l}\text { Execução e } \\
\text { coordenação de ações } \\
\text { de diversas agências, } \\
\text { serviços públicos e } \\
\text { agentes locais em } \\
\text { regiões prioritárias } \\
\text { Fortalecimento de } \\
\text { agentes locais através } \\
\text { da transferência de } \\
\text { capacidades e apoio } \\
\text { profissional } \\
\text { Ações múltiplas, } \\
\text { simultâneas e } \\
\text { complementares (em } \\
\text { diferentes setores } \\
\text { econômicos) }\end{array}$ & $\begin{array}{l}\text { Origem em 1997, } \\
\text { com aprovação } \\
\text { pelos ministros do } \\
\text { Comitê } \\
\text { Interministerial de } \\
\text { Políticas Sociais e } \\
\text { de } \\
\text { Desenvolvimento } \\
\text { Produtivo, visando } \\
\text { superar a } \\
\text { atomização e } \\
\text { insuficiêmncia da } \\
\text { ação pública através } \\
\text { da criação de uma } \\
\text { instituicionalidade e } \\
\text { de uma estratégia de } \\
\text { intervenção mais } \\
\text { apropriada e } \\
\text { baseada na } \\
\text { integração territorial } \\
\text { de programas }\end{array}$ \\
\hline & & $\begin{array}{l}\text { 2) Serviço de Asesoría } \\
\text { Local en Comunidades } \\
\text { Rurales Pobres } \\
\text { (Prodesal) }\end{array}$ & $\begin{array}{l}\text { Propiciar o acesso a serviços } \\
\text { de assessoria e apoio a } \\
\text { comunidades rurais pobres, } \\
\text { envolvendo aspectos } \\
\text { produtivos, ambientais e } \\
\text { organizacionais }\end{array}$ & $\begin{array}{l}\text { Comunidades rurais com } \\
\text { maior incidência de } \\
\text { indicadores de pobreza }\end{array}$ & $\begin{array}{l}\text { Embora os objetivos } \\
\text { envolvam múltiplas } \\
\text { dimensões, tem sido } \\
\text { dada ênfase ao } \\
\text { melhoramento da } \\
\text { produtividade }\end{array}$ & $\begin{array}{l}\text { Destacam-se o } \\
\text { caráter comunal e } \\
\text { os reduzidos } \\
\text { fundos, o que força } \\
\text { a articulação deste } \\
\text { programa com } \\
\text { outras iniciativas } \\
\end{array}$ \\
\hline & & \begin{tabular}{|l} 
3) Programa de \\
Desarrollo Productivo \\
Rural del Fondo de \\
Solidaridad Social (DPR- \\
Fosis)
\end{tabular} & $\begin{array}{l}\text { Fortalecer o desenvolvimento } \\
\text { produtivo de áreas rurais }\end{array}$ & & $\begin{array}{l}\text { Identificação } \\
\text { preliminar à execução } \\
\text { do projeto dos } \\
\text { beneficiários e do } \\
\text { capital social } \\
\text { disponível } \\
\\
\text { Apoio a atividades } \\
\text { prévias de } \\
\text { fortalecimento } \\
\text { organizacional (onde } \\
\text { necessário) }\end{array}$ & $\begin{array}{l}\text { Há a exigência de } \\
\text { que sejam aportados } \\
\text { recursos locais que } \\
\text { são } \\
\text { complementados } \\
\text { com investimentos } \\
\text { pelo programa, o } \\
\text { que favorece } \\
\text { interessantes } \\
\text { encadeamentos com } \\
\text { outros programas } \\
\text { ou com iniciativas } \\
\text { privadas e também } \\
\end{array}$ \\
\hline
\end{tabular}




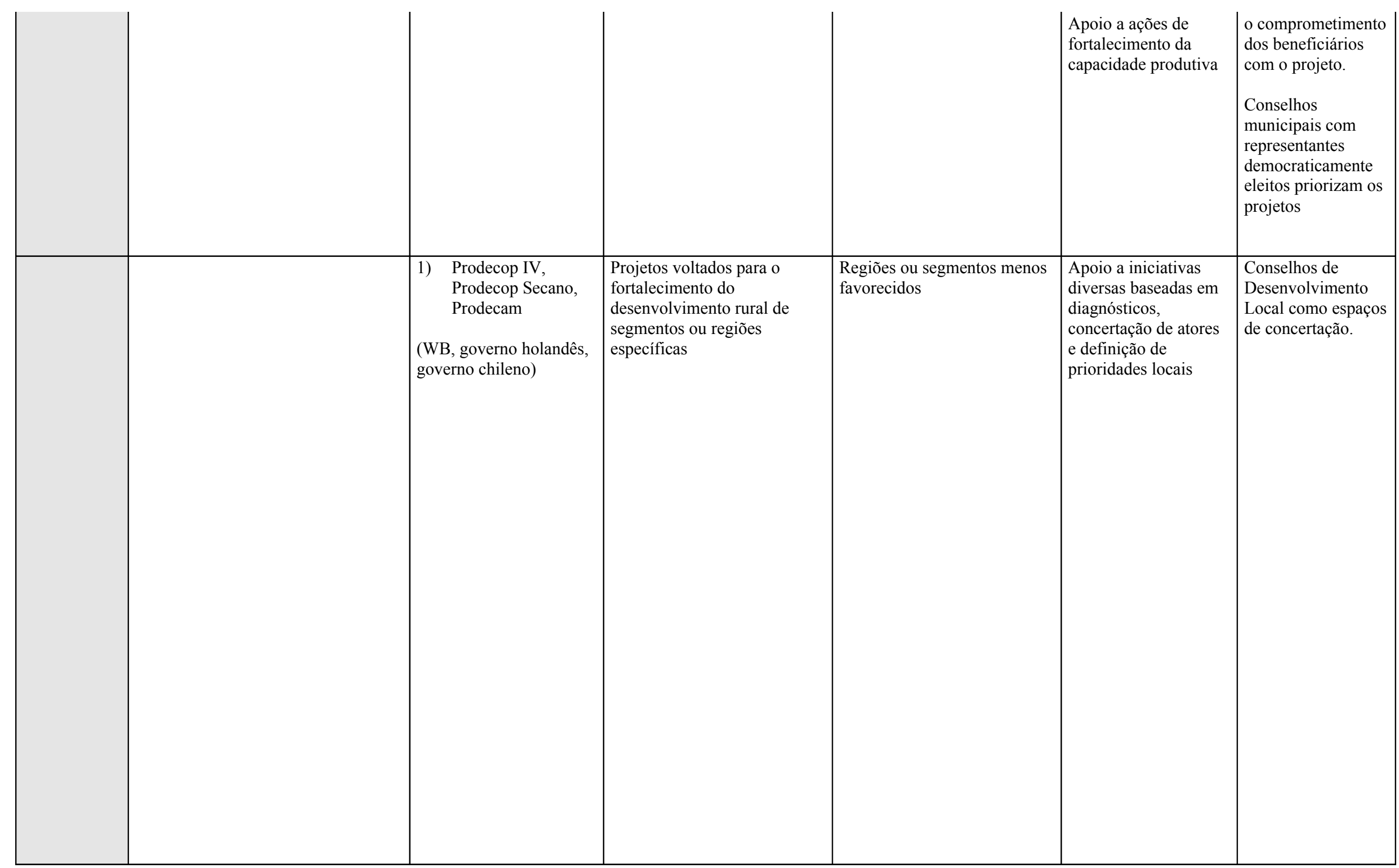


Influenciados pelas tendências das políticas nos países do capitalismo avançado e pelas descobertas de programas de pesquisa sobre a manifestação de processos sociais semelhantes também nos países da América Latina, vários países experimentaram a formulação ou o redesenho destas iniciativas em consonância com os marcos contidos na "nova visão" do desenvolvimento rural.

No caso brasileiro, o lugar institucional do principal programa de desenvolvimento rural - o Pronaf - sempre esteve vinculado às rubricas orçamentárias e aos fluxos da hierarquia administrativa federal relativos aos programas de combate à pobreza. Com isso, o Pronaf nunca foi alçado à categoria de política permanente, nem nunca dispôs de uma maior articulação com outras políticas estruturais do governo federal. As regras de acesso a algumas das linhas deste programa também são claros indicativos do foco no combate à pobreza. De 1996 a 2000 os municípios beneficiados com recursos do Pronaf/Infraestrutura - linha voltada para investimentos em infra-estrutura e serviços de apoio ao desenvolvimento rural - eram escolhidos tendo por base o baixo desempenho no Índice de Desenvolvimento Humano. A partir de 2001 o programa passa a apoiar projetos de caráter intermunicipal, agora escolhidos a partir de processo seletivo. Porém, na seleção dos projetos, pesa também o fato de se tratar ou não de projeto originário dos territórios considerados como prioritários pela Secretaria de Desenvolvimento Territorial do Ministério do Desenvolvimento Agrário, estes por sua vez, escolhidos a partir de uma combinação de critérios que envolvem a presença de agricultores familiares e assentados da reforma agrária e, novamente, a ocorrência de baixo IDH. Em nenhum dos dois períodos, portanto, os investimentos na agricultura familiar e no desenvolvimento rural estiveram articulados estrategicamente em ações voltadas para a diminuição de desigualdades ou para a dinamização das economias rurais, nem houve tentativa de superar a dicotomização ascendente-descendente que marca a orientação das políticas nas últimas décadas ${ }^{85}$.

Já no recente caso argentino as articulações entre pobreza, desigualdade e desenvolvimento são de outra ordem. O documento síntese apresentado no Taller Propuestas para el Desarrollo Rural y la Produccion Agropecuaria - realizado em 2004 com o objetivo de

\footnotetext{
${ }^{85}$ Cf. Abramovay \& Veiga (1998), Schneider, Mattei \& Cazella (2004), Favareto (2005-b).
} 
definir diretrizes para os temas anunciados no título do evento -, parte do questionável diagnóstico de que aquilo que caracteriza as áreas rurais é a fragilidade dos seus mercados locais. Disto decorre que a única possibilidade de seu desenvolvimento passa pela conexão a mercados dinâmicos, o que acontece através de inovações na produção local e da criação de instituições que permitam tanto estabelecer estas relações virtuosas com o espaço extralocal como fazer com que os ganhos daí advindos possam beneficiar os mais pobres. Embora aqui a dinamização das economias locais apareça como uma condição e um meio para o desenvolvimento destes territórios, a sua assimilação a situações marcadas pela pobreza e por mercados locais frágeis acaba pondo ênfase em demasia nas articulações extra-locais em detrimento da dimensão intra-territorial. Sem falar no problema da origem das instituições capazes de gerar dinamismo e de partilhar seus resultados ${ }^{86}$.

Se é verdade que certas regiões rurais poderão alcançar o caminho da dinamização através da especialização produtiva combinada à exploração de segmentos de mercado dinâmicos, também é preciso reconhecer que os casos explorados pela literatura disponível, em parte tratada nos capítulos anteriores, enfatizam não ser esta a tendência nos países do capitalismo avançado. A evolução e o estado recente desta mesma literatura sugere que, em primeiro lugar, o desenvolvimento dos territórios é o resultado de determinadas formas de coordenação capazes de fazer convergir os benefícios privados e sociais, seja nas formas de organizar a produção e a distribuição de bens individuais, seja nas formas de garantir que os rendimentos provenientes sejam revertidos de maneira a razoavelmente repartir os ganhos. Além disso, sugere também que as formações sociais marcadas por uma maior desconcentração da posse dos diferentes recursos - materiais, simbólicos e cognitivos - e de uma maior diversificação de seu tecido social são aquelas que mais favorecem a formação deste tipo de instituição, em oposição àquelas estruturas sociais mais especializadas, rígidas e concentradas. Esta é a vinculação do desenvolvimento às estruturas locais e às instituições que a concepção apoiada no trinômio pobreza, instituições, mercados externos não opera.

O que os exemplos brasileiro e argentino parecem demonstrar, no fundo, é que há uma associação nos quadros de referência de cientistas, da burocracia governamental, das elites,

\footnotetext{
${ }^{86}$ Esta concepção encontra-se sistematizada em Schejtman \& Berdegué (2003). Ver também a crítica de
} Schattan et al (2005). 
entre a idéia de que o desenvolvimento é um atributo do urbano e a decorrente associação do rural à pobreza. Numa espécie de versão da profecia que se cumpre por si mesma, esta visão influencia a formação de um campo de questões que se tornam legítimas ou ilegítimas ${ }^{87}$.

Esta dinâmica não é, contudo, autônoma. A crítica às origens agrárias como uma das raízes dos males das ex-colônias, a ideologia do progresso, a rápida industrialização de países como os aqui tomados como exemplo, a constituição de portadores destes diagnósticos e dos processos sociais que lhes consubstanciam são fatores que se combinaram para criar uma illusio, no sentido dado por Bourdieu (2001-b): uma adesão imediata à necessidade de um campo, no caso de vários campos, para os quais a idéia de urbanização crescente e irreversível é a doxa fundamental. Ela é, nas palavras do sociólogo francês, a condição induscutida da discussão, é aquela que, a título de crença fundamental, é posta ao abrigo da própria discussão. Sempre segundo Bourdieu, a illusio não é da ordem dos princípios explícitos, de teses que se debate e se defende, mas sim da ação, da rotina, das coisas que se fazem. Isto está na raiz do que North (1990) chama de path dependence : a dinâmica impulsionada pela existência de incentivos e constrangimentos que reforçam uma determinada direção para as ações de indivíduos e organismos sociais uma vez que ela tenha sido adotada. North, quando fala desta dependência de caminho sublinha, sobretudo, o papel que a aprendizagem gerada por dinâmicas de longo prazo tem no caráter incremental da mudança ou, inversamente, na manutenção desse sentido inicialmente dado. Bourdieu, de uma outra maneira, fala do mesmo processo social, mas reforçando a dinâmica conflitiva entre os agentes de um campo.

Em suma um dos principais dilemas da ação do estado nas suas tentativas de promover o desenvolvimento rural é esse lugar institucional da idéia de rural, de ruralidade, determinado tanto pela illusio no destino urbano do progresso social como pela dependência de caminho que ela gera nas ações de indivíduos e organizações. O caráter tido como residual do rural e sua associação automática à idéia de pobreza e de atraso

\footnotetext{
${ }^{87}$ A própria diminuição de prestígio da sociologia e da economia rural perante outros ramos destas disciplinas é um sintoma disso, a forma como estão organizados os recortes estatísticos de definição do rural um outro, e a evolução dos debates sobre desenvolvimento um terceiro.
} 
restringem de partida as possibilidades de investimentos científicos, políticos e econômicos, o que contribui para gerar um ciclo onde esta posição marginal é sempre reforçada, seja simbolicamente, seja materialmente.

Outra face do mesmo dilema envolve a tensão entre uma inércia institucional fundada em toda uma orientação para a lógica setorial dos investimentos e ações e o sentido territorial, portanto intersetorial e multidimensional, da "nova visão". Quem são os agentes de um e outro discurso e que interesses são mobilizados ou preteridos na ênfase a uma ou outra dentre estas orientações ? Novamente a experiência brasileira, mas agora também a mexicana, servem de exemplo.

No caso mexicano, a Câmara de Deputados e a Câmara de Senadores aprovaram uma Iniciativa de Lei de Desenvolvimento Rural (LDR) em 2000. No ano seguinte, a Iniciativa de Lei é vetada pelo Executivo Federal - o primeiro veto total nos últimos sessenta anos . As causas do veto presidencial foram basicamente três: uma concepção restrita ao agropecuário - de mais de duzentos artigos, a seção Fomento Agropecuário reunia cento e dzessete, ou 53\% do total; a atribuição das responsabilidades de sua aplicação à Secretaria de Agricultura, Ganaderia, Desevolvimento Rural, Pesca y Alimentacion (Sagarpa), mas sem a dotação dos instrumentos e recursos necessários; e o choque com outras leis especializadas, como a de associações agrícolas, de saúde animal e vegetal, águas e sementes (Del Toro, 2004).

Além destes argumentos, outros aspectos influenciaram a decisão do governo mexicano: a Lei previa a descentralização da participação mas centralizava a operacionalização dos programas e projetos, os recursos necessários para operá-la não estavam definidos, havia uma obrigatoriedade de organizações profissionais e econômicas participarem do Consejo Mexicano para el Desarrollo Rural (CMDR), além do conflito com compromissos assumidos pelo governo mexicano em acordos comerciais internacionais (Del Toro, 2004).

Em resposta ao veto presidencial, grupos parlamentares formularam a Lei de Desenvolvimento Rural Sustentável considerando as inconsistências e problemas que 
haviam levado à recusa da primeira Lei. Esta nova proposta foi submetida a um amplo processo de consulta pública ao longo de 2001, até ser aprovado por unanimidade pela Câmara dos Deputados e pela Câmara de Senadores, e posteriormente ser sancionada pelo Presidente da República no final do mesmo ano.

Somente o inédito veto presidencial à primeira versão da Lei e as razões que o fundamentaram já são, por si, um indicativo mais do que suficiente do viés setorial dos formuladores de políticas e dos grupos e interesses que influenciam em sua moldagem. Mas os contornos do arranjo institucional previsto na Lei reforçam ainda mais essa leitura. Primeiro, a Lei estabelece um papel de destaque para o CMDR, com a coordenação de diversos serviços e programas, muitos deles dispersos por várias secretarias. No entanto, ele próprio, o CMDR, é uma estrutura subordinada a um ministério de claro recorte setorial: a Sagarpa. Além disso, o enfoque dos seis serviços criados com o Artigo 22 da Lei, e os 12 Programas através dos quais eles são operacionalizados, deixam claro o enfoque territorial e, novamente, a primazia do destaque ao combate à pobreza na definição de suas linhas estratégicas.

No caso brasileiro, o conjunto de políticas que precisariam estar combinadas para promoção do desenvolvimento rural está disperso por, pelo menos, meia dúzia de estruturas ministeriais diferentes: os Ministérios da Agricultura, do Desenvolvimento Agrário, da Integração Nacional, da Educação, da Saúde, do Meio-Ambiente. Os ministérios da Agricultura e do Desenvolvimento Agrário, aqueles mais diretamente reportados ao espaço rural, têm como seus principais programas, iniciativas de caráter eminentemente setorial, respectivamente as políticas para o agronegócio e para a agricultura familiar. O Ministério do Desenvolvimento Agrário tem também sob sua responsabilidade um recém criado Programa Territorial (Pronat), originário do desmembramento da linha infra-estrutura e serviços do Pronaf, ao passo que a principal política territorial do governo federal se encontra na alçada do Ministério da Integração Nacional e seu programa voltado para as mesorregiões. 
E a confusão aumenta quando se olha para o interior do Ministério do Desenvolvimento Agrário, que tem por missão a promoção do desenvolvimento rural: estudos apontavam desde o início da existência do Pronaf o crescente distanciamento entre as ações de investimento nos territórios, através da vertente infra-estrutura, e as ações de crédito e investimento setoriais, na agricultura. Com a criação da Secretaria de Desenvolvimento Territorial em 2003 e, mais recentemente, com o desmembramento da linha infra-estrutura do Pronaf, dando origem ao Pronat, este distanciamento só cresceu: não há nenhuma forma de colaboração e de complementaridade entre os diferentes programas prevista no atual planejamento das secretarias que compõem o ministério e que são por eles responsáveis (Favareto, 2005-b) ${ }^{88}$.

Igualmente sintomático é o processo que envolveu a elaboração da Proposta de Plano Nacional de Desenvolvimento Rural Sustentável entre 2001 e 2002 até a aprovação pelo Conselho Nacional de Desenvolvimento Rural Sustentável da versão final no mesmo ano: embora a versão inicial apontasse para uma estratégia fortemente baseada em uma visão territorial do desenvolvimento rural, a Conferência Nacional que estava marcada para debatê-la e aprová-la foi cancelada; após várias negociações com setores de governo e movimentos sociais o próprio CNDRS aprovou uma versão menos ousada, que no entanto, também foi deixada de lado com a nova gestão à frente do Executivo Federal após 2003.

Os dois exemplos mostram como a inércia institucional, apoiada em interesses e em sistemas cognitivos afinados com a lógica setorial cristalizados nos agentes sociais, se não bloqueiam no mínimo limitam fortemente a operacionalização de uma visão de desenvolvimento de caráter territorial ${ }^{89}$. Além da illusio, que assimila o rural ao atraso e à produção de bens primários e da dependência de caminho que ela gera, dificultando a mudança institucional, contribui o fato de que, em uma e em outra visão, o tipo de agentes e

\footnotetext{
${ }^{88}$ Uma tentativa de integração começou a ser esboçada em 2005 e tem como principal instrumento os chamados Planos Safra Territoriais. Trata-se de uma tentativa de integrar políticas no âmbito de um território. Mas, sintomaticamente, trata-se, mais uma vez, da integração das políticas de apoio à agricultura, agora em escala intermunicipal.

${ }^{89}$ A noção de "bloqueio" foi utilizada por Nazareth Wanderley em seus estudos para falar da especificidade que cerca as possibilidades de reprodução social das famílias de agricultores em situações como a brasileira. Com diferenças, a mesma idéia é aqui aplicada para falar do lugar social das políticas de desenvolvimento de territórios rurais.
} 
as possibilidades de articulação de seus interesses são sensivelmente diferentes. A lógica do território incorpora o espaço consumível, mas também o espaço imobilizado em componentes não monetarizáveis. Por decorrência, o enfoque territorial implica em lidar com aspectos não diretamente mercantis a influenciar as regras para a apropriação ou regulação do uso social destes espaços. Além disso, no território os agentes são múltiplos e, sobretudo, difusos, enquanto no enfoque setorial eles são facilmente identificáveis e seus interesses menos dispersos.

Como se vê, apesar da forte espacialidade que marca o rural, as regras do jogo continuam fortemente orientadas pelo viés setorial, na formulação das políticas, e na mobilização dos atores. Embora o discurso sobre desenvolvimento territorial tenha entrado definitivamente para o discurso acadêmico e governamental na presente década, até o momento trata-se de uma incorporação "por adição" dos novos temas, sem a devida mudança institucional capaz de sustentar a inovação que ela deveria significar.

\section{O problema das instituições}

Que instituições importam, eis um slogan do qual poucos ainda divergem. Os dois dilemas brevemente apresentados nas páginas anteriores bem o demonstram. Num aparente paradoxo, é curioso observar como várias vertentes das teorias institucionalistas estão presentes na formulação da "nova visão" do desenvolvimento rural pelos organismos internacionais. E, no entanto, a principal falha na implementação da "nova visão" via políticas e programas governamentais esbarra, justamente, na dificuldade da mudança institucional.

No já citado documento do Banco Mundial editado por Serageldin \& Steeds (1997), as menções às reformas institucionais existem, mas elas são por demais genéricas e ocupam um lugar claramente secundário no rol de recomendações veiculadas. No documento elaborado por Escobal (2001) para a FAO, toda a ênfase recai sobre instituições, mas ali há uma visão restrita, onde história e conflitos não têm lugar, onde a dinâmica que incide sobre a criação ou a mudança institucional não é tratada. 
O problema que envolve mudança institucional repousa principalmente nas instituições informais e nos conflitos entre instituições e organizações, com bem demonstra a obra se North (1990). Isso fica claro ao analisar não só as dificuldades da mudança nos países da América Latina tomados, por exemplo, nesta terceira parte do estudo, mas também na explicação das diferenças entre o recorte recente das políticas para o desenvolvimento rural na Europa e nos Estados Unidos, apontada na segunda parte.

Mas esta explicação ainda não é suficiente. Ainda é preciso fazer frente à crítica de Przeworsky (2003), segundo quem a explicação institucional afirma que instituições são importantes, mas não mostra como elas são criadas e qual é a dinâmica que responde por esta importância. Para superar esse dilema, é preciso inscrever instituições numa teoria social. Para além da determinação pela evolução dos custos de transação, certamente importante para a performance econômica de que trata North, o desempenho do desenvolvimento de determinadas sociedades e territórios, no sentido mais amplo que os melhores usos do termo sugerem, remete a outros conceitos que permitam lidar com uma idéia de agente, de sujeito, em cujas escolhas pese não somente o balanço racional de custos, mas também outras ordens de constrangimentos.

Conceitos úteis são, portanto, justamente aqueles que vão remeter às estruturas sociais. Os agentes da inércia ou da mudança institucional são motivados por interesses, e para fazê-los prevalecer jogam com recursos acumulados em diferentes esferas da vida social numa luta incessante. A mudança pode, assim, ocorrer tanto como decorrência de longo processo incremental como pode, a depender do êxito nas estratégias dos agentes nestas lutas pela imposição de seus interesses, ser motivada por rupturas ou transições mais aceleradas.

A mesma idéia vale para a escala dos territórios e, nesse âmbito, a criação de instituições mais favoráveis à dinamização dos territórios e à diminuição das desigualdades parece ser fortemente influenciável por determinadas características da morfologia social local. Isto é, é mais fácil encontrar portadores de novas instituições em formações sociais que estão em afinidades eletivas com elas (Weber, 1998). Tecidos sociais marcados por uma maior 
desconcentração e descentralização da posse das diferentes formas de capital (social, humano, econômico, simbólico), para usar os termos de Bourdieu, tendem a ser ambientes mais propícios ao engendramento de formas mais dinâmicas de interação, facilitando o aprendizado coletivo e a cooperação que estão na base da formação de novas instituições.

Para os contornos das políticas para o desenvolvimento rural ao menos duas lições derivam do que foi aqui exposto. Primeiro, o estímulo a formas descentralizadas de produção e à diversificação das economias locais mostra-se claramente desejável para criar ambientes e instituições que possam favorecer a ampliação das possibilidades dos indivíduos e a diminuição dos constrangimentos negativos sobre suas escolhas. Segundo, mudança institucional pode até ser induzida, mas somente através de mecanismos cuja repercussão só se manifesta em termos de médio e longo prazo, seja pela via do aprendizado, seja pela via do acúmulo e conversão de recursos mobilizados na direção da mudança. São afirmações que sugerem o quão distante as instituições para o desenvolvimento rural ainda estão do intento muitas vezes desejado de promover a dinamização econômica com promoção da coesão social e através de formas responsáveis de uso social dos recursos naturais.

\section{2 - Um novo compromisso institucional ?}

O objetivo deste capítulo consiste em analisar as dificuldades dos Estados e governos locais em operar com a "nova visão" do desenvolvimento rural surgida da evolução, nas últimas três décadas, de estudos e orientações de políticas. Através de exemplos da trajetória recente das políticas de países como Brasil, México, Argentina e Chile, foi possível ver como estas iniciativas têm esbarrado em dois dilemas fundamentais. O primeiro representado pela ênfase no combate à pobreza e suas implicações tanto para a identificação dos territórios alvo dos investimentos como para os tipos de complementaridades a serem buscadas com outros programas e políticas. O segundo diz respeito à tensão presente no caráter territorial das novas orientações em contraposição ao viés setorial das instituições existentes. Na raiz de ambos, viu-se como a illusio (Bourdieu, 2001-b), ou as formas de racionalização predominantes (Weber, 1998), associam o rural à 
pobreza e à imagem do lugar destinado a realizar a produção de bens primários, impulsionando a um determinado sentido no encaminhamento dos esforços visado o desenvolvimento rural, o que North definiu como dependência de caminho (1990).

Apesar das inovações introduzidas, o resultado desta dificuldade em promover mudanças institucionais compatíveis com a "nova visão" do desenvolvimento rural corrobora a afirmação de North (1990) de que é mais fácil promover mudanças nas regras formais do que nas regras informais que regem uma sociedade ou grupo social, sobretudo porque as segundas são mais difusas e formadas através da sedimentação de vários processos sociais, em uma escala de tempo que muitas vezes envolve gerações.

Se a dinâmica pela qual as instituições são criadas ainda é pouco conhecida, o que as teorias disponíveis insinuam ou atestam pode ser resumido nas três afirmativas a seguir: primeiro, a principal forma da mudança é a evolução incremental pelo aprendizado; segundo, a mudança pode também ser alcançada pela alteração das posições e do peso social dos agentes portadores das novas e das velhas instituições; terceiro, mudança pode ainda ser induzida por alterações nos sistemas de incentivos e constrangimentos. A primeira destas formas é a mais comum, mas também a menos direcionável. A segunda é aquela que se materializa em eventos e momentos de ruptura, tão importantes quanto raros. A terceira é aquela preconizada pelas políticas públicas. Todas as três revelam que a introdução do adjetivo territorial no repertório das organizações não-governamentais, da burocracia estatal e dos movimentos sociais é marcada pelos limites de uma incorporação "por adição", como foi aqui sublinhado, e não como um sinal de mudança institucional. 
Nos países da América Latina a emergência da abordagem territorial está ligada a processos históricos que em muito se assemelham, apesar de diferenças de extensão e de intensidade, a fenômenos vistos nos países do capitalismo avançado - como a mudança na composição setorial das economias locais ou da renda das famílias de agricultores, como as novas dinâmicas populacionais. Não se trata, portanto, de um debate europeu meramente transplantado para os países da periferia, em que pese as diferenças nas assimetrias entre populações rurais e urbanas e nas características dos compromissos institucionais. Mesmo assim é inegável que o caminho pelo qual esta abordagem foi introduzida só pode ser compreendido quando se faz sua gênese, dos primeiros estudos nos anos setenta até a tentativa de sua implementação como projeto normativo na presente década. Neste movimento, fica claro como a disseminação da retórica do desenvolvimento territorial é resultado das injunções entre as esferas da economia, das ciências, e da política, num jogo de mútua legitimação, através do qual se pode compreender o tipo de interesses sociais que balizam os rumos deste debate, e onde as agência multilaterais ocupam um lugar de destaque, justamente por permitir estas interpenetrações entre as várias esferas e por funcionar como uma espécie de legitimador de abordagens ascendentes.

A dinâmica que envolve estas intersecções revela toda uma estrutura de bases cognitivas e interesses traduzidos em incentivos e constrangimentos estabelecidos em consonância com os aspectos mais marcantes da velha visão. Como resultado, a passagem do compromisso setorial ao territorial nas instituições e políticas para o desenvolvimento rural torna-se incompleto, uma espécie de "inovação por adição" no vocabulário, no discurso e nas políticas, de órgãos governamentais e de agentes sociais como organizações e apoio e movimentos sociais, sem, ainda, um correspondente em termos de mudança institucional. 


\section{PARTE IV}

\section{A RACIONALIZAÇÃO DA VIDA RURAL}




\section{Capítulo 5 - A racionalização da vida rural}

Entre o ditado medieval que dizia "o ar das cidades torna as pessoas livres" (Weber, 1998), até a recente constatação de que para a maior parte dos europeus, hoje, "os campos são mais associados à liberdade do que as cidades" (Hervieu \& Viard, 1996), certamente algo acontece. As partes anteriores deste texto devem ter deixado claro que as mudanças por que passou o desenvolvimento dos territórios rurais, mais intensamente nos últimos trinta anos, representam o início de um novo momento em sua longa evolução. Se a longa transição para o capitalismo trouxe consigo o "fim da tirania da distância e da agricultura", nos termos de que falava Paul Bairoch (1992), os tempos atuais parecem completar aquele longo movimento e iniciar uma nova ancoragem da ruralidade. As Partes I e II apoiaram-se em aspectos históricos e cogntivos para demonstrar em quê consiste o conhecimento que se tem sobre desenvolvimento rural. Foi possível ver como os processos sociais contemporâneos integram o urbano e o rural, em vez de opô-los inconciliavelmente, como bem o demonstram as mudanças demográficas em curso - com a atração ao universo rural de classes médias, aposentados, profissionais liberais -, as transformações econômicas com o aumento das rendas não-agrícolas, a diversificação das economias rurais -, e com as inovações institucionais - com a regulação crescente do rural por sua importância como paisagem e como fonte de recursos naturais. A Parte III, por sua vez, abordou uma dimensão empírica da maior importância - o tema da mudança institucional. Foi possível ver, ali, como o novo momento da evolução da ruralidade ainda não encontra correspondente em um novo compromisso institucional, não mais baseado no viés setorial de definição do que é o rural, mas sim territorial. Nesta parte, agora, trata-se de remontar aos aspectos teóricos, com o principal intuito de delinear uma abordagem condizente com o conteúdo social do rural contemporâneo. Se o paradigma fundado numa visão agrária do mundo rural perde poder explicativo, que tipo de abordagem pode revelar uma maior aderência aos contornos do real, tal como exposto nas partes anteriores?

Deixando de lado os autores e abordagens que não conferem estatuto explicativo ao rural, talvez não seja equivocado dizer que a literatura contemporânea tem destacado três 
implicações teóricas fundamentais que emergem com a nova ruralidade. Primeiro, trata-se efetivamente de um novo momento. Isto é, muda a qualidade das instâncias empíricas fundamentais definidoras do rural e as formas de articulação entre elas. E aí, o traço marcante é o deslizamento do caráter estruturante dos processos agrários para processos intersetoriais e regionais, ou em outros termos, territoriais. Um deslocamento que tem, na sua base, um novo enraizamento ambiental da ruralidade, com repercussões para a economia destes territórios, para o perfil demográfico e a estratificação social local, e para as instituições que regulam o uso dos recursos naturais e o comportamento dos agentes. Esta é uma dimensão que tem sido muito sublinhada nos trabalhos de Marcel Jollivet (1998) e que é muito bem equacionada nos recentes artigos de José Eli da Veiga (2004, 2005). Segundo, este traço marcante da nova ruralidade não é, obviamente, um processo homogêneo. Não é preciso ir muito longe para encontrar realidades onde os conflitos agrários, no seu sentido mais tradicional, se mostram presentes. E muitas vezes de maneira cruel. Este caráter multifacetado, onde formas de integração a mercados dinâmicos, novas práticas sociais e novas formas de uso dos espaços rurais coexistem com situações de forte estagnação econômica e degradação social, coloca a ênfase nas múltiplas possibilidades de construção da ruralidade, numa composição de identidades e conflitos potencialmente bastante diversa e cujo sentido dependerá sempre das heranças políticas e culturas e das formas de inserção na economia e na sociedade envolvente. Com nuances, este viés está presente em autores como Marsden (1998, 1999), Mormont (2000), Jean (1997) e em toda uma literatura discutida com muita propriedade particularmente em Wanderley (2000). Terceiro traço a destacar, tanto esta nova direção dos fenômenos rurais como sua manifestação desigual e heterogênea só podem ser compreendidos a contento através de uma abordagem que refira tais processos a agentes concretos, a práticas sociais que tem por portadores sujeitos sociais. Uma necessidade que contrasta com a tendência claramente dominante em abordar os processos de desenvolvimento exclusivamente sob o viés normativo que o debate comporta. Na literatura européia esta é uma preocupação presente nos estudos de Ray (2000, 2002), por exemplo, e tem sido crescentemente enfatizada nos trabalhos recentes de Abramovay (2005-b). 
Cada uma destas três dimensões aqui sumariamente destacadas pode, por certo, ser objeto de aprofundamentos e aplicações. Ainda que nos limites aqui impostos, foi isto o que se procurou fazer nas partes anteriores: mostrar uma direção emergente para os processos de desenvolvimento rural e situada na sua longa evolução histórica, demonstrar algo sobre sua heterogeneidade e as razões disto, sublinhar o embeddedness da dependência de percurso e da mudança institucional. O próximo passo, agora, consiste em apresentar uma idéia que permita, como corolário, abordar os diferentes aspectos a que cada uma destas dimensões faz referência. O que se pretende demonstrar, e isto é obviamente uma idéia de clara inspiração weberiana, é que um traço marcante da ruralidade contemporânea é este crescente processo de desencantamento e racionalização da vida rural. $\mathrm{O}$ argumento central a ser exposto ao longo das próximas páginas é que esta idéia, além de permitir que se ponha em relevo um aspecto da maior importância e, no entanto, pouco enfatizado na literatura sobre o tema, representa também um dépassement do paradigma clássico de explicação do desenvolvimento rural e que tem por fundamento básico uma visão eminentemente agrária e tradicional.

A primeira seção é dedicada a uma reflexão sobre teoria social e desenvolvimento rural. À luz de tudo o que foi exposto nas partes anteriores, pretende-se estabelecer um diálogo com os aspectos mais usualmente invocados nas teorias sociais para explicar fenômenos de desenvolvimento rural. O objetivo é mostrar os descolamentos entre alguns dos pressupostos presentes naquelas teorias, ou em interpretações e desdobramentos ulteriores, e as mudanças que se fizeram sentir de maneira mais acentuada nos últimos trinta ou quarenta anos e que foram discutidas nos capítulos anteriores. A segunda seção, num movimento em certa medida inverso, destaca a validade daquele outro elemento explicativo fornecido pelas teorias clássicas: a crescente racionalização que passa a orientar tanto a conduta ético-cotidiana do conjunto de seus agentes como a moldagem das instituições informais e formais que regulam as relações sociais típicas destes espaços.

Trata-se, em síntese, de propor uma abordagem que permita uma tripla aderência à nova condição do objeto ao qual ela é aqui direcionada. Ela tem uma aderência histórica, já que o processo de racionalização, como ensina Weber, representa um trajetória de muito longa 
duração, tal como a própria evolução da ruralidade. Ela tem uma aderência morfológica, à medida que as formas de ação racional comportam não só uma racionalidade instrumental, derivada da adequação entre meios e fins, e que em geral informa as concepções vulgares da questão, mas envolve também formas de racionalidade substantiva, isto é, referidas a valores. Distinção que será importante para compreender a diversidade de situações presentes nas diferentes manifestações da ruralidade no mundo contemporâneo e nas diferentes maneiras de grupos sociais distintos se posicionarem no interior de cada uma delas. E, por fim, ela tem uma aderência conceitual, por estar ancorada numa robusta teoria social que lhe dá suporte e que é fornecida pelo pensamento do grande sociólogo alemão.

\section{1 - Crítica à visão agrária dos territórios rurais}

O estudo da relação entre as cidades e os campos já estava presente desde antes da institucionalização das ciências sociais e de seus ramos de conhecimento ${ }^{90}$. Mas as bases fundadoras das abordagens que viriam a se consolidar nas ciências sociais, também neste terreno, encontram-se melhor sistematizadas em dois de seus grandes clássicos: Marx e Weber. Abramovay (1992) começa seu livro destacando justamente ser impossível encontrar uma questão agrária formulada explicitamente na obra de Karl Marx. É verdade que há várias passagens de seus mais importantes textos dedicadas às condições políticas do campesinato - como em O Dezoito Brumário de Luís Bonaparte -, ou às particularidades que envolvem a renda da terra - como em $O$ Capital e nas Teorias da Mais-Valia. E que em certos trechos de Formações Econômicas Pré-Capitalistas ou em A ideologia alemã o tema da relação entre as cidades e os campos aparece, embora tratado nos quadros da divisão social e espacial do trabalho típica da emergência do capitalismo. Mas não será possível encontrar nos escritos do pensador alemão conceitos e articulações teóricas que permitam dar conta nem da especificidade que cerca a produção familiar e o

\footnotetext{
${ }^{90}$ No século XIX, é justamente sobre a relação entre estes dois pólos, tendo a realidade russa por objeto, que Storch elabora sua Theory of Civilization: enquanto cidades são identificadas como centros de cultura em termos de empreendedorismo, aprendizagem, conhecimento tecnológico, a chave do desenvolvimento consiste em trazer os campos para próximo das cidades, utilizando para isso os caminhos naturais como os rios (Backaus \& Meijer, 2001), num reflexo claro de uma situação onde a necessidade de integração entre os espaços se faz presente, ao mesmo tempo em que os ventos da época trazem claramente os signos da industrialização e da urbanização crescente, como se viu no tópico anterior.
} 
lugar que ela vai ocupar no desenvolvimento capitalista, nem das manifestações espaciais diferenciadas do desenvolvimento rural.

Tanto o já citado Abramovay, como também Malagodi (1993) e Hegedus (1986), entre outros, procuram mostrar em seus trabalhos como o campesinato e a questão agrária não ocupam um "lugar", propriamente falando, no esquema teórico de Marx. Mais que isso, destacam que há uma espécie de impossibilidade lógica em compreender ontológica e epistemologicamente esta forma social de produção dentro de seus quadros cognitivos. Isto porque a oposição capital-trabalho adquiria um estatuto fundante na oposição que dá base à dialética do desenvolvimento capitalista, a qual, com seu caráter progressivo e envolvente acabaria por subsumir todas as outras formas, tidas como pretéritas. Esta dinâmica e os problemas lógicos e teóricos que ela traz são tratados com clareza e propriedade por estes autores, e por isso foge aos propósitos destas linhas reproduzi-la. Basta destacar que, não obstante esta ausência, ou este lugar meramente subsidiário nos esquemas teóricos marxianos, toda uma retórica e um amplo repertório de escritos científicos e políticos foram construídos em torno da especificidade do desenvolvimento capitalista na agricultura e às articulações econômicas e de classe a que ela dá origem ${ }^{91}$.

Uma primeira vertente se constituiu a partir da obra de dois importantes teóricos marxistas: Lenin e Kautsky. Do primeiro, destacam-se, sob o tema que aqui mais interessa, os livros $O$ Programa da Social-Democracia, e principalmente $O$ desenvolvimento do capitalismo na Rússia. Do segundo, seu mais famoso texto: A questão agrária. Em Kaustky, sua ênfase vai no sentido de demonstrar como, com o progresso das forças produtivas, os pequenos estabelecimentos não teriam como incorporar as inovações tecnológicas, organizacionais e econômicas em igualdade de condições com a produção capitalista. Como decorrência, a

${ }^{91}$ A conhecida passagem de Teorias da Mais-Valia é totalmente auto-explicativa a respeito: “...o desenvolvimento econômico distribui funções entre diferentes pessoas; e o artesão ou o camponês que produz com seus próprios meios de produção ou será transformado gradualmente num pequeno capitalista que também explora o trabalho alheio ou sofrerá a perda de seus meios de produção e será transformado em trabalhador assalariado". Se há alguma exceção na obra de Marx quanto a um tratamento específico da questão camponesa, ela está no texto conjunto com Engels, A questão camponesa na França e na Alemanha. Mas também ali trata-se mais de um texto político do que de uma análise detida da situação histórico-concreta deste grupo social em cada um dos dois países. A leitura do texto deixa clara a derivação das conclusões sobre as possibilidades futuras dos camponeses do sistema lógico erigido em torno da oposição capital-trabalho. Cf. Abramovay (1992). 
integração com a indústria estaria reservada aos capitalistas, restando aos camponeses a subordinação crescente, até a inviabilidade de sua reprodução social. Já em Lênin, há uma tentativa em classificar a heterogeneidade dos segmentos de agricultores de sua época.

Mas estas diferenças serviam, sobretudo, para divisar a porção de estabelecimentos que poderia evoluir em direção ao pólo capitalista daqueles que deveriam crescentemente passar a viver em condições que os aproximaria mais e mais do proletariado, inicialmente através de uma cada vez maior dependência da venda de sua mão-de-obra, ainda que preservando a posse da terra, e definitivamente através da perda completa da autonomia e sua total redução à condição de proprietário exclusivamente de sua força de trabalho. Estas idéias se materializaram nos conceitos de "diferenciação social", em Lênin, e de “industrialização da agricultura”, em Kautsky.

O que é comum a ambos é esta idéia geral de que a agricultura e o mundo rural devem ser vistos como parte do desenvolvimento capitalista. Parte da fragilidade destas teses está no fato de que elas tinham mais a ver com os embates políticos e os dilemas que precisavam ser teoricamente equacionados à época do que, propriamente, com análises econômicas e sociológicas. E na análise econômica, prevalece uma ênfase econômica e setorial. Outro problema está nos limites históricos mesmo destas teorias. O que nem estes autores nem seu maior inspirador, Karl Marx, poderiam prever, é que a realidade dos países do capitalismo avançado, sem falar, portanto, nas formações periféricas, iria apresentar um grande desmentido histórico às suas teses. As formas familiares de produção não só negaram a inevitabilidade de sua mera transformação em proletariado com firmaram-se mesmo como a forma predominante na maior parte dos principais países capitalistas ${ }^{92}$.

A plena integração da agricultura à indústria não trouxe consigo a artificialização de todas as etapas do processo produtivo nem mostrou qualquer inaptidão das formas familiares à incorporação do progresso técnico. Embora se trate das formas sociais de produção, tais concepções tiveram repercussão para as manifestações espaciais do desenvolvimento

${ }_{92}$ Abramovay (1993) relata exemplos históricos nos EUA, Inglaterra e na Comunidade Européia. A explicação das razões históricas do porque isto se deu desta maneira é o objeto central do livro de Veiga (1992). 
capitalista. Se há, nos clássicos, esta impossibilidade em compreender a especificidade destas formas que viriam a se tornar as predominantes, obviamente as articulações destas formas em termos de processos territoriais também não poderiam estar presentes. Todas as análises daí derivadas pecam ou por exagerar no caráter envolvente das dinâmicas emanadas do universo industrial e urbano, como locus privilegiado das trocas e da localização das empresas dos setores secundário e terciário, ou por analisar o rural como espaço dotado de características próprias, mas cuja lógica é sempre reativa ou dependente ao pólo dominante. Nas ciências sociais, esta perspectiva assumiu, sobretudo, a forma das várias teorias baseadas em uma espécie de continuum entre o urbano e o rural. Nesta idéia, menos do que uma diferença substantiva há um prolongamento, incompleto, parcial, arrefecido, do urbano e do industrial sobre o rural, o agrícola, o agrário. Assim como em relação ao campesinato, a marca do rural em uma tal abordagem é justamente seu "não lugar".

Uma segunda vertente é formada por aqueles estudos que procuraram justamente partir desta lacuna e construir um modelo explicativo fundado na especificidade das formas camponesas e dos traços distintivos da ruralidade. Sobre uma economia camponesa, os principais nomes são sem dúvida Alexander Chayanov e Jerzy Tepicht. O tipo de questão que estes autores se colocaram era diferente daquilo que havia motivado as teorias de Lênin e Kautstky porque era diferente o contexto de suas obras. Chayanov e Tepicht deparavamse já com a necessidade de interpretar as condições de permanência do campesinato sob o desenvolvimento das forças produtivas e não apesar delas ou contra elas. Da mesma forma nos vários escritos das teorias que tratam das sociedades camponesas, o que está em jogo é explicar um sistema de oposições sociais onde este personagem ocupa papel de destaque, complexificando, portanto, a polarização entre operários e capitalistas.

Se nos desdobramentos da primeira vertente têm origem as teorias do continuum, neste caso a afirmação da especificidade vai influenciar a origem de várias teorias que passarão a enfatizar o aspecto da dicotomia entre o rural e o urbano. Mesmo assim, também aqui a história se encarregou de solapar as bases de tais edifícios teóricos. Primeiro, abalando as 
condições da autonomia camponesa, tão bem retratada em Abramovay (1992). Segundo, e como que por extensão, implodindo os alicerces da sociedade agrária.

Já em Weber, a parte de sua teoria geralmente invocada para tratar da análise do fenômeno da urbanização é aquela dedicada à questão da sociabilidade. E, de fato, em seu pensamento há um sentido geral no movimento do real que pode ser expresso pelas idéias de "racionalização do mundo" e "autonomização das esferas". O problema aqui é o uso mesmo da noção de sociabilidade para falar de um movimento geral, envolvente ao conjunto da sociedade. A complexidade pode ser mensurada pelo fato de que a elucidativa introdução de Gabriel Cohn à edição brasileira de Economia e Sociedade, intitulada Alguns problemas conceituais e de tradução em Economia e Sociedade, adverte que o termo "sociedade" - gesellschaft - não ocupa lugar central na terminologia weberiana, onde costuma ser substituído por uma expressão que designa mais propriamente as relações interindividuais constitutivas da sociedade do que esta rede de relações já dada. Esta expressão sim - vergesellschaftung - poderia ser traduzida por socialização, mas esta solução foi abandonada na tradução brasileira porque poderia induzir a interpretações equivocadas de certas passagens e também porque convinha realçar o aspecto de relação e, portanto, de ação social típica da análise weberiana. A solução encontrada foi adotar o termo "relação associativa", num intuito de sublinhar que não há qualquer sentido prédeterminado na ação social dos indivíduos, em sua socialização, e sim que ela se dá em bases muito específicas e permeadas pelas circunstâncias sociais imediatas, pelo sentido social atribuído pelos próprios indivíduos em sua ação (Weber, 1998).

A coisa fica mais nebulosa quando se descobre que há um par para a Vergesellschaftung de Weber, a Vergemeinschaftung - relação comunitária. Sob novos termos, reproduz-se, outra vez, a oposição comunidade-sociedade. Mas isto, e parece ser este o ponto enfatizado pela solução adotada por Cohn, não apaga o fato de que, em Weber, apesar do movimento geral do real em direção à maior racionalização, o sentido da ação é sempre dado na percepção e representação dos agentes, embora não se esgote nela por ser mediada pelas circunstâncias imediatas. 
Não se trata então nem de antepor uma objetividade externa à ação social dos agentes, nem de restringir a explicação aos termos da interação entre eles, mas de entender a trama na qual ela se compõe, onde as idéias canalizam interesses moldando o sentido da ação social. É nesse sentido também que o resgate da tipologia das cidades abre uma brecha para pensar diferentes tipos de cidades e, pois, diferentes relações com os campos que a envolvem. Os critérios adotados para a definição das cidades, em Weber, abrem assim margem para duas abordagens: a oposição gemenschaft-gesellschaft, mas também a abordagem relacional. Claro que a que viria por se instituir foi a oposição comunidade-sociedade, tanto mais que a sociologia rural nasce com a pressão por compreender os fenômenos relacionados à desestruturação de comunidades rurais pelo avanço do processo de industrialização e de desenvolvimento capitalista (Martins, 1986).

A oposição comunidade-sociedade tem na verdade uma origem anterior, em Tonnies, que formaliza uma idéia de rural com características próprias, derivadas da condição de isolamento ${ }^{93}$ : as situações correlatas à condição de ruralidade serão identificadas no interconhecimento, coesão, continuidade, emotividade e tradição; e ao urbano, inversamente, irão corresponder situações como a impessoalidade, a mobilidade, o racionalismo, a inovação. Daí, em parte, o diálogo natural que se estabeleceu entre a sociologia rural e a antropologia, e não com a economia ou a geografia. Uma concepção que se institucionaliza posteriormente com o texto clássico de Sorokin ${ }^{94}$.

Já na abordagem do continuum, onde a oposição entre os dois pólos vai ser substituída por uma gradação que, a rigor, se mostra uma forma diferente da mesma dicotomia: um pólo será tomado como ativo, como dominante, e o outro como passivo, como aquele sobre o qual agem os processos sociais emanados do outro extremo, aos quais só cabe a adaptação ou a reação.

\footnotetext{
${ }^{93}$ É bom lembrar que, no caso do pensamento de Tonnies, o problema mais sério diz respeito às aplicações que foram feitas a partir dele. Neste autor, a oposição comunidade-sociedade, embora estruturada a partir de critérios polarizadores, dá origem a uma tipologia, cuja lógica teórica é muito próxima do recurso weberiano dos tipos ideais.

${ }^{94}$ Cf. Sorokin, Zimmerman \& Galpin (1986).
} 
É assim que as décadas de 20 e 30 são palco da institucionalização dos estudos rurais como ramo específico da sociologia e, os anos que se seguiram, dos desdobramentos das perspectivas inicialmente adotadas. Para o caso dos Estados Unidos, tanto quanto da França, por exemplo, o primeiro momento foi fortemente marcado pela adesão aos marcos gerais da sociologia clássica, com definições claramente apoiadas na perspectiva dicotômica. Posteriormente, no caso da sociologia americana as análises passam a sofrer a influência decisiva do ambiente vivido com o auge da modernização agrícola, numa tendência que viria a se consolidar posteriormente na chamada sociologia da agricultura, onde o rural perde importância para a agricultura e a estrutura agrária (Friedland, 1982). Na França, por sua vez, as perspectivas marcadas pela influência dos clássicos vão sendo seguidas por abordagens que, também influenciadas pelas mudanças no ambiente do pósguerra, irão passar a tomar para análise as contradições entre a chamada "sociedade camponesa" ${ }^{95}$ e os efeitos da modernização, até desembocar, nos anos 70 , na temática que envolvia a chamada "urbanização dos campos" "96.

Esta evolução, no entanto, não deve deixar a impressão de que, desde os clássicos, há um movimento linear e sem nuances de submissão e profecia quanto ao fim do rural ou quanto à irremediável subordinação histórica do rural ao urbano. Se em sociologia isto não chega a ser límpido e cristalino, na historiografia francesa e na história econômica alemã é possível encontrar nomes como Braudel, Schmoller, Ropke, que sempre estiveram enfatizando as interdependências entre os dois espaços. Nestes autores, a interdependência surge não da análise das causas do desenvolvimento, talvez com exceção de Braudel, e sim da identificação dos efeitos deletérios deste sobre as cidades, como a proletarização, e a necessidade de encontrar caminhos para amenizá-la. A possibilidade anunciada nestes autores reside nas diferentes modalidades possíveis de integração dos campos. Nestes casos trata-se de algo um tanto próximo da tradicional visão do continuum, mas com uma pitada de antevisão do que aconteceria a partir do Pós-guerra, com o papel reservado às unidades familiares e àquilo que alguns chamaram por interiorização do desenvolvimento.

\footnotetext{
${ }^{95}$ Cf. Mendras (1976)

${ }^{96}$ Ver principalmente o volume especial da Études Rurales organizado por Georges Duby, em 1973.
} 
Este amplo e rico conjunto de obras infelizmente ficou minorado pelas repercussões de outros como Lefebvre, que, inversamente, preferiu ver no movimento do real o completo triunfo da urbanização. Segundo o filósofo e sociólogo francês, originalmente um pesquisador dedicado aos estudos rurais, a passagem para o último quarto do século passado havia representado a emergência da sociedade urbana, a sucessora da sociedade industrial: a Revolução Urbana. Por Revolução Urbana Lefebvre (1970/2002) compreendia o conjunto de transformações que a sociedade contemporânea atravessava para passar do período em que predominaram as questões relativas ao crescimento e industrialização para outro onde a problemática urbana prevaleceria decisivamente, um período em que a busca das modalidades próprias à sociedade urbana passaria ao primeiro plano ${ }^{97}$.

O que muda em termos de instâncias empíricas e de articulação conceitual nas teorias sobre desenvolvimento com a "nova ruralidade", da qual a abordagem territorial é uma das mais profícuas expressões ? Deve ter ficado claro que os contornos da ruralidade no capitalismo contemporâneo ainda não encontraram um padrão claro e com relativo grau de homogeneidade, tal como no período que vai do pós-guerra até a crise do produtivismo. Os parâmetros desta situação é determinada por quatro ordens de fatores: a) as metamorfoses por que passam os espaços rurais, com uma uniformização entre os mercados de bens econômicos e simbólicos característicos dos universos rural e urbano e os processos sociais a isso subjacentes (encurtamento das distâncias entre rural e urbano, amenidades rurais como objeto de consumo urbano, acesso a equipamentos outrora típicos do urbano às populações situadas nas áreas rurais, etc); b) as mudanças no padrão de regulação que incide sobre as áreas rurais, o que envolve a reforma das políticas agrícolas, de um lado, a crescente regulação dos fatores ambientais, de outro, e a tentativa de encontrar novos equilíbrios entre as atribuições e instrumentos de regulação entre diferentes níveis geográficos; c) as novas dinâmicas demográficas e econômicas dos espaços rurais, com destaque para a multiplicidade de agentes que fazem esta nova ruralidade e a igual diversificação e diferenciação das atividades produtivas nos espaços rurais; d) a crescente valorização das amenidades rurais como principal vantagem comparativa destes territórios.

\footnotetext{
${ }^{97}$ Para uma crítica mais detida ao pensamento de Lefebvre sobre o triunfo da civilização urbana, ver Veiga (2004). Este debate foi resumidamente reproduzido no Capítulo 2 desta tese.
} 
A breve reflexão feita nesta seção serve principalmente para mostrar que, nas raízes clássicas da teoria social, as possibilidades de compreensão dos fenômenos rurais se consolidaram, destacadamente, a partir de dois registros. Um, de viés econômico, onde as estruturas determinantes do desenvolvimento rural estão assentadas nos caracteres agrários destas sociedades. E outro, de viés cultural, no qual a tradição e a oposição comunidadesociedade é que adquirem estatuto fundante em tais processos. Como foi demonstrado nos capítulos anteriores, as bases sociais destes dois pilares foram solapadas com as mudanças introduzidas na vida rural nas últimas décadas, esvaziando seu conteúdo explicativo. Mas, e isto é fundamental sublinhar, esta crítica à visão agrária dos territórios rurais não significa uma rejeição dos clássicos para explicar os fenômenos relativos ao rural, e sim a um paradigma que encontrou nestes pressupostos uma determinada base cognitiva. O pensamento de Marx e Weber pode, sim, a partir de outros elementos contidos em suas teorias, instrumentalizar uma análise do desenvolvimento rural. Numa perspectiva marxista, é possível valer-se dos recursos da dialética para explicar, a partir do estudo de casos concretos, as injunções, conflitos e complementaridades entre o rural e o urbano. Numa perspectiva weberiana, a idéia de racionalização, absolutamente central em sua obra, pode, igualmente, fornecer uma poderosa e inovadora abordagem. É isso o que se pretende esboçar na próxima seção.

\section{2 - A racionalização da vida rural}

Antes de mais nada, e para evitar interpretações errôneas, é preciso compreender exatamente o que o conceito de racionalização significa. Em geral a idéia de racionalização sugere uma lógica instrumental, de mera adequação entre meios e objetivos. No entanto, a tipologia de Weber é bem mais complexa. Segundo ele, a ação social pode ser: a) racional com relação a fins, quando é determinada por expectativas quanto ao comportamento de outros homens ou objetos do mundo exterior e quando tais expectativas funcionam como condições para o alcance de fins racionalmente avaliados e perseguidos; b) racional com relação a valores, quando motivada pela crença consciente no valor, seja ele ético, estético, religioso ou outro próprio de uma certa conduta, independente de êxito; c) afetiva - quando especialmente emotiva, fundada em afetos e sentimentos; d) tradicional - quando 
determinada por um costume arraigado (Weber, 1988). No mesmo texto ele destaca ainda que só muito raramente a ação social está orientada exclusivamente por um destes tipos (grifo de Weber). Longe de tratar-se de uma classificação exaustiva, trata-se sim de tipos puros, construídos com fins de pesquisa, os quais servem como referência de análise, para se saber o quão próxima ou distante a realidade em estudo deles se encontra.

Não há impossibilidade lógica - ao contrário, há probabilidade real -, de que os tipos apareçam juntos e combinados. Nada impede, portanto, que a ação social de indivíduos ou grupos sociais seja motivada, a um só tempo, por uma ação racional com relação a fins e com relação a valores ou até mesmo com a tradição. Mas, da mesma forma, nada impede também que um destes tipos seja predominante. Este é o ponto que aqui se quer destacar, que a racionalização avança por todos os domínios da vida rural, em geral vista sob o signo oposto, como lugar da tradição em oposição à modernidade geralmente representada pelo mundo urbano.

O momento atual representa, na verdade, a etapa mais recente de um longo processo de desencantamento e racionalização que tem início nos tempos mais remotos da vida em sociedade. Pierucci (2003) refaz toda a trajetória do conceito de desencantamento em Weber e sublinha os marcos fundamentais. Não cabe aqui repeti-lo. Para os nossos propósitos, cabe apenas destacar as correspondências entre a evolução dos espaços rurais e este processo de desencantamento e racionalização ${ }^{98}$.

Até a Revolução do Neolítico e a formação dos primeiros assentamentos humanos não se pode falar em distinção cidade e campo e, nesse momento, o encantamento da vida cotidiana é quase total. O advento da agricultura permitiu a introdução de uma primeira ruptura, representada pela possibilidade de manipulação da natureza, do mundo, do encantado, em um outro grau que o nomadismo, e a maior sujeição às condições naturais que lhe é inerente, antes não permitia. Desloca-se com isso, e progressivamente, a

\footnotetext{
${ }^{98}$ Esta periodização do longo processo de desencantamento e racionalização da vida rural, expresso nos três parágrafos a seguir sintetiza elementos fornecidos por algumas obras fundamentais sobre racionalização, vida rural e relações entre a sociedade e natureza. Cf., principalmente, Pierucci (2003), Bairoch (1992), Ponting (1995), Thomas (2001).
} 
possibilidade dos homens sobre sua condição de estar no mundo com correspondentes impactos no sentido da ação social dos indivíduos.

A longa etapa na evolução da ruralidade, que vai do nascimento do fenômeno urbano até a industrialização, e que Bairoch designou como um período marcado pela "tirania da distância e da agricultura", comporta, na verdade, um lento movimento de racionalização, que pode ser desdobrado esquematicamente em alguns passos. A profecia do judaísmo antigo, que vetava qualquer forma de adoração e meios mágicos, associada ao o pensamento helênico, estabelece uma nova e ainda mais profunda ruptura, constituindo-se uma espécie de ponto inaugural do desencantamento do mundo e, como correspondência, de eticização e moralização da vida social. A relação com o mundo natural aprofunda aquela inversão em relação aos primórdios e iniciada já na etapa anterior - de um animal entre outros o homem passa a se ver como aquele ser diferenciado que recebe a terra do Deus pai para nela crescer, povoar e fazer frutificar. O mundo é visto como criação de Deus, morada do homem. Enquanto tal, é, a um só tempo, submetida aos desígnios humanos, porque este é filho do senhor do universo e nesta condição ela lhe foi dada, mas é também sagrada porque concebida por este deus e seu mais valioso presente. Não é mais mágica, porque o poder não emana mais das coisas, como os espíritos das florestas. Com o advento do Iluminismo completa-se a mudança de comportamento em relação à natureza. Mais e mais ela é vista e tomada como esfera a ser dominada e posta a serviço da condição humana, com tudo aquilo que a técnica e o desencantamento do mundo, em lugar do mágico e do sagrado, permitem.

A posterior associação entre ciência e processo produtivo completa o longo movimento. No plano das idéias seu correspondente aparece na associação entre a racionalidade com relação a fins, que permitia o equacionamento de interesses materiais dos homens, a uma racionalidade com relação a valores, na qual os interesses ideais de salvação são com ela conciliados através da ética compatível com o "espírito" do capitalismo. Assim como as cidades foram as portadoras das idéias religiosas que desencantaram o mundo antigo e medieval, elas são, até aqui, o lugar por excelência no qual tais idéias e interesses podem estar em afinidades eletivas. 
A nova etapa do desenvolvimento rural, tal como qualificada nesta tese e em outros trabalhos, e típica das décadas mais recentes, comporta também um novo momento neste longo processo de racionalização da vida rural. São três os seus traços mais marcantes. No que diz respeito às formas de condução da vida cotidiana, completa-se a extensão da racionalização para todos os domínios da vida rural, sobrepondo-se não só às formas encantadas de relação com a natureza, mas, até mesmo, à tradição, no caso das relações associativas. No que diz respeito à relação entre sociedade e natureza, não ocorre nem uma intensificação da oposição levada aos limites na etapa anterior, nem um reencantamento do mundo natural ou retradicionalização. Acontece, antes, o contrário, a busca por uma diminuição da assimetria entre sociedade e meio-ambiente, cuja melhor expressão se encontra na crescente valorização das amenidades naturais e nas tentativas de contenção dos problemas ambientais globais. E, por fim, quanto à relação rural-urbano, deixa de ser prerrogativa das cidades e do urbano estar em afinidades eletivas com as possibilidades de se fazer da vida uma vida crescentemente conduzida.

Este novo conteúdo da racionalização da vida rural no mundo contemporâneo tem suas bases, no plano material, na ascendência de interesses compatíveis com ações de conservação ambiental, seja pelas perdas geradas com o desgaste de recursos naturais que afetam tantas empresas, países e regiões, seja pela introdução de especialidades econômicas e intelectuais relativas a tais esforços ou ao aproveitamento destas amenidades naturais como negócio ou como conforto material. No plano dos interesses ideais, a motivação vem da tentativa de combinar à ocidentalização e tudo o que ela implica os pressupostos éticos presentes na retórica do desenvolvimento sustentável e que não lhe são nada naturais: a conservação da natureza, a coesão social e melhoria das possibilidades materiais das pessoas, a possibilidade de reencontro com o passado e com a natureza que o rural muitas vezes propicia.

Dito desta forma o processo de racionalização deixa ver sua face mais positiva. Mas assim como Weber utilizou a metáfora da gaiola de ferro para se referir ao futuro da humanidade diante da expansão da racionalidade vida afora, também aqui há um lado cinzento. Esta 
dupla face da racionalização só pode ser enxergada através do exercício em mostrar como ela ocorre na vida social e por que meios. É o que se pode ver, por exemplo, nas formas encontradas por determinados grupos sociais para levar adiante suas perspectivas de reprodução social através da vida cotidiana, ou na tradução destes conteúdos em termos de regras formais e informais.

\subsection{1 - O desencantamento dos campos (ou racionalização e vida cotidiana)}

A imagem que se tem dos campos e de suas populações guarda uma estreita correspondência com um certo encantamento do mundo. Isto tem início nos ritos pagãos da Antiguidade, com as festas e oferendas aos deuses da terra, da fertilidade. Algumas destas práticas se metamorfosearam ou se prolongaram no tempo, não mais na forma de conteúdos mágicos, mas como permanências inscritas na tradição. Como foi visto nas páginas anteriores, mesmo estas formas correntes de tradicionalismo expressam, também elas, um forte conteúdo de desencantamento e de racionalização, o que poderia parecer paradoxal aos olhos do senso comum. O que acontece, como mostra Weber, é que tais práticas deslocam o sentido do mundo, de poderes sobrenaturais e imanentes às coisas para as formas pelas quais os homens orientam sua ação. Mesmo as benesses atribuídas aos santos, que enviam a chuva ou garantem boas colheitas, deixam progressivamente de se apresentar como o resultado de ações mágicas, de poderes liberados ou mobilizados, por exemplo, através do sacrifício de um animal simbólico ou algo que o valha, para serem entendidas como resultado de penitências e do merecimento derivado das formas de conduta que estas populações adotam visando ser dignas destes desígnios extraordinários. Em resumo, mesmo mediada pelo religioso, a ação dos indivíduos lhes resguarda uma relação de causalidade entre a maneira de condução ético-racional da vida e os resultados disto esperados. Em uma palavra, mesmo para acessar o extraordinário é preciso inscrever na dimensão intramundana as práticas capazes de levar a tanto.

Mais do que desencantamento, a vida rural cotidiana, nos tempos atuais, é crescentemente exposta a conteúdos sociais que reforçam, também ali, o movimento de crescente racionalização do mundo. Assim como na parte dedicada à nova etapa da ruralidade foi 
importante fazer referência à realidade dos países do capitalismo avançado, por ter sido ali que a urbanização foi mais longe, agora, para analisar a racionalização, talvez seja mais profícuo recorrer a exemplos de regiões mais pobres e precárias, por, inversamente, ser ali que a tradição se mostra mais presente.

Magalhães (2005) mostra este movimento de desencantamento e racionalização de maneira muito clara num estudo sobre as finanças de populações sertanejas tradicionais da Bahia. Ele parte, inicialmente, de exemplos da literatura do século XIX ao cinema do século XXI para mostrar como o sertanejo guarda em si a imagem da resignação e da conformação com suas condições sociais e de submissão às forças da natureza. O romance $O$ Quinze, de Raquel de Queiroz, ao retratar o flagelo da seca, mostra com profundidade os traços psicológicos de um povo que é pressionado por forças históricas e naturais e que se vê obrigado a aceitar fatalisticamente seu destino. Em Os Sertões, Euclides da Cunha traça o retrato de um sertanejo que, apesar de ser um forte é dominado pelas superstições e crendices conservadas pelo longo isolamento, que o tornam crédulo, místico, receoso. Magalhães nota ainda que, já nos anos recentes, no filme de Walter Salles, Abril despedaçado, adaptado do livro de Ismail Kadaré, a imagem da rotação incessante da bolandeira, uma roda de engenho movida por uma junta de bois, representa este destino imutável, o absoluto enraizamento da família na terra, no clima, prisioneira das tradições.

É este o tipo de população que Magalhães vai estudar para tentar compreender como eles conseguem se desfazer dos laços de dependência financeira, gerados pelos vínculos tão sedimentados de controle e de dominação típicos destes lugares. Seu ponto-de-partida é a a ação das Comunidades Eclesiais de Base e dos sindicatos de trabalhadores rurais, a partir dos anos 70, vista como decisiva para promover um processo de mudança cultural e a formação de uma densa rede de relações sociais novas ao contexto de então. Os "círculos bíblicos", as celebrações coletivas e as festas religiosas foram as primeiras e mais elementares experiências de construção de uma nova coesão social naquela região. As práticas religiosas populares eram organizadas por leigos, lideranças comunitárias, que além da missão religiosa promoviam discussões sobre a realidade local, os problemas dos agricultores, a importância das organizações e do levantamento e articulação das suas reivindicações e necessidades. Foi deste trabalho religioso que surgiram as primeiras 
associações comunitárias e as oposições aos sindicatos locais que, à época, reproduziam as relações tradicionais. Esta foi, enfim, a porta de entrada de um processo longo de racionalização da vida dos sertanejos. E foi também uma condição fundamental para viabilizar a formação de organizações que exigem, ao mesmo tempo, plena racionalidade econômica, cooperação e projeto social: as cooperativas de crédito.

É no mínimo curioso notar como, mais uma vez e repetindo aquilo que Pierucci (2003) mostrou para a longa trajetória de desencantamento do mundo, como a religião se institui portadora de um tal processo. Mas, obviamente, isto não é imanente às virtudes religiosas. Magalhães mostra como esta ação encontrou um ambiente histórico favorável onde pesaram igualmente: uma crescente monetarização da vida econômica local, com tudo o que isso tem de correspondente em termos de introdução do cálculo e de impessoalidade; o acesso crescente a tecnologias como a meteorologia, que serviu para, no mínimo, dividir com o religioso as explicações sobre as manifestações do mundo natural; e a existência de conflitos e relações de dominação, cuja metabolização e encaminhamento por parte destas populações só poderia se dar no plano da religião ou da política. Foi nas fissuras abertas por tais processos que a mediação da esquerda católica contribuiu com uma certa forma de compreendê-los e encaminhá-los num determinado sentido.

Através de outros estudos e pesquisas que tocam também nas condições de reprodução social de populações rurais é possível ver o que há de libertador, mas também o que há de desestruturação de todo um universo material e simbólico. Isto é particularmente visível naquelas situações que envolvem as dimensões geracional e de gênero. A análise de Abramovay et al. (2003) sobre os dilemas que cercam a transmissão do patrimônio familiar entre pequenos agricultores do sul do Brasil é extremamente elucidativa. O que os autores constataram, ao analisar a situação e as perspectivas de filhos de agricultores de certas áreas brasileiras, é que os tempos atuais trazem consigo o fim de um padrão específico de sucessão, muito antigo, o minorato. Durante várias gerações constituiu-se uma tradição que consistia em deixar com que o estabelecimento agrícola fosse herdado pelo filho mais novo. Esta convenção permitia, a um só tempo, que a família encaminhasse para o matrimônio as filhas moças, que parte da produção fosse destinada para a compra de lotes de terra aos 
filhos mais velhos, à medida que estes iam constituíndo suas próprias famílias, e permitia ainda que o filho mais novo ficasse assim preso à propriedade, garantindo não só moradia, mas o acompanhamento da velhice dos pais.

Este padrão implode por uma série de razões. Na raiz de todas elas está uma mudança nos padrões demográficos das regiões rurais. As filhas de agricultores são as que mais saem destes espaços. É muito comum que elas passem a habitar núcleos urbanos relativamente próximos ao, diante da falta de espaço na lógica de transmissão patrimonial no seio da família, procurar estudar ou trabalhar. Com isso, elas são inseridas em outros círculos sociais e aumentam seu capital cultural. Neste novo ambiente é comum que elas acabem contraindo o matrimônio, em geral tendo como parceiros pessoas não mais vinculadas à atividade agrícola.

Estas novas possibilidades oferecidas pelos núcleos urbanos - acesso a educação, infraestrutura, e até mesmo um mercado matrimonial mais diversificado e promissor - seduzem também os rapazes. E, em geral, torna-se difícil voltar às lides do trabalho rural após experimentar certos confortos e excitações que nestas regiões mais carentes ainda são mais comuns na vida urbana. Tanto é que o êxodo continua existindo ali onde o padrão de urbanização ainda não tornou viável às populações locais terem acesso a equipamentos sociais básicos e oportunidades sem que para isso seja preciso migrar. E, inversamente, naquelas regiões onde a coexistência dos espaços rurais e urbanos se fez de modo a garantir uma alta mobilidade entre os dois pólos, ali se tem visto não só um arrefecimento do êxodo rural como uma forte atração populacional.

Em ambas as situações, um traço inegável é que as habilidades agora exigidas para a gerência e boa performance dos estabelecimentos rurais não podem mais se resumir àqueles conhecimentos transmitidos de pai para filho. As novas dinâmicas econômicas que condicionam a atividade agrícola ou outras realizadas nos estabelecimentos rurais impõem um maior grau de exigência quanto a habilidades gerenciais, de identificação e conquista de 
mercados específicos, conversão de produtos e culturas. Aspectos, enfim, que pressupõem um maior domínio técnico sobre o tradicional trabalho rural ${ }^{99}$.

Em todos estes casos se trata de situações onde as formas de condução da vida cotidiana por populações rurais sofrem um deslizamento nas suas formas de enraizamento social, de uma situação antes pautada pela tradição e pelos vínculos com o mundo agrário e que agora se desloca para a integração entre esferas, fazendo-se acompanhar de crescente desencantamento e racionalização. O conteúdo destas formas de racionalização da vida cotidiana não é dado de antemão, ele se estabelece com o sentido da ação social para os agentes, no que importam tanto sua estrutura cognitiva constituída, como o campo de possibilidades e de interações em que ela atua, um campo determinado pelas injunções entre o meio-ambiente, as estruturas sociais e as instituições.

\subsection{2 - Da regulação total, à regulação setorial, à regulação territorial (ou racionalização e instituições)}

Enquanto a vida cotidiana mostra como a racionalização penetra naquilo que há de mais individual nas relações sociais, as instituições permitem perceber como ela se expressa em formas propriamente societais. Também aqui é preciso destacar que se trata de um tipo de racionalização muito antigo. Mesmo em populações as mais tradicionais é facilmente possível encontrar regras que regem as formas de apropriação e uso de recursos naturais. Isto começou já com a definição de direitos de propriedade no surgimento mesmo da agricultura e adquiriu seus contornos mais nítidos na modernidade recente, quando não só o uso do solo é objeto de forte regulamentação, mas também o volume, a qualidade, o destino, e os processos de produção na agricultura e na criação animal. A grandeza e a

\footnotetext{
${ }^{99}$ Ver a respeito, para o caso francês, um tratamento de fenômenos muito similares a estes vistos no sul do Brasil em Bourdieu (2002), Champagne (2002). Livros que tem os sugestivos títulos "L'heritage refusé" e "Le bal des celibataires". Também a pesquisa de Heather et al. (2005) sobre mulheres em Alberta, mostrou os conflitos inerentes a estas mudanças e maiores entrelaçamentos entre ações antes determinadas mais diretamente pela tradição e agora expostas às forças emanadas da integração entre mercados de trabalho urbano e rural, entre expectativas familiares e sociais. As mulheres entrevistadas relatavam que a reestruturação havia afetado suas decisões, a forma de organizar-se em torno do trabalho profissional e do trabalho doméstico não reconhecido e não remunerado. Elas falam do peso da dupla expectativa que sobre elas repousa e da necessidade que sentem em tentar corresponder a ambos, o que muitas vezes leva a problemas de saúde e sérios dramas psicológicos.
} 
extensão das formas de regulação sobre o espaço rural podem ser dimensionadas pelo fato de que a maior parte do orçamento da União Européia é consagrada aos gastos com a política agrícola e que, dentre as inovações trazidas nos anos mais recentes, é na promoção da dinamização de economias rurais que se encontram boa parte dos mais profícuos esforços. Neste caso, a novidade não é tanto a existência destas instituições, mas sim o peso e a direção que elas adquirem no período mais recente.

Construídas em grande parte sob os auspícios do modelo produtivista e, portanto, orientadas para este fim, as formas de regulação do espaço rural têm passado crescentemente de um compromisso em torno dos aspectos setoriais que envolvem a produção agrícola para um compromisso territorial (Coulomb, 1991). Na Europa, a reforma da PAC é o exemplo mais claro. Ali os critérios que se traduziam em garantias e estímulos aos produtores agrícolas vêm sendo, muito lentamente e a duras penas, substituídos por mecanismos que impulsionam a preservação das paisagens, um maior cuidado com os riscos de contaminação de águas e solos, uma valorização dos aspectos não diretamente mercantins, enfim. Isto tem reforçado muito mais os instrumentos de políticas anteriormente existentes e que já atuavam na dimensão espacial, como as políticas regionais e de ordenamento territorial. Os dados reunidos por Veiga (2005) sobre a Itália são impressionantes. Em primeiro lugar, 11\% da superfície do país faz parte do sistema de unidades de conservação, como parques, reservas e áreas protegidas. Segundo, algo como $15 \%$ do território está inserido no sistema de incentivos do Programa Natura 2000 e que prevê sua inclusão num sistema de Zonas Especiais de Conservação. A dimensão crescente da regulação dos espaços naturais pode ser mensurada no subtítulo de um instigante livro de Bertrand Hervieu - Le retour à la nature: au fond de la forêt... l'État. Isto é, mesmo ali, onde o mundo natural parece estar mais longe da interferência das instituições é impossível escapar às regras e convenções.

$\mathrm{Na}$ América Latina a direção é similar, apesar das diferenças históricas e estruturais. Mesmo com todas as restrições, no Brasil um terço dos agricultores familiares já tem acesso a sistemas de financiamento. Se a transição nas políticas de desenvolvimento rural do viés setorial ao territorial ainda é tímida, como foi visto no Capítulo 3, todo o arcabouço 
de leis ambientais não é nada desprezível. Ehlers (2004) mostrou claramente como as possibilidades de dinamização e de conservação das áreas rurais não podem ser compreendidas sem que se faça referência às instituições que regulam o comportamento dos agentes no que diz respeito aos recursos naturais. Mais recentemente, a introdução de uma nova legislação para exploração econômica das florestas tende a sinalizar um novo caminho, onde a interferência das instituições certamente crescerá ainda mais.

\subsection{3 - Quem são os agentes da nova ruralidade ? (ou racionalização e estruturas sociais)}

A afirmação do espaço rural como objeto pertinente de compreensão pelas ciências sociais passa pelo delineamento do seu significado como esfera social do mundo contemporâneo. Este conceito, central na sociologia weberiana e em muito similar ao conceito de campo em Bourdieu, tem em seu núcleo lógico a afirmação de que a unidade em questão - neste caso o espaço rural - representa uma esfera relativamente autônoma do mundo social: relativamente no sentido de que há injunções com outras esferas, e autônoma porque é governada por "regras" específicas que governam sua estrutura e dinâmica. Estas regras expressam o conteúdo de racionalização que governa esta esfera, e este conteúdo, por sua vez, é indissociável tanto da compreensão que os agentes sociais têm sobre os valores e formas de condução ético-racional no interior deste espaço, como da racionalização social que se expressa na formação das instituições formais e informais.

Com o deslizamento de significado que ocorre nas três dimensões definidoras da ruralidade - a relação com a natureza, as relações de interconhecimento e os vínculos com o sistema de cidades -, torna-se necessário compreender em termos teóricos o que muda nas articulações entre estruturas sociais, instituições e no enraizamento ambiental no novo momento. Nas seções que compõem este capítulo, tentou-se demonstrar como a idéia de racionalização da vida rural permite remeter às várias dimensões aqui implícitas, em particular aquelas mais destacadas pela literatura contemporânea: a necessidade de uma abordagem de longo prazo, a importância em compreender a heterogeneidade e a manifestação desigual da nova direção dos processos de desenvolvimento rural, e a 
inevitabilidade de se recorrer a uma abordagem que não privilegie apenas as interações, mas também as estruturas e conflitos a elas inerentes. Mas, se o movimento de racionalização da vida rural e se os novos conteúdos empíricos da nova ruralidade não são lineares, o que determina a diferenciação ? É possível esboçar seus contornos mesmo que esquematicamente ? Os desenhos a seguir têm a intenção de ilustrar o que poderia ser um sistema de oposições típico da "nova ruralidade". Seus agentes podem ser identificados, a partir de análises concretas de situações objetivas, a partir de sua posição nesta estrutura.

O desenho 1 se refere ao sistema de oposições da ruralidade pretérita e comporta dois eixos. No eixo $\mathrm{X}$ os territórios rurais variavam a sua posição a depender do maior ou menor grau de integração aos sistemas agroindustriais. Este é um eixo que permitia uma aproximação capaz de caracterizar a intensidade de erosão das condições de autonomia das comunidades rurais por aquilo que por muito tempo a literatura convencionou chamar genericamente por “penetração das relações capitalistas no campo". Era desta crescente integração à sociedade urbana e industrial o que falavam estudos clássicos como os de Antonio Cândido (1964) e Maria Isaura Pereira de Queiroz (1979). No eixo Y, a posição varia de acordo com o maior grau de concentração e de especialização destes territórios. Esta oposição remete, de um lado, à distribuição dos trunfos, habilidades ou capitais, a depender da orientação teórica em questão e, de outro, combinadamente, à maior possibilidade de que ali sejam geradas as instituições necessárias à dinamização econômica acompanhada de maior coesão social.

Já o desenho 2 se refere ao sistema de oposições da nova ruralidade. No eixo X, os territórios rurais passam a variar sua posição a depender do maior ou menor grau de utilização de novas formas de uso social de recursos naturais. Neste eixo a oposição se desloca do grau de integração do rural para uma nova qualidade de integração, aquela ditada pela nova forma de enraizamento ambiental da ruralidade e seus correspondentes para as estruturas sociais e as instituições. No eixo Y mantém-se a variação das posições de acordo com o maior grau de concentração e de especialização destes territórios, já que também na nova ruralidade os processos de desenvolvimento obedecem, em parte, às 
mesmas regras de outras esferas e tem a ver com desconcentração e diversificação dos tecidos sociais e também dos ecossistemas. 


\section{Desenho 1}

Sistema de oposições da ruralidade pretérita

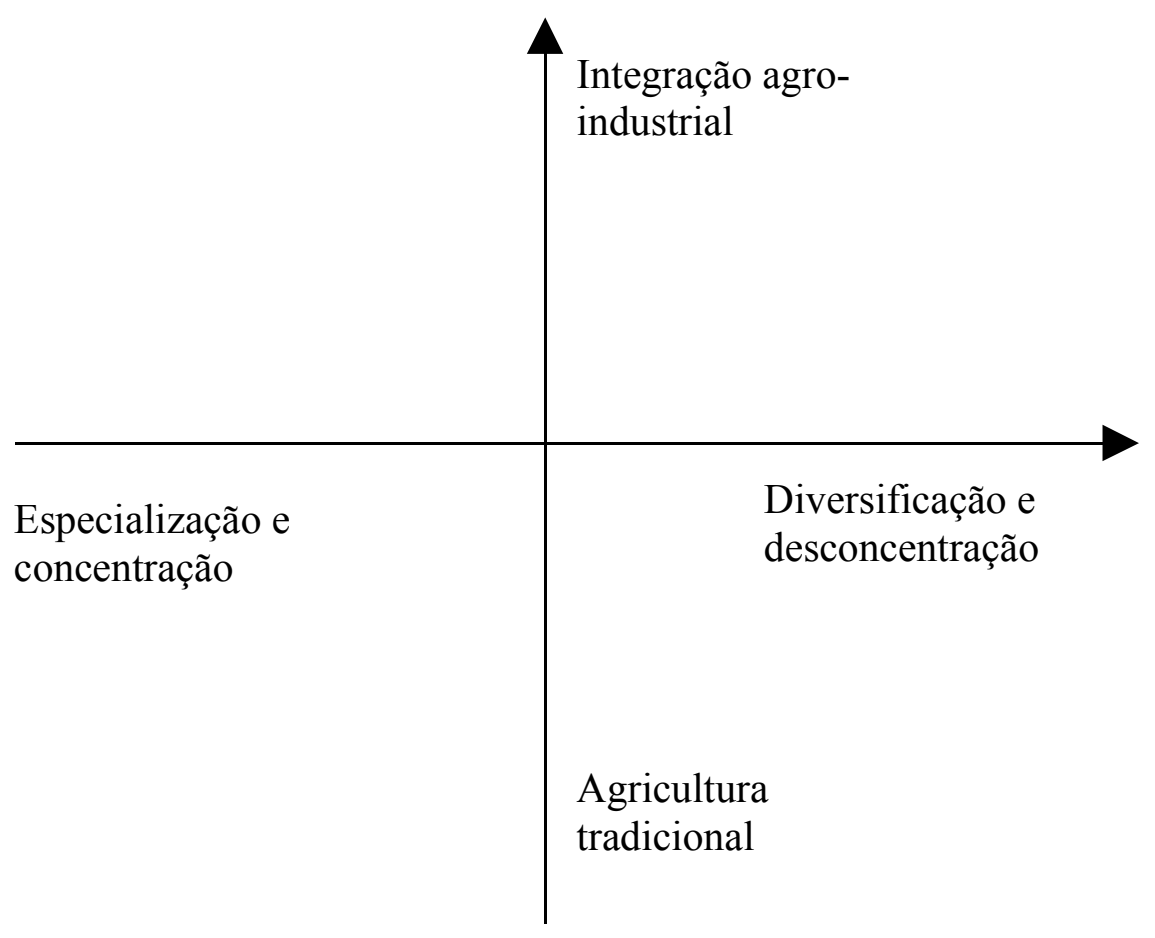

\section{Desenho 2}

Sistema de oposições da nova ruralidade

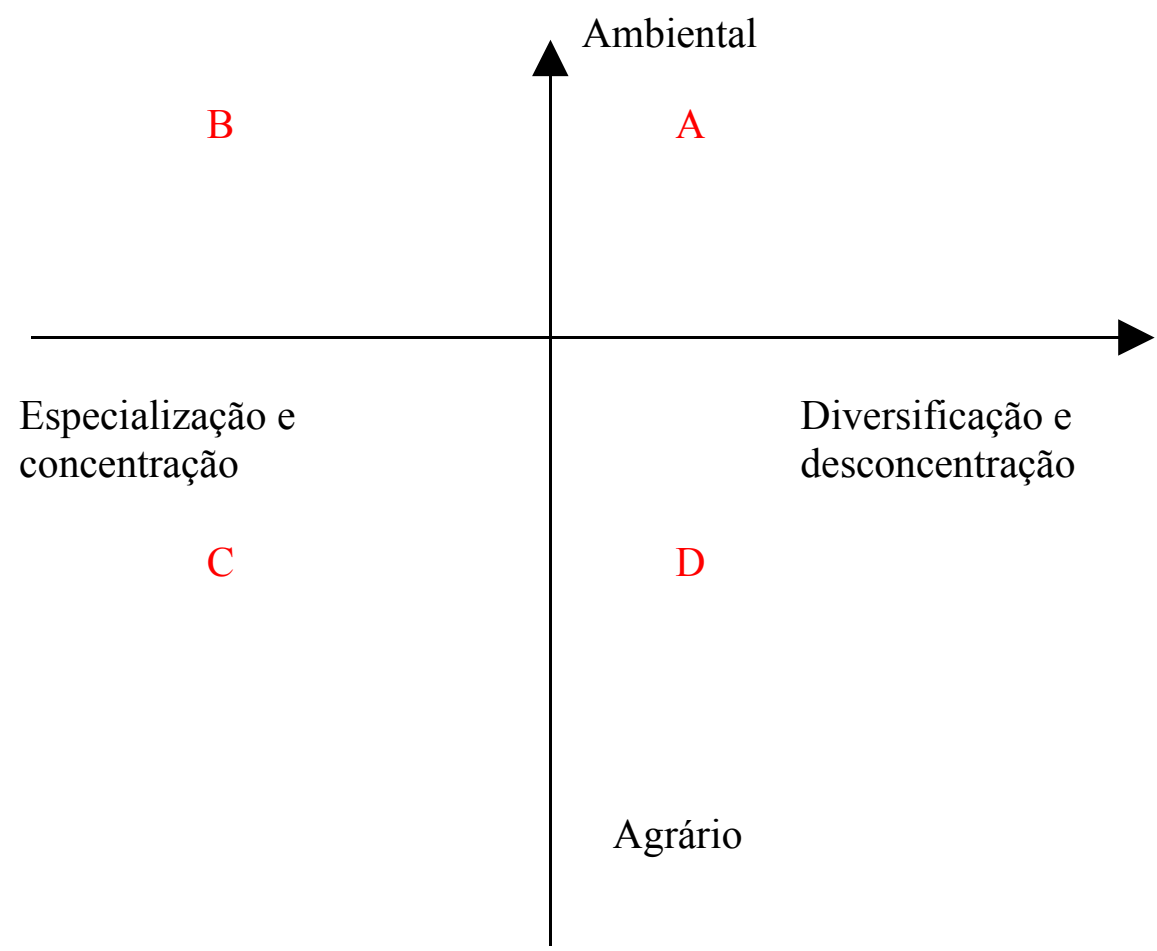


Em linhas gerais, os quatro quadrantes que surgem neste desenho poderiam ser definidos de acordo com seus significados em termos de enraizamento ambiental, estruturas sociais e instituições.

\section{Situação A -}

\section{Ruralidade ambiental e estruturas sociais mais diversificadas e desconcentradas}

Um determinado padrão de urbanização associado a características morfológicas do território, envolvendo o meio-ambiente e a estratificação social, favoreceu a que ali se criasse uma forma de uso social dos recursos naturais onde a busca pela conservação encontra correspondentes em formas de dinamização da vida social. A diversificada economia local conta com um alto grau de integração econômica e de coesão territorial. Paisagem, cultura e economia se entrelaçam de uma maneira a fazer com que se consiga associar a dinamização econômica com bons indicadores sociais e com desempenho positivo em indicadores ambientais. Algo semelhante é o que ocorre em regiões como o Vale do Itajaí, em Santa Catarina.

\section{Situação B -}

\section{Ruralidade ambiental e estruturas sociais mais especializadas e concentradas}

Embora as características morfológicas do território, no que diz respeito ao meio-ambiente, favoreçam a conservação, as características da estratificação social não contribuem para que ali sejam criadas as instituições capazes de diminuir as fraturas entre grupos sociais por conta de sua posição social. A conservação encontra-se em conflito com as possibilidades de dinamização da vida local. O padrão de urbanização é ainda incipiente ou não se deu numa direção onde não houve uma valorização do rural. Este é o caso típico de certas áreas da Amazônia, onde a presença da floresta convive com o avanço da agricultura de negócios. As estruturas sociais locais não apresentam vigor e um padrão de interação suficiente para fazer frente ao movimento de expansão das atividades primárias, resultando em perda de biodiversidade e em depleção dos recursos naturais como terra e águas. Há 
um alto grau de conflito entre instituições e as populações locais são fortemente afetadas por eles.

\section{Situação C -}

\section{Ruralidade setorial e estruturas sociais mais especializadas e concentradas}

As características morfológicas do território em termos ambientais e sociais engendram uma relação de exploração com o rural com restritas possibilidades tanto de conservação como com maior risco de esgarçamento dos tecidos sociais, apesar da possível dinamização econômica com o setor primário e de transformação. As regiões que experimentam um

forte dinamismo dependente da atividade agrícola se encaixam neste tipo. Ali a riqueza gerada estabelece uma relação entre o município pólo do território e os demais onde todos os recursos são concentrados, não resultando em expansão da riqueza para o conjunto dos grupos sociais. As possibilidades de conservação ambiental são restritas aos mínimos exigidos por lei, como no caso de preservação de remanescentes, matas ciliares e vegetação de topo de morro. A biodiversidade local é fortemente comprometida ou ameaçada pelo vigor da exploração agrícola comercial. Nos casos das regiões mais dinâmicas, como algumas áreas do interior do Estado de São Paulo, o padrão de urbanização oferece uma infra-estrutura e serviços até razoáveis, mas concentrados. Em outras, menos dinâmicas, a especialização setorial e o enrijecimento das estruturas sociais levam ainda a um padrão onde impera a precariedade, caso das regiões cacaueira na Bahia ou na Zona da Mata pernambucana.

\section{Situação D -}

\section{Ruralidade setorial e estruturas sociais mais diversificadas e desconcentradas}

São situações onde, embora as características morfológicas do território já não sejam tão promissoras no que diz respeito aos recursos naturais, as estruturas sociais poderiam favorecer um processo de mudança e de criação de novas instituições. No entanto, as formas de dominação econômica impedem ou bloqueiam esta inovação. Há fissuras entre o setorial e o ambiental, e entre os grupos sociais. Um exemplo deste tipo de território é o 
Oeste Catarinense. Uma concentração de grandes empresas agroindustriais convive com uma estrutura social baseada num expressivo segmento de agricultores familiares. A região apresenta uma dinâmica econômica razoável, mas convivendo com indicadores sociais e de desigualdade não tão bons e com vários problemas ambientais relativos a solos e águas. As possibilidades de reprodução dos grupos sociais locais ainda depende muito dos vínculos extra-locais favorecendo a perda de recursos humanos valiosos. Com isso bloqueia-se a possibilidade aberta pela configuração social local de maiores interações e de criação de novas instituições capazes de mudar o rumo do desenvolvimento territorial.

O caráter emergente da nova ruralidade fará com que, usando novamente a representação esquemática, a parte inferior ao eixo $X$ se desloque, diminuindo sua importância quantitativa, e que em seu lugar surja uma nova oposição. Este esboroamento das sociedades agrárias, expresso tanto no movimento indicado na passagem do desenho 1 ao desenho 2 e seus correspondentes campos de oposição só adquire contornos de fatalidade nos marcos do paradigma agrário. Ali, trata-se da diluição de um mundo social, com o que isto tem de tragédia e de criação. De tragédia porque ficaram prisioneiras do sistema de oposições típico de seu tempo. De criação porque o novo sistema de oposições abre possibilidades antes não claramente inscritas.

Assim como para o capitalismo o tipo puro se deu quando a racionalidade prático-técnica propiciada pela evolução das condições cognitivas e materiais da época encontrou a racionalidade prático-ética da cultura protestante, fazendo assim eclodir uma enormidade de possibilidades tanto na criação de instituições condizentes com este novo momento como na introdução de mudanças nas formas de condução ético-cotidiana da vida (Pierucci, 2003), talvez não seja exagero dizer que a possibilidade histórica de ocorrência de um tipo puro como a situação $\mathrm{A}$ indicada neste desenho representa igual teor no que diz respeito às tentativas de se equacionar as dimensões presentes na retórica do desenvolvimento sustentável. Isto é, se a utopia do século XXI, para usar os termos de Veiga (2005), consiste neste anseio por melhorar a condição humana e natural através da dinamização econômica com ampliação das possibilidades das pessoas e com conservação ambiental, é preciso, antes de mais nada, reconhecer que determinadas configurações territoriais tem 
conseguido fazê-lo. E isto ocorreu ali, onde o urbano e o rural não estabeleceram desenvolvimentos concorrentes e inconciliáveis, mas antes integrados e co-determinados. Mais ainda, esta possibilidade histórica não foi resultado exclusivo da introdução unilateral ou exógena de nenhuma norma ou sanção, mas sim da evolução de configurações historicamente determinadas, em cuja trajetória houve um crescente processo de racionalização, permitindo que, nestes termos mesmo, a um só tempo ecológicos, históricos e racionais, se constituíssem as estruturas sociais e as instituições necessárias para tanto.

Na nova ruralidade, passível de compreensão por uma abordagem territorial, não é possível mais identificar um ator ou grupo social predominante, como na ruralidade pretérita. A intersetorialidade que marca as economias locais e a heterogeneização crescente de suas populações exige um reconhecimento compreensivo, em profundidade, das dinâmicas e dos agentes que delas são portadores. E isso só é possível por meio da análise da evolução desta configuração territorial, das formas de racionalização que lhe correspondem, e das posições sociais de seus agentes, tal como aqui se tentou esboçar ${ }^{100}$.

\footnotetext{
${ }^{100}$ Para uma explanação sobre a complementaridade entre a noção de campo e as dinâmicas de longo prazo, ver Champagne \& Christin (2004).
} 


\section{Síntese do Capítulo 5}

Um traço marcante da nova ruralidade é o crescente processo de racionalização da vida rural. Um primeiro domínio onde isso se expressa são as formas de condução ética do cotidiano, cada vez mais pautadas pela ação racional, seja com relação a fins ou com relação a valores, e menos pela ação tradicional ou por formas mágicas de relação com o mundo. Outro são as instituições, entendidas como meios de racionalização de conflitos e interesses e de sua materialização em compromissos formais e informais, em regras sociais. Nos dois casos o rural adquire um novo sentido, pois passa a ser um lugar onde é possível uma vida crescentemente conduzida e onde os conteúdos sociais que informam as estruturas cognitivas e os espaços dessa interação não obedecem mais aos signos do isolamento e das raízes agrárias, mas sim de uma maior aproximação entre o rural e o urbano, entre natureza e sociedade.

Como toda esfera do mundo social que passa por processos de racionalização, o rural também apresenta regras e agentes que lhe são específicos. Um desdobramento desta nova condição do desenvolvimento rural é a tensão conflitiva atual que decorre de três disjunções relativas às instituições, às estruturas sociais, e ao meio-ambiente: a) do fato de que há uma sobreposição de configurações de agentes e interesses - alguns mais vinculados aos fatores presididos pelos aspectos ambientais, outros pelos aspectos econômicos, outros ainda pelos aspectos políticos ou culturais -, quando na "velha ruralidade" havia um agente principal: o agricultor ou as empresas agrícolas; b) de uma incoerência ou no mínimo de atritos entre instituições, quando na etapa anterior o conflito que estava na base das instituições dizia respeito, sobretudo, ao uso do solo através do direito à exploração econômica das atividades primárias; c) de uma contradição entre as formas sociais de racionalização, que têm na mercantilização uma de suas mais extremas manifestações, e o uso social de recursos não diretamente mercantis, como a natureza . 


\section{Conclusão}

"O que herdaste dos pais, reconquista-o se queres possui-lo realmente"

Do Fausto, de Goethe

"Ali onde isso era, devo vir a me tornar"

Do Esboço de psicanálise, de Freud

Giancarlo Ricci, um estudioso da obra de Freud, lembra que seus escritos são pontilhados por numerosas citações de Goethe. Uma delas, a que consta aqui em epígrafe, estava entre suas prediletas. E a idéia central nela contida foi transmutada para o Esboço de psicanálise, nos termos também destacados acima. Ricci (2005:200) lembra que a frase é celebre e constitui um emblema luminoso da psicanálise: "é como um cristal no qual duas superficies se conjugam e tornam-se uma só e afiadíssima luz. A vírgula que divide a frase intersecciona, divide, separa os dois tempos lógicos do mito, mas também os mantém unidos e os coloca em relação". Em Goethe a ênfase é colocada numa ocorrência relativa à conquista, em Freud, no devir. Nos dois casos, o destino se abre como algo a ser projetado, escrito, desenvolvido; se apresenta como possibilidade, por sua vez inscrita num campo cujos contornos e limites são dados, de um lado, por esta mesma herança, como reflexo destas mesmas estruturas a um só tempo objetivas e subjetivas, materiais e simbólicas; e de outro, pelo ambiente no qual as interações nesse campo ocorrem. Passado como herança e futuro como projeto se entrelaçam no presente, que se deixa ver ou como possibilidade concreta, a ser experimentada no cotidiano, ou como resultado da análise teórica, a ser demonstrada em termos científicos.

Ao longo de cada uma das quatro partes que compõem esta tese foi possível falar de aspectos pertencentes a este entrelaçamento. Neste caso, é claro, não tendo por objeto direto a dimensão de que fala Freud - a psique -, mas abordando também mais uma espécie de 
mito, representado pela idéia de desenvolvimento rural. Um mito não na concepção falseadora com que a palavra é algumas vezes utilizada (Rist, 2001), mas no seu sentido mais positivo e que serve tanto aos propósitos da psicanálise como das ciências sociais, como organizador de sistemas de interpretação, classificação, e mobilização do mundo social (Furtado, 1974).

O objetivo deste estudo consistia em procurar estabelecer a diferença conceitual contida na emergência da abordagem territorial do desenvolvimento rural. Procurou-se recorrer a aspectos relacionados àqueles mesmos dois tempos lógicos: aquele relativo ao "onde isto era", às permanências verificadas nas sucessivas metamorfoses do mito, do pensamento, da idéia, do conceito, e aquele relativo ao "vir a tornar-se", não como desejo normativo, mas através da compreensão e explicação dos processos sociais subjacentes tanto às lógicas de mudança e de realização do futuro como, igualmente, aos mecanismos de bloqueio e de resistência à mudança.

Mais do que repetir os achados já expressos nas sínteses das partes individuais em que o texto está organizado, esta conclusão tem por principal intuito, além de reafirmar a tese apresentada na introdução à luz destas sínteses, destacar algumas implicações teóricas de tudo o que foi exposto e como isso se desdobra em novas questões, que poderiam, juntas, conformar um interessante programa de pesquisas compatível com uma visão territorial do desenvolvimento rural.

\section{A erosão de um paradigma e a racionalização da vida rural}

A tese, formulada na Introdução e exposta nas quatro partes apresentadas anteriormente, pode ser resumida em duas afirmações principais.

Primeiro, os processos sociais subjacentes àquilo que a literatura das ciências sociais aplicadas convencionou chamar por nova ruralidade trouxeram consigo uma erosão das bases empíricas que estavam na raiz do paradigma clássico de explicação do desenvolvimento rural, em cujo cerne estava sua redução aos aspectos agrícolas e agrários, 
ou em outros termos, à sua dimensão setorial. A relação entre sociedade e natureza, que encerra um primeira traço distintivo da ruralidade, é objeto de um deslocamento onde as formas de uso social dos recursos naturais passam do privilégio à produção de bens primários a uma multiplicidade de possibilidades onde se destacam aquelas relativas à valorização e aproveitamento das amenidades naturais, à conservação da biodiversidade, e à utilização de fontes renováveis de energia. As relações de proximidade, segundo traço distintivo da ruralidade, também são alvo de um deslocamento: a relativa homogeneidade que marcava as comunidades rurais dá lugar a uma crescente heterogeneização e um certo esgarçamento dos laços de solidariedade que eram a marca da ruralidade pretérita. A relação com as cidades, último traço distintivo, deixa de se basear na exportação de produtos primários para dar origem a tramas territoriais complexas e multifacetadas, com diferentes mecanismos de composição entre os dois pólos, agora baseados em novas formas de integração entre os mercados de trabalho, de produtos físicos e serviços, e também de bens simbólicos. De exportadora de recursos como bens materiais e trabalho, os territórios rurais passam a ser atrativos de novas populações e de rendas urbanas. Em suma, desaparece todo o sentido em tratar o rural exclusivamente como o oposto do urbano, em proclamar seu desaparecimento, ou em resumi-lo a apenas uma de suas dimensões atuais: o agrário. O significado maior disso tudo é, como foi dito, o esboroamento da visão predominante que sustentou as ciências sociais aplicadas sobre o rural durante todo o século passado.

Segundo, um aspecto marcante do rural contemporâneo é a penetração crescente em todas as esferas da vida rural de um longo processo de racionalização que se manifesta em formas cada vez mais desencantadas de condução da vida por parte destas populações, em mecanismos e instituições cada vez mais complexos de regulação destes territórios e das formas de acesso e uso dos recursos naturais, e a uma mudança nas estruturas sociais locais com a introdução de novas populações, uma valorização cada vez maior dos conteúdos técnicos e instrumentais, o estilhaçamento dos interesses e conflitos que antes eram unívocos e tendiam a derivar das formas de posse e uso da terra. Não se trata de afirmar que toda a população rural transformou-se em calvinistas à imagem weberiana d'A Ética protestante e o espírito do capitalismo, mas de constatar que, mesmo sendo o lugar por 
excelência onde ainda mais se valoriza a proximidade com a natureza e a tradição, isto se faz sob conteúdos sociais totalmente novos, como se tentou demonstrar acima. Com a racionalização da vida rural, é todo um universo ancorado na ruralidade agrária que se dilui, para dar lugar a novas significações. Permanência do rural, associada à heterogeneização e aos conflitos disso derivados passam a ser palavras-chave para compreender suas manifestações contemporâneas.

\section{Um novo paradigma?}

É neste contexto que emerge a abordagem territorial do desenvolvimento rural, na confluência entre um discurso normativo - que busca dar conta destas novas formas de manifestação, para além de um setor econômico, e para além dos limites de uma comunidade, sinalizando uma escala geográfica que permite comportar a relação com o urbano -, e um discurso científico - cuja preocupação é reconhecer o conteúdo empírico e os significados teóricos destas dinâmicas sócio-espaciais. Isto chega a conformar um novo paradigma para compreender o desenvolvimento rural ?

É demasiadamente cedo para arriscar uma resposta definitiva. Como se viu, a consolidação da visão agrária do rural foi resultado de séculos de sedimentação de conteúdos empíricos e cognitivos, e a emergência da abordagem territorial não tem mais do que três décadas. O que se pode afirmar é que, apesar de uma maior aderência às tendências atuais, a idéia de território tem sido incorporada ao discurso de agentes públicos e muitas vezes também no meio acadêmico como uma espécie de "inovação por adição". Ela passa a freqüentar o vocabulário de organizações, governos e cientistas, mas quase sempre sem trazer consigo a necessária superação da visão agrária do desenvolvimento rural. E isto não é resultado somente da cristalização do paradigma clássico nos sistemas mentais partilhados, para usar os termos de North. Mas sim, expressão de interesses ancorados na situação anterior e que bloqueiam inovações mais profundas, seja na forma da manutenção de especializações disciplinares que não mais se sustentam nos mesmos termos, seja na forma da divisão de competências entre esferas de governo voltadas para o rural cujas atribuições não podem mais ser eficientes nos mesmos termos de outrora. 
Por tudo isso o título desta tese coloca em questão os paradigmas do desenvolvimento rural, assim, no plural: o clássico, que restringe o rural ao agrário, e o emergente que tateia sua compreensão sob um enfoque territorial.

\section{Desdobramentos}

Se estas são as conclusões principais, há outras a que se pode chegar como seu desdobramento.

Instituições: Mais do que as regras do jogo, mecanismos formais e informais que incidiriam condicionando o comportamento dos agentes, há também um jogo das regras. Os valores, visões, convenções e aparatos legais são produto da ação de agentes encarnados, com interesses específicos. Compreender a dinâmica das instituições do desenvolvimento rural não é algo que se alcance a partir de uma abordagem formalista nem meramente cognitiva. É preciso alcançar aquilo que se poderia chamar por embeddedness das instituições, seu enraizamento nas estruturas sociais que lhe sustentam. Fazê-lo significa interrogar quem são os agentes da velha e da nova ruralidade, por meio de que práticas levam seus interesses adiante, e mobilizando que tipo de recursos.

Estruturas sociais: Mesmo com a crescente valorização do local e do territorial, não ajuda a compreensão rigorosa do desenvolvimento rural a afirmação contida na provocativa formulação de Beccattini, encampada por Magnaghi (2003), e que sugere a passagem "da consciência de classe à consciência do lugar". Se é verdade que os aspectos classistas, no sentido clássico, perderam centralidade na explicação dos conflitos sociais contemporâneos, é preciso também reconhecer que os territórios não podem ser ator social, pelo simples fato de que a ação social precisa ter por portadores sujeitos concretos, e que o território é justamente uma escala específica de processos levados adiante por agentes com interesses particulares e muitas vezes conflitantes. 
Meio-ambiente: As obras de Jared Diamond e de Jane Jacobs mostram como desde as antigas sociedades o meio-ambiente é variável-chave nos destinos da humanidade. No caso do rural esta importância é ainda maior por tratar-se da fronteira entre os espaços mais altamente artificializados, as cidades, e a natureza. A idéia de territórios rurais permite justamente entrever as possibilidades de se tomar uma unidade de análise onde a urbanização crescente e dominante encontra diferentes formas de uso social dos recursos naturais. Isto não passa somente pela mercantilização da natureza, como defende uma importante corrente da economia, mas sim pela criação de instituições capazes de moldar a ação humana numa direção mais conciliadora com a necessidade de conservar os ecossistemas, paisagens, culturas. Daí a importância da ecologia para a explicação do desenvolvimento rural. E daí a importância do tema da mudança institucional. Por que caminhos podem ser construídas estas instituições?

Mudança: As características do tecido social e econômico de um território importam na configuração do campo de possibilidades em que se inscreve seu futuro. As regiões que têm em sua base estruturas sociais mais diversificadas e desconcentradas - como é o caso de vários espaços de predomínio da agricultura familiar, ou de pequenas e médias empresas apresentam melhores possibilidades de criar instituições e articulações capazes de trazer a dinamização econômica acompanhada da melhoria das condições de vida da maior parte da população, em vez de um crescimento concentrado nas mãos de poucos, como é típico dos territórios baseados em grandes e especializadas empresas. Uma idéia que contraria tanto o senso comum, maravilhado com os êxitos recentes da exportação brasileira de grãos, por exemplo, como muitas vertentes explicativas da ciência econômica, para quem economias de escala são muitas vezes o único critério de eficiência. Não faz sentido, portanto, opor a questão agrária ao desenvolvimento rural. Trata-se, sim, de entender as permanências dos conflitos históricos agora metamorfoseados, mas ainda presentes.

De tudo isso, talvez a mais destacada constatação seja o fato de que o desenvolvimento rural é uma categoria pertinente de compreensão do mundo. Isto se justifica tanto pela permanência da ruralidade como característica marcante de boa parte dos espaços nos países da periferia do capitalismo, mas também no chamado núcleo central da economia mundial, como pela possibilidade de se definir teoricamente o que é o rural, distinguindo-o 
do urbano, e o que é o desenvolvimento, para além do viés normativo ou do discurso ideológico. Ao operar esta distinção, não se deve dicotomizar os dois pólos, o rural e o urbano, como foi tantas vezes aqui enfatizado. Em vez disso, a afirmação da diferença entre ambos deve servir para realçar o que lhes é específico e, ao mesmo tempo, para identificar as instâncias empíricas através das quais se possa vislumbrar o conteúdo relacional dos dois domínios. Compreender os fenômenos relativos ao desenvolvimento rural significa, pois, buscar o entendimento da complementaridade conflituosa que cerca a evolução de determinadas configurações territoriais, onde os traços definidores da ruralidade se compõem sob formas distintas e historicamente situadas de articulação com o urbano.

A racionalização crescente da vida rural, justamente porque heterogênea e incompleta, é uma idéia que permite explorar em termos explicativos um tal enfoque. Ela permite erigir uma hipótese que alcance a dinâmica de longo prazo que envolve as mudanças no sentido do rural contemporâneo, ela fornece um parâmetro para a análise de sua manifestação desigual, e ela remete à existência de portadores sociais com interesses constituídos. Apesar desta forte aderência ao objeto em estudo - o desenvolvimento rural -, não há, aqui, nenhuma pretensão exclusivista em relação a modelos concorrentes. Como ensinou Florestan Fernandes, os diferentes métodos das ciências sociais não só podem como devem ser combinados, seja porque cada um é mais apto a iluminar determinados aspectos da vida social, seja porque eles podem corresponder a determinadas etapas do pensamento científico. Se, como disse Jane Jacobs (2003: 498), a relação entre o urbano e o rural pode se dar "de modo que os seres humanos possam ter condições de prezar o restante do mundo natural em vez de amaldiçoa-lo", isso passa necessariamente pelos conflitos inerentes ao caráter territorial do desenvolvimento rural. A conexão da racionalidade prática referente a fins com a racionalidade prática referente a valores, nos termos de Pierucci (2003), "é algo que projeta a figura de um verdadeiro big bang de possibilidades inauditas e especificamente modernas de expansão e extensão da racionalidade vida afora, explosão inaugural que descerra as condições de possibilidade de se fazer da vida uma vida crescentemente conduzida". Pode ser que os termos em que se consolida o desenvolvimento rural neste novo momento da história da humanidade esteja trazendo consigo esta possibilidade tão acalentada na retórica do desenvolvimento sustentável: a 
possibilidade de se conciliar os imperativos sociais de uso do espaço e as necessidades naturais de conservação da natureza.

\section{Para um programa de pesquisas}

O objetivo desta tese era elucidar o significado social e teórico da emergência da abordagem territorial. Talvez sua principal contribuição seja essa: ao lado da constatação da falência do paradigma clássico, fundado na visão agrária do rural, afirmar a possibilidade de que se possa estar entrando em um momento da história da humanidade onde ao rural não seja mais relegado somente o destino do atraso, da estagnação e da tradição. Justamente por esta característica, há uma série de interrogações que daí surgem e que poderiam ser enfrentadas em um ou mais programas de pesquisas.

Sabe-se, como mostrou o Projeto Rurbano, que a composição das rendas das famílias de agricultores apresenta uma tendência declinante de ingressos provenientes da atividade primária. Sabe-se igualmente, como mostrou o Projeto CUT/Contag, que a melhoria dos rendimentos destas famílias depende das configurações territoriais nas quais elas estão inseridas. Mas pouco se sabe sobre o que determinou a evolução histórica de tais configurações. A afirmação aqui apresentada, baseada, sobretudo, nos achados de programas de pesquisa internacionais, de que as estruturas mais desconcentradas e diversificadas favorecem a formação de instituições que podem levar à convergência de taxas privadas e sociais de retorno, é de extrema importância e ainda não foi incorporada a contento em análises científicas ou na elaboração de políticas. Mas ela fala apenas de uma parte do problema. A outra, o que leva uma sociedade a optar pelo caminho da desconcentração e da diversificação, permanece pouco iluminada. Particularmente no caso brasileiro, cuja herança histórica é justamente marcada pelos elementos opostos a estes, torna-se imperativo conhecer melhor, perante abordagens histórico-comparativas, como determinados territórios evoluíram em condições mais propícias à dinamização econômica, ao bem estar social e à conservação ambiental. Um estudo comparado de territórios rurais visando extrair lições, a partir da especificidade brasileira, sobre as articulações entre instituições, estruturas sociais e meio-ambiente é, portanto, um primeiro desafio. Seu 
tratamento certamente traria importantes constatações sobre a tensão hoje existente entre, de um lado, os ganhos de curto prazo derivados da opção feita pela sociedade brasileira em privilegiar a expansão da agricultura de exportação de commodities, e, de outro, os custos de longo prazo expressos na perda de biodiversidade e na depleção de recursos naturais como solos e águas.

Um segundo tema de pesquisa que emerge das análises aqui contidas é aquele relativo às instituições do desenvolvimento rural. Novamente focalizando o caso brasileiro, é inegável que os anos 90 trouxeram inovações fundamentais, das quais o Pronaf, em vias de completar dez anos, é certamente a melhor expressão, em que pese todas as suas insuficiências. Em contraste, viu-se nesta tese que a emergência de um programa voltado à promoção do desenvolvimento territorial, na presente década, não vem ainda alcançando a mesma repercussão, apesar dos avanços que contém ou insinua. Comparando o relativo sucesso da primeira iniciativa com os impasses vividos pela segunda, torna-se inevitável perguntar as razões que respondem pela emergência e pelo sucesso destas instituições e políticas. Quais as interdependências entre elas e o ambiente institucional no qual elas se inserem e que lhes limita o alcance e o sentido? Qual a dinâmica de interesses capaz de levar à adoção de instituições e políticas mais inovadoras e condizentes com o sentido contemporâneo da ruralidade ? Responder a esta questão é fundamental para que se possa aprender mais sobre as fontes da mudança e, com isso, pensar as possibilidades de criar instrumentos de indução ao desenvolvimento de um amplo espaço geográfico onde vive um contingente nada desprezível de pessoas.

Um terceiro tema, por fim, é aquele relativo à condição de agricultor sob a 'nova ruralidade'. A importância econômica deste segmento social tende claramente a declinar. Mas sua importância social, embora dividindo o protagonismo local com novos segmentos, deve permanecer ainda relevante. Os impasses em torno das reformas das políticas na União Européia e Estados Unidos são a face mais visível disto. No entanto, ser agricultor no limiar do Século XXI guarda muito pouca relação com o que significava a mesma opção duas ou mais gerações atrás. As implicações para a forma de condução da vida eram antes muito mais rígidas do que hoje. Se, antes, ser agricultor implicava numa opção por maior 
isolamento e pelo não acesso a certos confortos tidos como típicos da vida urbana, esta é uma restrição que pesa cada vez menos nos tempos atuais. Se antes bastavam os conhecimentos relativos às lides com a terra, transmitidos informalmente de uma a outra geração, hoje é necessário crescentemente mobilizar mais e novos recursos, introduzir técnicas de produção, de gestão e de acesso a mercados que demandam novas habilidades. O reconhecimento desta situação e das formas pelas quais tais populações vêm conseguindo recriar seus padrões de reprodução social é algo importante não só para atualizar o conhecimento científico perante estes novos conteúdos sociais, das quais as estratégias familiares são a um só tempo resultante e resultado, mas também para se questionar os contornos a partir dos quais são pensadas as iniciativas públicas a elas direcionadas. Para ficar em apenas um exemplo, um grande dilema do debate público brasileiro continua ser a pertinência de um amplo programa de reforma agrária. Mas os termos do debate, tanto da parte dos que reivindicam uma ação nesta direção, como da parte dos que a criticam por obsolescência, permanecem presos a um sentido que é o mesmo há quase um século: uma visão agrária da reforma agrária. As políticas para as famílias de agricultores ou para dilemas históricos, como a questão fundiária, não teriam que ser repensadas à luz do esfacelamento do mundo agrário e da emergência de uma nova ruralidade ?

Por tudo isso, esta tese respondeu afirmativamente à interrogação sobre a existência de um novo momento na evolução do desenvolvimento rural: certamente não é possível compreendê-lo senão em termos territoriais. Mas a resposta relativa a característica do compromisso social em torno do rural foi negativa: embora sob este signo de uma nova ruralidade, não se erigiu, ainda, por completo, um novo compromisso institucional, um compromisso não mais setorial e sim territorial.

Como se vê, os três desafios de compreensão do rural brasileiro que emergem desta tese guardam estreita correspondência com as necessidades históricas do país em repensar seu percurso e suas alternativas de desenvolvimento. Durante muito tempo se imaginou que a industrialização resolveria por si os impasses de nossa formação como nação. Hoje, só o desconhecimento ou a ideologia urbana servem como justificativa para se negar a importância de retomar a expressão "interiorização do desenvolvimento". Não no sentido 
de levar ao Brasil profundo o mesmo estilo de políticas e de investimentos experimentados nos pólos dinâmicos da economia nacional. Mas sim daquilo que Osvaldo Sunkel chamava de 'desarrollo desde dentro'. É impossível imaginar que o país encontrará o caminho do dinamismo com coesão social e conservação ambiental sem encontrar uma solução para o Brasil rural. Um século depois de Euclides da Cunha, talvez seja tempo de reinventar os sertões e enfrentar o emblema: "ali onde isso era, devo vir a me tornar". 


\section{Bibliografia}

ABRAMOVAY, Ricardo (1992). Paradigmas do capitalismo agrário em questão. Campinas/São Paulo: Ed.Unicamp/Hucitec.

ABRAMOVAY, Ricardo (1996). Da força da teoria e da teimosia dos fatos. São Paulo/sp, fotocopiado.

ABRAMOVAY, Ricardo (2000). "O capital social dos territórios - repensando o desenvolvimento rural”. Economia Aplicada, n. 2, Vol. IV: 379-397. São Paulo.

ABRAMOVAY, Ricardo (2001). "Desenvolvimento e instituições - a importância da explicação histórica". In: Arbix, G., Zilbovicius, M., e Abramovay, R. (orgs.). Razões e ficções do desenvolvimento. São Paulo: Edusp.

ABRAMOVAY, Ricardo (2002). Diversificação das economias rurais no Nordeste. Brasília: Relatório de Pesquisa NEAD.

ABRAMOVAY, Ricardo (2003). O futuro das regiões rurais. Porto Alegre: Ed. da UFRGS.

ABRAMOVAY, Ricardo (2005-a). "Entre Deus e o Diabo: mercados e interação humana nas ciências sociais". Tempo Social - Revista de Sociologia da USP, Vol. 16, n. 2, São Paulo: Novembro/2004.

ABRAMOVAY, Ricardo (2005-b). "Representatividade e inovação". Paper apresentado no Seminário Nacional de Desenvolvimento Rural Sustentável. CNDRS, Brasília/DF.

ABRAMOVAY, Ricardo \& VEIGA, José Eli (1998). "Novas instituições para o desenvolvimento rural - o caso do Pronaf." Textos para Discussão, n. 641. Convênio Fipe/Ipea 07/98.

ABRAMOVAY, Ricardo et al. (2003). "Sucessão hereditária e reprodução social da agricultura familiar”. In: Agricultura em São Paulo, 50(1): 11-24. São Paulo/SP.

ACSELRAD, Henri (2004). “As práticas espaciais e o campo dos conflitos ambientais”. In: ACSELRAD, Henri (org). Conflitos ambientais no Brasil. Rio de Janeiro: Relume Dumará.

ADORNO, Theodor (1974/1999). "Introdução à controvérsia sobre o positivismo na sociologia alemã”. In: Adorno - Coleção Os Pensadores, São Paulo: Ed. Abril.

AMABLE, Bruno \& PALOMBARINI, Stefano (2005). L'économie n'est pas une science morale. Paris: Raisons d'Agir. 
ANDERSON, J.L. (1991). Explaining long-term economic change. Cambridge: Cambridge University Press.

ARRIGHI, Giovanni (1997). A ilusão do desenvolvimento. Petrópolis: Ed. Vozes. 2 a .ed.

AYMARD, Maurice (1992). "Autour des Annales - la ville selon Braudel”. IN: SACHS, Ignacy (org). Quelles villes pour quel developpement. Paris: Seuil.

BACKHAUS, Jurgen G. \& MEIJER, Gerrit (2001). "City and country - lessons from european economic tought". IN: American Journal of Economics and Sociology, Vol. 60, N. 1. January/2001.

BAIROCH, Paul (1992). "Cinq milénaires de croissance urbaine”. In: SACHS, Ignacy (org). Quelles villes pour quel devellopement. Paris: Seuil.

BAIROCH, Paul (1993). Economics and world history. Chicago: The University of Chicago Press.

BAIROCH, Paul (199). L'agriculture des pays développés. Paris: Economica.

BAGNASCO, Arnaldo (1977). Tre Italie - la problematica territoriale dello sviluppo italiano. Bologna: Società editrice il Mulino.

BAGNASCO, Arnaldo (1997). "La función de las ciudades en el desarrollo rural: la experiencia italiana”. Política Agrícola. Número especial.

BARKEMA, Alan D. \& DRABENSTOTT, Mark (2000). "How rural America sees its future." The Main Street Economist (Center for the study of rural America - Federal Reserve Bank of Kansas City), December 2000, pp. 1-4

BASILE, Elisabetta \& CECCHI, Claudio Cecchi (1997) . "Beyond the sectors: an analysis of economic defferentiation in rural economy". Working paper n. 29, Dipartimento di economia pubblica - Università di Roma «LaSapienza», Roma , pp. 27.

BECATTINI, G. \& RULLANI, E. (1995). "Système local et marché global. Le district industriel". In: RALLET, Alain \& TORRE, André (coord. ) Économie industrielle et économie spatiale. Paris: Economica.

BECK, Ulrich (1992). Risk society - towards a new modernity. Londres: Sage publications.

BEDUSCHI, L.C. \& ABRAMOVAY, R. (2004). "Desafios para o desenvolvimento das regiões rurais". In: Nova Economia, n. 14(3)p. 35-70, set-dez/2004. Belo Horizonte.

BENKO, Georges \& LIPIETZ, Alain - Eds. (1992). Les régions qui gagnent - districts et réseaux: les nouveaux paradigmes de la geógraphie économique. Paris: PUF. 
BENKO, Georges \& LIPIETZ, Alain - Eds. (2000) La richesse des régions - la nouvelle géographie socio-économique. Paris: PUF.

BID (2005). Politica de Desarrollo Rural. Consultado em www.rimisp.org/bidpoliticarural

BOSERUP, Ester (1987). Evolução agrária e pressão demográfica. São Paulo: Ed.Hucitec/Ed.Polis.

BOURDIEU, Pierre (1990). Droit et passe-droit: le champ des pouvoirs territoriaux et la mise en ouvre des règlements. In: Actes de la recherche en sciences Sociales, n. 81-82, mars 1990, pages 96-96. Paris.

BOURDIEU, Pierre (1999). Les structures sociales de l'économie. Paris. Seuil.

BOURDIEU, Pierre (2000). Science de la science et reflexivité. Paris: INRA.

BOURDIEU, Pierre (2001-a). O poder simbólico. [Capítulo II - Introdução à uma sociologia reflexiva, Capítulo V - A identidade e a representação: elementos para uma reflexão crítica sobre a idéia de região]. Rio de Janeiro: Bertrand Brasil, $4^{a}$. ed.

BOURDIEU, Pierre (2001-b). Meditações pascalianas. Rio de Janeiro: Bertrand Brasil.

BOURDIEU, Pierre (2002). Le bal des célibataires - crise de la société paysanne en Béarn. Paris: Éditions du Seuil.

BRANDENBURG, Alfio (2005). "Do rural tradicional ao rural socioambiental". Paper apresentado no XII Congresso Brasileiro de Sociologia. Belo Horizonte.

BRAUDEL, Fernand (1985). La dynamique du capitalisme. Paris: Flammarion.

BRAUDEL, Fernand (1979/1995). Civilização material, economia e capitalismo. São Paulo: Martins Fontes, 3 Vol.

BROWN, David L. \& CROMARTIE, John B. (2002). "The nature of rurality in post industrial society". Paper prepared for the conference 'New Forms of Urbanization: Conceptualizing and Measuring Human Settlement in the Twenty-first Century', organized by the IUSSP Working Group on Urbanization and held at the Rockefeller Foundation's Study and Conference Center in Bellagio, Italy, 11-15 March 2002. Draft $2 / 15 / 02$

BRUSCO, Sebastiano (1996). "Trust, social capital and local development - some lessons from the experience of the italian districts". In: OCDE (1996). Networks of enterprises and local developement. Paris: OCDE. 
BRYDEN, John et al. (2000). "Differential economic performance in rural areas". Paper presented at the International Conference on European Rural Policy at the Crossroads. UNiversity of Aberdeen, Kings College: The Arkleton Centre for Rural Development Research. June, 29-July, 12000.

BRYDEN, John \& HART, Keith (2001). Dynamics of rural areas (DORA) - the international comparison. The Arkleton Centre for Rural Development Research. November, 2001.

BUARQUE DE HOLANDA, Sérgio (1936/1995). Raízes do Brasil. São Paulo: Cia.das Letras. $26^{\mathrm{a}}$. ed.

BUTTEL, F. \& NEWBY, H. (1980). The rural sociology of the advanced societies critical perspectives. Montclair/London: Allanheld, Osmun Ed.

CANDIDO, Antonio (1964). Os parceiros do Rio Bonito. São Paulo: José Olympio Ed.

CARDOSO, Fernando H. (1980). "O desenvolvimento na berlinda". In: As idéias e seu lugar. Ensaios sobre as teorias do desenvolvimento. Petrópolis/S.Paulo: Ed. Vozes/Cebrap.

CARDOSO, Fernando H. (1995). "Desenvolvimento - o mais político dos temas econômicos". Revista de Economia Política, v. 15, n. 4 (60), out-dez.1995.

CARNEIRO, Maria José (1998). "Ruralidade: novas identidades em construção". Estudos Sociedade e Agricultura, N. 11., outubro/1998. pp. 63-75.

CECCATO, Vânia \& PERSON, Lars O . "Dynamics of rural areas: an assessment of clusters of employment in Sweden." Journal of Rural Studies, vol 18 (2002), pp. 49-63

CECCHI, Claudio (1999). "How to be rural in late modernity: process, project and discourse". European Society for Rural Sociology, XVIII Congress, Lund, Sweden, 24-28 August 1999. Working Group 4. Social exclusion in rural areas. Dipartimento di Economia pubblica, Università di Roma «La Sapienza».

CECCHI, Claudio (2002). "Il sistema locale come strumento di analisi della ruralità postfordista". in Mezzogiorno rurale - Risorse endogene e sviluppo: il caso della Basilicata, a cura di S. Vellante, Donzelli, Roma, 2002: pp. 183-206

CEPAL; FAO; RIMISP (2003). "La pobreza rural en América Latina: lecciones para una reorientación de las políticas". Série Seminários e Conferências, n. 27. Santiago de Chile.

CHAMPAGNE, Patrick (2002). L'héritage refusé - la crise de la reproduction sociale de la paysannerie française - 1950-2000. Paris: Éditions du Seuil.

CHAMPAGNE, Patrick \& CHRISTIN, Olivier (2004). Mouvements d'une pensée Pierre Bourdieu. Paris: Bordas. 
COMISSÃO BRUNDTLAND (1985). Nosso futuro comum. Editora FGV, 1987.

CORREA, Edelmira P. \& SUMPSI, José Maria - coords. (2001). Políticas, instrumentos y experiencias de desarrollo rural en America Latina y la Unión Europea. Madri: AECI/Fodepal.

COULOMB, Pierre (1991). "Du secteur au territoire - vers um nouveau modèle sóciopolitique". Pour, 130/131: 21-28, Paris.

DALY, Herman (1996). Beyond growth. Boston: Beacon Ed.

DASGUPTA, Partha (2001). Human well-being and the natural environment. Oxford University Press.

DATAR (2001). Réseaux d'entreprises et territoires - regards sur les systèmes productifs locaux. Paris: La documentation française.

DAVIDSON, Osha G. (1996). Broken heartland - the rise of America's Rural ghetto. University of Iowa Press.

DE JANVRY, Alain. The agrarian question and reformism in Latin América. The John Hopkins University Press.

DE JANVRY, Alain \& SADOULET, E. (2001). "Income strategies among rural households in México: the role of off-farm activities", World Development, Vol. 29 (3), pp.468-480.

DEL TORO, Victor M.C. (2004). "Alcances de la ley de desarrollo rural sustentable en Mexico". Taller Propuestas para el Desarrollo Rural y la Producción Agropecuaria. SAGPYA-Banco Mundial y FIDA-BID. Buenos Aires.

DIAMOND, Jared (2002). Armas, germes e aço - os destinos das sociedades humanas. Rio de Janeiro: Ed. Record. $3^{\text {a }}$. edição.

DIAMOND, Jared (2005). Colapso - como as sociedades escolhem o fracasso ou o sucesso. Rio de Janeiro: Ed. Record.

DIRVEN, Martine (2004). Alcanzando las metas del milênio - uma mirada hacia la pobreza rural y agricola. Serie Desarrollo Productivo, n. 146. Cepal. Santiago de Chile.

DOMINGUES, José M. (2000). “A cidade: racionalização e liberdade”. In: Souza, Jessé. (org.). A atualidade de Max Weber. Brasília: Ed. UnB.

DOREL, Gerard (1985). Agriculture et grandes entreprises aux Etats-Unis. Paris: Economica. 
DUBY, Georges (1973). "L'urbanisation dans 1'histoire”. In: Études Rurales, n. 49-50, Janvier-Juin. pp. 10-14.

ECHEVERRIA, Ruben - Ed. (2001). Development of rural economies. BID, Washington, D.C.

EHLERS, Eduardo (2004). Determinantes da recuperação da Mata Atlântica no Estado de São Paulo, Tese de Doutorado, Procam/USP.

ELIAS, Norbert (1970/1991). Qu'est-ce que la sociologie ? Paris: Ed. de 1'Aube.

ELLIS, Frank (1988). Peasant economics - farm household and agrarian development. Cambridge University Press.

ESCOBAL, Javier (2002). Nuevas instituciones para el desarrollo agricola y rural en America Latina y Caribe. CUREMIS II. FAO.

FAO (2004). Una propuesta para el desarrollo rural - Dessarrollo Territorial Participativo y Negociado (DTPN). Grupo de Trabajo SDA.

FAO/INCRA (1994). Diretrizes de política agrária e desenvolvimento sustentável. Relatório final do Projeto UTF/BRA/036. Novembro de 1994.

FAVARETO, Arilson; MAGALHÃES, Reginaldo; BITTENCOURT, Gerson. (2002). "Dinâmicas demográficas e desenvolvimento - apontamentos a partir de seis municípios do Nordeste brasileiro". Paper apresentado no XI Congresso da Associação Latinoamericana de Sociologia Rural. Porto Alegre. .

FAVARETO, Arilson (2004-a). "Agricultores, trabalhadores - os trinta anos do novo sindicalismo rural e a representação política da agricultura familiar no Brasil". Paper apresentado no XXVIII Encontro Nacional da Anpocs. Caxambu/MG.

FAVARETO, Arilson (2004-b). "Empreendedorismo e dinamização dos territórios de baixa densidade empresarial - uma abordagem sociológica e econômica". Paper apresentado no XLII Congresso da Sociedade Brasileira de Economia e Sociologia Rural. Cuiabá/MT, Julho de 2004.

FAVARETO, Arilson \& DEMARCO, Diogo (2004-c). "Entre o capital social e o bloqueio institucional - uma avaliação dos CMDR em cinco estados brasileiros". In: SCHNEIDER, S.; MORUZZI MARQUES, P.; KUNRATH SILVA, M. (2004). Políticas públicas e participação social no Brasil Rural. Porto Alegre: Ed.Ufrgs.

FAVARETO, Arilson (2005-a). “As estruturas sociais e a economia - há uma convergência entre abordagens econômicas e sociológicas contemporâneas ?’. Paper apresentado no XXIX Encontro Nacional da Anpocs. Caxambu/MG 
FAVARETO, Arilson (2005-b). "Do Pronaf ao desenvolvimento territorial - elementos para uma crítica das instituições e políticas para o Brasil rural". Paper apresentado no XII Congresso Brasileiro de Sociologia, Belo Horizonte/MG.

FERNANDES, Florestan (1959-a). Mudanças sociais no Brasil. São Paulo/Rio de Janeiro: Difel.

FERNANDES, Florestan (1959-b). Fundamentos empíricos da explicação sociológica. São Paulo: Cia. Editora Nacional.

FLIGSTEIN, Neil (2001) The architecture of the markets. Princeton University Press.

FRIEDLAND, William H. (1982). "The end of rural society and the future of rural sociology”. Rural Sociology, 47 (4): 598-608.

FRIEDLAND, William H. (2002). "Agriculture and rurality - beginning the "final separation”? In: Rural sociology 67 (3), pp.350-371.

FROUWS, J. "The Contested Redefinition of the Countryside. An Analysis of Rural Discourses in The Netherlands". Sociologia Ruralis, April 1998, vol. 38, n. 1, pp. 54-68.

FUJITA, M.; KRUGMAN, P. e VENABLES, A . (1999). The spatial economy. Cambridge, MA: MIT Press.

FURTADO, Celso (1974). O mito do desenvolvimento econômico. São Paulo.

GALSTON, William A. \& BAEHLER, Karen J. (1995). Rural development in the United States - connecting theory, practice and posibilities. Washington-DC/CoveloCalifórnia: Island Press.

GARCIA, Alex Barril (2002). Desarrollo rural - concepto, institucinalidad y politicas en el 2001. Santiago de Chile: IICA.

GARCIA Jr. Afrânio R. (2003). "A sociologia rural no Brasil: entre escravos do passado e parceiros do futuro". Sociologias. ano 5., n. 10., julho/dezembro/2003. Porto Alegre.

GARCIA Jr. Afrânio R. \& GRYNSZPAN, Mario (2002). "Veredas da questão agrária e enigmas do Grande Sertão". In: MICELI, Sérgio (org.). O que ler na ciência social brasileira Vol. IV (1970-2002). São Paulo/Brasilia: Anpocs-Ed. Sumaré/CAPES.

GARCIA-PARPET, Marie-France (2003). "A construção social de um mercado perfeito o caso de Fontaines-en-sologne". In: Revista Estudos Sociedade e Agricultura. N. 20, Abril/2003.

GARCIA-PARPET, Marie-France (2003). "Dispositions économiques et stratégies de reconversion. L'exemple de la nouvelle viticulture" In: Ruralia, n. 7. 2000. p. 129-151. 
GAROFOLI (1997). "Desarrollo rural e industrialización difusa - aprendiendo de la experiencia italiana”. Politica Agricola. Número especial. 1997.

GERMER, Claus (1996). A irrelevância prática da agricultura familiar para o emprego agrícola. Curutiba/PR. Fotocopiado.

GIDDENS, A.; BECK, U.; LASH, S. (1997). Modernização reflexiva - política, tradição e estética na ordem social moderna. São Paulo: Ed. Unesp.

GEORGESCU-ROEGEN, Nicholas (1973). The entropy law and the economic problem. In: DALY, Herman (1973). Toward a steady-state economy. San Francisco: Freeman.

GOODMAN, David \& REDCLIFT (1991). Refashioning nature - food, ecology and culture. London: Routledge.

GRAZIANO DA SILVA, José (1999). O novo rural brasileiro. Campinas: Unicamp/IE. Coleção Pesquisas, n. 1.

GRAZIANO DA SILVA, José (2001-a). "Quem precisa de uma estratégia de desenvolvimento ?” Nead. Série Textos para Discussão, n.2 . Brasília/DF, pp. 5-51.

GRAZIANO DA SILVA, José (2001-b). "Velhos e novos mitos do rural brasileiro". In: Estudos Avançados - Dossiê Desenvolvimento Rural. Vol. 15, n. 43, Setembro/Dezembro2001

GROSSMAN, Gene M. \& KRUEGER, Alan B. (1995). "Economic growth and the environment". In: Quarterly Journal of Economics, Vol. 110 (2), p. 353-377. May/1995.

GUIVANT, Julia S. (1998). "A trajetória das análises de risco - da periferia ao centro da teorial social”. IN: $\boldsymbol{B I B}$, n. $46,2^{\circ}$. semestre de 1998, p. 3-38.

GUYOT, Sylvain (2005). Essai de sociologie territoriale sud-africaine, EspaceTemps.net, www.espacestemps.net/document1317.html

HAESBAERT, Rogério (2004). O mito da desterritorialização: do "fim" dos territórios à multiterritorialidade. Rio de Janeiro: Bertrand Brasil.

HALFACREE, Keith (2002). "Re-thinking 'rurality'. Paper prepared for the conference 'New Forms of Urbanization: Conceptualizing and Measuring Human Settlement in the Twenty-first Century', organized by the IUSSP Working Group on Urbanization and held at the Rockefeller Foundation's Study and Conference Center in Bellagio, Italy, 11-15 March 2002.

HARRINGTON V. \& O’DONOGHUE D. (1998) "Rurality in England and Wales 1991: A Replication and Extension of the 1981 Rurality Index." Sociologia Ruralis, August 1998, vol. 38, n. 2, pp. 178-203 
HEATHER, Barbara et al. (2005) "Women's gendered identities and the restructuring of rural Alberta”. Sociologia Ruralis 45 (1-2), 86-97

HEGEDUS, Andras (1986). “A questão agrária”. In: HOBSBAWN, Eric. História do Marxismo, V. 6. São Paulo: Paz e Terra.

HERVIEU, Bertrand \& VIARD Jean (1996/2001). Au bonheur des campagnes. Paris: Ed. Éditions de l'Aube.

HODGSON, Geoffrey M. (1993). Economics and evolution - bringing life back into economics. The University of Michigan Press.

HODGSON, Geoffrey, M. (2004). "Veblen and Darwinism". International Review of Sociology, Vopl. 14, n. 3.

HOPKINS, Raúl (2001). "La agricultura en America Latina, Europa Latina y el rol de la FIDA". In: CORREA, Edelmira P. \& SUMPSI, José Maria (coords.). Políticas, instrumentos y experiencias de desarrollo rural en America Latina y Europa. Madrid: Fodepal/Ministério de Agricultura Pesca y Alimentación/AECI.

HORKHEIMER, M. \& ADORNO, T. (1977). "Sociedade”. In: FORACCHI, Marialice M. \& MARTIS, José de Souza (orgs). Sociologia e sociedade - leituras de introdução à Sociologia. Rio de Janeiro: LTC Ed.

HOUTZAGER, Peter \& MOORE, Mick - eds. (2005). Changing paths - international development and the new politics of inclusion. The University of Michigan Press.

IBGE/IPEA/Nesur-IE/unicamp (1999). Caracterização e tendencias da rede urbana do Brasil. Campinas: IE/Unicamp. 2 vol.

INCRA (1998). Agricultura familiar, reforma agrária e desenvolvimento local para um Novo Mundo Rural - Política de Desenvolvimento Rural com base na expansão da agricultura familiar e sua inserção no mercado. Brasília/DF.

INSEE/INRA (1998). Les campagnes et leurs villes - contours et caractères. Paris.

JACOBS, Jane (1969). The economy of cities. New York: Random House.

JACOBS, Jane (1984). Cities and the wealth of nations. London: Penguin Books.

JACOBS, Jane (2000). Morte e vida das grandes cidades. São Paulo: Martins Fontes.

JACOBS, Jane (2001). A natureza das economias. São Paulo: Beca Prod. Culturais.

JEAN, Bruno (1997). Territoires d'avenir - pour une sociologie de la ruralité. PUQ. 
JOLliVET, M. (1992). Sciences de la nature, sciences de la societé - les passeurs de frontières. Paris: CNRS Ed.

JOLliVET, M. (1998). “A 'vocação atual da sociologia rural”. Estudos Sociedade $\boldsymbol{e}$ Agricultura. N. 11, outubro/1998. pp. 5-25.

JOLLIVET, M. (2001). Pour une science sociale à travers champs - paysannerie, ruralité, capitalisme (France, XXe. Siècle).Éditions Arguments.

JOLliveT, M. \& GERVAIS, M. (1976). Histoire de la France rurale, Tome 4 - La fin de la France paysanne: de 1914 à nos jours. Paris: Seuil.

JOLLIVET, M. \& EIZNER, N. - dir. (1996). L'Europe et ses campagnes. Paris: Presses de Sciences Po.

JONES, Charles (2000). Introdução à teoria do crescimento econômico. Rio de Janeiro: Ed. Campus.

JULLIARD, E. (1973). “Urbanisation des campagnes". In: Études Rurales, n. 49-50, Janvier-Juin. pp. 5-10.

KAGEYAMA, Angela. \& BERGAMASCO, Sonia M. P. (1990). "A estrutura da produção no campo em 1980”. Perspectivas, São Paulo/SP, v. 12, p. 55-72, 1990

KAYSER, Bernard (1990). La renaissance rurale - sociologie des campagnes du monde occidental. Paris: Armand Colin.

KAYSER, Bernard (1993). Naissance de nouvelles campagnes. Paris: Datar/Ed. De 1 'Aube.

KOBRICH, C., VILlanUEVA, L., DIRVEN, M. (2004). Pobreza rural y agricola: entre los atractivos, las oportuidades y las políticas - una mirada hacia Chile. Cepal. Série Desarrollo Productivo, n. 144. Santiago de Chile, Enero de 2004.

KUHN, Thomas (1962/1987). A estrutura das revoluções científicas. São Paulo: Perspectiva.

KUHN, Thomas (1965/1979). "Lógica da descoberta ou psicologia da pesquisa ?". In: LAKATOS, I. \& MUSGRAVE, A. (orgs.). A crítica e o desenvolvimento do conhecimento. pp. 5-62, São Paulo: Cultrix/Edusp.

KUHN, Thomas (1970). The structure of scientific revolutions. The University of Chicago, $2^{\mathrm{a}}$. ed.

LAMARCHE, Hugues (1993/1998). A agricultura familiar, Vol. I e II. Campinas: Ed. da Unicamp. 
LASH, Scott (1995). "A reflexividade e seus duplos - estrutura, estética e comunidade". In: GIDDENS, A ., BECK, U., LASH, S. (1997) Modernização reflexiva. São Paulo: Ed. Unesp.

LATOUR, Bruno (1999). Politiques de la nature - comment faire entrer les sciences em démocratie. Paris: La Découverte.

LÉBARON, Fréderic (2000). La croyance économique - les économistes entre science et politique. Paris: Seuil.

LEFEBVRE, Henri (1970/2002). A revolução urbana. Belo Horizonte: Ed. da UFMG.

LEFEBVRE, Henri (1974/1995). The production of space. Oxford: Blackwell.

LEFF, Enrique (2001). Epistemologia ambiental. São Paulo: Cortez.

LEFORT, Isabelle (1997). Crises et mutations des espaces ruraux dans le pays anciennement industrialisés. Paris: Economica.

LENCIONI, Sandra (2003). Região e geografia. São Paulo: Edusp.

LÉVI-STRAUSS, Claude (1950/2003). !Introdução à Sociologia e Antropologia de Marcell Mauss". In: MAUSS, Marcel. Antropologia e Sociologia. São Paulo: Cosac \& Naif.

MACEDO, Bernardo Gouthier (2001). "A concepção de história em Douglass North e na economia do desenvolvimento". IN: II Seminário Brasileiro da Nova Economia Institucional. Campinas.

LOUREIRO, Maria Rita (1995). "L'Ascension Des Economistes au Bresil”. Actes de La Recherche En Sciences Sociales, 1995

MAGALHÃES, Reginaldo (2005). Economia, natureza e cultura: uma visão histórica e interdisciplinar dos sertanejos, dos mercados e das organizações no sertão da Bahia. Dissertação de Mestrado, Procam/USP

MAGNAGHI, Alberto (2005). The urban village. London: Zed Books.

MAILLAT, Dennis (1995). "Millieux innovateurs et dynamique territoriale"; In: RALLET, Alain \& TORRE, Andre. Économie industrielle et économie spatiale. Paris: Economica.

MALAGODI, Edgard (1993). Formas e limites do capitalismo agrário - uma leitura crítica de Smith, Ricardo e Marx. São Paulo, 1993. Tese. PUC-São Paulo.

MANKIW, N.G. (2001). Introdução à economia - princípios de micro e macroeconomia. Rio de Janeiro: Ed. Campus. 
MANTZAVINOS, C.; NORTH, Douglas C.; SHARIQ, Syed (2003). Learning, institutions and economic performance. Max Planck Institute for Research on Collective Goods, consultado em www.ssm.com/abstract=510902.

MARQUES, Maria Inez M. (2002). O conceito de espaço rural em questão. In: Terra Livre, Ano 18, n. 19, p.95-112, jul-dez/2002, São Paulo.

MARSDEN, Terry (1998). "New rural territories: regulating the differentiated rural spaces”. Journal of Rural Studies, vol. 14, n. 1, 1998, pp. 107-117.

MARSDEN, Terry (1999). "Rural Futures: The Consumption Countryside and its Regulation” Sociologia Ruralis, October 1999, vol. 39, no. 4, pp. 501-526.

MARTIN, Ron. \& SUNLEY, Peter (2001). "Deconstructing clusters - chaotic concept or policy panacea?" In: Journal of Economic Geography, Vol. 3. N. 1, January 2003.

MARTINS, José de Souza (1986). "As idéias-unidade da sociologia". In: MARTINS, J.S. (org.). Introdução crítica à sociologia rural. 2a . ed. São Paulo: Ed. Hucitec.

. “Conservadorismo e sociologia". In: MARTINS, J.S. (org.). Introdução crítica à sociologia rural. 2a . ed. São Paulo: Ed. Hucitec

MARTINS, José de Souza (2001). "O futuro da sociologia rural e sua contribuição para a qualidade de vida rural”. In: Estudos Avançados - Dossiê Desenvolvimento Rural. Vol. 15, n. 43, Setembro/Dezembro-2001.

MARX, Karl (1964). Formações econômicas pré-capitalistas. São Paulo: Ed. Paz e Terra.

MARX, Karl \& ENGELS, F. (1989). A ideologia alemã. São Paulo: Ed. Hucitec.

MAUSS, Marcel (1950/2003). Sociologia e antropologia. São Paulo: Cosac \& Naify.

MAYR, Ernst (1997). This is biology - the science of the living world. Cambridfe/London: The Belknap Press of Harvard University Press.

MAZOYER, Marcel (2001). Protéger la paysannerie pauvre dans un contexte de mondialisation. FAO.

MAZOYER, Marcel \& ROUDART, Laurance (1997/2002). Histoire des agricultures du monde - du néolithique à la crise contemporaine. Paris: Éditions du Seuil.

MCcGRANAHAN, DAvid (1999). Natural amenities drive rural population change. Agricultural Economic Report 781. USDA-ERS, Washington.D.C.

MEARDON, Stephen (2001). "Modeling agglomeration and dispersion in city and country - Gunnar Myrdal, François Perroux, and the New Economic Geography". In: American Journal of Economics and Sociology, Vol. 60, n. 1, January/2001. 
MEDEIROS, Leonilde S. \& LEITE, Sergio - orgs. (2004). Assentamentos rurais mudança social e dinâmica regional. Rio de Janeiro: Mauad.

MENDRAS, Henri (1976). Societés paysannes. Paris: Armand Colin.

MENDRAS, Henri (1984). La fin des paysans - suive d'une refléxion sur la fin de paysans vint ans aprés. Paris: Actes Sud.

MERTON, Robert K. (1996). On social structure and science. Chicago: The University of Chicago Press.

MEYER-STAMER, Jorg (2004). Governance and territorial development - policy, politics and polity in local economic development. Mesopartner Working Paper, 07/2004. www.mesopartner.com .

MEYER-STAMER, Jorg (2004). "Estratégias de desenvolvimento local e regional clusters, política de localização e competitividade sistêmica". Policy Paper, n. 28. setembro, 2001. Ildes/FES.

MIDMORE, Peter. (1999). "Globalisation and the rural economy". Edited version of the text of a public lecture given at the University of Wales, Aberystwyth, December 1999. School of Management and Business, University of Wales, Aberystwyth, Wales, UK.

MINGIONE, Enzo \& PUGLIESE, Enrico. (1987). "A difícil delimitação do "urbano" e do "rural" - alguns exemplos e implicações teóricas". Revista Crítica de Ciências Sociais, n. 22, Abril/1987.

MITCHELL, Clare J. E. (1998). "Entrepreneuralism, commodification and creative destruction: a model of post-modern community development". Journal of Rural Studies, vol. 14, n. 3, 1998, pp. 273-286

MITCHELL, Clare J.A. (2004). "Making sense of counterurbanization”, Journal of Rural Studies, vol. 20 (2004) pp. 15-34

MORAES FILHO, Evaristo org. (1983). Simmel - Coleção Grandes Cientistas Sociais. São Paulo. Ed. Ática.

MONTE-MOR, Roberto L.M. (2003). "Outras fronteiras: novas espacialidades na urbanização brasileira. In: CASTRIOTA, Leonardo B. - org. Urbanização brasileira: redescobertas. Belo Horizonte: Ed. C/Arte.

MORMONT, Marc (2000). À la recherche des especificités rurales. Fotocopiado.

NAVARRO, Zander (2003). "Desenvolvimento rural no Brasil - os limites do passado e os caminhos do futuro". Estudos Avançados - Dossiê Desenvolvimento Rural. Vol. 15, n. 43, Setembro/Dezembro-2001. 
NISBET, Robert (1977). "Comunidade”. In: FORACCHI, Marialice M. \& MARTIS, José de Souza (orgs). Sociologia e sociedade - leituras de introdução à Sociologia. Rio de Janeiro: LTC Ed.

NISBET, Robert (1985). História da idéia de progresso. Brasília: Ed. UnB.

NORGAARD, Rochard B. (1996). Development betrayed - the end of progress and a coevolutionary revisioning of the future. London/N.York: Routledge.

NORTH, Douglass (1981). Structure and change in economic history. N. York/London: W.W.Norton \& Company.

NORTH, Douglass (1990). Institutions, institutional change and economic performance. Cambridge University Press.

NORTH, Douglass (2005). Learning, institutions and economic performance. Princeton University Press.

NORTH, Douglass \& THOMAS, Robert Paul (1973). The rise of the Western World. A new economic history. Cambridge University Press.

OCDE (1993). What future for our contryside ? A rural development policy. Paris: OCDE.

OCDE (1995). Creating employment for rural development - new policy approaches. Paris; OCDE.

OCDE (1996). Indicateurs territoriaux de l'emploi - le point sur le devéloppement rural. Paris: OCDE.

OCDE (2003). The future of rural policy - from sectoral to place-based policies in rural areas. Paris: OCDE.

OSTROM, Elinor (1990). Governing the commons - the evolution of institutions for collective action. Cambridge: Cambridge University Press.

OUGHTON, E. ; Wheelock J. \& Baines S. (2003). "Micro-businesses and Social Inclusion in Rural Households: a Comparative Analysis", Sociologia Ruralis, October 2003, vol. 43, no. 4, pp. 331-348.

PAULANI, Leda (2005). "Economia e Retórica: o capítulo brasileiro". Revista de Economia Política.

PECQUER, Bernard (2000). Le développement local - pour une économie des territories. Paris: Syros. 
PIERSON, Paul (2004). Politics in time - history, institutions and social analysys. Princeton University Press.

PIERUCCI, Antônio Flávio (2003). O desencantamento do mundo - todos os passos do conceito em Max Weber. São Paulo: Editora 34.

PIRES, André (2004). De rocinha aos enclaves: figurações do rural em Vinhedo, SP. Tese de Doutorado. IFCH/UNicamp. Campinas.

PONTING, Cliv (1995). Uma história verde do mundo. Rio de Janeiro: Civilização Brasileira.

POPPER, Karl (1959/1993). A lógica da pesquisa científica. São Paulo: Cultrix.

POPPER, Karl (1978). “A lógica das ciências sociais”. In: POPPER, Karl. Lógica das ciências sociais . Brasília: Ed. UnB.

POPPER, Karl (1965/1987). “A ciência normal e seus perigos”. In: LAKATOS, I. \& MUSGRAVE, A. (orgs.). A crítica e o desenvolvimento do conhecimento. São Paulo: Cultrix/Edusp.

Projeto CUT/CONTAG (1998). Desenvolvimento e sindicalismo rural no Brasil. São Paulo/Brasília.

PRZEWORSKI, A. (2003). "Institutions Matter?”. Paper presented at the Seminar Institutions, Behaviour and Outcomes. Cebrap, São Paulo.

PNUD (1999). Relatório sobre o Desenvolvimento Humano. www.pnud.org.br

PNUMA (2002). Panorama ambiental global. www.inep.org/GEO/geo3/index.htm

PUTNAM, Robert (1996). Comunidade e democracia - a experiência da Itália moderna. Rio de Janeiro: Ed. FGV.

QUEIROZ, Maria Isaura P. (1979). Do rural e do urbano no Brasil. In: SZMRECSÁNY, Tamás \& QUEDA, Oriowaldo (orgs.). Vida rural e mudança social. São Paulo: Ed. Nacional.

RAEDEKE, Andrew H. et al. (2003). "Farmers, the practice of farming and the future of agroforestry - an aplication of Bourdieu's concept of field and habitus". In: Rural Sociology, 68(1), pp. 64-86.

RAHNEMA, Majid \& BAWTREE, Victoria - eds. (1997). The post-development reader. London: ZED Books.

RAMBAUD, P. (1973). "Village et urbanisation. Problèmes sociologiques". In: Études Rurales, n. 49-50, Janvier-Juin. 1973. 
RAUD, Cécile (1999). Indústria, território e meio-ambiente no Brasil - perspectivas da industrialização descentralizada a partir da análise da experiência catarinense. Florianópolis/Blumenau: Ed. FURB/ Ed. UFSC.

RAY, Christopher (2000). "The EU Leader Programme - rural development laboratory". In: Sociologia Ruralis, Vol. 40, N. 2, April/2000.

RAY, Christopher (2001-a). "Transnational co-operation between rural areas: elements of a political economy of EU rural development." Sociologia Ruralis, vol. 41, n.3, July 2001, pp. 279-295.

RAY, Christopher (2001-b). Further ideas about local rural development - trade, production and cultural capital. Working Paper, 49. www.ncl.ac.ik/cre/publications

RAY, Christopher (2002). "A mode of production for fragile rural economies: the territorial accumulation of forms of capital." - Guest Editorial - Journal of Rural Studies, vo. 18 (2002), pp.225-231

REDCLIFT, Michael (1993). Sustainable development - concepts, contradictions and conflicts. In: ALLEN, P. (1993). Food for the future - conditions and contradictions of sistainability. New York: John Wiley \& Sons Inc.

RENKOW M. (2003), Cities, Towns and the Rural Non-farm Economy in Haggblade, S. Hazell, P. and Reardon, T. Strategies For Stimulating Growth of the Rural Non-farm Economy in Developing Countries, Baltimore: John Hopkins University Press.

RICCI, Giancarlo (2005). As cidades de Freud. Rio de Janeiro: Jorge Zahar Ed.

RICHARDSON, Tim. (2000). "Discourses of rurality in EU spatial policy: The European Spatial Development Perspective.”Sociologia Ruralis, vo. 40, n. 1, Jan. 2000, pp. 53-71

RIMISP (2004). Seminário-Taller Transformación Productiva e Institucional en el Mundo Rural de Argentina - Síntesis de las Ponencias y del Debate. Buenos Aires: Rimisp.CD.ROM

RINGER, Fritz (2004). Metodologia de Max Weber - unificação das ciências sociais e culturais. São Paulo: Edusp.

RIST, Gilbert (2001). Le développement: histoire d'une croyance occidentale. Paris: Presses de Sciences Po.

RIVERO, Oswaldo (2002). O mito do desenvolvimento. Os países inviáveis no século XXI. Petrópolis: Ed. Vozes. 
RODWIN, Lloyd \& Schon, Donald A. - Eds. (2000). Rethinking the development experience - essays provoked by the work of Albert $O$. Hirschman. Washington/Cambridge: The Brookings Institution/The Lincoln Institute of Land Policy.

ROMERO, José Luis (2004). América Latina - as cidades e as idéias. Rio de Janeiro: Ed. UFRJ.

ROMEIRO, Ademar R. (2000). "Sustainable development and institucional change - the role of altruistic behavior". IN: Textos para discussão. IE/Unicamp. n. 97, jun/2000.

ROMEIRO, Ademar R. (2001). "Economia ou economia política da sustentabilidade ? ". IN: Textos para Discussão. IE/Unicamp. n. 102, Set/2001.

ROSTOW, W.W. (1960). The stages of economic growth. Cambridge: Cambridge University Press.

RULFO, Juan (2004). Pedro Páramo \& Chão em Chamas. Rio de Janeiro: Ed. Record.

SACHS, Ignacy (1980). Stratégies de I'Éco-développement. Paris: Les Éditions Ouvrières.

SACHS, Ignacy (2001)."Brasil rural - da redescoberta à reinvenção". In: Estudos Avançados - Dossiê Desenvolvimento Rural_.Vol. 15, n. 43, Setembro/Dezembro-2001

SACHS, Ignacy (2004-a). Remnants of the past or architects of the future ? Human development, decent work and small producers in Brazil. EHESS/Sebrae-Seminário IPE/USP.

SACHS, Ignacy (2004-b). Desenvolvimento e cultura. Desenvolvimento da cultura cultura do desenvolvimento. Paper apresentado no Seminários FEA/USP. Fotocopiado.

SACHS, Ignacy (2004-c). Desenvolvimento: includente, sustentável, sustentado. Rio de Janeiro: Garamond.

SANTOS, Milton (1999). A natureza do espaço - técnica e tempo, razão e emoção. São Paulo: Ed.Hucitec.

SANTOS, Milton (1996). A urbanização brasileira. São Paulo: Ed. Hucitec.

SARACENO, Elena (1996). "O conceito de ruralidade - problemas de definição em escala européia”. Paper apresentado no Programa de Seminários INEA sobre desenvolvimento nas áreas rurais - Métodos de análise e políticas de intervenção. Roma, Outubro de 1996. Traduzido do original italiano por Angela Kageyama.

SARACENO, Elena (1997). 'Urban-rural linkages, internal diversification and external integration - a european experience'. Revista Politica Agricola, 1997. 
SCHATTAN, V.; FAVARETO, A.; GALVANEZZI, C.; MENINO, F. (2005). Barragem de Tijuco Alto - território, recursos naturais e direitos das comunidades tradicionais em debate nos fóruns participativos do Vale do Ribeira. Relatório de Pesquisa Cebrap/Rimisp.

SCHEJTMAN, Alexander \& BERDEGUÉ, Julio (2003). “Desarrollo territorial rural”. In: ECHEVERIA, R. - Ed. . Desarrollo territorial rural en América Latina y el Caribe: manejo sostenible de recursos naturales, acesso a tierras y finanzas rurales.BID. Washington, D.C.

SCHNEIDER, Sérgio (1996). "Da crise da sociologia rural à emergência da sociologia da agricultura: reflexões a partir da experiência norte-americana". Paper apresentado no Workshop de Economia Política da Agricultura. Campinas, IE/Unicamp.

SCHNEIDER, Sérgio (2003). "A abordagem territorial do desenvolvimento rural e suas articulações externas". Paper apresentado no I Fórum Internacional Território, Desenvolvimento Rural e Democracia, Fortaleza/CE, novembro de 2003.

SCHNEIDER, Sérgio; MATTEI, Lauro; CAZELLA, Ademir (2004). "Histórico, caracterização e dinâmica recente do Pronaf." In: SCHNEIDER, et al. orgs. Políticas públicas e participação social no Brasil rural. Porto Alegre: Ed. UFRGS.

SEN, Amartya (1992/2000). Repenser l'inegalité. Paris: Seuil.

SEN, Amartya (2000). Desenvolvimento como liberdade. São Paulo. Cia. das Letras.

SERAGELDIN, Ismail \& STEEDS, David eds. (1997). Rural well-being - From vision to action. Proceedings of the Fourth Annual Bank Conference on Environmentally Sustainable Development. Environmentally and Socially Sustainable Development Proceedings Series, n. 15. The World Bank, Washington, DC.

SERVOLIN, Claude (1989). L'agriculture moderne. Paris: Éditions du Seuil.

SFORZI, Fabio (1996). "Local systems of small and medium-sized firms and industrial changes". In: OCDE. Networks of enterprises and local development. Paris: 1996.

SHEPHERD, Andrew (1998). Sustainable rural development. London/N.York: Macmillan Press/St.Martin Press.

SHUCKSMITH, M.; Chapman P. (1998). "Rural Development and Social Exclusion"Sociologia Ruralis, August 1998, vol. 38, no. 2, pp. 225-242

SCHUCKSMITH, Mark. (2000). "Endogenous development, social capital and social inclusion: perspectives from LEADER in the UK. Sociologia Ruralis, vol. 40, n. 2, April 2000, pp. 208-218 
SIMMEL, Georg. (1983). Sociabilidade - um exemplo de sociologia pura ou formal. In: MORAES FILHO, Evaristo org. (1983). Simmel - Coleção Grandes Cientistas Sociais. São Paulo. Ed. Ática.

SOARES, Adriano C. O . \& SAUER, Sérgio (1998). "A estratégia do BID e do Banco Mundial para o campo brasileiro". In: VIANNA, Aurélio. A estratégia dos bancos multilaterais para o Brasil. Brasília: Rede Brasil.

SOROKIN, P.; ZIMMERMAN, C.; GALPIN, C. (1986). Diferenças fundamentais entre o mundo rural e o urbano". In: MARTINS, J.S. (org.). Introdução crítica à sociologia rural. São Paulo: Hucitec. 1986.

SUNKEL, Oswaldo (1991). El desarrollo desde dentro. Um enfoque neoestructuralista para la América Latina. Cidade do México: FCE.

SWEDBERG, Richard (2005). Max Weber e a idéia de sociologia econômica. Rio de Janeiro: Ed. UFRJ.

TERLUIN, Ida J. (2003). "Differences in economic development in rural regions of advanced countries - an overview and critical analysis of theories'. In: Journal of rural studies, 19, p. 327-344.

TERLUIN, Ida J. \& Jaap H. Post (2003). "Differences in economic development in rural regions of advanced countries: a review of theories". Paper for the International Conference of the Regional Studies Association 'Reinventing regions in the global economy', Pisa, April 12-15, 2003.

THE WORLD BANK (1997). Rural well-being - From vision to action. Proceedings of the Fourth Annual Bank Conference on Environmentally Sustainable Development. Washington, DC.

THE WORLD BANK (2001-a). Plan de Acción para el Desarrollo Rural en America Latina y el Caribe - un insumo para la Revisión de la Visión a la Acción. Resumen del Informe. Marzo, 2001.

THE WORLD BANK (2001-b). Rural development strategy and action plan for the Latin America and the Caribbean Region. Vol. 1. Main Report. 2001.

THE WORLD BANK (2005). Beyond the city - the rural contribution to development. Report. Consultado em www.worldbank.org .

THOMAS, Keith (2001). O homem e o mundo natural - mudanças de atitude em relação às plantas e aos animais. São Paulo: Cia. Das Letras.

THOMSIN, Laurence (2001). "Un concept pour le décrire - l'espace rural rurbanisé". In: Ruralia, n. 9. 2001. 
THURMAN, Walter N. (1995). Assessing the environmental impact of farm policies. The AEI Press, Washington D.C.

TISSOT, Sylvie \& POUPEAU, Frank. (2005). L'espacialisatión des problèmes socials, In: Politiques des espaces urbain : penser, classer, admiistrer la pauvreté (1), Actes de la recherche en sciences sociales $n$. 159, editions du seuil, setembre 2005.

VECCHIATTI, Karin (2003). Desenvolvimento Territorial Rural: o diálogo entre sociedade, natureza e economia segundo Jane Jacobs. Dissertação de Mestrado, Procam/USP, 2003.

VEIGA, José Eli (1991). O desenvolvimento agrícola - uma visão histórica. São Paulo: Ed.Hucitec/Edusp.

VEIGA, José Eli (1994). Metamorfoses da política agrícola dos Estados Unidos. São Paulo: Annablume.

VEIGA, José Eli (1997). 'Crescimento, agricultura e meio-ambiente" IN: Anais do 25'. Encontro Nacional de Economia. Recife, Dezembro/1997, vol. 2, p. 900-939.

VEIGA, José Eli (1998). A face territorial do desenvolvimento. Relatório de pesquisa. Fapesp. São Paulo.

VEIGA, José Eli (2000). A face rural do desenvolvimento - natureza, território e agricultura. Porto Alegre: Ed. UFRGS.

VEIGA, JOSÉ Eli e colaboradores (2001). "O Brasil rural precisa de uma estratégia de desenvolvimento". Texto para Discussão n. 1. Brasília: Nead.

VEIGA, José Eli (2002). Cidades imaginárias: o Brasil é menos urbano do que se calcula. Campinas/sp: Autores Associados.

VEIGA, José Eli (2004). 'Destinos da ruralidade no processo de globalização'. Estudos Avançados, n. 51, maio-agosto 2004, p. 51-67.

VEIGA, José Eli (2005-a). Desenvolvimento sustentável - o desafio do século XXI. Rio de Janeiro: Garamond.

VEIGA, José Eli (2005-b). "Destinos da ruralidade - um 'zoom' sobre a Itália". Paper apresentado no XXIX Encontro Nacional da Anpocs, Caxambu-MG, Outubro/2005.

VEIGA, José Eli (2005-c). "Perspectivas e desafios do desenvolvimento rural sustentável no Brasil. Paper apresentado no Seminário Nacional de Desenvolvimento Rural Sustentável, CNDRS, Brasília/DF. 
VELASCO E CRUZ, Sebastião C. (2002). "Teoria e história - notas críticas sobre o tema da mudança institucional em Douglass North'. In: Primeira Versão, n. 107. Julho/2002. IFCH/Unicamp.

VELTZ, P. (2002). Des lieux et des liens. Paris: Ed. de l'aube.

YRUELA, Manuel P. et al. (2000). La nueva concepción del desarrollo rural - estudio de casos. CSIC/Instituto de Estudios Sociales Avanzados de Andalucia. Córdoba: 2000.

WANDERLEY, Maria de Nazareth B. (1998). "Raízes históricas do campesinato brasileiro'. In: TEDESCO, João Carlos - org. Agricultura familiar - realidades e perspectivas. Passo Fundo: Ed. UPF.

WANDERLEY, Maria de Nazareth B. (1999). "Territorialidade e ruralidade no nordeste: por um pacto social pelo desenvolvimento rural". Seminário Internacional Planejamento e Desenvolvimento Territorial. Campina Grande, Setembro/1999.

WANDERLEY, Maria de Nazareth B. (2000). "A emergência de uma nova ruralidade nas sociedades modernas avançadas; o "rural" como espaço singular e ator coletivo". Estudos sociedade e agricultura, n. 15, outubro. pp.87-145.

WANDERLEY, Maria de Nazareth B. (2001). Urbanização e ruralidade: relações entre a pequena cidade e o mundo rural - estudo preliminar sobre os pequenos municípios em Pernambuco. Recife: 2001.

WEBER, Max (1904/2004). A ética protestante e o "espírito” do capitalismo. São Paulo. Cia. Das Letras.

WEBER, Max (1974). “A objetividade nas ciências sociais’. In: Max Weber. Coleção Grandes cientistas sociais. São Paulo: Ática.

WEBER, Max (1998/2000). Economia e sociedade. Brasília: Ed. UnB. 2 vol.

WEID, Jean Marc von der (2001). “Qual estratégia para o desenvolvimento rural ?” . Nead. Série Textos para Discussão n. 2. Brasília/DF.

WILLIAMS, Raymond (1985). The city and the country. London: Hogarth Press.

WOOLCOCK, M. (1998). "Social capital and economic development - toward a theoretical synthesis and policy framework". Theory and society - Renewal and Critique in Social Theory, v. 27/2, 1998, p. 151-208.

ZANONI, Magda \& LAMARCHE, Hugues - coord. (2001). Agriculture et ruralité au Brésil - un autre modèle de développement. Paris: Éditions Karthala. 